\author{
Universidade de São Paulo \\ Faculdade de Filosofia, Letras e Ciências Humanas \\ Departamento de História \\ Programa de Pós-Graduação em História Econômica
}

Vinícius Moraes da Cunha

(Versão corrigida)

\title{
À procura da revolução brasileira: \\ itinerários do Movimento pela Emancipação do \\ Proletariado
}

São Paulo

2019 


\section{VINICIUS MORAES DA CUNHA}

À procura da revolução brasileira:

itinerários do Movimento pela Emancipação do Proletariado

Dissertação apresentado ao Programa de Pós-

Graduação em História Econômica do Departamento de História da Faculdade de

Filosofia, Letras e Ciências Humanas

da Universidade de São Paulo para obtenção do título de Mestre em História.

Orientador: Luiz Bernardo Pericás

(Versão Corrigida)

São Paulo

2019 
Autorizo a reprodução e divulgação total ou parcial deste trabalho, por qualquer meio convencional ou eletrônico, para fins de estudo e pesquisa, desde que citada a fonte.

Catalogação na Publicação

Serviço de Biblioteca e Documentação

Faculdade de Filosofia, Letras e Ciências Humanas da Universidade de São Paulo

Cunha, Vinicius Moraes da

À procura da revolução brasileira: itinerários do Movimento pela Emancipação do Proletariado / Vinicius Moraes da Cunha ; orientador Luiz Bernardo Pericás.

- São Paulo, 2019.

$203 \mathrm{f}$.

Dissertação (Mestrado) - Faculdade de Filosofia, Letras e Ciências Humanas da Universidade de São Paulo. Departamento de História. Área de concentração: História Econômica.

1. Revolução Brasileira. 2. Teoria da Dependência. 3. Jornal Companheiro. I. Pericás, Luiz Bernardo, orient. II. Título. 


\section{ENTREGA DO EXEMPLAR CORRIGIDO DA DISSERTAÇÃO/TESE}

\section{Termo de Ciência e Concordância do (a) orientador (a)}

Nome do (a) aluno (a): Vinícius Moraes da Cunha

Data da defesa:

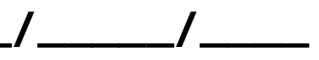

Nome do Prof. (a) orientador (a): Luiz Bernardo Pericás

Nos termos da legislação vigente, declaro ESTAR CIENTE do conteúdo deste EXEMPLAR CORRIGIDO elaborado em atenção às sugestões dos membros da comissão Julgadora na sessão de defesa do trabalho, manifestando-me plenamente favorável ao seu encaminhamento e publicação no Portal Digital de Teses da USP.

São Paulo, 4/9/2019.

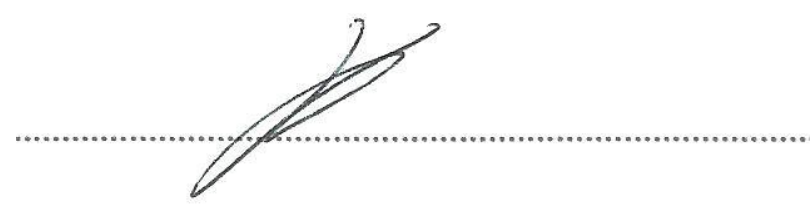


Nome: Vinicius Moraes da Cunha

Título: À procura da revolução brasileira: itinerários do Movimento pela Emancipação do Proletariado

Dissertação apresentado ao Programa de PósGraduação em História Econômica do Departamento de História da Faculdade de Filosofia, Letras e Ciências Humanas da Universidade de São Paulo para obtenção do título de Mestre em História.

Orientador: Luiz Bernardo Pericás

Banca examinadora

Prof. Dr.: Instituição:

Julgamento: Assinatura:

Prof. Dr.: Instituição: Julgamento: Assinatura:

Prof. Dr.: Instituição: Julgamento: Assinatura: 


\section{AGRADECIMENTOS}

Escrever uma dissertação nunca é fácil. Sobretudo se vivemos em tempos tão sombrios. Golpes, prisões arbitrárias, autoritarismo a céu aberto. Logo, a escrita desse texto foi feita com uma pena carregada de muitos sentimentos. Se consegui chegar ao final, devo a muitas mãos, abraços, camaradagem. Não somente durante o mestrado. Agradeço a minha mãe, Cristina, que batalhou demais na vida, me deu grande exemplo de determinação e sempre esteve ao meu lado quado precisei. A essa imagem de garra eu muitas vezes me apeguei. Agradeço a minha irmã querida, Mariana, quem possui singular carinho e empatia. Agradeço ao meu pai, Marcos, sempre grande exemplo de bondade e solidariedade, valores estes que são socialistas em suas essências.

Agradeço aos meus grandes amigos e amigas por andarmos juntos nas manifestações, nas trilhas de fim de ano e nos sambas.

Quero agradecer do fundo do meu coração a uma pessoa especial. Quem elevou a alto nível o significado da palavra companheirismo. Quem soube que o cuidado afetivo ultrapassa muitas camadas, momentos, noites em claro, dias de nervoso e dias de grandes expectativas. Carla Vitória, muito obrigado, minha companheira.

Quero destacar os membros que compuseram a banca examinadora dessa pesquisa de mestrado, a quem agradeço a leitura e observações feitas. A começar pelo professor Paulo Barsotti, da Fundação Getúlio Vargas, pelo professor Gilberto Maringoni, da Universidade Federal do ABC e do professor Osvaldo Coggiola, da Universidade de São Paulo. Como não poderia ser diferente, agradeço ao meu orientador Luiz Bernardo Pericás, que me acompanhou nesses longos e intensos anos.

Fundamental dizer que esse trabalho não seria possível sem o rigoroso trabalho arquivístico desempenhado por Carlos Henrique Menegozzo, o "Virtude", que reuniu e organizou a maior parte dos documentos utilizados nessa pesquisa, no 
Centro Sérgio Buarque de Holanda da Fundação Perseu Abramo.

Não poderia dimensionar a contribuição de Luiz Arnaldo, quem leu esse trabalho e deu sugestões muito ricas. A ele, e sua militância no MEP, meu agradecimento.

Agradeço também a Vera Colson, a primeira pessoa que leu a pesquisa, ainda não acabada, e também ajudou com contribuições fundamentais.

Imprescindível lembrar dos nomes das pessoas que, com os seus testemunhos, ajudaram a reconstruir a história do MEP. A Esther Kuperman, Inês Paes, Ivan Valente, Jorge Paes, Luiz Araújo, Maria Célia Fernandes, Miguel Carvalho e Nilton Santos, meus sinceros agradecimentos. A Nilson Penoni, agradeço pelo belo texto em que apresenta sua trajetória que se confunde com a história do MEP.

Por fim, dedico esse trabalho aos militantes do MEP, que ontem e ainda hoje não abriram mão da justiça, da liberdade, da democracia e do socialismo. A esses militantes, que suportaram os anos de chumbo, e não se curvaram, obrigado pelo exemplo. Não existe tempo ruim que não possa ser superado. Não há autoritarismo que nos vença. A força de nossas ideias reside no potencial de transformação da solidária empatia humana em projeto político. Isso me parece inabalável. 


\section{RESUMO}

Este presente trabalho tem o objetivo de reconstruir a história do Movimento pela Emancipação do Proletariado (MEP), organização política que compôs o segundo momento da chamada Nova Esquerda, em meados dos anos 1970. Fazendo parte do tronco que tem em sua raiz a POLOP (Política Operária), o MEP compartilhava da visão que defendia o caráter socialista da revolução brasileira, uma vez que o Brasil possuía uma economia plenamente capitalista, embora atrasada e dependente dos centros metropolitanos da economia-mundo. Do ponto de vista teórico, o MEP seguia as formulações da Teoria da Dependência e as contribuições de autores como Caio Prado Júnior, Moniz Bandeira, Florestan Fernandes e Chico de Oliveira, dentre outros, para encontrar uma teoria da Revolução Brasileira.

A partir dessas referências, a organização desenvolveu atuação clandestina contra a ditadura militar. Organizava-se com moldes no marxismo-leninismo e enxergava na classe operária o principal sujeito da revolução. Por fazer oposição ao regime, a organização foi vítima da máquina repressiva, sofrendo com prisões e tortura. O MEP desenvolveu atuação militante entre estudantes, professores, no meio operário e em bairros da periferia de grandes cidades e editou o jornal Companheiro. Além disso, atuou desde o início na fundação do Partido dos Trabalhadores. Em 1985, ao lado da Ala Vermelha do PCdoB e da Organização Comunista Democracia Proletária (OCDP), fundou o Movimento Comunista Revolucionário (MCR).

Palavras-chave: Revolução Brasileira; Teoria da- Dependência; MEP; POLOP; PCB; PT; jornal Companheiro. 


\section{ABSTRACT}

The present study aims to rebuild the story of Movimento pela Emancipação do Proletariado (Movement for the Emancipation of Proletariat - MEP), a political organization that integrated the second moment of the so called New Left, in the mid1970s. Stemming from POLOP (Política Operária), MEP shared a vision that advocated the socialist character of Brazilian Revolution, once the country had an enterely capitalist economy, albeit backward and depending on the metropolitan centers of the world economy. From a theoretical standpoint, MEP had followed the statements of Dependency Theory to develop a Brazilian Revolution theory based on the contributions of scholars like Caio Prado Júnior, Moniz Bandeira, Florestan Fernandes and Chico de Oliveira, among others.

From these referencies, the organization have developed a clandestine practice against the Military Dictatorship. Grounded on Marxist-Leninist principles, MEP considered the working class as the revolution protagonist. As opponents of the regimen, the organization members were victims of the repressive apparatus, suffering persecution and torture. MEP developed a militant work between students, teachers, the labor movement and on the outskirts of big cities and edited the Companheiro newspaper. Furthermore, MEP participated in the Workers Party (PT) foundation. In 1985, along with PCdoB red wing and the Organização Comunista Democracia Proletária (OCDP), founded the Movimento Comunista Revolucionário (MCR).

Keywords: Brazilian Revolution; Dependency Theory, MEP; POLOP, PCB, PT, Companheiro newspaper. 


\section{LISTA DE SIGLAS E ABREVIATURAS}

ADUSP - Associação dos Docentes da USP

$\mathrm{AEL}$ - Arquivo Edgard Leuenroth

ALA - Ala Vermelha

ALN - Aliança Libertadora Nacional

AP - Ação Popular

APEOESP - Associação dos Professores do Ensino Oficial do Estado de SP

APML - Ação Popular Marxista Leninista

CEBs - Comunidades Eclesiais de Base

CBA - Comitê Brasileiro pela Anistia

CEDEM - Centro de Documentação e Memória

CEPAL - Comissão Econômica para a América Latina e o Caribe

CEPEU - Comissão Pró-Entidade Única

CGD - Comissões Gerais de Investigação

CN - Comitê Nacional

CNA - Confederação da Agricultura e Pecuária

CNTE - Confederação Nacional dos Trabalhadores em Educação

COLINA - Comando de Libertação Nacional

CONCLAT - Conferência Nacional da Classes Trabalhadora

CPM - Código Penal Militar

CPPM - Código Processual Penal Militar 
CR - Comitê Regional

CSBH - Centro Sérgio Buarque de Holanda

CSN - Conselho de Segurança Nacional

CUT - Central Única dos Trabalhadores

DCE - Diretório Central dos Estudantes

DOI-CODI - Destacamento de Operações de Informação - Centro de Operações de Defesa Interna

DOPS - Departamento de Ordem Política e Social

DPPS - Departamento de Polícia Política e Social

ENE - Encontro Nacional de Estudantes

ENTOES - Encontro Nacional dos Trabalhadores em Oposição à Estrutura Sindical ESG - Escola Superior de Guerra

FAU - Faculdade de Arquitetura e Urbanismo

FB - Fração Bolchevique

FDLN - Frente Democrática de Libertação Nacional

FEB - Força Expedicionária Brasileira

FEPPEP - Federação Paraense dos Profissionais da Educação Pública

FIESP - Federação das Indústrias do Estado de São Paulo

FIRJAN - Federação das Indústrias do Estado do Rio de Janeiro

FRELIMO - Frente de Libertação de Moçambique

INPS - Instituto Nacional da Previdência Social 
IPM - Inquérito Policial Militar

ISEB - Instituto Superior de Estudos Brasileiros

JEC - Juventude Estudantil Católica

JUC - Juventude Universitária Católica

KPD-O - Kommunistische Partei Deutschland - Opposition

LIBELU - Liberdade e Luta

LOJM - Lei de Organização Judiciária Militar

MCR - Movimento Comunista Revolucionário

MDB - Movimento Democrático Brasileiro

MEP - Movimento pela Emancipação do Proletariado

MIR - Movimiento de Izquierda Revolucionaria

MR8 - Movimento Revolucionário 8 de Outubro

MOAP - Movimento de Oposição Aberta dos Professores

MPLA - Movimento Popular pela Libertação de Angola

MST - Movimento dos Trabalhadores Rurais Sem Terra

MUP - Movimento de União dos Professores

$\mathrm{NL}$ - Nova Luta

OBAN - Operação Bandeirantes

OCDP - Organização Comunista Democracia Proletária

OCML POLOP - Organização de Combate Marxista Leninista - Política Operária OPO - Organismo de Prática Orientada 
OPP - Organismo de Prática Partidária

ORM POLOP - Organização Revolucionária Marxista - Política Operária

PAIGC - Partido Africano de Independência da Guiné e Cabo

PCB - Partido Comunista Brasileiro

PCBR - Partido Comunista Brasileiro Revolucionário

PCdoB - Partido Comunista do Brasil

PCR - Partido Comunista Revolucionário

PDS - Partido Democrático Social

PMDB - Partido do Movimento Democrático Brasileiro

POC - Partido Operário Comunista

POR- Partido Operário Revolucionário

POUM - Partido Operário de Unificação Marxista

PSDB - Partido da Social-Democracia Brasileira

PSPB - Programa Socialista para o Brasil

PT - Partido dos Trabalhadores

PCUS - Partido Comunista da União Soviética

PUC - Pontifícia Universidade Católica

SE - Setor Estudantil

SI - Setor Interno

SO - Setor Operário

UDN - União Democrática Nacional 
UEE - União Estadual dos Estudantes

UERJ - Universidade Estadual do Rio de Janeiro

UFF - Universidade Federal Fluminense

UFRGS - Universidade Federal do Rio Grande do Sul

UFRJ - Universidade Federal do Rio de Janeiro

UNATE - União Nacional dos Trabalhadores em Educação

UNE - União Nacional dos Estudantes

UP - Unidade Popular

URSS - União das Repúblicas Socialistas Soviéticas

USP - Universidade de São Paulo

UTE/MG - União dos Trabalhadores do Ensino de Minas Gerais

VPR - Vanguarda Popular Revolucionária

Var-Palmares - Vanguarda Armada Revolucionária - Palmares 


\section{LISTA DE ILUSTRAÇÕES}

Ilustração 1: cartaz do Comitê Brasileiro pela Anistia. Pg. 189.

llustração 2: organograma das organizações de esquerda (feito com base no organograma apresentado no projeto Brasil Nunca Mais). Pg. 190.

llustração 3: exemplares do jornal Nova Luta. Pg. 191.

llustração 4: exemplares do jornal Companheiro. Pg. 192.

llustração 5: exemplares da revista Teoria e Prática. Pg. 193. 


\section{ÍNDICE}

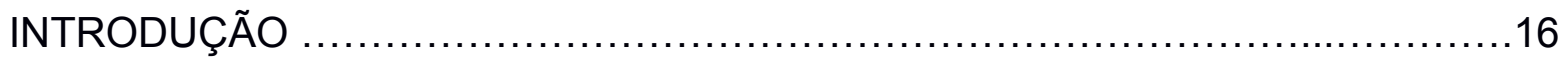

CAPÍTULO 1. UM PANORAMA DAS ESQUERDAS NOS ANOS $60 \ldots \ldots \ldots \ldots \ldots . . . . . .21$

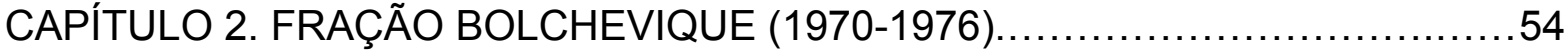

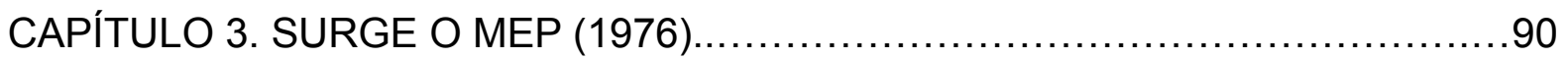

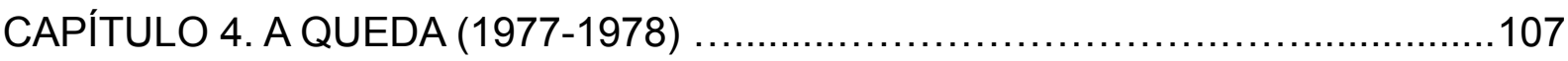

CAPÍTULO 5. CRESCIMENTO, NACIONALIZAÇÃO E A CHEGADA DO PT (1977-

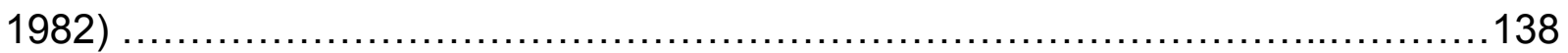

CAPÍTULO 6. DO II CONGRESSO AO MCR (1982-1985).............................172

CONCLUSÃO: À PROCURA DA REVOLUÇÃO BRASILEIRA...........................179

ANEXO: A ESTRATÉGIA ENCONTRA UMA SÍNTESE....................................183

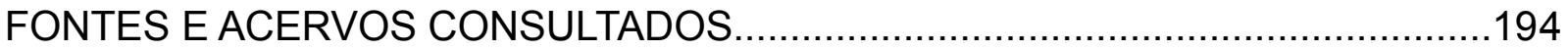

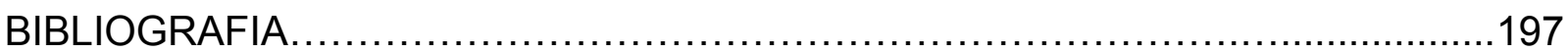




\section{INTRODUÇÃO}

As páginas que se seguem pretendem apresentar a história do Movimento pela Emancipação do Proletariado, organização política revolucionária surgida no ano de 1976. O interesse pelo grupo surge ao constatar que o MEP desempenhou papel político muito relevante. A começar pelo combate à ditadura militar, jornada dura marcada pela prisão, tortura, clandestinidade e exílio. O MEP, por outro lado, criou um sistema de pensamento particular, que em seu interior apresentava um amálgama composto por novas e velhas tradições da esquerda, teóricos até então pouco influentes e por experiências de participação social circunscritas ao contexto histórico.

Além desses aspectos, boa parte das organizações da esquerda brasileira foi pesquisada e analisada. O MEP não havia sido ainda objeto exclusivo de reflexão mais aprofundada, abordado apenas de maneira genérica ou tangenciado em estudos que tinham por foco outro objetivo. Assim, este trabalho vai em busca de contribuir com a historiografia, de modo a suprir uma brecha que merece ter seu legado registrado. Até que ponto a experiência coletiva da organização em questão somou para a esquerda nacional somente a reflexão acerca da trajetória poderá dizer, embora certamente os anos de atuação resistente do MEP ofereçam questões e suscitem problemas que reverberam em debates ainda contemporâneos.

A bagagem histórica construída pelo Movimento pela Emancipação do Proletariado foi carregada por militantes que a compartilharam em organizações posteriores: nos movimentos sociais, no Partido dos Trabalhadores, no Partido Socialismo e Liberdade, dentre outros. Se o passado é, como diz Hobsbawm ${ }^{1}$, uma dimensão permanente da consciência humana, componente das instituições, valores e padrões, para entender os grupos sociais acima citados, seus dilemas e contradições, cabe resgatar as rotas dos agentes coletivos que os construíram. É possível dizer que a trajetória de um grupo ou partido político carrega em si as contradições do tempo histórico.

1 Hobsbawm, Eric. Sobre História. Editora Companhia das Letras. São Paulo, 1997. Pg. 22. 
Como parte do passado da esquerda, ou seja, das forças políticas que compreendem os limites da sociedade capitalista e atuam para superá-la, o MEP aparece como um instrumento de análise do processo de transformações dessa mesma esquerda.

Lembrando novamente Hobsbawm:

[...] o passado continua a ser a ferramenta analítica mais útil para lidar com a mudança constante, mas em uma nova forma. Ele se converte na descoberta da história como um processo de mudança direcional, de desenvolvimento ou evolução. A mudança se torna, portanto, a sua própria legitimação, mas com isso ela se ancora em um "sentido do passado" transformado ${ }^{2}$.

O interesse aqui, portanto, é desvendar o MEP como parte do processo de configuração das diversas associações motivadas pela construção da verdadeira justiça, do sempre lembrado, mas ainda distante, mundo novo.

Nesse sentido, a ideia é constituir uma narrativa da história da organização. Apresentar sua origem, cuja raiz mais longínqua está na importante Organização Revolucionária Marxista - Política Operária (ORM-POLOP). Localizar suas formulações - como expressão da nova esquerda surgida após a derrota da luta armada - no interior do pensamento socialista vigente no país. Identificar as influências teóricas e os eventos históricos que marcaram seus posicionamentos. Apresentar suas práticas para além da descrição dessas, mas desvendar como a atuação concreta refletia em modo próprio de compreensão da disputa política. Enfim, dar relevo às marcas deixadas pelo MEP.

Cabe destacar aqui a sua atuação nos movimentos estudantil e sindical, na imprensa com seus periódicos editados, a denúncia do regime militar e o impacto da atuação da repressão sobre o grupo, os trabalhos de base em bairros periféricos, a participação na fundação do PT, enfim, como foi o processo de unificação com outras organizações políticas - a saber, fração da Ala Vermelha do PCdoB e a Organização Comunista Democracia Proletária (OCDP) - que culminou com a formação do 2 Idem. Pg. 30. 
Movimento Comunista Revolucionário (MCR), em 1985.

Embora este trabalho pretenda narrar a história do MEP, isso não implica em abstrair os problemas históricos que podem surgir ao analisar o desenvolvimento de uma organização política. O conflito entre narrativa de um lado e análise estrutural do outro não é o eixo motivador, mas, sim, como o que aconteceu pode dizer sobre algo.

O MEP surgiu em oposição à ditadura militar. Resgatá-lo necessariamente exige um retorno ao momento, em outras palavras, voltar a debater o próprio regime autoritário, revisitar a memória do período e a historiografia. A memória de ou sobre algo é sempre dinâmica. Desenvolve-se a partir de vetores sociais que a influenciam e buscam dar direções diversas aos fatos. Importante lembrar que a memória social tem ligação direta com a situação política.

No setor específico da vida política, a memória social pode estabelecer novos sentidos para as ações do passado, marcando identidades e espaços que atuam no jogo político do presente. História e memória se confundem e entram em choque ao falar sobre um mesmo passado, sobretudo quando há processos políticos que ainda estão em jogo e quando muitos dos protagonistas de ontem ainda estão vivos e atuantes ${ }^{3}$.

Resgatar a ditadura militar hoje possui significado ímpar. O passado, às vezes, se faz presente de maneira ardilosa. Conflitos antigos retornam. Narrativas oficiais ou que se tornam temporariamente hegemônicas são postas em xeque. Temas que no passado recente foram transformados em tabu voltam a ser parte da arena. Se o jogo político atual muda o prisma do olhar sobre a ditadura, também se transforma o modo de pensar a resistência.

$\mathrm{Na}$ época de atuação do MEP, o Brasil viveu tempos interessantes. Nesse mesmo período, a transição "lenta, gradual e segura" acelerou-se, sobretudo com a lei da Anistia, em 1979, e as eleições diretas para governador, em 1982. A organização acompanhou esse processo e sobre ele emitiu juízos. São comuns opiniões acerca da aliança com setores da burguesia nacional em torno das bandeiras democráticas. Os limites da anistia, com destaque para a impunidade dos agentes envolvidos na

3 Napolitano, Marcos. Recordar é vencer: as dinâmicas e vicissitudes da construção da memória sobre o regime militar brasileiro. In: Revista Antíteses. V.8, N 15ESP (2015). Pg. 10. 
máquina da repressão, e a Constituinte foram temas vastamente abordados. Sem contar o debate a respeito do papel que deveria exercer o Partido dos Trabalhadores e os desafios para a esquerda socialista em tempos de democracia.

Do ponto de vista metodológico, este trabalho buscou analisar a bibliografia sobre temas concernentes ao MEP, ou seja, a ditadura militar, as lutas de resistência, questões teóricas utilizadas para a compreensão e interpretação da realidade social brasileira, as raízes e troncos da esquerda.

Para além da bibliografia, foram analisados diversos documentos: resoluções congressuais, de encontros nacionais e regionais; periódicos publicados pelo grupo; textos formativos; autos judiciais produzidos pelos órgãos de repressão do Estado; e a própria imprensa comercial. Entrevistas com militantes e ex-militantes foram realizadas ao longo da pesquisa.

Como não havia nenhuma pesquisa substantiva sobre o Movimento pela Emancipação do Proletariado, esta pesquisa encontrou a dificuldade natural de desbravar um novo terreno. Certamente, disso resulta vários riscos, como omissões, seleção documental e de fatos que podem ser questionados, construção da narrativa histórica sujeita à críticas. De antemão, assumo os limites que poderão ser encontrados à frente. Importante frisar que este trabalho é uma tentativa de imersão na experiência do MEP. Desse modo, as leituras, opiniões, terminologias, polêmicas e análises contidas nas páginas a seguir são quase todas apresentadas pelo MEP através de seus documentos. Optei por "dar voz ao MEP”, sem necessariamente apresentar crítica externa ao contexto. Essa opção deriva do fato de não haver bibliografia com a qual se possa comparar a esta pesquisa. De todo modo, isso não implica na ausência de senso crítico, tampouco de busca pelo equilíbrio ao apresentar a história construída pela organização.

Essas palavras iniciais servem para orientar o rumo do trabalho a seguir. $A$ ideia é olhar para o MEP como um intelectual coletivo, observá-lo como um intérprete da realidade brasileira interessado na sua compreensão. O entendimento, todavia, por si só não basta, costumam dizer os interessados na mudança social. Dito isso, a 
trajetória do grupo será rastreada para que se entenda nas pegadas deixadas a reflexão política e social. "Teoria e prática" foi o nome de uma das publicações do MEP. Edifica um binômio, bastante conhecido, difícil de escapar. Intérprete rebelde. Intelectual orgânico. Assim o MEP será apresentado. 


\section{UM PANORAMA DAS ESQUERDAS NOS ANOS 60}

1960 e os anos que compuseram essa década foram marcados por grande efervescência na cena política do país. Mudanças aconteciam rapidamente. A posse de João Goulart, após a renúncia de Jânio Quadros, dada em sete de setembro de 1961, anunciava um cenário de crise e, no interior dessa, possibilidades de transformações sociais ${ }^{4}$.

A turbulência pela qual atravessava o país afetava a esquerda. Diferenças acerca da interpretação da realidade brasileira, as distintas visões dos caminhos aos quais seguir para construir o socialismo e o agravamento da situação com a violência da ditadura militar criaram as balizas que fizeram com que os interessados na transformação da realidade social se dividissem.

O Movimento pela Emancipação do Proletariado possui seu embrião gestado nesse período. Também na década de 1960, mais precisamente em 1961, surgiu a Organização Revolucionária Marxista-Política Operária, conhecida por POLOP, sendo essa a base do tronco que deu origem à tradição da esquerda brasileira da qual o MEP é oriundo.

Construir a história do MEP implica em resgatar também a história da POLOP e o contexto social que deu vazão à ramificação da esquerda marxista, até então hegemonizada pelo Partido Comunista. Vale dizer que o percurso traçado pelo velho Partidão desde os anos 50 elucida os desdobramentos da esquerda.

O PC cresceu e se fortaleceu após a Segunda Guerra Mundial. A derrota do eixo nazifascista foi obra, sobretudo, do esforço da União Soviética na guerra. O prestígio dessa vitória rendeu frutos aos partidos comunistas de todo o mundo. A breve legalidade, de 1945 a 1947, permitiu ao Partidão a eleição de 14 deputados e um senador da República, Luiz Carlos Prestes ${ }^{5}$. Nesse momento, a linha do partido,

4 Napolitano, Marcos. História do Regime Militar Brasileiro. São Paulo. Contexto, 2014. Pg. 18.

5 Vinhas, Moisés. O Partidão. A luta por um partido de massas (1922-1974). São Paulo. Hucitec, 1982. Pg. 88. 
em sintonia com a política externa da Rússia Soviética, era a defesa da paz, da estabilidade e do desenvolvimento das forças produtivas. A lógica da revolução por etapas guiava a estratégia, embora se pensasse à época que cabia à classe operária dirigir o processo de mudança. Primeiro, deveria ser feita a revolução democrática e nacional para que, em um segundo momento, a revolução socialista fosse levada adiante ${ }^{6}$.

De volta à ilegalidade, obra do governo do militar Eurico Gaspar Dutra, em pouco tempo é processada uma guinada na linha política. O partido radicaliza-se em meio à frustração por ter apostado na via legal. Do pacifismo migrou para a defesa da violência revolucionária, ao menos em teoria, ainda que sob a orientação da visão etapista ${ }^{7}$. Em primeiro de agosto- de 1950, Prestes apresenta um documento, em nome do Comitê Central, em que exprime a mudança. O documento em questão ficou conhecido como Manifesto de Agosto ${ }^{8}$. O IV Congresso, ocorrido em São Paulo, em novembro de 1954, reitera as bases programáticas do Manifesto. Ainda que sob a influência de paradigmas radicalizados, sofistica-se o papel da burguesia na revolução brasileira, conferindo a ela lugar na frente revolucionária. Havia o entendimento de que o Brasil vivia o risco iminente de recolonização, ameaça vinda do imperialismo norte-americano. Logo, a burguesia brasileira poderia ver seus interesses afetados, aceitando, assim, compor a frente da revolução nacional e democrática ${ }^{9}$.

No campo da política conjuntural, os comunistas passaram a fazer oposição ferrenha ao governo Vargas, caracterizado como de "traição nacional". Conclamavam

\footnotetext{
6 Moraes, João Quartim. Concepções comunistas do Brasil democrático: esperanças e crispações (1944-1954). In: Moraes, João Quartim (Org.). História do Marxismo no Brasil. Teorias. Interpretações, V3. Campinas. Unicamp, 1998.Pg. 224.

7 Gorender, Jacob. Combate nas trevas. São Paulo. Expressão Popular e Fundação Perseu Abramo, 2013. Pg. 24.

8 Vinhas, Moisés. O Partidão. A luta por um partido de massas (1922-1974). São Paulo. Hucitec, 1982. Pg. 140.

9 Santos, Raimundo. Crise e pensamento moderno no PCB dos anos 50. In: Moraes, João Quartim; Reis, Daniel Aarão (Org.). História do Marxismo no Brasil. Impacto das Revoluções, V1. Campinas. Unicamp, 2003. Pg. 200.
} 
a sua derrubada, além da sua substituição por outro governo, comandado pela Frente Democrática de Libertação Nacional (FDLN) ${ }^{10}$.

A oposição de direita a Vargas - que envolvia setores do Exército, da imprensa e a UDN de Carlos Lacerda - também conclamava pela queda do governo. Getúlio se suicida com um tiro no peito, em 24 de agosto, fato que promove verdadeira comoção popular. A política do PCB é confundida com o udenismo, o que gera séria crise no interior da legenda. Em Belo Horizonte e Porto Alegre, sedes dos jornais comunistas foram atacadas pela massa enfurecida ${ }^{11}$.

Uma das consequências desse choque foi a mudança de comportamento. Ainda que não dissesse, paulatinamente o PCB mudava de linha, como reconheceu o próprio Prestes ${ }^{12}$. PCB, após esse episódio, apoiou a chapa presidencial composta por Juscelino Kubitschek e João Goulart. Na ocasião, votava-se para presidente e vice separadamente. Em torno da movimentação, defendia-se que a chapa poderia incentivar o desenvolvimento das forças produtivas e selar a independência nacional frente ao imperialismo. Com vitória magra de JK por 0,5\% dos votos, muitos creditam o resultado ao apoio comunista ${ }^{13}$.

A questão das liberdades democráticas ganhou relevo, uma luta que, ao mesmo tempo, ajudava a criar melhores condições políticas para a atuação do PCB e estimulava a participação das massas. Essa percepção advinha mais de um imperativo prático que através de uma guinada teórica dos comunistas.

Se, no Brasil, a turbulência nacional mostrava seus efeitos no interior do Partidão, o XX Congresso do Partido Comunista da União Soviética (PCUS) promoveu, por sua vez, outra enorme reviravolta. Nikita Krushev denunciou os crimes

10 Idem. Pg. 201.

11 Gorender, Jacob. Combate nas trevas. São Paulo. Expressão Popular e Fundação Perseu Abramo, 2013. Pg. 25.

12 Moraes, Dênis. A esquerda e o golpe de 1964. Expressão Popular. São Paulo, 2014. Pg. 60.

13 Moraes, João Quartim. Concepções comunistas do Brasil democrático: esperanças e crispações (1944-1954). In: Moraes, João Quartim (Org.). História do Marxismo no Brasil. Teorias. Interpretações, V3. Campinas. Unicamp, 1998. Pg. 236. Ver também: https://cpdoc.fgv.br/producao/dossies/JK/artigos/JkRumoPresidencia/Candidatura. 
cometidos por Josef Stalin. Havia um culto de sua personalidade no PCB. Seus métodos organizativos e a visão estratégica dual do processo revolucionário eram marcadamente stalinistas. Logo, a identidade partidária entrou em redemoinho diante das denúncias ${ }^{14}$.

Frente à crise no interior, três linhas distintas se abrem no partido. A considerada revisionista, com Prestes à frente, se alinhava à URSS, aceitando o relatório de Nikita Krushev. Outra, chamada stalinista, denunciava os revisionistas e se mantinha fiel à obra de Stalin. A terceira era comandada pelo capitão Agildo Barata, que fazia críticas ao funcionamento do PCB. Agildo logo saiu do partido. A corrente stalinista, liderada por João Amazonas, Maurício Grabois e Pedro Pomar, em 1962, fundou o PCdoB ${ }^{15}$.

Esses elementos como um todo compuseram a porta de entrada da chamada nova esquerda. A hegemonia do Partidão passou a ser questionada como nunca antes havia acontecido, tanto em relação à capacidade de direção do partido, quanto às suas visões teóricas.

\subsection{Nova esquerda}

É possível entender a formação da chamada nova esquerda através do conjunto de organizações que, no campo do marxismo, surge a partir do início dos anos 1960 como alternativas ao PCB e dispostas a dirigir as lutas sociais em direção socialista. Seus principais troncos são o PCdoB, a AP, as chamadas dissidências do PCB, o trotskismo e a POLOP ${ }^{16}$.

14 Santos, Raimundo. Crise e pensamento moderno no PCB dos anos 50. In: Moraes, João Quartim; Reis, Daniel Aarão (Org.). História do Marxismo no Brasil. Impacto das Revoluções, V1. Campinas. Unicamp, 2003. Pg. 205.

15 Gorender, Jacob. Combate nas trevas. São Paulo. Expressão Popular e Fundação Perseu Abramo, 2013. Pgs. 40-41.

16 Reis Filho e Ferreira de Sá. Imagens da Revolução. Documentos Políticos das organizações Clandestinas de esquerda dos anos 1961-1971. São Paulo. Expressão Popular, 2006. Pg. 15-16. 
Os stalinistas do PCdoB criticaram o núcleo dirigente do PC por suposto abandono do marxismo. Em 1961, em nome de Prestes e da direção majoritária, o semanário do partido, Novos Rumos, publica programa e estatuto com a finalidade de buscar no Tribunal Superior Eleitoral a legalização. A novidade embutida vinha no nome: o Partido Comunista do Brasil passou a ser Partido Comunista Brasileiro. Com a mudança, esperava-se que um dos argumentos pela cassação da legenda - o fato de não ser um partido nacional, mas a seção brasileira da Internacional Comunista caísse por terra. A manobra não foi suficiente para vencer a ilegalidade ${ }^{17}$.

Amazonas, Grabois e Pomar, ao lado de uma centena de militantes, reuniriam a Conferência Nacional Extraordinária do Partido Comunista do Brasil, em fevereiro de 1962. Começa aí a história do PCdoB. Nessa ocasião, defendiam as teses do IV Congresso do PCB, ou seja, o etapismo. Entendiam também que somente através da revolução armada poderia ser possível alcançar o governo revolucionário.

No contexto das toadas dissidentes, outras organizações de esquerda aparecem com destaque na cena política. A Ação Popular, de origem no catolicismo, é uma delas. Popularmente conhecida por AP, o grupo teve muitos de seus quadros vindos da Juventude Universitária Católica (JUC) e da Juventude Estudantil Católica (JEC). A organização possuía, de algum modo, uma visão ideológica própria, que fazia confluir socialismo e humanismo ${ }^{18}$. Sua presença no movimento estudantil era muito marcante, sendo de seus quadros vários presidentes da União Nacional dos Estudantes (UNE). Um deles foi Luís Travassos, quem presidiu a entidade no turbulento ano de 1968. O padre Henrique Vaz foi o principal ideólogo. Os deputados Almino Afonso e Paulo de Tarso compunham, por seus turnos, os quadros de apoiadores. A Revolução Chinesa exerceu muita influência política nas formulações da AP. Noções como a de guerra popular prolongada, a valorização do trabalho camponês e a proletarização da militância, ou seja, destacar militantes para exercer trabalhos proletarizados, faziam parte de seu horizonte político. Com a radicalização

17 Vinhas, Moisés. O Partidão. A luta por um partido de massas (1922-1974). São Paulo. Hucitec, 1982. Pg. 177.

18 Gorender, Jacob. Combate nas trevas. São Paulo. Expressão Popular e Fundação Perseu Abramo, 2013. Pgs. 42-43. 
da ditadura, posteriormente, a AP viu parte de seus membros aderir à luta armada, criando a Ação Popular Marxista Leninista (APML) ${ }^{19}$.

O trotskismo tinha como força mais destacada o Partido Operário Revolucionário (POR), o qual era filiado à IV Internacional liderada por Posadas ${ }^{20}$. $\mathrm{O}$ ponto a ser destacado é que o POR, de acordo com a linha de sua internacional, via na luta nacionalista um caminho para a revolução, de modo que, no Brasil, buscavam se relacionar com setores ligados ao nacionalismo revolucionário de influência de Leonel Brizola. Havia alguma presença no movimento estudantil, com a organização Movimento Estudantil $1^{\circ}$ de Maio, a qual posteriormente tornou-se Organização Comunista $1^{\circ}$ de Maio.

Do tronco do PCB, surgiram as dissidências. Quase todas elas vieram a ser militaristas. Questionavam a letargia do Partidão e discordavam da maneira como se deveria fazer oposição à ditadura militar. Nesse campo, a dissidência de São Paulo tornou-se a Ação Libertadora Nacional ${ }^{21}$. Comanda por Carlos Marighella e Joaquim Câmara Ferreira, a ALN propunha a luta armada como forma de resistência e caminho para a revolução. Muito inspirada na Revolução Cubana, defendiam a ideia do foco revolucionário de Che Guevara e Debray. Através da criação de vários focos, vislumbrando a maneira como se processou na Sierra Maestra, poderia se formar um grande exército popular, que derrubaria a ditadura, colocando em seu lugar um governo de libertação nacional. Esses combatentes entendiam que a "ação faz a vanguarda" e que "o papel do revolucionário é fazer a revolução". Passaram a negar a necessidade do partido da revolução, se distanciando de um dogma do movimento comunista internacional.

Sugerindo outra alternativa, Jacob Gorender, Mário Alves e Apolônio de Carvalho foram os principais dirigentes que construíram o Partido Comunista 19 Reis Filho e Ferreira de Sá. Imagens da Revolução. Documentos Políticos das organizações Clandestinas de esquerda dos anos 1961-1971. São Paulo. Expressão Popular, 2006. Pg.371.

20 Silva, Antonio Ozai da. História das tendências no Brasil: origens, cisões e propostas. São Paulo. DAG, 1986. Pgs. 134-135.

21 Gorender, Jacob. Combate nas trevas. São Paulo. Expressão Popular e Fundação Perseu Abramo, 2013. Pg. 105. 
Brasileiro Revolucionário $(\mathrm{PCBR})^{22}$. Compartilhavam de críticas semelhantes às da ALN em relação ao PCB. Buscaram, inclusive, elaborar algo em comum com Marighella. No entanto, os dirigentes do PCBR mantinham a conviç̧ão da necessidade da forma partido para a revolução.

Outra dissidência muito destacada foi a da Guanabara, posteriormente conhecida por MR-8. Dos seus feitos, encontra-se o sequestro de embaixador norteamericano, Charles Elbrick, em 1968, ação realizada em parceria com a ALN. Do Rio Grande do Sul, a dissidência juntou-se com a POLOP, dando origem ao POC (Partido Operário Comunista). Em crise interna baseada na diferença da forma de luta de resistência à ditadura, o POC logo racha, sendo que uma das partes volta a ser POLOP, mas dessa vez Organização de Combate Marxista Leninista - Política Operária (OCML-POLOP).

As organizações aqui citadas são as mais conhecidas, mas certamente não as únicas. Aqui nos interessa mais um panorama geral, com destaque para a POLOP (Política Operária e a defesa do caráter socialista da revolução). A Organização Marxista Revolucionária - Política Operária (ORM-POLOP) surgiu durante encontro realizado em Jundiaí, no interior de São Paulo, em princípios de 1961. Formada, sobretudo, em meios intelectualizados, a POLOP deixou seu registro histórico, em especial, através da leitura que legou da formação da realidade brasileira e, com base nesta, na elaboração sobre o caráter da revolução almejada.

Militantes e intelectuais valorosos compuseram a organização marxista. Eric Sachs (mais conhecido pelo pseudônimo de Ernesto Martins), Michael Löwy, Vânia Bambirra, Theotônio dos Santos, Emir Sader, Eder Sader, Juarez Guimarães, Ruy Mauro Marini e Moniz Bandeira são alguns ${ }^{23}$.

Os fundadores da POLOP vieram da Juventude Socialista da Guanabara,

22 Idem. Pg. 113.

23 Mattos, Marcelo Badaró. Em busca da revolução socialista. A trajetória da POLOP (1961-1967). In: Ridenti, Marcelo; Reis Filho, Daniel Aarão (org.). História do Marxismo no Brasil - partidos e organizações dos anos 1920 aos 1960, V 5. Campinas. Unicamp, 2002. Pg. 197. 
alguns membros da Liga Socialista, outros do PSB, e também da Juventude Trabalhista. Buscavam encontrar seus fundamentos teóricos em Rosa Luxemburgo, Talheimer, Brandler, Trotsky e Bukhárin. Um dos principais traços da identidade polopista era justamente o anti-stalinismo arraigado. Tal característica justifica a postura crítica ao PCB ou, utilizando a ordem contrária dos fatores, as análises dos limites do Partidão desdobravam-se na compreensão anti-stalinista.

Vale a pena destacar um aspecto internacionalista, cujo vínculo foi estabelecido por Eric Sachs ${ }^{24}$. Austríaco radicado no Brasil, ele reivindicava o KPD-O, dissidência do Partido Comunista Alemão, cujos principais dirigentes eram Brandler e Talheimer. Esta tendência do marxismo internacional, a grosso modo, embora compreendesse as deformações dos Estados Operários, os defendia frente ao imperialismo. Ao mesmo tempo, buscava certa independência política e teórica. Bebiam da experiência de Rosa Luxemburgo e Karl Liebkecht ${ }^{25}$. Em uma conversa com Luiz Arnaldo, Michel Löwy comentou que o nome Política Operária era uma homenagem ao periódico editado pelo KPD-O Politsches Arbeit, cuja tradução literal nomeou a organização brasileira ${ }^{26}$. Desta tradição internacional o MEP passou a fazer parte. Outras referências internacionais que foram assumidas também pelo MEP foram o POUM (Partido Operário de Unificação Marxista), que atuou na Espanha no contexto da guerra civil de 1936, a Revolução Cubana e o MIR Chileno ${ }^{27}$.

As visões acerca da POLOP, no entanto, variam. As ênfases são dadas a partir de critérios e escolhas variados. Jacob Gorender, por exemplo, reconhece o vigor

24 Há uma polêmica na historiografia a respeito da trajetória de Eric Sachs, também conhecido como Ernesto Martins. Victor Meyer escreveu uma nota biográfica sobre Eric, publicada pelo Centro de Estudos Victor Meyer (http://centrovictormeyer.org.br/wp-content/uploads/2016/12/EricoSachs miolo_pro-site.pdf. Pg. 21). Nela, consta que Ernesto Martins atuou diretamente com Talheimer e Brandler, sendo o responsável por trazer a experiência do KPD para o Brasil. Todavia, Moniz Bandeira, em Notas sobre a POLOP e Eric Sachs, questiona veemente essa versão. Diz que há erros factuais na nota biográfica, como o contato direto entre Sachs, em sua juventude, com os líderes do KDP. Reconhece a importância intelectual de Sachs, embora afirme que as influências da POLOP estavam mais em Rosa Luxemburgo e Trotsky que em Talheimer e Brandler. Diz também que Sachs não foi o pioneiro na formulação da visão socialista da revolução brasileira, ainda que tenha dado significativas contribuições.

25 Bandeira, Luiz Alberto Moniz. Notas sobre a POLOP e Eric Sachs. Revista Espaço Acadêmico - N. 188 - janeiro/2017. ISSN 1519.6186.

26 Contribuição enviada por escrito por Luiz Arnaldo em 05 de maio.

27 Idem. 
intelectual da organização, em especial de alguns de seus membros, ainda que destaque a incapacidade destes marxistas de exercerem capacidade de inserção real na luta dos trabalhadores ${ }^{28}$. Um sintoma do isolamento revela-se com a postura altamente crítica da POLOP em relação ao governo João Goulart e às reformas de base dos anos 1960. As ruas das cidades e o campo, com as ligas camponesas ${ }^{29}$, reivindicavam direitos trabalhistas, as reformas agrária, urbana, educacional, o controle da remessa de lucro, enfim, pautas que compunham as reformas de base. $O$ ponto auge desse entusiasmo social foi o famoso comício do dia 13 de março, na Central do Brasil, no centro do Rio de Janeiro. A POLOP ficou à margem desse movimento, enquanto o trabalhismo e o Partido Comunista viviam momento de bastante influência.

Observando por outras vias, os historiadores Daniel Aarão Reis Filho e Marcelo Badaró conferem à POLOP leitura mais positiva, destacando o já citado desempenho intelectual. Daniel Aarão dedica à fundação da POLOP, em 1961, o marco do surgimento da nova esquerda, visto que esta foi a primeira organização a se postular como possível substituta do PCB no campo da hegemonia dos movimentos de resistência.

Badaró explora a composição social dos quadros militantes da Política Operária $^{30}$. Como era comum na maioria das organizações marxistas da época, boa parte vinha de setores médios da sociedade. Baseados nos dados do Projeto Brasil Nunca Mais ${ }^{31}$, o qual fez um levantamento dos processados por organização, viu-se que dos 80 militantes alvos de um Inquérito Policial Militar, 26,2\% eram estudantes,

28 Gorender, Jacob. Combate nas trevas. São Paulo. Expressão Popular e Fundação Perseu Abramo, 2013. Pg. 42.

29 Vale dizer que a POLOP nutriu relações com as Ligas Camponesas, assim como o PCdoB e a AP. As Ligas tiveram muita relevância política, sobretudo no nordeste. Seu principal líder era Francisco Julião, quem aderiu de corpo e alma ao ideário construído em torno da Revolução Cubana. Com a palavra de ordem "reforma agrária na lei ou na marra", as Ligas radicalizaram, tendo preparado núcleos guerrilheiros. A iniciativa armada foi debelada pelo exército em 1962. Ver Moraes, Dênis. $A$ esquerda e o golpe de 1964. Expressão Popular. São Paulo, 2014. Pg. 90.

30 Mattos, Marcelo Badaró. Em busca da revolução socialista. A trajetória da POLOP (1961-1967). In: Ridenti, Marcelo; Reis Filho, Daniel Aarão (org.). História do Marxismo no Brasil - partidos e organizações dos anos 1920 aos 1960, V 5. Campinas. Unicamp, 2002. Pg. 200.

31 Disponível em: http://bnmdigital.mpf.mp.br/pt-br/ 
2,5\% artistas, 3,7\% empregados, 1,3\% empresários, 13,8\% professores, $15,5 \%$ profissionais liberais, dentre outras classificações. Vale destacar ainda dois grupos. Somente 3,7\% eram trabalhadores manuais urbanos. Consta aqui uma contradição. Talvez uma ironia. A POLOP possuía um forte traço obreirista. Suas ideias eram herdeiras fiéis do processo revolucionário de Outubro de 1917, na Rússia, de tal forma que enxergava a classe operária como portadora da tarefa histórica de comandar a redenção da humanidade. Justamente esta classe faltava à organização, em comparação ao que os próprios desejavam. Tal realidade, no entanto, estava longe de ser exclusiva da POLOP. Parte dessa situação pode ser explicada pela severa repressão que logo se abateu nos sindicatos e no conjunto dos movimentos sociais, com prisões e intervenções por parte do Estado.

Outro dado interessante a respeito da composição da POLOP é a quantidade expressiva de militares de baixa patente, que alcançava $20 \%$. Os militantes polopistas buscavam se associar aos movimentos de militares. Viam na figura de Leonel Brizola um aliado. Chegaram a participar de um ensaio de luta armada, ao lado do Movimento Nacionalista Revolucionário, conhecido por Guerrilha de Copacabana. $\mathrm{O}$ Cenimar (Centro de Inteligência da Marinha) desbaratou o plano ainda durante sua fase elaboração. Mais para frente, A POLOP tomou parte da criação da Guerrilha do Caparaó, que, embora saída do papel, não logrou muitos frutos ${ }^{32}$.

Em 1963, ocorreu o seu II Congresso. Das linhas tiradas, encontrava-se a formação de uma frente dos trabalhadores da cidade e do campo. Tal frente se diferenciava daquela proposta pelo Partido Comunista, na medida em que não aceitava setores da chamada burguesia nacional.

No movimento estudantil, a POLOP chegou a ter um grau maior de destaque. Participavam de fóruns da UNE, tinham representação na direção da entidade e chegaram a dirigir alguns centros acadêmicos. Entendiam que o movimento dos estudantes poderia contribuir com o processo revolucionário dos trabalhadores a organizações dos anos 1920 aos 1960, V 5. Campinas. Unicamp, 2002. Pgs. 207-208. 
partir de agitações que desestabilizassem o regime, além de ser uma espécie de manancial de quadros ${ }^{33}$.

Por ser contrária às reformas de base e crítica ao governo de Jango, a POLOP só não se via em isolamento maior em razão da proximidade com os movimentos de militares. Essa proximidade, lembrando Badaró, relacionava-se ao modelo revolucionário defendido, inspirado na Revolução de Outubro e, nessa mesma toada, na construção de sovietes de operários e soldados. Além disso, identificavam na figura de Leonel Brizola alguém disposto a fazer no Brasil algo semelhante à Revolução Cubana.

Assim, Theotônio dos Santos comenta, ao ser perguntado por Dênis de Moraes sobre Brizola e Arraes ${ }^{34}$

"Era a divisão entre a linha nacional-democrática e uma linha mais avançada, que Brizola já expressava. Brizola estava mais inspirado na Revolução Cubana do que numa perspectiva nacional-democrática".

\subsection{Encontros e desencontros}

Na miríade da esquerda, alguns temas organizavam as diferenças políticas. Marcelo Ridenti identifica as divergências e convergências dos projetos revolucionários a partir de três grandes campos, sendo eles o tipo de organização necessária para o enfrentamento político, as formas de luta adequadas para estabelecer o equilíbrio entre estratégia e tática e, por fim, o caráter da revolução ${ }^{35}$.

A esquerda marxista, formada na tradição comunista ou inspirada na Revolução de Outubro, trazia consigo de maneira muito arraigada a noção leninista de partido. No resumo da ópera, para operar a superação do capital, se fazia necessário um partido centralizado, altamente disciplinado, apto para as tarefas legais e ilegais, com forte enraizamento na classe operária e com condições de dirigir

33 Idem. Pg. 206.

34 Moraes, Dênis. A esquerda e o golpe de 1964. Expressão Popular. São Paulo, 2014. Pg. 340.

35 Ridenti, Marcelo. O fantasma da revolução brasileira. São Paulo. UNESP, 2010. Pg. 32. 
o conjunto das lutas das classes que não podiam ver seus interesses plenos em marcos capitalistas. De acordo com essa tradição, deveria haver um único partido, que carregasse em seu âmago as aspirações da classe operária. O partido seria uma espécie de ente histórico, portador da mais difícil responsabilidade humana: emancipar os explorados das correntes da servidão imposta pela contradição capital/trabalho.

O PCB era a principal força herdeira desse legado. E, ao lado das formulações leninistas acerca do papel do partido, somava-se o peso do legado stalinista, que consagrava ainda mais a noção de partido único, fiel à Pátria dos Povos.

O aparecimento das novas organizações, que se colocavam no campo do marxismo e ao mesmo tempo se arvoravam à condição de direção política do operariado, abriu espaço para o questionamento da canônica formulação do partido único da vanguarda. A unicidade partidária do PCB foi posta em risco. Novos atores queriam assumir o seu lugar, ainda que não sozinhos. Dessa ruptura, outros arranjos de organização apareceram, combinando elementos da tradição marxista-leninista e sugestões novas advindas das lutas da época.

Várias organizações preservaram o modelo leninista - algumas tiveram maior sucesso na prática, outras, somente nas letras das resoluções de tática e estratégica. O PCdoB, o PCBR, a VPR, a AP, o COLINA e a POLOP são exemplos de grupos que preservavam a defesa do partido leninista ${ }^{36}$. Outros agrupamentos, no entanto, radicalizaram a crítica. Enxergavam que a estrutura partidária, ao invés de auxiliar a ação prática, tornava a ação dos revolucionários presa no interior de suas próprias fileiras, vivendo em um microcosmo que não correspondia mais às tarefas gerais. $A$ ALN, em especial, achava que a vanguarda deveria se fazer pela prática. As reuniões infindáveis, as polêmicas estéreis, o apego à burocracia tão somente atrapalhavam ${ }^{37}$. Estava na hora, pensavam eles, de experimentar a luta em si, de modo a construir um laboratório-escola da vanguarda revolucionária.

36 Idem. Pg. 39.

37 Ibidem. Pg. 41. 
Alguns agrupamentos adeptos da luta armada - sobretudo quanto à guerrilha rural - apresentavam a solução que valorizava o foco ou a luta no campo, embora entendessem que as ações militares deveriam estar subordinas à direção do partido. PCdoB e PCBR interpretavam dessa forma.

Com o decorrer dos fatos, no entanto, percebia-se que o conjunto das forças militaristas apresentava um modelo organizativo próximo, fincado numa tríade assim composta por um grupo de trabalho armado, outro responsável pelas bases trabalhadoras e, por fim, um terceiro encarregado da relação com os setores médios da sociedade, responsável também pelo apoio logístico.

Não seria um exagero dizer que a Revolução Cubana foi a experiência recente, para a época, que mais contribuiu para abalar a crença no padrão marxistaleninista de partido. Um grupo de jovens que cruza do México para Cuba - a poucas léguas do imperialismo norte-americano -, instaura-se nas sierras e, em não muito tempo, consegue ganhar o apoio de boa parte do campesinato e das massas efervescentes de Havana. $O$ enredo, encantador e bem-sucedido, torna-se uma inspiração.

Mas é verdade que outras experiências compunham o imaginário da guerrilha, como as batalhas nacionais travadas pelos povos africanos por independência e o fracasso militar yankee no Vietnã. Vale lembrar que a vitória comunista na China, liderada por Mao Tse Tung, em 1949, teve dimensão crucial na influência das esquerdas. Em todos esses exemplos, nacionalismo e socialismo parecem caminhar juntos no mesmo projeto.

Fidel Castro dizia que o papel do revolucionário é fazer a revolução. Marighella reproduzia essas palavras por aqui ${ }^{38}$. Um grupo coeso, ainda que pequeno, mas dedicado e destemido poderia pela prática abalar as estruturas do Estado burguês, para que em um movimento contínuo ganhasse dimensão massiva e, do mesmo modo que os cubanos cercaram Havana, poderia cercar outros núcleos urbanos.

38 Ver o texto de Carlos Marighella "Sobre a organização dos revolucionários", de outubro de 1969: https://www.marxists.org/portugues/marighella/1969/08/sobre.htm. 
Nesse ponto, a respeito da forma de organização, fica como síntese: havia os grupos que entendiam a necessidade do partido e os que achavam que o partido poderia ser suplantado.

Para além disso, em relação à luta armada, algumas organizações defendiam que as ações militarizadas deveriam estar no contexto da ação partidária. Há exemplos de outras forças políticas adeptas da luta armada que não consideravam imprescindível estar na órbita de mando de algum partido, como as Ligas Camponesas e o Movimento Nacionalista Revolucionário, ligado a Leonel Brizola. Todavia, essas duas organizações fogem ao campo da nova esquerda, uma vez que não se alinhavam diretamente com a tradição marxista.

A análise acerca do caráter da revolução e a compreensão do tipo de organização necessária exerciam rupturas e aproximações. No entanto, a forma de luta a ser empregada no momento compreendia uma linha divisória mais nítida e segmentava a esquerda por nichos ${ }^{39}$.

A polarização política e social tensionava o conjunto da esquerda. $O$ fechamento do regime, a censura, a repressão às manifestações de rua, o cerco aos sindicatos, a tortura, enfim, o exercício do poder pela coerção disparou em largos setores a ideia da luta armada.

Impedidos de agir publicamente, o enfrentamento às escuras, nas vielas ou nos rincões do país, despertava como um imperativo moral para os revolucionários. Antes da análise objetiva das condições reais, vinha a convicção, o dever de fazer algo. Caberia construir as tão chamadas condições favoráveis para a revolução através da imposição da própria vontade revolucionária. A revolução faltaria ao encontro, como lembra Daniel Aarão ${ }^{40}$. Os revolucionários, todavia, não furaram na

39 Ridenti, Marcelo. O fantasma da revolução brasileira. São Paulo. UNESP, 2010. Pg. 46.

40 A famosa expressão de Daniel Aarão Reis foi apresentada no livro A Revolução faltou ao encontro - os comunistas no Brasil, publicado em 1990 pela Editora Brasiliense. A expressão, que aparece em muitos textos de Daniel Aarão, representa a empreitada frustrada da esquerda revolucionária durante a ditadura. O autor parte da ideia de que a esquerda apostava na utopia do impasse, ou seja, as contradições da ditadura e da própria sociedade de classes geraria uma condição-limite, a partir da 
hora marcada.

É interessante notar que praticamente todas as organizações marxistas adotaram a premissa da luta armada. Umas somente no campo da teoria. Outras conseguiram aplicar na prática ensaios dessa forma de luta. ALN, VPR, VAR, ALA, PCdoB, AP, COLINA, PCBR, MR-8 e POC são as principais delas ${ }^{41}$.

O que diferenciava esses grupos era a maneira como se deveria construir a luta armada. Todos, em princípio, advogavam a tese da centralidade da luta no campo. A guerrilha urbana serviria como fonte de recursos, sabotagem das forças adversárias e propaganda revolucionária.

O PCdoB e a AP, de influência maoísta, eram adeptos da "guerra popular revolucionária" e do "cerco da cidade pelo campo". O PCdoB foi a organização que mais logrou sucesso na prática, dedicando-se à construção da Guerrilha do Araguaia, deflagrada em 1972. O partido abriu mão de ações urbanas, o que ajudou a não atrair os radares da repressão. O exército brasileiro levou alguns meses para conseguir debelar por completo os guerrilheiros. A Ala Vermelha também compartilhava da valorização do trabalho no campo, ainda que não abrisse mão da violência nas cidades como forma de desestabilizar o regime.

A noção de "foco revolucionário", proposta por Che Guevara e desenvolvida por Régis Debray em $A$ revolução na Revolução ${ }^{42}$, impunha uma tônica, uma espécie de guia. A ALN de Marighella se orientava nessa direção, ainda que suas ações tenham se restringido aos centros urbanos, através de assaltos, ocupação de rádios, defesa armada de frentes de luta públicas, como manifestações ou cenário de conflito aberto. Um exemplo disso foi a guerra entre estudantes da Faculdade de Filosofia da USP com estudantes do Mackenzie, na rua Maria Antônia, em 1968, quando os guerrilheiros da ALN cederam armas e militantes para defender os membros do

qual seria a hora e a vez dos socialistas.

41 Ridenti, Marcelo. O fantasma da revolução brasileira. São Paulo. UNESP, 2010. Pg. 46.

42 Debray, Regis. Revolução na Revolução. São Paulo. Centro Editorial Latino Americano, 1985. 
movimento estudantil contra os ataques do Comando de Caça aos Comunistas ${ }^{43}$. Ações como essa abriam espaço para o recrutamento de novos membros. Sequestro de embaixadores foi uma ferramenta muito utilizada para liberar presos políticos. Charles Elbrick, embaixador americano, sequestrado por um comando da DI-GB (posterior MR-8) com a ALN, foi trocado por 18 presos políticos, fato que causou enorme furor na sociedade, além de ter criado o sentimento entre os revolucionários de que o caminho da vitória poderia ser traçado na ponta do fuzil. Outros diplomatas foram também sequestrados - um alemão, um japonês e um suíço - levando à soltura 115 presos $^{44}$.

Muito se pensava que, dado o atraso da formação do capitalismo no Brasil, o elo frágil da dominação de classes se encontrava no interior do país. Nisso residia uma explicação teórica da luta do campo. O PCdoB e a ALA se aproximavam do POC e da VPR nesse ponto de vista por caminhos distintos. Os primeiros enxergavam resquícios feudais no campo, ao passo que os segundos o entendiam como elo frágil, tal qual a leitura apresentada na teoria da dependência de Gunder Frank ${ }^{45}$. Segundo essa, mesmo no interior de países capitalistas, havia ralações de dependência entre regiões mais ou menos desenvolvidas.

O PCB foi a principal organização que não aceitou esse modelo da luta armada. Considerava uma aventura política, dada a falta de correlação de forças. Correntes trotskystas apoiavam o trabalho de massas também em contraposição à luta armada. A resposta da repressão contra aqueles que enfrentavam a ditadura com armas em punho foi duríssima. Até 1972, os grupos foram dizimados. O cerco foi rápido. As ações dos $\mathrm{DOI}-\mathrm{CODIs}^{46} \mathrm{com}$ suas técnicas de tortura e terror psicológico se mostraram bem-sucedidas. $O$ isolamento político das organizações, suas crises

43 Magalhães, Mário. Marighella, o guerrilheiro que incendiou o mundo. São Paulo. Companhia das Letras, 2012.

44 Gorender, Jacob. Combate nas trevas. São Paulo. Expressão Popular e Fundação Perseu Abramo, 2013. Pg. 183.

45 Frank, André Gunder. El desarrollo del subdesarrollo. Pensamiento Crítico, Habana, № 7, agosto de 1967.

46 Sobre a repressão, o assunto será aprofundado no capítulo 4. 
internas e o próprio esgotamento da militância somaram para a derrota.

Das diferenças que existiam entre as organizações, a que mais nos interessa aqui é a análise do caráter da revolução. Justamente nesse aspecto é que se molda o cerne da identidade do tronco construído pela POLOP.

O VI Congresso da Internacional Comunista ${ }^{47}$, ocorrido em 1928, sistematizou a visão etapista, carregada pelo PCB e por suas dissidências. A primeira fase da revolução, tal como foi abordado acima, deveria se pautar pelo desenvolvimento das forças produtivas e pela independência nacional. Dessa forma, garantidas as condições objetivas e materiais, o caminho para o socialismo estaria aberto. Essa teoria cabia muito bem aos países do chamado terceiro mundo. O PCB enraizou tal tese no contexto da formação histórica do Brasil. O latifúndio e o imperialismo, segundo a tese, constituíam os principais entraves para o desenvolvimento da economia, sendo os motivos de sua estagnação. Portanto, a revolução nacional e democrática deveria quebrar essas barreiras históricas, abrindo caminho ao socialismo ${ }^{48}$.

O PCdoB compartilhava desse modelo esquemático, assim como a Ala Vermelha. Mesmo organizações que optaram pela luta armada o mantiveram. A Aliança Libertadora Nacional, de Carlos Marighella, como o próprio nome indica, defendia a premência da emancipação do país. O Partido Comunista Brasileiro Revolucionário partilhava também dessa tese, ainda que associasse a etapa nacional e democrática da revolução de forma menos mecânica à etapa socialista, de modo que ambas se confundiam, fazendo parte do mesmo processo. Para essas quatro organizações estava posta a tarefa de construir um governo popular e revolucionário. Fato é que o PCdoB e a ALA aceitavam a participação de setores da burguesia nacional, que supostamente viam no imperialismo um limite para os seus próprios

47 Antunes, Ricardo. Os comunistas no Brasil: as repercussões do VI Congresso da Internacional Comunista e a primeira inversão stalinista no Partido Comunista do Brasil (PCB). Pg. 16. O texto se encontra no portal do IFCH: https://www.ifch.unicamp.br/ojs/index.php/ael/article/view/2427/1839.

48 Bielschowsky, Ricardo. Pensamento Econômico Brasileiro - ciclo ideológico do desenvolvimento. Rio de Janeiro. Editora Contraponto. Pg. 181. 
interesses. Já a ALN e o PCBR eram céticos quanto a isso, o que se confirmou com a vitória e o agravamento da ditadura militar ${ }^{49}$.

Os defensores do caráter socialista da revolução questionavam a ideia de que no Brasil havia resquícios feudais. Ao contrário, compreendiam que o país era plenamente capitalista, integrado à economia mundial. Moniz Bandeira, um dos fundadores da POLOP - organização primeira que sistematizou a crítica ao etapismo assim explica sua interpretação:

"ao escrever O caminho da revolução brasileira, lançado em 1963, tratei de demonstrar, com dados econômicos e estatísticos do início de anos 1960, que o Brasil deixara de ser um país semicolonial e agrário, conforme a teoria do PCB, e já apresentava o perfil de uma economia capitalista madura. O valor da produção industrial, inclusive com um setor bastante adiantado de máquinas e equipamentos, superava o valor da produção agrícola, acelerando a concentração tanto de capital quanto da força de trabalho (cerca de quatro milhões de operários). Ao mesmo tempo, o rápido processo de urbanização, intensificado por inaudito êxodo rural, acentuava o predomínio da cidade sobre o campo. Daí o caráter socialista que adquirira a revolução ${ }^{50 " .}$

\subsection{A POLOP interpreta o Brasil}

Desenhado esse quadro mais amplo das diferenças, vale o olhar um tanto mais atento acerca da interpretação da formação social do país e do programa para revolução defendidos pela POLOP, pois o MEP usará da fonte dessa elaboração.

O IV Congresso da POLOP, realizado em 1967, elaborou o documento qu serviu de tese-guia para boa parte das forças políticas que defendiam o caráter socialista da revolução brasileira: trata-se do Programa Socialista para o Brasil $(\mathrm{PSPB})^{51}$.

O documento faz parte de um conjunto de reflexões, que começou com a série

49 Reis Filho e Ferreira de Sá. Imagens da Revolução. Documentos Políticos das organizações Clandestinas de esquerda dos anos 1961-1971. São Paulo. Expressão Popular, 2006. Observar as respectivas fichas de cada organização. Pg. 266; Pg. 205.

50 Revista Margem à Esquerda, №22. Entrevista com Moniz Bandeira. São Paulo. Boitempo, 2014. Pgs. 13-14.

51 A íntegra do documento encontra-se em Reis Filho e Ferreira de Sá. Imagens da Revolução. Documentos Políticos das organizações Clandestinas de esquerda dos anos 1961-1971. São Paulo. Expressão Popular, 2006. Pg 116. 
Aonde Vamos?, publicada no periódico Política Operária, entre 1966 e $1967^{52}$. O Programa Socialista para o Brasil, dessa forma, aparece como uma síntese elaborada após alguns anos de reflexão.

Dada a importância histórica das reflexões contidas no texto, faz-se imprescindível aqui exprimir as principais ideias. Vale dizer, pois, que o PSPB foi o marco da síntese no sentido da superação do que se convencionou chamar de teses reformistas. O programa busca localizar o momento internacional, desenha o quadro da formação do capitalismo no Brasil, analisa o caráter da revolução necessária e os grupos sociais nela envolvidos. Em síntese, encontramos a elaboração de uma perspectiva estratégica, seguida por uma tática a ser posta em ação.

De acordo com o texto, o atual momento da história é o do confronto final. O capitalismo se encontra em uma espécie de agonia profunda, construída por sua natural expansão, dada a força do capital, com a necessidade premente de sobrevivência. Sua ameaça maior passava a ser o avanço do socialismo, o qual abrangia dois terços da humanidade. A Revolução Russa- e seu bloco soviético, a Revolução Chinesa, os países africanos que, logo ao se tornarem independentes tendiam à aproximação do bloco aposto ao comandado pelos EUA, davam a dimensão da força do socialismo. A América Latina, embalada pela Revolução Cubana, entrava no radar dos povos insubmissos. Ferviam as ideias socialistas no mundo, enquanto o capitalismo não era capaz de liquidar as suas próprias contradições.

O imperialismo, portanto, se apresentava como maior adversário dos povos. Nesse quesito, a formulação da POLOP encontrava eco na leitura comunista tradicional, ainda que os desdobramentos políticos fossem diferentes. Para os polopistas, as duas guerras mundiais mudaram as bases do imperialismo. $O$ capitalismo central sofisticou sua forma de dominação. O processo de compra de matérias-primas seguida da venda de produtos manufaturados deixou de ser o centro para que em seu lugar chegasse o próprio capital, seja através da exploração de

52 Idem. Pg. 115. 
multinacionais ou pela entrada do capital financeiro. Dessa forma, os capitalistas centrais ganhavam com a exploração da mais-valia de dentro e de fora de suas fronteiras. Não havia mais a necessidade da ocupação física dos territórios, ao menos não da maneira como se deu até meados do século XX. Ao mesmo tempo, o conflito interimperialista era posto de lado frente à necessidade de combater a revolução mundial. Isso não significa que os conflitos deixaram de existir, mas que passou a prevalecer uma cooperação antagônica.

Interessante notar o lugar reservado à União Soviética. Sua postura no mundo não era caracterizada como imperialista. Ao contrário, havia uma clara posição de defesa de seu sucesso enquanto potência. Isso fica explícito quando o documento discute o mundo socialista. Começa, vale dizer, com um anátema teleológico: "o socialismo só pode vencer.".

Havia, sem embargo, os riscos. O embate com a economia capitalista oferecia uma ameaça à planificação econômica, sobretudo pelos gastos militares os quais os países socialistas eram obrigados a despender para garantir sua sobrevivência no conflito geopolítico. Por outro lado, as burocracias internas, construídas historicamente, ao mesmo tempo como contingência diante do contexto de guerra e como ferramenta indispensável para a sustentação interna do Estado, apresentavam limites objetivos. Precisavam, dito isso, de reformas na sua condição sócio-histórica. Além disso, afirmava o texto, a burocracia carrega consigo o peso nacional, fator limitador do internacionalismo.

Embora tais críticas tenham carga, o sucesso da luta socialista está condicionado menos às direções reformistas e mais à vitória de todo o campo comunista. Assim afirma o documento

\footnotetext{
"muito mais que as divergências e, mesmo, que as conciliações das direções reformistas, pesará em longo prazo o denominador comum do socialismo e da luta contra um mundo imperialista hostil e inconciliável. O papel hoje dos marxistas-leninistas nos debates internos é o de travá-lo na perspectiva da unificação do campo socialista em termos dos princípios revolucionários ${ }^{53}$ ".
}

53 Reis Filho e Ferreira de Sá. Imagens da Revolução. Documentos Políticos das organizações Clandestinas de esquerda dos anos 1961-1971. São Paulo. Expressão Popular, 2006. Pgs. 119-120. 
Dado o grau de sectarismo presente na esquerda dos anos 1960, essa formulação salta à vista pela proposta de unidade para combater um inimigo em comum. Inimigo este que subjuga, prioritariamente, os países do mundo subdesenvolvido.

Diferentemente da compreensão dos países do terceiro mundo somente como economicamente atrasados, ainda que nos marcos do capital, a leitura é que esse conjunto de países se caracteriza, antes de tudo, como objeto de exploração do imperialismo. Isto os define. A noção de cooperação antagônica entre os países centrais e os países periféricos é explicativa ${ }^{54}$. $\mathrm{O}$ imperialismo sobrevive às custas do sufoco econômico da colônia moderna, sendo que o país explorado vê, dessa forma, as chances de seu desenvolvimento praticamente minguarem. Todavia, existe uma elite nacional colonizada que ganha através do contato com as economias centrais. Justamente essas elites configuram o polo positivo da cooperação antagônica, enquanto a imensa maioria do povo constitui o polo negativo.

Isso posto, depreende-se que a luta nacional tem um papel fundamental na transformação socialista. As revoluções antiimperialistas converteram-se numa luta entre os dois blocos da geopolítica. O documento afirma:

as revoluções antiimperialistas transformaram-se rapidamente - graças à própria situação internacional - numa luta entre os dois sistemas antagônicos. O que vemos é que, mesmo nos países onde não está suficientemente amadurecida a contradição entre o capital e o trabalho, a internacionalização da luta se converte num choque entre os dois sistemas mundiais ${ }^{55}$.

Imprescindível registrar, aqui, a influência direta da Teoria da Dependência na visão da POLOP. Para além de seus autores - como Ruy Mauro Marini, Theotônio dos Santos e Vânia Bambirra, que foram militantes da POLOP - esta teoria aparece como uma inovação na leitura do capitalismo, sobretudo em relação à perspectiva dos povos subordinados ao imperialismo. Mais ainda, a noção de dependência foi fundamental para fortalecer a compreensão do caráter socialista da revolução. No momento em que o PSPB foi formulado, discutia-se o teor da dependência. Esta

54 Vale destacar que a noção de cooperação antagônica aparece tanto para falar da relação entre países imperialistas quanto para descrever a relação entre um país central e um periférico.

55 Idem. Pg. 120. 
teoria aparece de maneira mais elaborada no texto de Andre Gunder Frank, em 1967, chamado El desarrollo del subdesarrollo ${ }^{56}$. Uma vez que a dependência tenha se tornado pedra angular nas leituras da POLOP e posteriormente do MEP, vale apresentá-la.

O título carrega em si dois aspectos fundamentais da crítica de Frank: primeiro, a ideia de que o subdesenvolvimento dos países periféricos é uma consequência do desenvolvimento do sistema capitalista e, segundo, nos marcos econômicos atuais, a evolução possível desses mesmos países é o desenvolvimento do subdesenvolvimento, em outras palavras, os países pobres não podem se desenvolver mantendo a sua situação de dependência.

Como uma ressalva metodológica, Frank aponta a importância de não usar categorias de análise construídas através do estudo das sociedades metropolitanas para pensar as sociedades dependentes. Isso porque a "etapa" histórica ou mesmo a evolução das sociedades periféricas não encontram precedentes. Ele critica estudos sobre o desenvolvimento que consideram a relação econômica entre metrópole e colônia ao longo da história. O esquematismo que pressupõe etapas pelas quais toda sociedade passa, de acordo com a crítica, deve ser superado, enquanto a análise concreta de cada sociedade é o caminho que permite um olhar mais acurado.

As profundas desigualdades no interior das sociedades subdesenvolvidas gerou a falsa impressão de dualidade de sistemas econômicos. Havia uma parte mais sofisticada em termos materiais e outra, fragilizada. Ambas as partes, sem embargo, compunham um sistema uno. Frank aponta que as consequências políticas da aceitação da dualidade de sistemas reafirmam mecanismos que perpetuam o subdesenvolvimento ${ }^{57}$.

Isso se dá em razão do seguinte raciocínio. Um dos aspectos centrais da teoria de Gunder Frank, que de algum modo busca responder à questão da dualidade, é a 56 Frank, André Gunder. El desarrollo Del subdesarrollo. Pensamiento Crítico, Habana, № 7, agosto de 1967. Texto localizado em: http://www.filosofia.org/rev/pch/1967/n07p159.htm.

57 Idem. Pg. 159. 
existência da relação colônia/metrópole no interior dos países colonizados. A região "metropolitana" da colônia serve como um braço da metrópole capitalista avançada. Pensando no interior de um país pobre, há uma interdependência econômica e social entre a cidade e o campo, muito embora nessa relação desigual um lado acabe sendo mais privilegiado que outro. Este raciocínio não permite falar em duas unidades independentes, em dualidade. Dessa feita, apostar em um arranjo político para livrar o elo frágil implica em fortalecer o elo forte, de modo a fazer girar a roda da dependência.

O subdesenvolvimento latino-americano é resultado da participação secular do continente na economia mundial. Mesmo o fato de existir regiões ricas e com indústria no interior de países subdesenvolvidos, como São Paulo e Buenos Aires, não muda o caráter da dependência, nem dá margem para supor a viabilidade do desenvolvimento geral. A riqueza de uma região se faz pela pobreza de outra. Vale aqui uma citação direta do texto

El subdesarrollo no es debido a la supervivencia de instituiciones arcaicas o la existencia de falta de capital en las regiones que se han mantenido aisladas del torrente de la historia del mundo. Por el contrario, el subdesarrollo ha sido y es aún generado por el mismo processo histórico que genera tambíen el desrrollo econômico: el desarrollo del proprio capitalismo ${ }^{58}$.

A partir das observações acima, Frank levanta uma série de hipóteses. A primeira, o desenvolvimento das metrópoles subordinadas ou nacionais está limitado pelo seu estatuto de satélite. A segunda hipótese diz que o desenvolvimento industrial capitalista clássico é maior nos satélites quando seus laços com a metrópole são mais frágeis. Outra explicação que soma com esta hipótese é o distanciamento geográfico. O Japão, por exemplo, industrializou-se após a restauração Meiji por não ser satelizado. Quando a economia dos países centrais está em alta é o pior cenário para o desenvolvimento dos países dependentes. A terceira hipótese aponta que as regiões mais subdesenvolvidas e que aparentemente apresentam traços feudais são justamente aquelas que tinham no passado laços mais estreitos com a metrópole, como o nordeste brasileiro. Outras duas conclusões aparecem como complementares 
à anterior. O latifúndio nasceu como empresa capitalista e as instituições criadas tinham o papel de facilitar as transações comerciais.

Para sintetizar, vale a pena terminar com outra citação do autor:

El crescimiento del latifundio y sus condiciones de servidumbre, al parecer feudales, en América Latina ha sido siempre e es aún respuesta comercial a la creciente demanda y que no representa la transferencia o supervivencia de instituiciones ajenas que se han mantenido más allá del alcance del desarrollo capitalista ${ }^{59}$.

Ruy Mauro Marini, militante da POLOP, em seu texto clássico Dialética de la Dependencia $^{60}$ apresenta a maneira que se procedeu na história a construção do subdesenvolvimento como consequência da dependência que os países coloniais ou de passado colonial possuíam frente às metrópoles.

Para Marini, o capitalismo na América Latina é sui generis, ou seja, sua evolução não procedeu nos mesmos parâmetros das economias capitalistas clássicas, posto que desde o início da colonização sua função na economia mundial era servir ao centro. Após a revolução industrial nos países europeus, uma das consequências políticas foi a independência dos países latino-americanos, os quais trocaram o jugo das antigas metrópoles por outras mais modernas.

A dependência é compreendida como relação de subordinação entre nações independentes. Tendo em vista a subordinação, as relações de produção nos países dependentes funcionam como mecanismos de propagação da dependência.

Por inserir-se no mundo através da venda de alimentos e matérias primas, a América Latina permitia (e ainda permite) que a acumulação passe da mais-valia absoluta à mais-valia relativa nos países centrais, na medida em que lhes oferece insumos para a produção industrial e alimentos baratos, ajudando a manter altos os salários no centro. Isso se dá em razão da maior exploração do trabalhador latino-

59 Ibidem. Pg. 171.

60 Marini, Ruy Mauro. Dialética de La dependencia. Ver em: https://amauta.lahaine.org/dialectica-de-ladependencia/ 
americano. A América Latina, ao exportar bens primários e importar produtos manufaturados, importa também a mais-valia absoluta, resultando em taxas altíssimas de exploração. Eis a grande contradição da dialética da dependência. Para manter essa relação, é necessário um segredo nas relações de intercâmbio, e esse segredo é a tendência à deterioração nos termos de troca ${ }^{61}$.

A inserção latino-americana é contraditória em outro aspecto: a oferta de produtos baratos atenua de algum modo a composição elevada do capital constante no centro. Este capital é o que gera a tendência de diminuição da taxa de lucro. $O$ continente latino-americano importa essa tendência quando explora seus trabalhadores. Seja pela produção barata de mercadorias com baixo valor agregado, seja por ajudar a limitar o acúmulo de capital constante no centro, a consequência é a superexploração, garantida por uma vasta reserva de mercado de trabalho.

Observando essa relação de outro ponto de vista, o preço de mercadorias com maior valor agregado é mais estável do que mercadorias primárias. Disso resulta a deterioração nos termos de troca. Cabe pensar aqui que a força de trabalho também é uma mercadoria. Logo, a exploração dessa mercadoria não deixa de resultar da deterioração do intercâmbio.

Em sociedades atrasadas com baixa tecnologia, a exploração tende a ser maior. Essa situação faz a vida do trabalhador ser pautada exclusivamente para a sobrevivência. Como a reserva de mercado é alta, os trabalhadores têm que se submeter a regimes desumanos de trabalho. A superioridade perversa do capitalismo diante de outros modos de produção é a sua capacidade de aproveitar de boa parte do tempo de existência do trabalhador ${ }^{62}$.

Em linhas gerais, essas são as principais premissas da teoria da dependência de Gunder Frank e Marini. Cabe um último comentário a respeito da relação de exploração que a dependência proporciona, de modo a estabelecer a ponte entre os teóricos da dependência e o PSPB. O centro capitalista se vale da permanência de

61 Idem. Pgs. 07-08.

62 Ibidem. Pgs. 12-13. 
traços coloniais da relação econômica entre metrópole e colônia, ou seja, a venda de matérias-primas ou produtos de baixo valor agregado e a compra de produtos sofisticados. A novidade da relação de subordinação consiste na exploração através da presença do capital estrangeiro através das multinacionais e dos bancos. Esse todo conforma a posição subalterna do terceiro mundo na economia mundial.

Voltamos agora ao Programa Socialista para o Brasil ainda na esteira do debate sobre o centro e a metrópole, mas sob aspectos políticos. O documento busca exemplos que relacionam a questão nacional e o socialismo. As várias revoluções que combinaram esses dois aspectos influenciaram a perspectiva estratégica contida no documento. Mas uma dessas assumiu dimensão especial: a Revolução Cubana desenhou marco temporal e político, dividindo a história da América Latina. Foi a primeira vez que um país deste continente libertou-se de todo e qualquer imperialismo. A Revolução também se constituía como um exemplo. Os cubanos mostraram que o caminho do socialismo era possível.

Os países da América Latina comungam de um processo histórico semelhante. Diz o texto que:

o que os países latino-americanos têm em comum é um passado similar criado pelo domínio colonial ibérico, que deixou uma herança de problemas sociais parecidos, principalmente no campo ${ }^{63}$.

Os elementos de unidade histórica indicavam que os movimentos sociais de superação do capitalismo possuíam balizas comuns. A boa nova era que a Revolução Cubana "naturalizou o marxismo-leninismo no continente" 64.

Outro tópico de discussão do PSPB é sobre as lutas de classes no território. O documento dá ênfase à organização do capitalismo no Brasil, que seria de tipo industrial bloqueado. A herança colonial e o imperialismo são as razões do bloqueio. A

63 Reis Filho e Ferreira de Sá. Imagens da Revolução. Documentos Políticos das organizações

Clandestinas de esquerda dos anos 1961-1971. São Paulo. Expressão Popular, 2006. Pg. 124. 64 Idem. Pg. 124. 
questão da estrutura agrária assume dimensão central, uma vez que a concentração de terra surge como elemento do retardo econômico, pois sua produção é baixa e pouco diversificada. Como os resultados da produção são apropriados por poucos, mingua, por conseguinte, o mercado interno. O valor baixo da mão de obra, por sua vez, também é elemento que constitui tanto o mercado reduzido, quanto fator do atraso tecnológico, posto que o avanço técnico da produção é compensado pela exploração da mão de obra.

A burguesia industrial e a burguesia rural não são vistas como antagônicas. Ao contrário, aparecem como integradas historicamente. Prova disso se revela no fato de que o boom da economia cafeeira é que gerou capital para ser revertido nos primeiros esforços mais profundos de industrialização.

O campo aparece como plenamente integrado à economia capitalista, apesar de seus sinais de atraso. Como sugestão para resolver os imbróglios nos rincões do país, propunha-se que nos lugares em que a organização rural aparecesse mais avançada, caberia a coletivização da terra. Onde se encontrassem formas mais rudimentares, a reforma agrária seria um jeito de estimular o avanço produtivo. Como forma de preservação do campo, a nacionalização da terra vinha para frear a especulação.

A questão rural é estruturante exatamente porque através dela se deu a integração da colônia ao imperialismo. É fato também que a presença imperialista não é somente uma herança colonial. O imperialismo passou por transformações, especialmente da passagem do século XIX para o século $X X$.

Reproduzindo uma visão clássica do leninismo, o imperialismo é tido como a fase/estágio superior do capitalismo, quando a concentração de capitais ultrapassa fronteiras. Logo, a integração do Brasil ao imperialismo se deu na condição periférica. Mais uma vez, aqui, aprece a teoria da dependência. O imperialismo mantém o controle externo pela presença da indústria multinacional, exporta mais-valia absoluta, condicionando a super-exploração na colônia, e ainda exerce influência sobre os governos através de empréstimos bancários. A monopolização das 
indústrias impede o desenvolvimento pleno da economia local. O conjunto dessas condicionantes acentua as contradições capitalistas, fazendo com que o imperialismo seja a "antessala da revolução".

O socialismo, entendido como a sociedade em que os meios de produção são tornados comuns, é apresentado, no PSPB, como um desdobramento teleológico, resultado das transformações tecnológicas e das contradições capitalistas. Diz o documento:

o socialismo não é um mero desejo, nem tampouco uma elaboração artificial pela qual se pretende reformar o mundo. O socialismo é resultado da evolução histórica da humanidade, colocado na ordem do dia, quando a velha sociedade exploradora se torna um empecilho ao progresso geral - quando os homens tomam consciência desse fenômeno. Isso quer dizer que o socialismo é o resultado da luta de classes e de revoluções, que representam os momentos críticos dessas lutas. Esse fenômeno universal se dá também, evidentemente, no Brasill ${ }^{65}$.

Dado que a revolução ocorre em solo nacional, os polopistas se dedicam a entender a ditadura, para, ao enfrentá-la, construir as pontes para o socialismo. Caracterizam a ditadura militar como uma resposta à agudização do conflito de classe. A burguesia ancorou-se nos militares para manter seu controle sobre a contradição central entre burguesia e proletariado. A ditadura era burguesa e militar ao mesmo tempo. Essa caracterização apresenta várias conclusões políticas, as quais serão vistas mais à frente.

Criada a taxologia que envolve o imperialismo, o capitalismo no Brasil e o caráter da revolução, abre-se o caminho para as propostas que estão no âmbito da tática.

Por um governo revolucionário dos trabalhadores é a palavra de ordem que durará por quase duas décadas. Esse conceito é uma espécie de elo de transição entre as lutas do cotidiano e a instauração do socialismo. Seria uma ponte para a criação de uma sociedade pós-capitalista. Para construí-lo, o primeiro passo seria atacar as bases da ditadura militar, do ponto de vista de classe.

65 Ibidem. Pg. 134. 
No campo da tática, seria necessária a construção de uma frente dos trabalhadores da cidade e do campo - outra palavra de ordem cara à tradição polopista - organizada, sobretudo, por local de trabalho. Dados os limites dos sindicatos, isso em razão da intervenção ministerial ou pelas direções pelegas, a forma organizacional ideal era o comitê de empresa.

Em se tratando dos trabalhadores do campo, caberia organizá-los através de uma vanguarda armada. Segundo o documento:

radicalizados pela miséria extrema a que são levados no atual regime, mas impotentes ante o poder e as armas das classes possuidoras, essas massas rurais - assalariados puros, parceiros, meeiros, pequenos camponeses etc. - dependem de uma vanguarda armada que leve ao campo a perspectiva e a experiência de organização do proletariado armado urbano ${ }^{66}$.

Ecos da Revolução Cubana, mais uma vez, aparecem.

Ao movimento estudantil cabia a tarefa de denunciar o regime e, assim, contribuir para sua desestabilização. O potencial de trazer novos militantes dessa área era reivindicado. Os militares de baixa patente, guardado o seu turno, faziam lembrar os sovietes de operários e soldados. A eles, soldados, cabia somar forças para a revolução e desorganizar por dentro a estrutura da repressão.

Sobre o conceito de governo de transição, o próprio documento ressalta um elemento de indeterminação.

Embora as circunstâncias que temos em frente não permitam previsões de detalhes sobre a formação do governo de transição de caráter revolucionário que pode preceder e levar à ditadura do proletariado, o conteúdo de classe de tais governos provisórios deve ser definido desde já $a^{67}$.

Vê-se a preocupação em torno da raiz classista, como uma espécie de antídoto de possíveis desvios. O programa do governo revolucionário dos trabalhadores ${ }^{68}$ pode ser assim sintetizado:

- destruição das atuais forças armadas.

66 Ibidem. Pg. 140.

67 Ibidem. Pg. 141.

68 Ibidem. Pg. 143. 
- encampação dos monopólios imperialistas e nacionais.

- nacionalização da terra e eliminação do latifúndio. Organização de cooperativas, criação de fazendas coletivas e entrega de terras aos camponeses.

- liberdade de organização e manifestação.

- política externa antiimperialista e solidariedade às lutas revolucionárias, em especial na América Latina.

- retirada da grande imprensa do controle dos capitalistas

- convocação de um congresso dos trabalhadores da cidade e do campo, como base do novo regime.

- medidas drásticas de combate à carestia, confisco dos estoques de especuladores, controle dos preços e elevação geral dos salários.

Para dar conta desse programa, a vanguarda precisaria investir na formação do partido revolucionário, hegemonizado pelo proletariado.

A POLOP considera a importância de se criar um movimento, uma frente, na sociedade, ao lado de outras organizações marxistas e revolucionárias, em direção à criação do partido político. Para tanto, lutas em três frentes deveriam ser travadas: no plano econômico, através das reivindicações salariais e por melhores condições de trabalho; no campo da política, denunciando a ditadura a serviço da exploração de classe e, em terceiro lugar, no plano ideológico, algo que consiste na denúncia anticapitalista e na defesa do socialismo.

A construção do partido seria uma derivação da frente de esquerda revolucionária. O desenvolvimento da atividade política abriria espaço para a criação de um partido à base da teoria marxista-leninista, reconhecendo o caráter socialista da revolução, levada adiante por um movimento hegemonizado pelo proletariado. Ao lado da organização operária por lugar de trabalho, há também a defesa da luta de 
guerrilhas.

Por fim, o Programa Socialista para o Brasil termina conclamando a guerra revolucionária, último nível do conflito político. O sucesso da revolução depende da insurreição operária. A novidade, todavia, estava na guerrilha, modalidade de luta sofisticada na América Latina. Havia o reconhecimento de que o processo de transformação seria longo. Logo, a guerrilha, nesse quadro, cumpriria um papel no acúmulo de forças:

"Realizando, desde o início, em miniatura, a frente dos trabalhadores da cidade e do campo, a guerrilha potencializará a voz clandestina em todo o país, preparando o reagrupamento das forças das classes revolucionárias para a luta final ${ }^{69}$ ".

\subsection{A Polop desmembra-se}

O imperativo prático de sobrevivência política impunha suas regras e dificuldades. A POLOP, depois de surgir em 1961, realizou outros três congressos: em 1963, 1964 e, o último, em 1967, quando a organização rachou. O grupo de Minas Gerais e alguns membros da Guanabara criaram o que veio a ser os Comandos de Libertação Nacional (COLINA), ao lado de militantes de movimentos de militares. Nomes como Maria do Carmo Brito, Juarez Guimarães Brito e Carlos Alberto de Freitas estavam nesse processo. Dilma Vana Rousseff e Fernando Pimentel depois se somariam. Vinda de São Paulo, outra seção da POLOP aproximou-se de Onofre Pinto, ex-sargento, e formou a Vanguarda Popular Revolucionária (VPR). Os dois agrupamentos, atacados pela repressão, formaram - em 1969 - a Vanguarda Armada Revolucionária - Palmares (VAR-Palmares).

Aqueles que não foram para os COLINA nem para a VPR, uniram-se à Dissidência Leninista do Rio Grande do Sul, vinda do PCB, dando origem ao Partido Operário Comunista (POC). Marco Aurélio Garcia, Flávio Koutzi e Nilton Santos estavam lá ${ }^{70}$.

69 Ibidem. Pg. 148.

70 Mattos, Marcelo Badaró. "Em busca da revolução socialista. A trajetória da POLOP (1961-1967)". In: Ridenti, Marcelo; Reis Filho, Daniel Aarão (org.). História do Marxismo no Brasil - partidos e 
Com bases no Rio Grande do Sul, São Paulo, Minas, Rio de Janeiro, Paraná, Bahia e Pernambuco, o POC buscava fazer um trabalho de agitação entre operários e estudantes. Chegaram a editar dois periódicos, o União Operária e o Universidade Crítica. Seu primeiro congresso reivindicava o Programa Socialista para o Brasil $^{71}$.

Em junho de 1968, o Comitê Nacional do POC editou um documento chamado Por uma prática partidária. O objetivo era refletir sobre os limites da sua própria organização. Ao mesmo tempo em que o POC reconhece que seu traço distinto é a ênfase dada ao protagonismo da classe operária, percebe como sua maior debilidade a incapacidade de intervenção no interior da classe. Mais do que isso, anuncia as dificuldades de ganhar militantes oriundos da classe operária, formar ativistas para intervir em nome do partido e mesmo ganhar novos membros em geral. A grande questão no texto trata-se de como sobreviver. Esse dilema é existente em praticamente todas as organizações do período. Reflete, aliás, o clima de cerco da ditadura, com o qual as possibilidades de ação estavam cada vez mais esgarçadas. A postura autocentrada também fica muito nítida, quando se questiona a ação unitária entre organizações socialistas.

"A prática mostrou e continua mostrando que todas as alianças feitas com outras organizações tornaram-se precárias para nós quando estendidas à atividade prática no seio da classe operária. Isso ocorre pelo simples fato de que não pudemos, ainda, oferecer uma alternativa prática, clara e definida no nível da militância revolucionária no seio do proletariado ${ }^{72}$."

A citação acima demonstra uma dificuldade geral de ação. Quanto mais difícil se tornava agir publicamente, mais centradas em si mesmas as organizações ficavam. Curiosamente, a disposição de partir para a luta armada aumentava conforme se intensificavam os tormentos da ditadura. Isso levou o POC à divisão em março de 1970, após as resoluções da Conferência de São Paulo. As diferenças quanto à luta armada e questionamentos ao PSPB levaram à criação da Organização

organizações dos anos 1920 aos 1960, V 5. Campinas. Unicamp, 2002. Pgs. 198-199.

71 Silva, Antonio Ozai da. História das tendências no Brasil: origens, cisões e propostas. São Paulo. DAG, 1986. Pg. 124.

72 Reis Filho e Ferreira de Sá. Imagens da Revolução. Documentos Políticos das organizações Clandestinas de esquerda dos anos 1961-1971. São Paulo. Expressão Popular, 2006. Pgs. 236-237. 
Comunista Marxista Leninista - POLOP, a qual se manteve fiel ao documento. A OCML-POLOP era chamada de PO (Política Operária) $)^{73}$.

O novo grupo surgiu com contatos em São Paulo, Minas Gerais, Bahia, Paraná, Pernambuco e, principalmente, no Rio de Janeiro. Possuía entrada, sobretudo, no movimento estudantil e algum contato com círculos operários. Do ponto de vista programático, dava ênfase no trabalho operário. Seu documento fundador chama-se Declaração Política, datado em abril de $1970^{74}$.

Neste, destaca-se que o maior problema da esquerda se dava pela falta de inserção no seio do proletariado e pelo predomínio de ideias e métodos pequenoburgueses. A tarefa central da esquerda consistia em tornar-se proletária. Entendem que o fracasso das direções reformistas e o fim da ilusão quanto ao caminho pacífico abriram espaço para uma política revolucionária. A luta armada e seus feitos exemplares não poderiam, entretanto, substituir o trabalho no seio da classe, o qual deveria se dar através dos polos proletários. A PO criticava o desvio militarista, que afastou um conjunto de militantes da prioridade política, ou seja, atuar com os operários. Afirmavam que a ditadura militar, dado o estado de miséria e exploração do povo, mantinha uma estabilidade frágil, a qual, em algum momento, enfrentaria levantes de indignação. Para dar vazão ao sentimento de revolta, seria necessário organizar um partido político com organizações operárias dispersas e embrionárias, em uma direção anticapitalista ${ }^{75}$.

Mal surgida, a OCML-POLOP sofreu críticas no seu interior em relação ao dogmatismo de suas posições. As linhas gerais eram consideradas corretas, embora o exagero ideológico agisse no sentido de impedir o crescimento da influência da organização. Os responsáveis por essas críticas criaram a Fração Bolchevique.

73 Mattos, Marcelo Badaró. Em busca da revolução socialista. A trajetória da POLOP (1961-1967). In: Ridenti, Marcelo; Reis Filho, Daniel Aarão (org.). História do Marxismo no Brasil - partidos e organizações dos anos 1920 aos 1960, V 5. Campinas. Unicamp, 2002. Pg. 198.

74 Reis Filho e Ferreira de Sá. Imagens da Revolução. Documentos Políticos das organizações Reis Filho e Ferreira de Sá. Imagens da Revolução. Documentos Políticos das organizações Clandestinas de esquerda dos anos 1961-1971. São Paulo. Expressão Popular, 2006. Pg. 364.

75 Idem. Pg. 369. 


\section{FRAÇÃO BOLCHEVIQUE (1970-1976)}

O caldeirão de pólvora que constituía o início dos anos 1970 tornava muito difícil- e perigosa- a luta de resistência política. Essa dificuldade se expressava nas faculdades de agir e pensar. Disso resulta a multiplicação de siglas revolucionárias, formando ampla constelação de vontades e intenções. A Fração Bolchevique nasce nesse processo, no mês de novembro do ano que o Brasil levou o tricampeonato mundial de futebol. Um militante que acompanhou o itinerário vindo da Dissidência Comunista do Rio Grande Sul, seguindo com o POC, recompôs a OCML-PO e, por fim, formou a Fração Bolchevique, Nilton Santos afirma que o deslocamento da Fração se deu por volta de seis meses após a volta da $\mathrm{PO}^{76}$.

A Fração contava com poucos membros, concentrados, principalmente, no Rio de Janeiro e São Paulo. A atuação política rondava o movimento sindical e existia, de fato, no movimento estudantil. O motivo de surgimento da Fração Bolchevique se dava por conta do distanciamento político que havia em relação à $\mathrm{PO}$. A FB dizia que a POLOP, ainda que certa em relação aos pressupostos do Programa Socialista para o Brasil e também em relação à compreensão do marxismo, incorria em desvio doutrinarista. O grupo pensava de maneira correta, mas não conseguia encaixar o pensamento à prática; não aproximava a leitura à luta. Antonio Ozai da Silva assim comenta a crítica:

"Esta visão doutrinária estaria dificultando a avaliação objetiva da realidade; gerava divergências nas análises conjunturais e consequentemente nas propostas práticas e estaria transformando a POLOP num organismo autoritário, ultracentralizado e sectário ${ }^{77}$.

Mais um exemplo de política doutrinarista da POLOP se encontrava no movimento estudantil. Luiz Arnaldo ${ }^{78}$ comentava que os polopistas, no início dos anos 1970, assumiam uma postura que criticava exclusivamente a política educacional do

76 Entrevista concedida por Nilton Santos em 11/01/2019.

77 Silva, Antonio Ozai da. História das tendências no Brasil: origens, cisões e propostas. São Paulo. DAG, 1986. Pgs. 125-126.

78 Entrevista concedida por Luiz Arnaldo Campos em 11/01/2019. 
governo e fazia agitação pelo socialismo. Eles não discutiam bandeiras democráticas ou as eleições. Se pautavam somente pela crítica da política educacional. Por essa razão, diziam ironicamente à época que a POLOP nas universidades ia do bebedouro ao socialismo, uma vez que não havia mediação alguma.

De acordo com relatos de militantes da Fração que constam no Inquérito Policial Militar resultante da queda da organização, havia outro problema que levaria ao fracionamento ${ }^{79}$. Entendiam que não existiam canais internos de crítica, tampouco espaço para reavaliar na prática o jeito de se fazer política. Chegaram a reclamar o direito de ser uma fração da PO na Guanabara (e no Rio de Janeiro), possuindo certa autonomia. Além disso, exigiam representação na Direção Nacional da PO. O direito de ser fração na OCML-POLOP era concedido somente em período congressual.

Dessa forma, os pleitos da Fração Bolchevique não foram aceitos.

A FB considerava as divergências com a $\mathrm{PO}$, em um primeiro momento, secundárias. A lembrar, criticavam o excesso de ideologia em contrapartida da atuação prática. O central era manter o acordo estratégico, ou seja, a partir das formulações contidas no Programa Socialista Para o Brasil, unificar as vanguardas no sentido da criação do partido revolucionário da classe operária. A Fração compreendia que tanto a POLOP quanto o POC cabiam nessa caracterização. Embora a intenção fosse a da unificação, o que se verificou foi o contrário. Cada um desses grupos acabou seguindo em raia própria, o que revela as imensas dificuldades do momento.

\subsection{Do crescimento à queda}

A Fração Bolchevique experimentou crescimento rápido, com ênfase no movimento estudantil, no então estado da Guanabara, hoje cidade do Rio de Janeiro. Esse crescimento pode ter sido resultado do ânimo que existe quando surge um grupo político. Logo, os radares da repressão o localizaram. Como de praxe, 
montaram uma grande operação, levando quase ao desbaratamento total da Fração em meados de 1971 e início de $1972^{80}$.

A queda teve um impacto importante na esquerda carioca. Em um primeiro momento, dezesseis foi o número de indiciados no âmbito da $1^{a}$ Auditoria da Marinha. A acusação era de ação subversiva segundo a Lei de Segurança Nacional. Importante registrar que o período que envolve o início dos anos 1970 foi o auge do terror de Estado. O Ato Institucional $N^{0} 5$ estava em pleno vigor ${ }^{81}$, assim como as engrenagens da repressão. Praticamente todas as organizações que atuavam na clandestinidade foram atingidas.

Os ativistas ligados à Fração indiciados foram André Luiz Pappi, Angelina Teixeira Peralva, Estrela Dalva Bohadana, Burztyn, Fabio de Silos Sa Earp, Jorge Eduardo de Sousa Hue, Luiz Felipe Falcão, Manuel Maurício de Albuquerque, Maria do Carmo Navarro da Silva, Marlene Seica Shiroma, Nilton Bahlis dos Santos, Regina Maria Alves de Carvalho, Ricardo Henrique Salles, Roberto dos Santos Bathol, Sergio de Castro Lopes, Valeska Peres Pinto e Vera Maria Joppert Carneiro de Mendonça.

Através dos autos de investigação, evidencia-se o perfil do grupo. Dos dezesseis indiciados, doze eram estudantes, um professor e outros três militantes não tiveram reveladas as suas atribuições profissionais. O mais velho da lista possuía 27 anos, enquanto o mais novo, 20. A maioria concentra-se entre 20 e 22 anos de idade. Nem todos acima indiciados foram presos. Alguns conseguiram se manter foragidos. Dos foragidos, um menor número seguiu para o exílio.

A Fração possuía a seguinte estrutura organizativa: havia uma Direção, responsável pelas formulações teóricas e práticas. O Setor Interno cuidava da logística do grupo. Nas chamadas frentes de massa, estavam o Setor Estudantil e o Setor Operário. O trabalho político em São Paulo, organizado por egressos de POC, era chamado de Setor Três. Existiam também os Organismos de Prática Orientada

80 Reis Filho e Ferreira de Sá. Imagens da Revolução. Documentos Políticos das organizações Clandestinas de esquerda dos anos 1961-1971. São Paulo. Expressão Popular, 2006. Pg. 453.

81 Napolitano, Marcos. 1964 - História do Regime Militar Brasileiro. São Paulo. Editora Contexto, 2014. Pg. 119. 
(OPO) e os Organismos de Prática Partidária (OPP). As reuniões dos militantes ou contatos se davam na praia, em carros, nas residências e universidades.

A principal publicação trabalhada pela organização, nesse início, era o jornal Pavio, publicado entre 1970 e $1971^{82}$. Como ferramenta do trabalho de massas, havia também o Pavio Operário. Para um círculo mais próximo de militantes, alguns textos eram Formação de Núcleos Operários, História do Movimento Operário - convocação aos companheiros combatentes e Luta Política ${ }^{83}$.

Quanto ao trabalho estudantil, a Fração designava as universidades por grupos. Por exemplo, a UFRJ era o Grupo 1, com seu devido responsável pelo acompanhamento político. A PUC era o Grupo 2. A Universidade do Estado da Guanabara, a UFF e cursinhos pré-vestibulares eram, respectivamente, os Grupos 3, 4 e 5. Na UFRJ, atuavam nos cursos de Engenharia e Arquitetura, na Ilha do Fundão, no Instituto de Filosofia, na Economia, acompanhavam a Medicina, a Escola Superior de Desenho Industrial, Comunicação e Psicologia. Na PUC, tinham contatos, embora não codificassem os cursos. Na UFF e na Estadual da Guanabara não possuíam trabalho. Ao lado de estudantes secundaristas pré-vestibulandos, algo incipiente. Quanto ao trabalho sindical, constam iniciativas de panfletagens em locais de concentração operária, tal qual Volta Redonda.

Com base em meses de investigação, a qual revelou as informações acima citadas, no dia 31 de janeiro de 1972, o coronel Pedro Luis de Araújo Braga ${ }^{84}$,

82 Reis Filho e Ferreira de Sá. Imagens da Revolução. Documentos Políticos das organizações Clandestinas de esquerda dos anos 1961-1971. São Paulo. Expressão Popular, 2006. Pg. 453.

83 BNM_669 (3).

84 Interessante notar que o coronel Pedro Luís de Araújo Braga, responsável pela violência contra os militantes da Fração Bolchevique, tornou-se general. Continuou sempre um anti-comunista ardente. No dia 26/09/2014, Araújo Braga, ao lado de outros 26 generais, assinou uma carta recusando-se a pedir desculpas em nome do Exército pelos crimes cometidos contra a Humanidade. A solicitação foi feita pela Comissão Nacional da Verdade. Afirmam, os militares, terem salvado o país de grupos que queriam impor "terrível regime". Estudando os grupos revolucionários, formados principalmente por jovens, afirmações como essa soam criminosas. Atacaram um mosquito com uma bazuca, como se dizia na época. Sites de extrema-direita chegaram a publicar também em 2014 textos de propaganda anti-comunista de autoria do oficial citado. A não punição dos responsáveis pelos crimes de Estado cobrou altíssimo preço a longo prazo. O general Araújo Braga morreu em 15 de junho de 2018, recebendo honrarias do Clube Militar. Ver: http://g1.globo.com/politica/noticia/2014/09/cnv-critica- 
responsável pelo Inquérito Policial Militar, determina as prisões de Angelina Teixeira Peralva, Vera Maria Joppert Carneiro de Mendonça, Sérgio de Castro Lopes, Valeska Perez Pinto, Marlene Seiko Shiroma, Fabio de Silos Sa Earp, Roberto dos Santos Bartholo Júnior, Aloísio da Silva Lima, José Arrabal Fernandes Filho, Ethel Leon Arrabal Fernandes, Silvia Reisb Bregman, Maria do Carmo Freitas Ribeiro, Ricardo Henrique Salles, Pedro Luiz Carvalho da Motta Veiga, Humberto Derci Capai, Virgínia Murad, Lourdes Zmetek, Márcio Serôa de Arújo Coriolano e Lauro Escorel de Moraes Filho. Todos eles foram condenados a 30 dias de prisão, durante as investigações, de acordo com o Decreto-Lei N898, de 29 de setembro de 1969. Foram mandados para o Primeiro Batalhão de Polícia do Exército para depois arcarem com as possíveis consequências da Lei de Segurança Nacional. Nos fundos deste Batalhão, localizado na temerosa rua Barão de Mesquita, estava o DOI-CODI do Rio de Janeiro. O cerco de horror da ditadura militar se abatia sobre a Fração Bolchevique.

Até o momento correspondente à queda, pouco material com mais substância, densidade, foi encontrado. Possivelmente, a Fração Bolchevique dedicava-se mais ao esforço prático de angariar novos membros que de se dedicar ao trabalho reflexivo. Afinal, a crítica que faziam à $P O$ era justamente pelas dificuldades operacionais do grupo. Por outro lado, o golpe da repressão certamente fez sumir muito documento. Os militantes que não caíram, por óbvio, não estavam interessados em produzir novas provas.

\subsection{Primeiras formulações}

As prisões mudaram radicalmente o comportamento da Fração Bolchevique. Uma certa euforia vista com o crescimento dos primeiros meses foi substituída pelo amargor da derrota vinda à base de violência estatal. A queda foi um elemento marcante nas primeiras reflexões. Impedidos temporariamente de agir de maneira

manifesto-em-que-generais-se-negam-pedir-desculpas.html; http://www.folhapolitica.org/2014/03/general-diz-que-militares-estao.html 
pública, concentraram-se nos erros do passado que levaram ao brutal enfraquecimento. Olhando adiante, passaram a buscar um caminho composto pela estratégia socialista construída a partir de esforços no presente.

No documento Tribuna de Debate ${ }^{85}$, dois textos são apresentados. O primeiro As tarefas políticas da organização e o segundo Que caminho seguir?. Seguindo a velha chave balanço e perspectiva, esses textos buscam reorientar o grupo.

No primeiro texto, iniciam um esforço para entender por quais motivos a organização se deixou golpear ${ }^{86}$. Algumas ideias foram evocadas para tanto. $O$ imediatismo aparece como um erro de ansiedade política. A vontade de crescer rapidamente desdobra em outros problemas, que serão abordados mais adiante. $O$ abandono da consolidação da vanguarda é um erro que envolve má formação da coluna de quadros e dificuldade de criar relacionamento entre as vanguardas. Por último, identificaram o problema do paternalismo. A aproximação militante se dava mais pelo acolhimento do que por uma sólida formação política.

A concatenação desses elementos criou um seríssimo problema de segurança. Ao lado desses mesmos elementos, houve outro de confusão política. O crescimento rápido no movimento estudantil levou à falsa impressão de que o momento era positivo, afirmativo. Quando, na verdade, se vivia o oposto, de modo que as organizações da resistência corriam riscos reais de deixar de existir.

A percepção desse quadro se deu exatamente pelos ataques da repressão. Logo, o elemento sobrevivência passou a ser chave do exercício da política. Assim sendo, passaram a entender que uma organização forte não é aquela que possuí grande número de militantes, mas é aquela que agrega um verdadeiro núcleo de militantes revolucionários. Buscam, a partir disso, uma política de transição.

No documento Que caminhos seguir? buscam relacionar o passado a uma

85 DOC 857, DARF, FB 02-01. Agosto de 1972.

86 Além da Tribuna de Debate, existiam circulares internas. Segundo a Tribuna de Debate 1, houve uma circular 1 que tratava dos motivos da queda e também buscava um balanço crítico. No entanto, este documento não foi encontrado. 
política transitória. A questão da prática encontra aqui um lugar privilegiado. Resgatam a crítica ao PCB. Na verdade, apresentam uma crítica da crítica ao PCB. $O$ texto afirma que a crítica ao reformismo surgiu em um momento de repressão, fato que dificultava a criação de um polo revolucionário. A ORM-POLOP teve o mérito de reabilitar o marxismo no Brasil, muito embora sua crítica possuísse fragilidades.

O PCB, pontuava o documento da FB, era reformista - ainda que não doutrinarista - por interpretar de modo equivocado o desenvolvimento do capitalismo no Brasil. Dito isso, agia com base na conjuntura. Um exemplo dessa prática era a linha política pautada pela coexistência pacífica. Ou seja, uma leitura conjuntural desdobrava-se em linha política. O PCB conseguia fazer política justamente por focar numa dada contradição do momento, por mais que essa contradição estivesse mal alinhada à compreensão fiel do processo histórico brasileiro.

A ORM-POLOP conseguia apresentar a crítica teórica. No entanto, falhava quanto à crítica da prática política do reformismo. Sem conseguir precisar esta crítica, a prática da ORM absolutizou a contradição capital-trabalho, dela fazendo a determinante de toda a prática política. Afirma a Fração que, para a prática politica, não é a consciência o objeto básico, mas as relações sociais. Ao colocar o trabalho prático no campo da consciência, desdobra-se o proselitismo.

Caberia à esquerda revolucionária equacionar a prática ao programa. Aqui se apresenta uma mea-culpa do fracionamento. Achava-se que a multiplicação de grupos poderia acelerar a luta política. Não foi isso o que se passou. Como as diferenças com a OCML-POLOP eram secundárias, poderiam ter sido tratadas em outro campo. Caberia o esforço- para superar toda a sorte de barreiras, de buscar unir as vanguardas socialistas, evitando os desvios reformistas e militaristas.

Outro documento que possui imenso valor para a Fração Bolchevique, como aponta o pesquisador Carlos Henrique Menegozzo ${ }^{87}$, chama-se Os desvios da vanguarda operária na luta pela construção do partido. Datado em 01 de setembro de

87 Menegozzo, Carlos Henrique Metidieri. Fração Bolchevique (1970-1976). São Paulo, fevereiro de 2008 (mimeo). Pg. 02. 
1972, apresenta uma síntese da política da Fração naquele momento.

Em linhas gerais, diziam que as classes dominantes não permitiriam que a classe operária por si só construísse a sua libertação. Para isso, usariam os mecanismos de alienação: o próprio trabalho e meios difusores da ideologia dominante. Haveria a necessidade de uma vanguarda ilustrada, formada por pessoas com acesso à cultura, agir no sentido de criar uma teoria revolucionária. Do encontro entre a classe operária com essa vanguarda ilustrada surgiria o partido revolucionário.

Para tanto, dois desvios deveriam ser evitados. Primeiro, o sindicalismo, que significa condicionar a luta aos interesses econômicos ou imediatos da classe, desconsiderando as questões políticas. Segundo, o obreirismo, entendido como uma prática operária conduzida no âmbito da educação e da formação (círculos), deixando de lado o contexto global da sociedade.

Daniel Aarão Reis aponta o documento $\mathrm{Na}$ luta contra a ditadura, formar a vanguarda socialista, editado no Chile em $1972^{88}$, como sendo o responsável por tornar públicas as posições da Fração. Tendo em vista os tópicos abordados no documento, faz sentido que este tenha circulado. Isso não significa, evidentemente, que o conteúdo apresentado fosse imune a críticas. Significa, todavia, que as questões debatidas eram, de fato, pertinentes. Mais do que isso, tratavam-se de pontos fundamentais para o conjunto da esquerda.

O documento começa com uma homenagem ao Partido Comunista Brasileiro, em nome de seus fundadores José Elias, Cristiano Cordeiro, Hermógeno Silva e Astrojildo Pereira. 1972 marcou o aniversário de 50 anos do PCB. Reconhecem o esforço de unificação dos comunistas em torno da bandeira proletária, a disposição de enraizar no Brasil o socialismo científico, com base no marxismo-leninismo. Afirma o documento que por mais que o PC tenha mudado de rumo e aderido ao reformismo, o esforço originário do partido é o mesmo que deveria ser aplicado no

88 Reis Filho e Ferreira de Sá. Imagens da Revolução. Documentos Politicos das organizações Clandestinas de esquerda dos anos 1961-1971. São Paulo. Expressão Popular, 2006. Pg. 453. O documento encontra-se em DOC 857, DARF, FB 02-01. 
momento: unificar os comunistas em torno de um partido do proletariado e munido por um programa marxista. Essa é a grande orientação política.

Para tanto, reconhecendo o problema da prática reformista, e suas consequências para o golpe militar, seria necessário combater dois desvios. Quais sejam, o obreirista e o militarista. Explicam o sucesso da empreitada militar em cima das fragilidades da esquerda. Como não houve um trabalho de preparação ideológica sólido, o movimento operário se viu incapaz de fazer frente aos golpistas.

No que tange à caracterização da ditadura, vão adiante. Entendem que a burguesia descartou a opção democrática em razão da necessidade de encontrar um regime político capaz de sustentar um grau de exploração da mão-de-obra que desse conta de superar a crise econômica e aumentar a taxa de lucro. Desse modo, a polarização não estava mais entre ditadura versus democracia, mas entorno de qual é a ditadura adequada para este propósito. A possibilidade de sucesso econômico estava na capacidade de arrochar salários através da super-exploração ${ }^{89}$. A burguesia precisava do regime político da super-exploração. Este propiciaria elementos fundamentais para o acerto da economia do ponto de vista da burguesia. A exploração brutal da classe trabalhadora permitiria distribuir recursos para setores da classe média se tornarem consumidores de mercadorias com maior valor agregado. Essa mesma super-exploração ajudaria na acumulação interna de capital, assim como facilitaria a atração de capital internacional, além de reduzir o custo da mercadoria produzida no Brasil.

Desta caracterização desdobra-se outra de imensa importância política, que tem a ver com a pertinência das bandeiras democráticas. Diziam que, como a burguesia havia descartado a democracia por razões econômicas, levantar palavras de ordem democráticas seria o mesmo que pregar no deserto. Não teria eco. A cisão que poderia haver no interior da burguesia seria, no máximo, em torno de concessões para a classe operária se mover de modo a atenuar a radicalidade da política de arrocho.

89 Mais uma vez, fica explícita a presença da teoria da dependência nessas formulações. 
Outro elemento que se discute tem a ver com a seguinte pergunta: o que impede a classe trabalhadora de reagir? Diziam que, mais que a repressão policial, o que aprisionava a classe era a consciência. Outros contextos repressivos não impediam lutas de resistência. O que houve no Brasil foram anos de subversão da consciência. Nesse sentido, agiram para tal a burguesia, através de seus mecanismos de transmissão ideológica, e a própria experiência da esquerda, que flutuava entre o populismo e o reformismo. Logo, seria necessário criar condições para reposicionar a consciência da classe. Esse exercício se fazia mais importante que a luta pela destruição do aparato repressivo. Aqui entrava outra crítica à opção militarista. Não se tratava de ações de vanguarda deslocadas da massa, tampouco de achar que a população estava sedenta por armas. Criticava-se também aqueles que buscavam apoio em frações da burguesia para desmontar a arquitetura da repressão.

Dito isso, o desafio estava no campo da organização clandestina. Criar formas de agitação e propaganda. Fazer com que as direções políticas fossem conhecidas somente pelos interessados em superar a exploração. Criar formas indiretas de negociação. Estabelecer pontes entre diversas coordenações clandestinas de variadas fábricas. Agindo nessa direção, a vanguarda poderia resgatar a experiência e a tradição da classe; organizar pequenas lutas e, em síntese, colocar a consciência em novo patamar.

Está posto no texto que o enfraquecimento do partido reformista não desembocou no fortalecimento da esquerda revolucionária. Esta seguia ilhada, desarticulada e sem ação sistemática. Caberia a criação de uma Frente de Izquierda Proletaria ${ }^{90}$ para superar a fraqueza das frentes avançadas, buscar uma coordenação nacional da luta política e sistematizar experiências passadas. Assim se poderia criar uma vanguarda ampla, enraizada na classe. Essa frente não precisaria ter pleno acordo estratégico e programático, justamente para permitir uma amplitude maior de envolvidos na tarefa. O central era criar um movimento operário independente em luta

90 Essa consígna não era usual, mas assim ela se encontra no documento em questão. 
contra a ditadura. Esta articulação se daria na luta concreta, vinculada com as tarefas da conjuntura. Esses elementos foram sintetizados na consigna na luta contra a ditadura, formar em cada fábrica a vanguarda socialista.

\subsection{Fazer do exílio uma campanha}

O exílio foi uma experiência marcante na vida da Fração Bolchevique. Como visto anteriormente, as prisões realizadas no fim de 1971 alteram por completo a dinâmica de funcionamento da organização. Em um primeiro momento, o Chile foi a morada daqueles que escaparam da repressão. No auge do governo da Unidade Popular, liderada pelo presidente Salvador Allende, a realidade chilena se apresentava como uma espécie de polo oposto comparado ao Brasil: lá havia a expectativa real de alcançar o socialismo e por vias democráticas. Era a chamada via chilena para o socialismo. Esta experiência foi altamente marcante para a trajetória da Fração, continuada pelo MEP. No Chile, os exilados da FB tinham proximidade e afinidade política com o Movimiente de Izquierda Revolucionária (MIR), dirigido por Miguel Enríquez ${ }^{91}$. A empatia advinha do fato do MIR defender o caráter socialista da revolução chilena, além de se colocar como ponta de lança para enfrentar as agressões fascistas do grupo Patria y Libertad. Por outro lado, o MIR foi altamente influenciado pelos ecos da revolução cubana. O intelectual e militante Ruy Mauro Marini, por seu turno, manteve relações próximas com o MIR durante sua estadia no Chile.

Em terras chilenas, os exilados da Fração editaram o jornal Campaña, publicado em espanhol. Foram ao todo 25 números. O primeiro, em setembro de 1972. O último, outubro de 1975. Um dos responsáveis pela publicação foi Nilton Santos, que acompanhou o fim do governo Allende e o golpe militar de Augusto Pinochet. Com a vitória do golpismo, Nilton, assim como outros milhares de militantes de esquerda, foram levados ao Estádio Nacional, de onde muitos não saíram. Nilton 
conseguiu escapar para França, de onde continuou organizando uma espécie de célula internacional da Fração e, posteriormente, do MEP. Lá, foi editada a revista Brasil Socialista, em parceria com a POLOP e o $\mathrm{MR}^{92}$.

Ainda no Chile, foi formado o Comitê Brasileiro de Mulheres, no qual participavam militantes da Fração, do PCB e de outras organizações, além de algumas mulheres sem vínculo com algum grupo de esquerda. O principal objetivo do grupo era denunciar a ditadura militar brasileira. Ainda que temas feministas surgissem, não eram o foco do debate. Com a queda do Allende, como anunciado fora, o Comitê Brasileiro de Mulheres no Exterior, assim como a redação do jornal Campaña migraram para Paris, de onde continuaram a vida política.

Mulheres militantes da FB articuladas no Grupo Brasileiro de Mulheres Revolucionárias lançaram um documento chamado Por uma tendência feminina e revolucionária, em setembro de 1975, o qual conclamava a criação de um coletivo autônomo de mulheres com base na luta de classes $^{93}$. Como desdobramento dessa experiência, surgiu, em 1976, o Círculo de Mulheres Brasileiras em Paris, o qual veio exercer influência fundamental no feminismo brasileiro.

Uma das militantes da Fração Bolchevique presente neste contexto, Regina Carvalho aponta que o objetivo da iniciativa era discutir as questões feministas em uma perspectiva socialista. A ideia consistia em aproximar novas militantes e fazer propaganda do socialismo. Não distante da formulação clássica da FB, ou seja, aquela que orientava a formação da vanguarda socialista na luta contra a ditadura, Regina coloca que a prioridade continuava a ser a formação do partido revolucionário ${ }^{94}$. Esta orientação logo encontrou resistência por parte de mulheres de outras organizações e também de algumas não ligadas aos grupos marxistas. 92 Harnecker, Marta. O sonho era possível: a história do Partido dos Trabalhadores narrada por seus protagonistas. São Paulo. Casa América Livre/ MEPLA, 1994. Pg. 151.

93 Menegozzo, Carlos Henrique Metidieri. Fração Bolchevique (1970-1976). São Paulo, fev. 2008 (mimeo). Pgs. 2-3.

94 Natália de Souza Bastos. O círculo de mulheres brasileiras em Paris: uma experiência feminista no exílio. Pg. 03. Ver em: http://www.snh2011.anpuh.org/resources/rj/Anais/2006/conferencias/Natalia \%20de\%20Souza\%20Bastos.pdf 
Criticavam a instrumentalização do feminismo para fins particulares de grupo. Com o tempo, todavia, a experiência do feminismo francês, do vécu ${ }^{95}$, dos debates feitos no interior das organizações marxistas francesas, refinaram a visão feminista frente ao desafio socialista. De prática subordinada à estratégia geral, o feminismo torna-se parte constitutiva da estratégia, uma vez que a opressão vivida pela mulher é, mediante o patriarcado, um elemento de sustentação do sistema capitalista ${ }^{96}$.

O Círculo Brasileiro de Mulheres passou a ser composto por militantes do MR8, do POC e da Fração (posteriormente, o MEP), além de mulheres sem vinculação. Com o tempo, o coletivo ligado ao- MEP começou a ser identificado como um grupo radical, que dava bastante ênfase na questão da sexualidade e defendia com veemência a auto-organização das mulheres. O Círculo se organizava através de grupos temáticos, como educação, sexualidade, aborto e contracepção, maternidade, imprensa feminista, trabalho e teatro. Mensalmente, reuniam-se em assembleia geral, na cité universitaire ${ }^{97}$.

As atividades do Círculo Brasileiro de Mulheres diminuem de intensidade a partir de 1978 e, de fato, se encerra com a aprovação da Lei da Anistia, no segundo semestre de 1979. Muitos dos e das militantes voltaram ao Brasil. Não há dúvidas que essa experiência foi muito marcante para o feminismo brasileiro. Fundamental notar a participação de destaque das mulheres militantes da FB/MEP.

\subsection{Nova Luta}

Ao mesmo tempo em que a Fração estruturou sua atuação no exterior, no

95 Prática feminista que consiste no compartilhamento das experiências individuais com a finalidade de acolher a depoente e, ao mesmo tempo, politizar as questões do cotidiano.

96 Carmargo, Ayla. Nas origens do movimento feminista revisitada no Brasil: o círculo de mulheres de Paris. Anais do I Simpósio sobre Estudos de Gênero e Políticas Públicas, ISSN 2177-8248. Ver em: http://www.uel.br/eventos/gpp/pages/arquivos/8.AylaCamargo.pdf.

97 Bastos, Natália de Souza. Círculo Brasileiro de Mulheres Brasileiras em Paris: uma experiência feminista no Exílio. In: Encontro Regional de História, 12., 2006, Rio de Janeiro. Anais... 2006. Pgs. 34. 
Brasil os trabalhos começaram a ser reerguidos, após o vendaval da repressão. A principal ferramenta usada para fazer o trabalho de massa era o jornal Nova Luta ${ }^{98}$. Sua circulação era restrita, dado o contexto de clandestinidade. A distribuição dava-se de mãos em mãos, como veículo de debate com possíveis novos militantes, muito embora houvesse a prática de "esquecê-lo" em banco de ônibus ou em pontos estratégicos de universidades como maneira de agitação. Este periódico circulou entre 1972 e 1980. Foram 25 números, mais algumas edições especiais. O Nova Luta apresentava as visões de fôlego da Fração Bolchevique e, posteriormente, do MEP. O jornal seguia um certo padrão jornalístico. Sempre iniciado com o mote na luta contra a ditadura, formar a vanguarda socialista, apresentava denúncias das violações cometidas pela ditadura militar, destacava as lutas - sobretudo as sindicais e operárias, mas também as iniciativas do movimento estudantil e a luta no campo -, apresentava reflexões acerca da conjuntura política e, por fim, algum debate a respeito da questão socialista. A evolução do Nova Luta ilustra a própria evolução do pensamento da Fração ${ }^{99}$.

Vale aqui uma pequena imersão nas páginas do periódico para revelar, por dentro, o que pensava a Fração entre 1973 e 1975.

A orientação de sempre caracterizar a ditadura como o regime orientado a fazer política em nome dos andares de cima da sociedade baliza a linha do jornal e aparece em debate publicado em janeiro de $1973^{100}$. As ideias de que o movimento sindical é um espaço para a luta revolucionária, posto que lá se encontram os trabalhadores e suas lutas espontâneas, e o movimento estudantil como um aporte também para a luta dos trabalhadores estão presentes na edição. Merece destaque a

98 Conseguimos a coleção incompleta do Nova Luta digitalizada no Cedem (Centro de Documentação e Memória), na coleção doada por Ceice Kameyama.

99 Aqui foi feita uma opção metodológica. Entre o período 1973-1975, poucos documentos retratam a atuação militante da Fração. Além disso, como o grupo era estanque, ou seja, quase ou ninguém possuía um mapa de informações, é difícil desvendar o que fazia toda a Fração. Optou-se por discutir esse período através da análise do jornal, uma vez que retrata o que o grupo pensava sobre os fatos.

100 Nova Luta, №3, janeiro de 1973. In: DOC 857, DARF, FB 02-01 (Arquivo Municipal do Rio de Janeiro). 
avaliação a respeito do papel da igreja Católica, que passou a ser lugar privilegiado de denúncias dos crimes políticos cometidos.

Em março de $1973^{101}$, discutia-se o imperialismo no contexto de crise internacional. No plano nacional, falava-se sobre como deve ser o comportamento do revolucionário na prisão, além de algumas denúncias contra o regime. A Fração apresenta um debate a respeito da relação entre o governo da Unidade Popular e a noção de governo de transição ${ }^{102}$. A Unidade Popular era desenhada como uma experiência exitosa, cujo sucesso final dependeria de uma estratégia assertiva. A construção da ação comum entre partidos e frentes, com destaque para os partidos comunistas e socialistas, com amplo enraizamento social, permitiria o acúmulo de forças necessário para vencer as eleições. No entanto, as tarefas colocadas para o governo, tais como a reforma agrária, políticas de distribuição de renda e estatizações, ao lado da própria ira da oposição de direita, em algum momento, levariam a um choque, no qual somente um lado poderia consagrar-se vitorioso. Esse cenário de impasse estava presente no interior do conceito de governo de transição.

Logo, o sucesso da Unidade Popular dependeria de suas condições de superar o estágio de governo nos marcos da democracia liberal em direção ao socialismo.

Junho de $1973^{103}$. A foto de capa ilustra uma manifestação contrária à ditadura argentina. Algumas denúncias políticas - sempre constantes no jornal - são apresentadas, com destaque para a censura ao jornal Opinião e para a missa da morte do estudante Alexandre Vannuchi Leme, aluno de geologia da Universidade de São Paulo, militante da ALN, assassinado pela repressão. Seu nome batiza o Diretório Central dos Estudantes da USP, desde a refundação da entidade em março de 1976. A censura é apresentada como uma ferramenta da ditadura para "acalmar" o

101 Nova Luta, №4, março de 1973. In: DOC 857, DARF, FB 02-01 (Arquivo Municipal do Rio de Janeiro).

102 Mais adiante, serão melhor apresentadas as compreensões dos conceitos de governo de transição e frente única.

103 Nova Luta, N5, junho de 1973. 
povo brasileiro. Em resposta, o jornal brada que as mordaças não calarão a voz do povo trabalhador e chama por liberdade, liberdade e mais liberdade.

A morte de Vannuchi acende o movimento estudantil. Uma reportagem dá destaque ao evento, ao passo que apresenta uma visão do papel do movimento. $\mathrm{O}$ jovem militante foi assassinado em 17 de março. No dia 30, houve uma missa, na catedral da Sé, que contou com a participação de seis mil pessoas. A cerimônia religiosa foi também um ato de protesto. A violência do regime expressa no assassinato e a explicação farsesca da ditadura insuflaram reações. O movimento estudantil, atordoado desde o recrudescimento do regime em 1968, conseguiu retomar sua atuação com assembleias e encaminhamentos de denúncias do regime. Para a FB, o movimento continuava fraco e deveria se fortalecer para servir de linha auxiliar da luta dos trabalhadores contra a ditadura. Essa visão instrumental do movimento estudantil perpassa os anos da Fração. Ainda assim, reconheciam que a luta dos estudantes criava um ambiente mais favorável para a resistência.

É comum no Nova Luta cartas e mensagens publicadas de fora, fazendo-se ouvir vozes vítimas da opressão - operários, gente comum que apresenta alguma denúncia, militantes. Nesse exemplar, há uma carta apócrifa destinada ao trabalhador brasileiro. Este recurso de apresentar uma voz externa, vinda de baixo, se apresenta como uma tentativa de diálogo direto com o leitor, uma forma sutil e subjetiva de busca pelo convencimento. Nela, diz:

\begin{abstract}
tu és com os nossos irmãos quase todo o Brasil; és tu quem cria os alimentos e morre de fome; és tu que veste a população e vive de tanga; dás o soldado para defender a pátria e ela te esquece, porque ela não é tua, mas dos patrões que governam segundo os interesses deles; dás o guarda para a polícia e a polícia te esmaga, porque ela é um instrumento usado pelos ricos, exploradores do povo, para te manter escravizado; dás a esmola para a igreja e a igreja te pede resignação, em nome de Cristo. [...] Mas Cristo foi um rebelde e por isso subiu à cruz; foi Cristo quem disse ser mais fácil um camelo passar pelo fundo de uma agulha que um rico entrar no reino do Céu $u^{104}$.
\end{abstract}

Neste pequeno trecho, há uma gama de concepções anticapitalistas historicamente construídas.

104 Nova Luta, N5, junho de 1973. 
A questão do papel do indivíduo na história é discutida no artigo O herói e a luta de classes, de autoria do jornal. A trajetória não stalinista do grupo é vista nessa reflexão, pois ataca centralmente o culto ao indivíduo e a ideia do homem salvador, embora ressalte a importância da vanguarda revolucionária. Critica quem se coloca acima da classe operária e não à sua frente. Apresenta a necessidade de reavaliar o heroísmo, pois a classe operária ficou sem direção em razão do mesmo. Esta visão é distinta de outros grupos. Marighella, em seu Mini-manual do guerrilheiro urbano ${ }^{105}$, apresenta o militante comunista (no caso, o guerrilheiro) como alguém capaz de desenvolver várias qualidades - de caráter físico e intelectual. O guerrilheiro deve ser alguém dotado de uma especialidade interna. Existe um heroísmo nessa formulação, negado pela Fração Bolchevique. Afastar de vez o herói e sua sombra do palco da história é o que defende o texto. Apenas para registro, Carlos Marighella, a despeito das divergências em relação ao militarismo, e é neste campo que a crítica ao herói está colocada, é visto com imenso respeito e como um verdadeiro revolucionário pela Fração Bolchevique.

De todas as datas comemorativas da esquerda, o Primeiro de Maio é a mais rememorada. Nesta edição do Nova Luta, o evento é chamado de grito de guerra do proletariado de todo o mundo. O histórico da data é apresentado. Foi em 1886, nos Estados Unidos, quando estoura uma greve de 350 mil operários em luta por redução da jornada de trabalho, em Chicago. Oito lideranças são presas, acusadas de um ataque a bomba, e condenadas à morte: Augusto Theodore Spier, Adolfo Filher, Jorge Engel, Albert Parsons, Luiz Lingg, Miguel Shwab, Oscar W. Neebe e Samuel Filden.

Diante do tribunal, as palavras dos acusados ficaram registradas. Disse Spier:

ao dirigir-se a este tribunal, faço-o como representante de uma classe ante os de outra classe inimiga, e começarei com as mesmas palavras de um personagem veneziano, pronunciadas há cinco séculos atrás ante o Conselho dos Dez, em ocasião semelhante: 'minha defesa é a vossa acusação; meus pretensos crimes são a vossa história"'.

Já Filden falou que:

105 Disponível em: https://www.documentosrevelados.com.br/wp-content/uploads/2015/08/carlosmarighella-manual-do-guerrilheiro-urbano.pdf 
se quereis a minha vida por invocar os princípios do socialismo, como eu entendo e creio honradamente que os invoquei em favor da humanidade, dou-a contente, e creio honradamente que o preço é insignificante ante os resultados grandiosos do nosso sacrifício.

Essas referências são caras ao conjunto da esquerda. Interessante notar que a defesa do espírito de sacrifício não se confunde, para o Nova Luta, com o heroísmo deslocado da classe trabalhadora.

Comentários acerca dos acontecimentos internacionais aparecem em praticamente todos os números do jornal. Este $5^{\circ}$ número termina com a queda da ditadura na Argentina. Em análise semelhante ao regime militar brasileiro, apontavam que os militares ${ }_{\perp}$ ao oporem pátria a socialismo, tornaram-se os principais defensores do regime de exploração. Após sete anos da deposição de Organia, os peronistas vencem as eleições, embora tenha havido o fortalecimento do peronismo de direita. Sua importância consistia em encampar as principais reivindicações políticas dos setores avançados, em especial a bandeira das liberdades. A posse de Câmpora se deu através de acordos com militares. No entanto, a pressão popular garantiu que o novo governo fizesse a anistia, legalizasse o partido comunista e abrisse relação com Cuba. O NL aponta que o novo regime só pode sobreviver com a pressão popular. Termina com a chamada por uma América Latina Socialista! Aqui, percebe-se o forte sentimento latinoamericanista.

Treze de setembro de $1973^{106}$. Para Allende:

Meu camarada! O teu túmulo é toda essa América Latina ultrajada. A História exigiu tua vida e tu sorrindo a deu. Teu coração morto pulsa dentro de meu peito latino-americano.

Outubro, $1973^{107}$. Allende morreu de arma na mão! A questão chilena é muito importante para a trajetória da FB. Dedicam a ela muita discussão. O sétimo número do Nova Luta, com destaque, reflete sobre o golpe militar no Chile. O proletariado chileno morre pelo socialismo e contra a tirania: eis o título escolhido do texto que relata toda sorte de violências movida pela ditadura contra o Chile insurgente. Os

106 Edição especial do Nova Luta em homenagem a Salvador Allende.

107 Os debates trazidos neste bloco referem-se à edição Nº7 do Nova Luta, outubro de 1973. 
resultados são, de fato, catastróficos, apresentando por volta de 40 mil vítimas ${ }^{108}$. Do ponto de vista internacional, representantes de instituições norte-americanas, como o City Bank, comparam o processo chileno ao brasileiro e celebram a "estabilização política". Membros do governo militar são enviados aos centros capitalistas em busca de investimentos. Enquanto isso, o Chile, dividido, vive uma guerra civil. O Nova Luta comunga da ideia do recuo estratégico para rearticular as forças de resistência em torno de um comando único político/militar. A FB, mesmo distante das posições militaristas no Brasil, reconhecia o cenário de guerra civil no Chile e a legitimidade da defesa com armas em punho. No fim, frustrados com a derrota do governo socialista, levantam a palavra de ordem paredão para os militares assassinos. Essa palavra de ordem é a mais radical vista em todos os números do periódico.

O mundo reagia contra a selvageria comandada por Pinochet. A solidariedade internacional é o assunto abordado. Os países comunistas rompem relação com o Chile. Em emissão diária para a América Latina, Moscou denuncia os crimes cometidos. Holanda e Bélgica suspendem ajuda econômica. Passeatas em diversos países pedem a libertação de Luís Corvalán, secretário-geral do Partido Comunista. Em Roma e Milão, cem mil pessoas ocupam as ruas. Na França, cinquenta mil. Reúne-se, na Finlândia, a Conferência Internacional de Solidariedade para com o Povo Chileno, que congregou delegados de cinquenta países. A Argentina, mais próxima, foi palco de muitas manifestações. As diversas juventudes (Juventude Peronista, Juventude Radical, Juventude do MID, a Federação Juvenil Comunista, a Juventude Intransigente, a Juventude Revolucionária Cristã, o Ateneu para uma nova Geração) assumiram o protagonismo da luta em solidariedade. Nas ruas, cantavam atenção, atenção, toda Cordilheira vai servir de paredão.

Para além do registro das ações de solidariedade, o mais relevante é a reflexão apresentada, no conteúdo do texto, que busca entender as razões do golpe. O que fracassou não foi a esquerda no Chile, diziam, mas as ilusões na democracia

108 Estima-se que a ditadura no Chile matou 40 mil pessoas, despareceu com três mil e 200 mil foram exilados. Veja relatório da Comissão Vlalech sobre a violência de Estado durante o governo Pinochet:https://bibliotecadigital.indh.cl/bitstream/handle/123456789/600/Informe-Valechll.pdf? sequence $=5$ 
burguesa, a crença de que se poderia chegar ao socialismo com o consentimento dos adversários.

A experiência chilena, como já foi dito, é muito marcante no pensamento do MEP, de modo que em vários momentos ela será resgatada e usada como fio da meada para ilustrar reflexões, sobretudo de ordem estratégica. Tópicos como a disputa do Estado, a construção de um governo dos trabalhadores, os limites da institucionalidade são evocados a partir da rica e marcante trajetória da Unidade Popular chilena.

Nessa direção aponta o artigo "Sangue operário no Chile, uma nova lição". Preocupados com o resgate histórico, explicam que a divisão entre os partidos Democrata Cristão e o Nacional permitiu o crescimento de forças progressistas, com destaque para os Partidos Comunista e Socialista - os principais da Unidade Popular. A UP conquistou a maioria do proletariado. Seu programa apontava para a transição chamada "via chilena para o socialismo", ou seja, a via democrática para o socialismo $^{109}$. No entanto, o governo, segundo a Fração, que deveria ser visto como uma ponte, uma ferramenta para o acúmulo de forças, foi confundido com o próprio poder. Tornou-se um fim em si mesmo. O problema, portanto, desenhava-se nos traços da ilusão reformista. A reforma agrária e as nacionalizações avançaram radicalmente, medidas que aumentaram a adesão dos setores populares ao governo. Ocorre que o caráter de classe do Estado fez com que a burguesia não perdesse o poder político. Mesmo com a fragilidade de atuação dos partidos das classes dominantes no parlamento - leia-se o Democrata Cristão e o Nacional - as vontades políticas dos setores de cima da sociedade eram canalizadas por braços do Estado, como o judiciário e as forças armadas. O conflito nas ruas também mobilizou a direita através do grupo fascista Pátria e Liberdade.

Enfim, este enredo explicita o erro político da UP. A síntese derradeira da derrota se traduz na afirmação que diz que a quantidade de votos numa eleição

109 Aggio, Alberto. Democracia e Socialismo, A experiência chilena. Editora Annablume. São Paulo, 2002. Pg. 50. 
burguesa não tem importância nas batalhas decisivas do proletariado.

O debate acerca de questões internacionais segue, com ênfase no antiimperialismo. Dois artigos vão nessa direção. O primeiro, Oriente Médio socialismo ou imperialismo. O expansionismo israelense é denunciado, passando pela sua origem em 1948, pelo episódio da guerra dos seis dias, em 1967, mais ainda pela continuidade da apropriação indevida não só dos territórios palestinos, como também da Jordânia, da Síria e do Líbano. Esse expansionismo, com apoio norteamericano, estimulava algum grau de aproximação entre os países árabes. Ao enfrentar o imperialismo, a luta de classes acabava sendo estimulada em cada país. Eis o ponto. A questão nacional frente ao imperialismo poderia ser um abre-alas para o socialismo.

Nessa mesma direção, discute-se as posições de Fidel Castro na IV Conferência dos países não alinhados, realizada na Argélia. Fidel, em fala citada, ao denunciar o golpe militar brasileiro, reafirma a centralidade da luta antiimperialista e diz que a URSS não se enquadra nos países imperialistas. A polarização geopolítica gira em torno do imperialismo contra o socialismo e governos progressistas. Mais: o Nova Luta é explícito em relação ao apoio à URSS, muito embora reconheça limites e contradições. Assim dizem:

colocar no mesmo plano a crítica aos EUA e à URSS é nivelar o baluarte da reação mundial e principal base das ditaduras de direita com um país que, bem ou mal, apoia movimentos revolucionários, governos progressistas e constrói uma sociedade sem exploração do homem pelo homem. É dividir as forças contra o inimigo comum, é fazer o jogo do imperialismo.

\section{E ainda citam parte da fala de Fidel Castro}

Não podemos esquecer de que as armas que Cuba usou para defender-se dos Estados Unidos imperialista, de que as armas usadas pelos árabes e vietnamitas na sua justa luta contra as agressões do imperialismo, de que as usadas pelos africanos contra o colonialismo português vieram dos países socialistas, principalmente da União Soviética. Inventar um inimigo, só pode ter um propósito: unir-se ao inimigo verdadeiro.

As longas citações justificam-se pela importância do tema. O alinhamento da 
FB/MEP à Cuba de Fidel Castro e à defesa da URSS são traços de imensa relevância na organização. Mesmo vindo de um tronco da esquerda não stalinista, essas opiniões acima não são exatamente comungadas por grupos trotskistas.

Voltando às questões nacionais, o papel político das Forças Armadas no contexto das ditaduras é analisado no artigo Hienas vorazes. Falando em nome do Brasil na Conferência dos Exércitos americanos, realizada no início de setembro, o General Bruno Borges Fortes reafirma o jargão conservador em moda ao apresentar que o ponto em comum entre as Forças Armadas é o combate ao comunismo internacional. Os regimes liberais, na opinião do NL, foram insuficientes para garantir o regime de exploração e conter os movimentos da classe trabalhadora. Nessa fresta, entram os militares como verdadeiros partidos políticos da burguesia.

Países, como o Brasil, tornam-se subimperialistas, agem como entreposto do imperialismo, ferramenta local da pilhagem internacional. A intervenção do subimperialismo brasileiro dava-se não somente na área econômica, mas também como patrocinador de golpes e exportador de técnicas de tortura. Ajudou diretamente a chegada ao poder de Banzer na Bolívia, por exemplo. Prestaram ajudas ao regime chileno e ao uruguaio. Mesmo Fleury, assassino de Marighella, teria sido enviado ao país mais ao sul do continente para ensinar técnicas de tortura. A noção de que os militares são um partido político garantidor do regime de exploração é um elemento central da análise da ditadura.

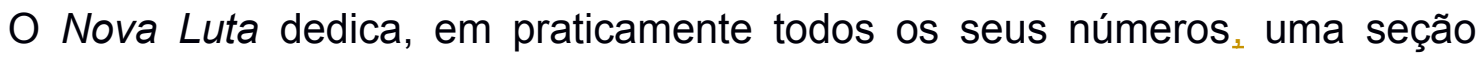
especial que relata as lutas. Dão ênfase, sobretudo, aos pequenos exercícios de resistência operária. Na edição $N^{0} 7$, a seção Resistir à Ditadura apresenta os movimentos de resistência de maneira difusa. Algumas notas: relatos de operários que passam fome na Telefunken; eleição no sindicato dos metalúrgicos da Guanabara; deposição do presidente combativo do sindicato dos químicos também da Guanabara; saque à Cobal (companhia de abastecimento no RJ). O movimento estudantil, na UFF e na UFRGS, aparece, embora ameaçado constantemente pelo decreto 477, o qual permitia a expulsão de "agitadores". São exemplos das lutas que 
rondavam os radares da Fração Bolchevique. Citá-las justifica-se pelo esforço de reconstituir o pensamento da organização.

O sétimo número termina com uma homenagem a Pablo Neruda, comunista e poeta. Citam um poema inspirado na Guerra Civil Espanhola, chamado España em El Corazón, que serve à America Latina dos anos 1970. Eis um trecho:

\author{
Generais \\ Traidores: \\ Olhai a minha casa morta, \\ olhai a Espanha arrebentada. \\ mas de cada casa morta sai metal ardendo \\ em vez de flores, \\ mas de cada buraco da Espanha \\ sai Espanha, \\ mas de cada criança morta sai um fuzil com olhos, \\ mas de cada crime nascem balas \\ que vos acharão um dia \\ o lugar do coração.
}

Dezembro de $1973^{110}$. Uma foto da Rússia revolucionária em outubro de 1917 com a silhueta do rosto de Vladimir llich Lênin ilustra a capa. O custo de vida, a resistência no campo, a Revolução Russa e a guerra de independência de Guiné Bissau são os principais temas abordados.

A questão que envolve salário e inflação ganha relevo no seguinte sentido: se a ditadura foi instaurada para garantir o regime da super-exploração, essa situação obrigatoriamente aparece em números. O Nova Luta entendia que a ditadura 110 Nova Luta, №8, dezembro de 1973. 
escamoteava os índices reais de inflação. Os ditadores, em busca da preservação dos lucros empresariais, garantiam a inflação a partir do controle dos salários. $\mathrm{O}$ governo apresentou, no tempo correspondente ao número desta edição, a expectativa de aumento do custo de vida em $12 \%$, o que não corresponde ao dia a dia do trabalhador. A ditadura entende de economia quando esta consegue funcionar com as patas dos soldados em cima do trabalhador, diziam. Gastos com a alimentação consomem a maior parte do salário mínimo. Entre janeiro e outubro, houve aumento de $87 \%$ da cesta básica. Enquanto isso, o aumento do salário mínimo é anunciado em $16 \%$ (esses dados se referem à grande Rio). Esse descompasso permite o "milagre". Os baixos salários compõem o pacote de crescimento econômico. Ao mesmo tempo em que o comércio exterior e o endividamento são fundamentais para a política econômica. A estabilidade política da ditadura, nesse sentido, vem da desorganização dos trabalhadores, da repressão e dos altos lucros.

Há, no entanto, um conflito entre a ditadura e as classes dominantes a respeito dos preços. O governo buscava controlar a inflação para fazer com que o produto brasileiro fosse competitivo no mercado internacional, de modo a estabelecer um patamar que permitisse o investimento e o financiamento externos. Ao passo que a burguesia pressionava por preços ainda maiores. Cabia ao "mágico" Delfim Neto encontrar a solução. No entanto, por trás da técnica existe uma realidade social concreta, na qual os limites para soluções tornam-se mais estreitos.

O crescente aumento do custo de vida descrito acima tem a ver com as grandes cidades, ainda que no contexto de modernização conservadora, que, por conseguinte, afetava o campo. A situação do capitalismo no campo mostrava novamente a situação de miséria dos trabalhadores. Essa é a continuidade do debate. O campo brasileiro carrega sinais claros de atraso. Isso ocorre em razão da burguesia ganhar dinheiro com um modelo arcaico, concentrador de terra, monocultor e voltado para a exportação. Esse contexto demonstra que a luta pela reforma agrária estaria no campo de uma burguesia liberal esclarecida, embora quando incorporada pela esquerda esbarre nos limites da ilusão reformista. Sem embargo, o projeto modernizador da ditadura interessou-se por aumentar a produtividade do campo e 
conectá-lo à indústria. Ainda em 1964, Castelo Branco aprovou o Estatuto da Terra, o qual previa a criação do IBRA (Instituto Brasileiro de Reforma Agrária) e o INDA (Instituto Nacional de Desenvolvimento Agrário). Médici, em 1970, criou o INCRA (Instituto Nacional de Colonização e Reforma Agrária) para substituir os dois anteriores. Seu objetivo era "expandir a fronteira agrícola", ou seja, aumentar o latifúndio. O Plano de Integração Nacional (PIN), que buscava unir a Amazônia ao país, e o PROTERRA, o qual, por sua vez, tentava "facilitar" o acesso à terra, no sentido de fortalecer o capitalismo monopolista no campo, aproveitando-se da demanda por produtos agropecuários e dos altos preços no mercado externo ${ }^{111}$.

As facilidades apresentadas pela ditadura são aproveitadas sobretudo por companhias agrárias, que investem na produção ou especulam com a terra. $\mathrm{O}$ trabalhador rural é escanteado. Ao mesmo tempo, o avanço da mecanização da produção, em especial no Rio Grande do Sul e em São Paulo, gera desemprego e êxodo rural. Não à toa, todo esse processo agressivo de modernização do campo tem gerado aumento expressivo do conflito. São Félix, em Mato Grosso, e Paragominas, no Pará, além de outros Estados, são exemplos. O NL propõe como saída política a união entre operários e camponeses para combater a exploração na cidade e no campo, de modo a socializar as grandes propriedades - fazendas, bancos e empresas. A compreensão é a de que a luta operária pode abrir horizontes para a massa oprimida no campo. A própria luta armada poderia generalizar-se sob influência proletária. Enfim, a defesa da luta armada no campo contra jagunços e fazendeiros aliada às mobilizações operárias unem camponeses e trabalhadores na luta contra a ditadura.

Nessa edição, há várias pequenas denúncias contra o regime. O generalinterventor em Santos, Clóvis Bandeira Brasil, foi advertido por Médici por excesso de corrupção, denunciada pela oposição na Câmara dos Vereadores. Enquanto isso, no outro lado do Atlântico, uma exposição de produtos na Bélgica, patrocinada pela ditadura, foi alvo de inúmeros protestos. Em Milão, uma expedição acolhida por Laudo Natel, composta por 69 nomes, dentre os quais Teobaldo de Nigris e Papa Jr. 111 Importante frisar que esse modelo interpretativo é o que consta no jornal. 
presidentes da FIESP e da Federação do Comércio - acabou em um vexame. Após bebedeira generalizada, os membros da delegação arrumaram confusão e foram expulsos do hotel.

Denúncias de ordens criminal e moral continuavam sendo feitas. O filho do ministro da Justiça, Alfredo Buzaid, foi acusado de assassinar uma criança em decorrência de um conflito por dinheiro do tráfico de drogas. Sérgio Paranhos Fleury foi parar no banco dos réus, acusado de matar um traficante. Nomes como o do governador Laudo Natel saíram em defesa do torturador. Esse tipo de denúncia cumpria o papel de revelar a ditadura não somente como um regime autoritário, mas, também, um regime imoral, formado por pessoas imorais.

A perseguição à igreja católica progressista é relatada, em Goiás e Recife, assim como a denúncia dos crimes da ditadura feita pelo jornalista norte-americano Jack Anderson, que expôs trinta mortes ocorridas no ano, mais a lista com o nome de torturadores.

Irregularidades no INPS, que consome $8 \%$ do salário, e o aumento da exploração nas montadoras são retratados. De 1971 a 1972, o número de operários da Volks, General Motors, Ford e Mercedes passou de 66292 para 73661, aumento de $11 \%$, enquanto os lucros declarados foram de 507 para 908 milhões, alta de $92 \%$.

A questão da sucessão presidencial é apresentada com um teor de humor. $\mathrm{O}$ trecho foi extraído do jornal Manifesto ${ }^{112}$. Chama-se Farsa em seis atos. Duração: dez meses.

\footnotetext{
$1^{\circ}$ ato: quem será o novo presidente. Ouve-se apenas bastidores, mas sabe-se que virá de verde-oliva.

$2^{\circ}$ ato: indicado o presidente. Ernesto Geisel. Desconhecido, a plateia boceja.

$3^{\circ}$ ato: oposição. Parece um monte de baratas tontas. Aparece o nome de Ulysses Guimarães. Também desconhecido, a plateia volta a bocejar.

$4^{\circ}$ ato: convenção da Arena. 800 bobos alegres fingem escolher um nome. Petrônio Portella diz
}

112 O jornal Manifesto foi um dos mais importantes da imprensa alternativa. Essa experiência será abordada em capítulo posterior. 
que a "Arena sabe da importância de seus préstimos para o aperfeiçoamento do regime democrático". Assustada, a plateia acorda com a cara de pau do ator.

Intervalo (a oposição poderá fazer campanha?).

$6^{\circ}$ ato: o colégio eleitoral será representado em janeiro de 74. Cansada da farsa, a plateia vai embora mais cedo, sabedora do final da história.

Na seção sobre o mundo, o destaque é dado para a primeira derrota da ditadura portuguesa na África. Explica-se. O capitalismo frágil português não permite formas modernas de dominação, como as utilizadas pela França, Bélgica e Inglaterra, de modo que seu caminho de controle foi por via estritamente militar. $O$ que determina a política de Portugal na África é a situação interna do país. A ideologia fascista portuguesa - levada adiante em 1932 por Salazar e continuada com Marcello Caetano - se baseava no capitalismo comercial e no "valor de sua raça". Isso dificultava a integração ao mercado moderno. No entanto, por ser a colonização ultraviolenta na África o calcanhar de Aquiles da ditadura salazarista, os negros assumiram a vanguarda da luta contra o fascismo português. Luta essa que é fundamental para a luta dos trabalhadores portugueses contra o regime ditatorial. Em 1956, forma-se o PAIGC (Partido Africano de Independência da Guiné e Cabo Verde), sob a liderança de Amílcar Cabral. Em 1963, dá-se início à luta de guerrilha. Já em 1972, ocorre eleição para a primeira Assembleia Nacional. No dia 20 de janeiro, Amílcar é assassinado. No dia 24, o PAIGC declara a Guiné Bissau independente. Em Angola e Moçambique, o Movimento de Libertação de Angola (MPLA) e a Frente de Libertação de Moçambique (FRELIMO) desfecham ataques ao imperialismo português. Enquanto isso, o regime salazarista busca apoios internacionais, em especial- da Inglaterra. A reação popular em nível internacional à barbárie cometida por Portugal na África, que coleciona relatos inacreditáveis de selvageria, cresce. Vale notar que a FB/MEP, embora não possuísse a tradição de ser filiado a um organismo internacional, sempre buscou localizar sua visão na perspectiva panorâmica das grandes lutas travadas pelos povos.

Notas sobre o movimento estudantil, que volta a ser problematizado no NL. É apresentado como ponta de lança contra a ditadura em vários países. Sua luta tem 
ressonância, embora haja contradições no interior do seu funcionamento, sobretudo nos países subdesenvolvidos. Nesses, a classe média, que antes tinha sua segurança material baseada na pequena propriedade, torna-se instável com a chegada do capital estrangeiro monopolista. Para resgatar a estabilidade e poder crescer na hierarquia social, busca-se o caminho da formação técnica e universitária. As instituições de ensino, também sufocadas pelas pressões do capital a produzir conhecimento para a reprodução da ordem capitalista, limitam as possibilidades de estudo, freiam a criatividade.

Dessa situação, surge uma frustração na classe média, que não presencia sua subjetividade nem suas pretensões trabalhistas serem atendidas pelo padrão de funcionamento universitário. A radicalização do movimento estudantil nasce dessas contradições. Isolado, o movimento dos estudantes tende a permanecer inócuo, porque preso na sua origem de classe pequeno burguesa. Cabe a ele, portanto, aliarse à classe operária, introjetar a ideologia proletária. Seu papel como formador de quadros para a construção do partido revolucionário é destacado, assim como para a denúncia do regime militar.

A memória da revolução russa encerra esse número, em comemoração à vitória de novembro (outubro no calendário russo). Citam Trotsky, em um comunicado sobre a liquidação da reação, para ilustrar o momento:

A grande ideia do poder da democracia operária e camponesa juntou-se às filas do exército e impôs sua vontade. De agora em diante, todo o país e o mundo se convencerão de que o poder soviético não é um fenômeno passageiro: o poder dos operários, camponeses e soldados é um fato indestrutível. A derrota de Kerensky é a confirmação do direito do povo à vida de paz e liberdade, à terra, ao pão, ao poder!

Encontra-se nos arquivos da Fração Bolchevique um documento, provavelmente de 1973, com o título Revolução socialista ou caricatura de revolução ${ }^{113}$. Este documento é a tentativa mais elaborada da FB de traçar sua compreensão da revolução socialista à luz dos principais acontecimentos históricos

113 O documento em questão foi encontrado na condição de suplemento especial do jornal Nova Luta. Sua localização, assim como os números do NL, se dá no CEDEM da UNESP. 
recentes. Com a experiência chilena como pano de fundo, o debate que se propõe é sobre a validade do marxismo-leninismo enquanto teoria científica de libertação do proletariado. $\mathrm{E}$ até que ponto a experiência chilena é produto do marxismo-leninismo. Apresentamos a seguir uma síntese do documento.

I - O imperialismo ${ }^{114}$ - que possibilitou o aceite de reivindicações operárias nos países centrais - e a difusão do marxismo criaram condições para a revisão da teoria revolucionária. Passou a reexistir uma polarização entre teoria revolucionária versus ideologia pequeno-burguesa. No entanto, dessa vez, a polarização surge clandestinamente, não de maneira transparente aos olhos daqueles que faziam parte da discussão. Nos séculos XIX e XX, o marxismo derrotou intelectualmente outras correntes de pensamento, como o anarquismo e o socialismo utópico. Agora, no interior do campo marxista, abordagens que questionam pontos centrais da teoria de Marx e Engels apareceram.

Com o triunfo do marxismo sobre as teorias pequeno-burguesas, o novo revisionismo passou a revelar-se por práticas políticas oportunistas. O que distingue $o$ marxismo das outras teorias é a necessidade da destruição violenta do Estado capitalista e a sua substituição pela ditadura do proletariado. Ou seja, a perspectiva efetivamente revolucionária. $\mathrm{O}$ caráter científico do marxismo, não idealista, reside nesse pressuposto.

Os reformistas buscavam uma sociedade superior através de reformas e da herança da democracia burguesa. O novo reformismo busca emplacar sorrateiramente esses pressupostos no interior do marxismo.

II - A segunda internacional faliu politicamente com a adesão ao reformismo por parte dos partidos social-democratas. A situação tornou-se irreversível quando estes apoiaram as burguesias de seus respectivos países na Grande Guerra interimperialista. Com a vitória da Revolução de Outubro, o movimento operário internacional passa a ter outro farol. A criação da Terceira Internacional, com sua

114 Os tópicos que seguem são uma interpretação do documento em questão. 
leitura assertiva do marxismo, sobretudo no que se refere à defesa da ditadura do proletariado e à caracterização do imperialismo como etapa superior do capitalismo, assume a autoridade política e revolucionária diante dos interessados em superar o capitalismo.

Com a tarefa de orientar o proletariado mundial para a luta de emancipação, a III Internacional busca elaborar uma estratégia para ação. No interior dessa estratégia, dois conceitos foram formulados: governo de transição e frente única.

A defesa da frente única foi apresentada em tese para o IV Congresso da Internacional, realizado em 1922. Consiste em uma frente de trabalhadores, que reúne membros de várias organizações políticas, mas com o predomínio dos comunistas, no sentido de fazer avançar as consciências mais atrasadas e, assim, fortalecer a luta proletária rumo à revolução. Essa frente não significa acordos eleitorais de cúpula. Significa uma oferta dos comunistas para todos os trabalhadores e se realiza, sobretudo, nas bases. Importante destacar que a frente única é distinta da frente popular, proposta pelo stalinismo, ao mesmo tempo em que difere da frente antiimperialista apresentada pela pequena-burguesia. A frente única é uma frente de trabalhadores.

Em consonância com esse conceito está o de governo de transição, tese também aprovada no IV Congresso. A ideia de governo de transição compreende que é possível existir um governo operário que ainda não desenvolva a ditadura do proletariado. Seria um governo de transição entre o capitalismo e o poder efetivamente das maiorias, o qual poderia mesmo ser alçado através de eleições parlamentares em dada circunstância específica. O principal objetivo deste governo é o de armar a classe trabalhadora e desarmar a burguesia. Por seu caráter operário, as consequências das ações leva a uma polarização crescente com a burguesia, podendo alcançar a guerra civil. Novamente, tais governos não são nem burgueses nem proletários, de modo que o seu desfecho só pode ser a vitória acachapante de uma classe sobre outra.

O governo de transição atua para desarticular as ferramentas de dominação da 
burguesia. Vira seu aparato de repressão para lado distinto de onde estiverem as maiorias do povo. Estimula a organização direta dos operários, embora não possa ser considerado um governo proletário por estar nos marcos da democracia burguesa. Esta ambiguidade faz com que o Estado deixe ser plenipotenciário comandado por uma classe para ser uma ferramenta da transição.

É possível afirmar que o MEP é tributário rigoroso dessas resoluções do IV Congresso e que as carregou em suas análises, na prática, até a sua dissolução em 1985. Toda orientação estratégica do MEP é pautada nos dois conceitos acima. Por isso, para o grupo, eles são de extrema importância. Mais ainda, carregadores desse legado, isso Ihes confere particularidade de pensamento e tradição no âmbito da esquerda brasileira.

III - Há no interior da URSS contradições que refletem ainda a existência da luta de classes. Isso não ocorre no campo político, onde a burguesia fora destronada; tampouco no econômico, no qual os ricos foram desapropriados. No terreno ideológico, ainda há espaço para a disputa. Esta afeta a direção política soviética.

O cenário internacional provoca mudanças profundas de linha política. A postura da Terceira Internacional altera-se com a ascensão do nazismo alemão no início da década de 1930. As resoluções do IV Congresso - governo de transição e frente única - são substituídas por outras orientações, a destacar as lutas democráticas e populares, alianças amplas com setores liberais da burguesia contra o fascismo e a perspectiva - que não deixa de ser um desdobramento dos dois primeiros elementos - da revolução por etapas. Em primeiro lugar, a luta democrática antifascista e, em segundo, a luta revolucionária socialista. O chamado etapismo embalou os partidos comunistas, em especial nos países subdesenvolvidos, por boa parte do século XX.

A Internacional passou a conceber o fascismo como o regime político da última fase do capitalismo, o imperialismo. Isso posto, grupos por mais que burgueses, dispostos a enfrentar o fascismo se colocavam, teoricamente, no campo anticapitalista. A noção de frente popular bebe nessa fonte. Justamente da brecha 
entre o governo de transição e a construção de democracias populares ressurge o reformismo. O papel histórico do proletariado é rebaixado. O episódio da Guerra Civil Espanhola é sintomático das contradições da nova política da Internacional. Optaram por não radicalizar o governo da República para não perder a aliança com setores burgueses contrários ao fascismo de Franco, o que gerou uma desmotivação política dos combatentes. O POUM (Partido Operário de Unificação Marxista), o qual atuou com destaque na Espanha insurgente, por sua posição distinta tanto do comunismo stalinista quanto do trotskysmo, era um exemplo a ser seguido, na visão do MEP. Para o jornal Nova Luta, a Terceira Internacional foi enterrada nos campos da Espanha, assim como a Segunda Internacional o foi nas batalhas da Primeira Guerra Mundial.

IV - O preâmbulo apresentado serviu para estabelecer paradigmas que distinguem a política marxista-leninista da política reformista. Isso posto, cabe avaliar novamente os erros de análise e concepção que levaram à derrota da Unidade Popular no Chile. Destaca-se a leitura idealista compartilhada por Allende de que seria possível alcançar o socialismo pacificamente e por meio das instituições burguesas. Para além disso, citam uma entrevista do próprio Salvador Allende a um periódico francês, em que ele afirma que a construção do socialismo por via da violência criaria um tipo de sociedade que os chilenos não se adequariam por sua tradição democrática. Os defensores da via pacífica criticavam as "formas autoritárias de governo". Para o Nova Luta, uma dessas "formas autoritárias" seria justamente a ditadura do proletariado, instrumento imprescindível para fazer prevalecer a vontade da maioria e consolidar a vitória da classe operária sobre a burguesia. Outro aspecto da visão idealista predominante da UP era a defesa da legalidade. Esta aparecia como cláusula pétrea. Ocorre, entretanto, que a defesa da legalidade em abstrato é um grave equívoco na medida em que desconsidera a luta de classes. Em um cenário de agudização do conflito social, as classes dominantes não tergiversam em romper com a legalidade. Exatamente isso que foi visto com o golpe militar comandado por Augusto Pinochet. O Nova Luta, nesse caso, alinha-se ao MIR, que defendia que o governo da UP deveria se preparar para o conflito armado e preparar 
caminhos para a mudança inspirados na experiência de Outubro.

Enfim, a centralidade da crítica ao caminho pacífico para o socialismo reside em um problema filosófico, em outras palavras, na substituição da concepção materialista e dialética da história pela idealista. O idealismo fez com que a UP negligenciasse o caráter de classe do Estado, o que levou o governo de Allende e sua base de apoio a não se prepararem para o momento do conflito, inevitável quando se trata de democratizar a riqueza.

V - Este documento de fôlego termina destacando a necessidade de se combater o reformismo nas fileiras do proletariado. Entendido como um subproduto da luta de classes da sociedade capitalista em sua fase imperialista, o reformismo é uma das ideias elaboradas pela pequena burguesia. Por sua origem de classe, esta elaboração não pode ser capaz de conduzir o proletariado no caminho de sua emancipação. Para fazer triunfar o marxismo-leninismo, cabe resgatar os clássicos, enriquecê-los com as novas experiências e se enraizar na classe trabalhadora com uma política revolucionária.

Essas teses, quase dispersas na oitava edição do Nova Luta, garantem lugar proeminente nas formulações da FB/MEP. Várias questões e opiniões muito relevantes derivam delas, como veremos mais a frente.

Março de $1974^{115}$. Fidel Castro ilustra a capa. O primeiro assunto abordado é o movimento espontâneo do proletariado e as tarefas dos operários conscientes. Diante do descenso da luta operária, as movimentações espontâneas que aparecem animam os combatentes. Os problemas econômicos avançam, o que naturalmente estimula reações dos trabalhadores. A burguesia para manter altas as taxas de lucro utiliza-se da inflação, hora-extra, rotatividade nos postos de trabalho. Essas armas agravam a situação do trabalhador. Ao operário consciente cabe atuar pensando no futuro. Concretamente, isso significa organizar grupos de fábrica, visando a construção de oposições sindicais. Coordenações operárias servem para organizar quem tem algum tipo de atuação. Essas formas de atuação não substituem o 115 Nova Luta, Nº9, março de 1974. 
sindicato, mas são maneiras propícias às tarefas do momento. Essa orientação para o trabalho operário é central para a Fração Bolchevique e depois para o MEP. A plataforma de reivindicações se concentra na defesa do salário, das condições de trabalho e na exigência de liberdade sindical.

O movimento estudantil volta à cena no contexto de suas reivindicações. O NL apresenta que a proletarização da classe média criou a necessidade de se buscar caminhos para manter sua posição de classe, como o ensino superior. Esse assunto já foi apresentado em número anterior no jornal. Mas vale ser ressaltado por se tratar de um tema importante - o movimento estudantil - no qual a organização teve atuação durante toda a sua jornada. Os ataques da ditadura colocaram o movimento dos estudantes na vanguarda, com destaque para 1968. Ocorre que as revindicações estudantis têm vínculo com sua origem de classe. Para superar os desvios, cabe a associação de dois elementos externos ao movimento. São eles a ideologia revolucionária e o movimento operário. Cabe ao partido exportar a sua ideologia aos estudantes que dirigem o movimento. $O$ fato do movimento estudantil ter acesso à cultura e à formação qualificada confere destaque relevante. A classe média tem acesso aos meios de comunicação e à arte, ferramentas da luta política. Os ataques à universidade e sua própria estrutura de poder refletem a luta de classe. Contribuem para a aproximação dos estudantes ao marxismo. Para que o movimento estudantil esteja próximo do movimento operário deve priorizar a luta política em detrimento de reivindicações pontuais.

Em setembro de $1974^{116}$, a Fração apresenta uma questão que irá perdurar até 1978: a linha para eleições gerais. Entendiam que, nos marcos da ditadura, as eleições não passavam de verdadeiras fraudes. O regime possuía todos os recursos para manipular os seus resultados: dinheiro, poder de coação, corrupção e a própria máquina repressiva. Nesse sentido, a participação do $\mathrm{MDB}$, na prática, jogava água em um moinho de vento. A oposição legal acabava por legitimar o regime na medida da sua própria existência. Ainda assim, essa oposição pouco podia fazer. Quando

116 Nova Luta, № 11, setembro de 1974. 
ousava aumentar o tom de voz, a resposta era a cassação de mandato, tal como ocorreu com Márcio Moreira Alves ${ }^{117}$. Mesmo a ala "autêntica" do MDB era vista com ressalvas. A Fração reconhecia a boa intenção, embora afirmasse sair o tiro da oposição pela culatra. Ainda nessa edição do jornal, discutem, como sempre, as condições do arrocho e as lutas operárias.

Antes do Congresso que formalizará a transformação da Fração em MEP, sai o Nova Luta em dezembro de $1975^{118}$. O que embalou o Congresso fundacional foram, sobretudo, duas grandes lutas. Uma em terreno nacional; a segunda do outro lado do Atlântico. Por aqui, o movimento estudantil se levanta na USP em razão da morte do jornalista Vladimir Herzog, assassinado nos porões do Doi-Codi. Desde 1968, seria essa a maior mobilização dos estudantes. A catedral da Sé foi palco de missas que se transformaram em verdadeiras manifestações contrárias à ditadura. Já do outro lado do Atlântico, Agostinho Neto liderava a vitória do Movimento Popular de Libertação de Angola, mais um país que saiu das garras do colonialismo para alinhar-se ao bloco comunista no contexto de guerra fria.

\section{6 À beira de 1976}

Passado o trauma das quedas, paulatinamente a Fração se reergueu. Foi um trabalho árdua, feito em nível celular, em que a disposição para o crescimento esbarrava nos limites da segurança imposta pela própria organização. Ivan Valente, então no Rio Janeiro vindo de São Paulo e responsável por reerguer o grupo, comenta que nos anos 73, 74 e 75, a construção política se dava através de redes muito pequenas de contatos. Aproximar um novo militante demandava um processo tão rigoroso que ocorria a passos lentos ${ }^{119}$. Jorge Paes, militante da Fração e estudante, à época, de letras na USP, comenta que naquela universidade havia uma célula da organização em 1973/4. Era composta por estudantes de letras, história e 117 Márcio Moreira Alves ousou criticar o Exército, chamando-o de valhacouto de torturadores. A não punição a Moreira Alves por parte dos parlamentares foi um dos pretextos para o Al-5.

118 Nova Luta, № 15, dezembro de 1974.

119 Entrevista concedida por Ivan Valente em 06 de abril de 2019. 
geologia. Já em 1975/6, as células estudantis se espalharam para mais cursos da USP, onde puderam se articular com outras células da Escola de Engenharia Mauá e da $\mathrm{FEI}^{120}$. De volta ao Rio de Janeiro, Vera Colson explica o crescimento que a Fração vivenciou sobretudo na UFF e na UFRJ ${ }^{121}$. O trabalho estudantil ganhava corpo, assim como a própria Fração. Não por outra razão, é comum nos relatos dos militantes a participação na Convenção Estudantil, que ocorreu no apartamento de Elisabeth Colson, irmã de Vera, em Botafogo. Por ceder o apartamento, Elisabeth teve que enfrentar as câmaras do DOI-CODI. Da Convenção Estudantil, saiu boa parte dos delegados que, na Convenção Nacional, formariam o MEP.

120 Entrevista concedida por Jorge Paes em 10 de abril de 2019.

121 Entrevista concedida por Vera Colson em 06 de abril de 2019. 


\section{SURGE O MEP}

O Movimento pela Emancipação do Proletariado foi o último capítulo da Política Operária. O seu surgimento se deu em janeiro de 1976, em Itaipava, no Rio de Janeiro, quando poucos militantes, jovens principalmente, chegaram com os olhos vendados ao local do encontro. Uma pequena chácara. Vinte e poucos delegados representavam poucas dezenas de militantes. A escolha da delegação foi feita a partir de encontros, ou Conferências, estaduais. Como na organização havia mais estudantes que operários, o peso do voto destes passou a valer mais, de modo a amenizar as distorções de representatividade ${ }^{122}$. Poucas dezenas que se transformaram em mil militantes em curto espaço de tempo ${ }^{123}$. Tanto assim que, após um ano e meio de sua fundação, a repressão operou um brutal ataque contra o MEP.

Já foi dito anteriormente, mas é fundamental deixar registrado, para evitar qualquer dúvida, que primeira e uma das principais marcas do MEP "é o de ser uma organização que assume a Revolução Socialista como a etapa atual da Revolução Brasileira"124. O caráter da etapa - sendo nacional e democrática, como defendiam o PCB e o PC do B, ou socialista, tal qual foi formulado de modo pioneiro pela POLOP, e assimilado também pela Fração Bolchevique, MR8, APML, é o marco divisor de maior revelo na esquerda entre meados dos anos 1960 e início de 1970. "Não por acaso estas organizações (FB/MEP,MR8, APMLe PO) configuravam a chamada Esquerda Proletária que - com base nesta identificação estratégica - alimentou esperanças de unificação no rumo da construção do partido comunista"125. A revista Brasil Socialista, editada no Brasil e também no exterior, foi um primeiro esforço de aproximação dessas organizações. Todavia, Luiz Arnaldo lembra que

122 Entrevista com Luiz Arnaldo, realizada em 11/01/2019.

123 Entrevista com Ivan Valente. Harnecker, Marta. O sonho era possível: a história do Partido dos Trabalhadores narrada por seus protagonistas. São Paulo. Casa América Livre/ MEPLA, 1994. Pg. 150.

124 Contribuição enviada por escrito por Luiz Arnaldo Campos Dias, em 05 de maio de 2019. 125 Idem. 
posteriormente as divergências entre estes agrupamentos inviabilizaram esta possibilidade. No final dos anos 80, PCB e PC do B foram aos poucos deixando de falar dos "restos feudais" da sociedade brasileira, abandonando a retórica etapista, embora jamais tenham feito uma autocrítica formal de suas postulações anteriores. Presas de suas contradições, a PO e a APML se dissolveram, o MR8 girou à direita até recuperar as formulações etapistas do PCB dos anos 60 , fazendo autocrítica do seu anterior "esquerdismo". O MEP manteve as concepções da Revolução Socialista e repassou este legado para o MCR ${ }^{126}$.

Ivan Valente sintetiza as principais ações do MEP em entrevista para Marta Harnecker. Lembrando a caminhada que remete à PO, diz que o MEP cresceu em paralelo ao processo de "distensão" de Geisel. Em 1977, a organização protagonizou importante manifestação anti-tortura na PUC-Rio, queimando uma cadeira do dragão. Isso em 1977, em plena ditadura. Já em 1978, no auge da luta pela liberdade de seus presos políticos, outra manifestação de massa foi organizada em frente à Auditoria da Aeronáutica, durante o julgamento desses presos, também no Rio da Janeiro. Em que pese a trajetória mais forte no seio do movimento estudantil, o MEP teve grande destaque no movimento de professores. Foi responsável pela organização das principais entidades estaduais e contribuiu para a nacional. O MEP possuía dirigentes em Minas Gerais, Pernambuco, Rio de Janeiro e São Paulo que atuaram com destaque. Ivan lembra do jornal O Companheiro e da postura do grupo de se dedicar à fundação do PT desde o início ${ }^{127}$. Esses tópicos e outros serão abordados mais adiante.

Já Antonio Ozai da Silva afirma que o MEP era uma organização marxistaleninista, contrária ao trotskismo e ao stalinismo, que visava construir um partido da classe operária como força de vanguarda da luta socialista. Compreendia que o capitalismo brasileiro era de tipo monopolista dependente, posto que seu desenvolvimento industrial se deu de modo subordinado ao capital estrangeiro. Em razão disso , o caráter da revolução seria socialista. O MEP estabelece que seu objetivo imediato era estreitar relações com a classe trabalhadora em torno de seus

126 Ibidem.

127 Entrevista com Ivan Valente. Harnecker, Marta. O sonho era possível: a história do Partido dos Trabalhadores narrada por seus protagonistas. São Paulo. Casa América Livre/ MEPLA, 1994. Pg. 151. 
objetivos concretos, por meio de propostas capazes de fazer avançar o movimento, assim como a consciência de classe ${ }^{128}$.

Outras fichas buscam sintetizar a história do Movimento pela Emancipação do Proletariado, como constam registradas no CPDOC da Fundação Getúlio Vargas ${ }^{129}$ e no próprio banco de dados do projeto Brasil: Nunca Mais ${ }^{130}$. Ainda assim, as informações que lá se encontram são mais gerais e já se encontram no corpo deste texto.

A Conferência Nacional que fundou o MEP foi também a primeira a ser realizada na trajetória da Fração Bolchevique, desde a separação da OCML-POLOP. A Conferência tinha o estatuto de Congresso, órgão máximo definidor. Como dito há pouco, as condições de se organizar um espaço denso de formulações eram muito adversas. Todavia, esse primeiro encontro nacional descreve a identidade do grupo de maneira mais pormenorizada. Busca delinear as questões programáticas. Avança nas teses sobre tática. Orienta a ação prática. Cria os critérios de militância. Ou seja, a Conferência sintetiza e ao mesmo tempo sofistica as principais formulações do MEP ${ }^{131}$.

Antes de entrar nas teses defendidas pela organização, vale começar a explicar o funcionamento do Movimento pela Emancipação do Proletariado a partir da sua estrutura. A Conferência Nacional é o órgão máximo de deliberação, devendo reunir-se a cada dois anos. A ela cabe eleger os membros do Comitê Nacional (CN),

128 Silva, Antonio Ozai da. História das tendências no Brasil: origens, cisões e propostas. São Paulo. DAG, 1986. Pg. 126.

129 Disponível em: http://www.fgv.br/cpdoc/acervo/dicionarios/verbete-tematico/movimento-pelaemancipacao-doproletariado-mep \%C3\%A7\%C3\%A3o+do+proletariado\&bib=bnm\&pesquisa=Pesquisar

131 As informações que se seguirão foram retiradas dos autos do Inquérito Policial Militar №7/77. Sua localização está em BNM_700 (50), (http://bnmdigital.mpf.mp.br/DocReader/DocReader.aspx?

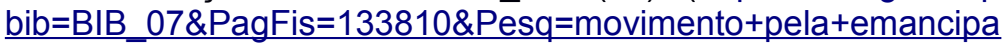
\% $3 \% \mathrm{~A} 7 \% \mathrm{C} 3 \% \mathrm{~A} 3 \mathrm{O}+$ do + proletariado). 
composto por três pessoas. Também no âmbito da Conferência, as resoluções de programa, tática e os estatutos da organização são aprovados. O Comitê Regional (CR) circunscreve-se a um estado. Seus membros são escolhidos em Conferência Estadual e confirmados pelo Comitê Nacional. Um membro deste comitê assiste ao Comitê Regional.

Cada Comitê Regional deveria se estruturar por setor, sendo eles o Setor Operário (SO), o Setor Estudantil (SE) e o Setor Interno (SI). O CR é dirigido por três militantes que assistem respectivamente a uma área de trabalho cada um, ou seja, um setor. Ao Setor Estudantil é subordinado o Comitê Estudantil, constituído por quatro militantes que dão assistência às bases universitárias.

Ao setor interno cabe administrar recursos, recolher e distribuir fundos, assegurar a produção e circulação dos documentos da organização, vigiar a segurança do grupo. Em poucas palavras, cuidam da logística de funcionamento político ${ }^{132}$.

Nos autos da investigação, consta que o Comitê Regional do Rio de Janeiro era assistido por "Gabriel", ou xxxx, como membro do Comitê Nacional. Outros membros que aparecem como participantes do CN eram Chico e Tony. O CR do Rio era composto por Ivan Valente, André Teixeira e Franklin Dias Coelho ${ }^{133}$. Os principais veículos de comunicação do grupo eram o jornal Nova Luta, que permaneceu mesmo após a Fração se tornar MEP, o jornal $1^{\circ}$ de Maio e a revista Teoria e Prática ${ }^{134}$.

Para identificar as formulações do MEP, vale a análise das resoluções da Conferência Nacional. No bojo chamado de estatutos, encontram-se resoluções sobre a militância, tática e programa.

132 Essas informações foram retiradas do próprio relatório de investigação da Aeronáutica e se encontram em BNM_700 (50). Pg. 453.

133 Idem. Pg 455.

134 Ibidem. Pg 456. 


\subsection{Resolução sobre programa}

Das principais novidades que aparecem como resultado da Conferência Nacional encontra-se a resolução sobre programa ${ }^{135}$. O documento busca localizar uma visão estratégica do MEP, partindo do Programa Socialista para o Brasil e críticas a este elaboradas. Começa por apontar a atualidade da revolução socialista, embora o contexto fosse de imensa dificuldade. Essa dificuldade reside em alguns fatores. Um deles tem a ver com a influência que setores revisionistas e reformistas conseguiram imprimir no movimento da classe trabalhadora nos últimos anos. llusões em possíveis alianças com setores da burguesia nacional e a crença na democracia burguesa desdobraram em uma cultura de movimento que minguava a independência da classe. Ao mesmo tempo, a ausência de uma política orientada pelo marxismoleninismo levou à desmobilização e à incapacidade de reação das massas diante de investidas golpistas, como o golpe de 1964 no Brasil e em 1973 no Chile.

No plano internacional, criticava-se a política pacifista de Brejnev, uma vez que esta ajuda a desarmar os partidos comunistas mundo afora. Por outro lado, também apresentavam ponderações à postura da China de atacar duramente a URSS, acusando um posicionamento aventureiro que mais enfraquecia do que fortalecia o movimento comunista internacional. O dado positivo guardava mora $\forall \underline{d a}$ no fato de que a luta de classes se acirrava mundialmente. Isso ajudava ao fortalecimento do lado revolucionário no interior dos países socialistas e dos partidos populares. Reafirmam a validade do marxismo-leninismo como norte da luta pela emancipação do proletariado.

Analisando o Programa Socialista para o Brasil, apontam os seus limites e os elementos que permanecem atuais. Vale dizer que o PSPB - ou PSB como às vezes se encontra grafado nos documentos - é a matriz da visão estratégica, o ponto de partida. Anunciam o PSPB como a maior expressão crítica ao reformismo, de modo que nisso reside o seu grande vigor.

135 A resolução sobre Programa encontra-se no item N¹05 do auto de apresentação e apreensão. BNM_700(50). Pg. 1662. 
Sem embargo, o documento apresenta limites. Ele foi formulado em um momento de derrota política e fraqueza da esquerda marxista. Sua divulgação data de 1967, ou seja, já no contexto de ditadura e dispersão dos movimentos contestatórios. Tais limites aparecem no texto através da influência da visão pequenoburguesa. Como o movimento dos trabalhadores estava desarticulado, os militantes da Fração não encontravam lastro de classe sobre o qual poderiam repousar suas teses. Uma das consequências disso é a incapacidade de orientar uma prática política alicerçada na classe trabalhadora. Nessa mesma direção, o PSPB não conseguiu ultrapassar os limites do doutrinarismo, restringindo-se à luta ideológica e à atividade intelectual.

Outro aspecto frágil do documento se encontra na caracterização que o PSPB faz das classes dominantes. Apresenta-as como um bloco homogêneo, sem frações ou divisões internas. Toma a crise de 1964 como uma crise permanente, algo que revelaria o bloqueio definitivo do desenvolvimento capitalista no Brasil.

A resolução do MEP questiona tal interpretação. Ora, se não há mais cisões ou divisões internas no interior das classes dominantes, então não há mais o que analisar no plano político. Logo, a luta de classes se transformaria em movimentações distorcidas: se restringiria à luta ideológica contra o reformismo e à formação artificial de um partido de vanguarda. De modo que o passo seguinte, de acordo com o PSPB, seria o desenvolvimento do foco guerrilheiro e a transformação do partido de vanguarda em partido de massas, dirigido por uma vanguarda. Primeiro, viria a luta ideológica. Segundo, a política.

Desse modo, o MEP apresenta as linhas de crítica ao PSPB. Mais à frente, veremos quais seriam as mudanças necessárias para o afinamento da linha política. Cabe ressaltar, aqui, os elementos de permanência do PSPB. Em primeiro lugar, ressaltam o caráter socialista da revolução, pedra angular do pensamento estratégico. O proletariado industrial continua sendo o principal ator do processo de mudança. O governo revolucionário dos trabalhadores da cidade e do campo se configura como a forma de governo provisório mais adequada na luta contra o poder 
político da burguesia. A luta pela liberdade de organização e manifestação caminha ao lado da construção do governo provisório. Enfim, essa síntese ajuda a combater os desvios pequeno-burgueses, tais quais o reformismo, o populismo e o liberalismo.

O MEP destaca que para cada etapa da revolução há uma estratégia, que consiste na desarticulação de algo para que o "novo" possa surgir. A estratégia é entendida como o desafio colocado para o momento, cuja superação permite destravar o caminho revolucionário. Na prática, o "novo" significava derrubar a ditadura e substituí-la pelo governo dos trabalhadores, garantidor da total liberdade de organização. O programa político é como um plano apropriado para viabilizar a estratégia. Ao partido político cabe a responsabilidade de dirigir a classe nesse processo.

A ideia, portanto, dessa reflexão sobre programa é partir do PSPB para articular uma superação dialética, uma manutenção/superação. Todavia, a Conferência Nacional reconhece que ainda não amadureceram formulação suficiente para dar conta do momento da superação. Logo, segue essa como uma tarefa pendente, ainda que com algumas balizas desenhadas.

\subsection{Sobre a militância}

Através dessa resolução, a Conferência apresentou a maneira como o MEP deveria funcionar, o papel e as responsabilidades de cada militante ${ }^{136}$. O primeiro ponto a ser destacado tem a ver com a primazia do partido, como o espaço indispensável para dirigir e fazer coadunar o conjunto das lutas. O MEP não é esse partido, embora ${ }_{\perp}$ enquanto um movimento pela emancipação do proletariado, the caiba agir pela sua construção.

Os critérios de organização do MEP seguiam a tradição leninista. O grupo guiava-se por alguns princípios organizativos e políticos. O centralismo democrático é um deles. Este princípio significa a busca pela unidade de ação do grupo. Uma vez 
estabelecidas as resoluções na Conferência Nacional, cabia a toda militância seguir com rigor. Compreendia-se a necessidade de uma direção forte, capaz de conduzir o grupo a partir das resoluções nacionais e à luz dos acontecimentos presentes. A disciplina partidária, desse modo, é imprescindível para a garantia da unidade de ação. Esta implica subordinação voluntária individual ao coletivo. Como não existe mudança conduzida individualmente, a ação em grupo passa a ser cláusula pétrea. $A$ disciplina nada mais é do que o encontro entre a liberdade e a solidariedade. $O$ indivíduo só pode ser livre se o Outro também o for. Logo, a liberdade só pode ser construída em coletivo. Essa liberdade é diferente da liberdade burguesa, na qual apenas poucos são de fato livres. Por seu turno, a solidariedade é fundamental para a ação coletiva. Identificando-se uns aos outros é que se pode atuar lado a lado. A solidariedade também é o que dá vazão política à empatia. Dessa maneira se entende a disciplina, ou seja, uma orientação que permite a realização da liberdade e da solidariedade, aspectos fundamentais da ação coletiva socialista.

Em contrapartida a essa disciplina militante, a organização deveria agir com justeza. Buscar uma linha política acertada, ter disposição de ouvir todas as vozes, aceitar críticas. Aliás, o direito à crítica é o pilar da democracia interna. Em momento de pré-conferência, tendências de opinião poderiam ser construídas e apresentadas ao conjunto da organização. Sem embargo, uma vez decida a linha, todos deveriam segui-la. Dava-se muito peso à questão organizativa, entendendo essa como elemento de uma unidade indissolúvel paralelamente à questão política.

Em uma organização leninista, ao lado do centralismo democrático, encontram-se os direitos e deveres de cada militante. Existiam condições para entrar no MEP, sendo elas concordar com o programa e estatutos, desenvolver prática revolucionária guiada pela tática e integrar algum organismo, a célula ou o comitê. Como a superação do PSPB estava em curso, diferenças de nuances poderiam ser aceitas. Divergência tática somente em época de debate interno. O sujeito postulante a entrar no MEP passava por um período de candidatura, no qual experimentava a vida militante para realmente saber se estava apto. Cabia à direção conformar a militância. 
A militância política deveria estar a serviço do movimento e da construção partidária. Esta implicava no fortalecimento do MEP e, por conseguinte, no processo de construção do partido da classe. A ação do militante atua no sentido do avanço da consciência da classe trabalhadora. Na verdade, ao MEP cabia essa grande tarefa. Exatamente por isso, dois riscos deveriam ser evitados a todo custo. $\mathrm{O}$ risco do isolamento, que faz com que a intervenção política não ajude a elevar a consciência. E o perigo da atuação enquanto seita: dedicada a si mesma e alheia ao mundo. Não cabia simplesmente ao militante ir de encontro ao movimento para garantir algum tipo de influência. O dever de aprender junto ao movimento se fazia fundamental. Somente na troca dialética é que se pode elaborar uma linha de atuação eficaz.

O MEP entende o militante comunista como uma pessoa diferente. Sua atuação no presente está atrelada ao amanhã. Por isso, a dedicação, o esforço, o abandono de convicções pequeno-burguesas devem ser guias. A apatia, o desânimo, a despreocupação com a ação coletiva eram outros desvios que precisavam ser combatidos. Tais sentimentos eram extremamente prejudiciais ao conjunto da organização e também para o movimento. Os militantes do MEP deveriam agir com profissionalismo da prática partidária. Não criticar a organização para fora. Saber que a crítica e a autocrítica deveriam sempre ter um conteúdo construtivo, deixando de lado questões menores ou de caráter individual.

O aspecto da segurança, como não poderia ser diferente em razão do clima repressivo, é matéria de bastante reflexão. A vida da organização não poderia ser afetada com os ataques da máquina repressiva do Estado. A política de segurança, assim, é intrínseca à luta revolucionária. O militante deveria seguir normas estritas de cuidados, assim como se comprometer com um comportamento revolucionário em caso de prisão.

A preocupação com a segurança advém da leitura de que o acirramento da luta de classes fez com que a burguesia se especializasse em combater quem se dispusesse a enfrentar o regime de opressão. Ainda que variasse em grau de intensidade a depender da conjuntura, os cuidados com a segurança eram inerentes 
à prática política. Alguns erros acabavam por ajudar a repressão, como o militarismo, o voluntarismo e desvios pequeno-burgueses.

Logo, se fazia necessário fechar as estruturas da organização aos ataques repressivos. Diga-se, a repressão tinha um tratamento prioritário. Havia um conjunto de regras que orientavam os cuidados. Estanquização orgânica. Havia um sistema estanque de repasse de orientações. As informações deveriam seguir um fluxo seguro, circunscrito à célula e ao assistente direto, de modo que somente o assistente sabia da atuação dos membros de uma dada célula, enquanto um representante do Comitê Regional sabia das práticas desse assistente, de acordo com a hierarquia do grupo. Especialização das células. Cada célula sabia tão somente da sua prática, desconsiderando inclusive a existência de outras células. Preservação da direção. Esta deveria ser preservada para garantir a linha de comando do MEP. Para tanto, deveria ser combatido qualquer liberalismo, entendido este como imprudência.

A prisão, no entanto, é vista como uma consequência quase natural da luta clandestina. O cárcere era um campo da luta de classes. E como tal o militante deveria enfrentá-lo. Não podia entregar nenhuma informação comprometedora, nenhum outro militante, nenhum fio de novelo que, se puxado, poderia fazer cair a organização. O revolucionário pensa no futuro. Se ele for derrotado na prisão, ameaça o futuro da luta. O MEP dizia que o militante deveria ter em mente que a força do movimento revolucionário é maior que a repressão. Pois essa força é moral. A luta revolucionária é em nome da justiça e dos mais pobres. O militante preso contava com a solidariedade das massas, por mais que essas não a expressassem no momento, pois, no futuro, certamente expressariam. O dever do militante era o de não trair o socialismo.

Ao preso caberia construir um álibi que permitisse não entregar nada que fosse relevante e pudesse aliviar as condições de sua prisão. A orientação era negar qualquer prática considerada subversiva. Em segundo lugar, sempre se colocar na posição menos destacada possível. Essas regras poderiam ajudar no alívio das 
penas. Para além disso, o militante deveria aguentar o peso da sevícia. Para quem vacilasse na prisão, outro julgamento ocorreria. Dessa vez, no interior do próprio MEP. O militante que cometeu erro político na cadeia deveria apresentar sua defesa a uma banca de dirigentes. Esta avaliaria a sentença, podendo ser um processo de reeducação política à expulsão sumária.

Ainda sobre os deveres do militante, havia o aspecto da contribuição material. Este servia, sobretudo, para manter a organização. A contribuição individual era o principal meio para obtenção de recursos, ainda que fossem estimuladas outras opções, quando o contexto permitisse. Os recursos serviam para garantir a atividade de quem estava na clandestinidade, produzir materiais, bancar situações de emergência, como serviços advocatícios e médicos. O movimento estudantil, por sua origem de classe, tinha papel destacado na função de arrecadação. $O$ debate material estava no âmbito político e de compromisso com a construção do MEP.

Por fim, todo integrante da organização deveria investir constantemente na elevação de seu nível de consciência. Destaca-se o estudo do marxismo-leninismo, ferramenta para interpretar o mundo e agir sobre ele. Há a preocupação de se questionar os dogmas. $\mathrm{O}$ marxismo não era visto como um ferramental pronto, mas algo em movimento, vivo. A formação militante era essencial para desenvolver as capacidades de agir, convencer e liderar. Também fundamental para enriquecer as formulações da organização. O patamar mínimo de formação envolvia os seguintes textos: PSPB e a Resolução sobre Programa; Teses sobre a Tática; Estatutos, Documento de Militância; Resoluções sobre Política de Organização. Quanto ao plano de formação teórica mínima, estavam o Curso Básico (este formulado pela PO); o Manifesto do Partido Comunista; Que Fazer?; O Estado e a Revolução; e a revista Teoria e Prática. Um último destaque, a prioridade deveria ser dada para as questões de estratégia e programa. Essas regras desenham a dinâmica interna da organização clandestina. 


\subsection{Teses sobre a tática}

Nesse tópico, o MEP avançou em uma leitura da realidade que combina análise da conjuntura em paralelo às questões estruturais ${ }^{137}$. Resgata, logo no início, que ele próprio faz parte de um movimento nascido para superar o reformismo, visto, principalmente, no PCB e no PCdoB. Entretanto, este movimento se formou desligado da classe operária e que, portanto, superou o reformismo apenas no plano intelectual. Caberia, logo, superá-lo na prática.

Antes dos tópicos em que se analisa a conjuntura e propõe uma linha política, assim como em vários outros momentos, o MEP reafirma a compreensão de que o capitalismo brasileiro é de tipo monopolista. Interessante notar que alguns elementos novos de aspecto interpretativo aparecem nesse tópico de caracterização do capitalismo. Além de monopolista, o capitalismo no Brasil é violentamente predatório. A configuração atual do capitalismo resulta de uma nova ordem política e social, formada a partir da fusão entre industrialização e o sistema agrário-exportador, sob a égide do populismo e da hegemonia da burguesia industrial. A tônica é a superexploração, através da qual se formou essa nova ordem e sobre a qual se desenvolve.

O sistema produtivo, desenvolvido com o encontro entre relações modernas e atrasadas de produção, opera de modo dependente ao imperialismo. Parte da riqueza produzida é apropriada pelo centro capitalista, através do capital externo na indústria, pela subvalorização de exportações, pela supervalorização de importações e, enfim, pela presença do capital financeiro. Este saque consentido é custo do desenvolvimento do capitalismo no Brasil.

O populismo, ao mesmo tempo que foi fundamental para o estabelecimento da nova ordem política e social, não conseguia mais conter os impulsos da classe operária por maior participação na riqueza produzida. A reação buscou uma nova ordem, capaz de assegurar a estabilidade política e o regime de super-exploração. A ditadura militar encarnou essa responsabilidade, de maneira a preservar a hegemonia 
do grande capital industrial e financeiro. Aliás, as bases de sustentação política da ditadura se articulam entre os interesses da burguesia monopolista e da burocracia estatal, representada pelos militares. A construção da hegemonia se deu pela repressão às lutas dos trabalhadores. Mesmo método escolhido para a criação do chamado "milagre econômico".

O "milagre" ocorreu às custas do arrocho salarial e da repressão ao movimento dos trabalhadores. Uma de suas consequências foi o aumento das contradições do desenvolvimento capitalista no Brasil, de tal forma a aprofundar o caráter da dependência. Isso podia ser visto no aumento da concentração de capitais e renda, no avanço da super-exploração, na ampliação da integração com o imperialismo e com a conservação de um mercado interno de alta renda.

Todavia, com o estancamento do "milagre", a situação política começa a mudar de figura. O arrocho estrangulava a vida dos mais pobres. Mesmo setores da burguesia, de orientação mais liberal, começaram a criticar o regime, em especial quanto ao excesso de intervencionismo estatal. Esse quadro se revelou na eleição de 1974, quando o MDB saiu vencedor do pleito. Para estabilizar a situação, os militares buscaram institucionalizar a ditadura, ainda que a retórica de distensão surgisse aos poucos. Distensão era entendida como um desenvolvimento com segurança. $\mathrm{Na}$ prática, a repressão volta com arroubos por trás da fachada democrática.

Do outro lado, cresce a oposição liberal, com suas campanhas pela redemocratização. O MDB, na ausência de representatividade operária, canaliza as reivindicações democráticas e populares em um duto político/eleitoral. Vide as eleições de 1974. A luta pela redemocratização é de interesse de parte da burguesia e da pequena-burguesia, sendo esta representada pela ala autêntica do MDB.

O MEP é crítico audaz da política do MDB e de seus caminhos de resistência. Aponta, antes de mais nada, que a aposta nos canais abertos pela ditadura é perigosa, pois ajuda a construir a fachada democrática do regime e adentra em terreno repleto de armadilhas. Os compromissos dos adeptos da campanha pela redemocratização, para completar a crítica, dão conteúdo burguês às formas de luta e 
às perspectivas futuras. O MDB acaba por aceitar o processo gradual de reforma política, o que também consiste em outra armadilha.

Ao passo que cresce na sociedade os anseios pela redemocratização, avança também a luta operária. No campo das reivindicações econômicas se encontra o terreno fértil para desestabilizar politicamente a ditadura. Em que pese as melhores condições para a resistência operária, lembra o MEP, não estava desenhado o sucesso na mudança da correlação de forças. Nesse sentido, muita combatividade seria necessária. O movimento estudantil jogava papel muito relevante, uma vez que ao denunciar o regime contribuía para o seu desgaste.

Então, o que fazer para alterar a correlação de forças? Para o MEP, o segredo estava na capacidade de modificar as relações de trabalho. A ditadura degradou a vida dos trabalhadores e tornou a luta econômica algo subversivo. O xis da questão se revela na compreensão de que a correlação de forças se dá em cima das condições de trabalho: controle salarial, péssimas condições nas fábricas, ausência de estabilidade no emprego, manipulação nos índices de inflação, crescentes arbitrariedades. Essas condições aviltantes são asseguradas pelo controle repressivo. Tal quadro enfraquece as condições objetivas de sobrevivência da classe trabalhadora, logo a sua capacidade de resistência. Dito isso, para alterar a correlação, era necessário superar a condição de subordinação dos trabalhadores. Politizar a situação de penúria. Fazer com que a classe entendesse que a exploração fazia parte do projeto político da ditadura. Cabia, então, encontrar os caminhos que permitiriam enfrentar esse desafio.

Dentre as forças de oposição à ditadura, o MEP identifica quatro propostas diferentes de como operar a resistência. Existe a opção pelo movimento de redemocratização, liderado pelo $\mathrm{MDB}$, com o apoio dos reformistas, leia-se o PCB. $\mathrm{O}$ problema visto nessa opção - para além de seu conteúdo de classe e de fazer parte da fachada democrática - é que não havia a crítica contundente ao capital monopolista e ao regime da super-exploração. Restringindo-se a crítica política à ditadura, as reivindicações dos trabalhadores ficavam de fora. Mais grave, 
conjecturando uma hipótese de vitória dessa linha política, a classe trabalhadora continuaria vítima da super-exploração. Portanto, não teria como mobilizar as massas para alterar a correlação de forças através de uma proposta que não satisfazia as demandas populares. Não se tratava ainda de negar por princípio a legalidade ou a afirmação de compromissos, desde que essas ações ajudassem no desenvolvimento da consciência de classe.

Para outros, o caminho se dava através do fortalecimento da oposição pequeno-burguesa, representada pela ala autêntica do MDB. O problema que aqui reside está na impossibilidade desse setor derrotar a ditadura sem alianças com setores mais amplos da burguesia. Os autênticos jogavam dentro das regras, logo esbarravam em problemas semelhantes daqueles que optaram pelo caminho da simples redemocratização. Setores da esquerda proletária de algum modo se alinhavam à escolha dos autênticos, como a AP e o MR8.

Existiam aqueles que apostavam no impasse formado pela crise econômica, desejo de mudança de setores da burguesia e vacilações da ditadura. Nesse contexto, o movimento operário reacender-se-ia. Logo, a disputa estava no campo da luta ideológica contra o reformismo no interior da luta operária. Na prática, essa tática poderia ser resumida pela ausência de política. Quem a defendia era a OCML-PO.

Para o MEP, o fator decisivo para alterar a correlação de forças estava no crescimento das lutas de resistência econômica do proletariado. Agitando-se por melhores condições de vida e trabalho, a classe politizaria a sua condição de pobreza e exploração. Justamente a classe trabalhadora possuía a condição de questionar a ditadura através de reivindicações justas e apontar para um tipo de governo que não manteria as amarras da super-exploração, nem da dependência ao imperialismo. Também aos trabalhadores estava reservada a capacidade de desestabilizar o regime através das greves e outras formas de paralisar a produção. O enfrentamento no plano econômico desestabilizaria o arranjo político das forças de sustentação da ditadura. As condições para a sua queda, portanto, seriam mais favoráveis. 
Reconhecia-se que o movimento dos trabalhadores não possuía força suficiente para enfrentar a ditadura. A tarefa, então, estava em centrar esforços para estimular as lutas operárias, de modo a criar um círculo virtuoso. Ao mesmo tempo em que se deveria participar de toda e qualquer luta econômica, um conjunto de palavras de ordem deveriam acompanhar: livre organização e manifestação política dos trabalhadores; liberdade sindical e autonomia dos sindicatos; direito de greve; organizar e eleger comissões de fábrica; fim da máquina repressiva; fim das torturas e liberdade aos presos políticos; fim do arrocho; congelamento dos preços, elevação geral dos salários e garantia de emprego para todos.

A tarefa principal do MEP passava a ser, então, a atuação no movimento operário. Como a organização era pequena, cabia investir, por óbvio, nos desafios que estavam ao alcance. Nos locais em que tinham atuação ou algum contato, cabia questionar os sindicatos pelegos, sem abrir mão de reivindicar o sindicato em si. As oposições precisavam ser fortalecidas, ao lado de ações diretas junto à classe. Cabia disputar a camada mais avançada dos trabalhadores, os mais politizados e mais destacados nas pequenas lutas. Em parceria com outras forças e operários mais avançados, o desafio constituía em construir frentes de unidade, e disputar a linha política no interior dessas. O MEP deveria aproveitar a tendência de crescimento da agitação entre os trabalhadores para fortalecer sua atuação sindical.

O trabalho popular em bairros ganha uma dimensão especial. Aparecia como uma frente secundária, mas capaz de auxiliar a prática sindical combativa, sobretudo em bairros operários. O contato com as famílias e amigos ajudava a criar boas condições de politização, tendo em vista a carestia que se espalhava. Os círculos operários também eram instrumentais capazes de reunir trabalhadores do mesmo local de trabalho e mesmo de outros lugares.

A resolução sobre a tática aponta os desafios para o movimento estudantil. Critica o sistema educacional burguês, voltado para a manutenção do regime de exploração, enquanto os estudantes eram formados para serem tecnocratas desse mesmo regime. Essas imposições geravam mal-estar entre os estudantes, que 
muitas vezes se rebelavam contra essas estruturas. A principal tarefa do movimento estudantil consistia em quebrar as barreiras que impediam a luta contra o sistema educacional e se manifestar frente aos fatos políticos, contribuindo assim pelo enfraquecimento da ditadura. O MEP deveria atuar no sentido do fortalecimento das suas organizações e das lutas de resistência. Como o movimento dos estudantes era naturalmente pequeno-burguês, cabia implantar uma política proletária, aliando a luta estudantil aos desafios da classe. Em síntese, construir uma vanguarda socialista entre os estudantes.

Essas teses compunham a interpretação geral do MEP sobre o país e as demandas que cabiam à organização. A perspectiva de fortalecimento do grupo era acompanhada pela orientação de unir a esquerda revolucionária. Os passos seguintes desenham melhor como essas perspectivas se materializaram. 


\section{A QUEDA (1977-1978)}

O Estado brasileiro montou uma arquitetura da repressão, durante a ditadura militar, para aniquilar as oposições. Para tanto, foram mobilizados vários artifícios para viabilizar o controle sobre grupos sociais. Foi criado um conjunto de leis que buscava dar uma fachada legal às ações arbitrárias, como cassações e mandados de prisões. O poder judiciário foi articulado de modo a garantir o sistema de abafamento social. Além, claro, de toda a estrutura repressiva, composta pelas inteligências das Forças Armadas em parceria com as polícias. Essa arquitetura possuía modus operandi flagrantemente criminoso, pois funcionava com base em mentira, coação, prisões ilegais, censura, tortura, assassinato e ocultação de corpos. Estruturalmente, o Estado brasileiro é culpado por esses crimes, não somente os operadores das barbáries, mas, sobretudo, a alta hierarquia de comando, ou seja, o Estado-Maior Conjunto das Forças Armadas ${ }^{138}$.

Com o golpe militar de 1964 , os militares passaram a por em prática a chamada Doutrina de Segurança Nacional, elabora em meados de 1950 no âmbito da Escola Superior de Guerra (ESG). Esta instituição se formou após a Segunda Guerra Mundial, a partir da experiência da Força Expedicionária Brasileira (FEB), a qual combateu em campos da Itália, subordinada ao comando norte-americano. Dos oficiais que se destacam nesse contexto estão o marechal Humberto de Alencar Castello Branco e o general Golbery do Couto e Silva. O contato estabelecido entre as Forças Armadas brasileiras e as norte-americanas foi derradeiro no sentido de alinhavar a orientação das Forças nacionais. O próprio Golbery explica: "A FEB não foi importante só pela ida à Itália. Possivelmente, ainda mais importante tenha sido a

138 Em abril de 2010, o STF rejeitou a Arguição de Descumprimento de Preceito Fundamental (ADPF 153), perpetrada pela OAB Nacional, que pedia a revisão na Lei de Anistia (6683/79). Argumentavase que os militares construíram uma autoanistia, além de que os crimes contra a humanidade cometidos pelo Estado brasileiro são imprescritíveis. A ação foi derrotada por 7 votos a 2. À época, o presidente da Corte, Cézar Peluso, argumentou que "só o homem perdoa, só uma sociedade superior qualificada pela consciência dos mais elevados sentimentos de humanidade é capaz de perdoar. Porque só uma sociedade que, por ter grandeza, é maior do que os seus inimigos é capaz de sobreviver". Ver: http://www.stf.jus.br/portal/cms/verNoticiaDetalhe.asp?idConteudo=125515 
visita da FEB aos EUA. [...] Eu fui, e foi um grande impacto"139.

Ao voltarem, os militares brasileiros possuíam outra noção do que significa a defesa nacional e o "Poder Nacional". O inimigo não era mais externo. Era interno e com poder de desestabilizar as instituições. Às Forças caberia controlar esse inimigo presente na própria população brasileira ${ }^{140}$. Exército, Marinha e Aeronáutica passariam a enfrentar o seu próprio povo.

A Doutrina de Segurança Nacional passa a orientar-se por esta compreensão. Formulada na Escola Superior de Guerra, os militarem colocam a Doutrina em prática de maneira mais sofisticada com a criação do que ficou conhecido como Sistema Nacional de Informações, em junho de 1964. Seu mentor intelectual, Golbery do Couto e Silva. A chave para o sucesso do país estava na Segurança Nacional. Em plena Guerra Fria, a ameaça interna vinha da parte dos movimentos que reivindicavam melhores condições de vida e maior participação na riqueza nacional, pois eles, supostamente, aliavam-se ao comunismo internacional e punham em xeque as instituições.

Com isso, os militares investiram na preparação da guerra interna. O Sistema de Segurança Nacional era composto pelo Conselho de Segurança Nacional (CSN), principal centro de decisão da ditadura, até os porões de tortura, passando pela Lei de Segurança Nacional, atos institucionais, censura à imprensa e por aí adiante. $\mathrm{O}$ SNI possuía uma sede em Brasília e oito subsedes espalhadas pelo território nacional. Com o avanço da repressão e das medidas de controle social, passaram a buscar estruturas que unificassem as Forças, a Polícia Federal e as polícias estaduais $^{141}$. A experiência piloto dessa integração se deu com a Operação Bandeirantes (Oban), oficiosa, em meados de 1969, a qual integrava Exército, Marinha, Aeronáutica, Polícia Política Estadual, Departamento de Polícia Federal,

139 Essa afirmação encontra-se em Brasil: Nunca Mais. Editora Vozes. São Paulo, 1985. Pg. 78. No original, a citação está em A repressão militar-policial no Brasil, 1975, p. 22 [mimeo].

140 Brasil: Nunca Mais. Editora Vozes. São Paulo, 1985. Pg. 78

141 Brasil: Nunca Mais. Editora Vozes. São Paulo, 1985. Pg. 80. 
Polícia Civil, Força Pública e Guarda Civil ${ }^{142}$. Todo esse operativo se organizava nos fundos de uma delegacia da rua Tutóia, em São Paulo. O sucesso desse operativo levou à criação, dessa vez oficial, do DOI-CODI (Destacamento de Operações de Informações - Centro de Operações de Defesa Interna), em janeiro de 1970. A experiência nacionalizou-se. O DOPS (Departamento de Ordem Política e Social) existia desde o Estado Novo e continuou sendo utilizado pela ditadura militar.

Todo um arcabouço jurídico foi criado para legitimar e assegurar a repressão. Em abril de 1964, foram criadas as Comissões Gerais de Investigação (CGD), responsáveis por centralizar os inquéritos policiais e inquéritos policiais militares (IPMs). No início do regime militar, o STF ainda conseguia frear arbitrariedades, interrompendo IPMs através da concessão de habeas corpus. No entanto, após a edição do Ato Institucional N²2, em 27 de outubro de 1965, os crimes relacionados à segurança nacional passaram para a esfera da Justiça Militar. Este mesmo ato aumentou a composição do STF de 11 para 16 membros, de modo a acolher ministros alinhados ao golpe. Nesse momento, a jurisdição passa ser o arbítrio e sequer as leis da ditadura eram respeitadas pelos órgãos de repressão, autores de práticas que continham a anuência da Justiça Militar.

A Justiça Militar ocorria nas Circunscrições Judiciárias Militares (CJMs), que correspondiam às bases territoriais das Forças (Região Militar, Distrito Naval e Comando Aéreo Regional) ${ }^{143}$. Para cada base territorial, havia uma (ou mais) auditoria militar, similar ao fórum da justiça civil. Logo, para o Comando da $1^{\text {a }}$ Região Militar do Rio de Janeiro, estava a $1^{\text {a }}$ Auditoria do Exército da $1^{\text {a }}$ CJM. Para o Comando da Aeronáutica também do Rio de Janeiro, havia a $1^{\text {a }}$ Auditoria da Aeronáutica da $1^{\text {a }}$ CJM. Nos bancos deste tribunal, os militantes do MEP foram parar.

A $2^{\mathrm{a}}$ Instância da Justiça Militar era o Superior Tribunal Militar (STM), ao qual cabia recursar decisões das Auditorias. O STM era composto por 15 ministros vitalícios, indicados pelo presidente da República e referendados pelo Senado 
Federal. A composição se dava por três oficiais generais da ativa da Marinha de Guerra, três oficiais generais da ativa da Aeronáutica, quatro oficiais generais da ativa do Exército e cinco juízes civis. A última instância da Justiça brasileira era o Supremo Tribunal Federal.

A Junta Militar que governou o país no interregno entre Costa e Silva e Médici criou, em outubro 1969, um "pacote legislativo", consumado no Código Penal Militar (CPM), Código Processual Penal Militar (CPPM) e com a Lei de Organização Judiciária Militar (LOJM). Estava desenhado o quadro do arbítrio jurídico. A Justiça Militar, assim, atuava como elemento legitimador da máquina repressiva.

O inquérito policial começava no DOI-CODI ou em alguma agência de inteligência militar. Em um segundo momento, vinha a fase do "cartório", na qual o preso direcionava-se para o DOPS ou para a Polícia Federal. A segunda etapa buscava "legalizar" toda sorte de abusos cometida na primeira. O inquérito, então, era enviado à Auditoria que, por sua vez, repassava ao promotor militar responsável por oferecer a denúncia. O denunciado deveria ser submetido a julgamento do Conselho de Justiça, composto por quatro oficiais e por um juiz civil, presidido pelo militar de mais alta patente ${ }^{144}$.

A prisão preventiva, as provas, a busca pela confissão, a prova pericial, a prova testemunhal, as apreensões e a prova documental eram sistematicamente forjadas a partir dos interesses do órgão investigador. Tanto o acusado quanto o Ministério Público possuíam o direito a recorrer ao STM, embora fossem raras as vezes em que houvesse grande alteração nas decisões do Conselho de Justiça.

Desde o início, a ditadura mostrou a que veio. Em 9 de abril de 1964, foi instaurado o Ato Institucional N¹. Deveria ser o único, mas não foi. Castello Branco afirmou, imponente, que a Revolução legitimava a si mesma como Poder Constituinte $^{145}$. Em 11 de junho, prazo em que deveriam cessar as cassações, o saldo foi três ex-presidentes cassados (Juscelino, Jânio e Jango), seis

\footnotetext{
144 Ibidem. Pg. 209.

145 Ibidem. Pg. 65.
} 
governadores, dois senadores, 63 deputados federais e centenas de deputados estaduais e vereadores. Entre os militares, foram reformados 77 oficiais do Exército, 31 da Aeronáutica e 14 da Marinha. Cerca de dez mil funcionários públicos foram demitidos. Cinco mil inquéritos passaram a investigar 40 mil pessoas. Para centralizar as investigações, foi criado a Comissão Geral de Investigação (CGI ${ }^{146}$. Visando limitar o espaço de atuação das oposições, em outubro de 1965, foi editado o Ato Institucional №2, que impôs o bipartidarismo. O Ato Nㅜ3, de fevereiro de 1966, tornou as eleições para governador indiretas.

Ainda em 1966, o "colégio eleitoral militar" escolhe Costa e Silva como presidente. Com sua posse em março de 1967, surge uma nova Constituição, com uma nova Lei de Segurança Nacional. O cerco de fecha, e a ditadura se torna escancarada, no dia 13 de dezembro de 1968, com a edição do $\mathrm{Al}-\mathrm{N}^{0} 5^{147}$. O Congresso é fechado, mais 63 deputados são cassados. Carlos Lacerda, apoiador do golpe militar enquanto governador da Guanabara, acabou cassado por aqueles que ajudara a assumir o poder. Adhemar de Barros e Magalhães Pinto já o tinham sido. A ditadura tornara-se contra tudo e todos que pudessem atrapalhar seu domínio. Os direitos individuais foram liquidados.

O habeas corpus foi suspenso. Instaura-se a incomunicabilidade dos presos. O terror de Estado está, enfim, desenhado na lei. Emílio Garrastazu Médici assume em 30 de outubro de 1969, defendendo "segurança e desenvolvimento".

A máquina de moer opositores dispara. A temperatura política aguça-se com a luta armada. Do ponto de vista econômico, o "milagre" aquieta as classes dominantes e setores da classe média. Todavia, após o choque do petróleo em $1973^{148}$, ao lado do desajuste econômico, aumentam os gritos da oposição. No

146 Ibidem. Pg. 65.

147 Ver Napolitano, Marcos. 1964, História do Regime Militar. Editora Contexto Capítulo: "Democracia Relativa": os anos Geisel. São Paulo, 2014; Gaspari, Elio. A ditadura derrotada. Editora Intrínseca. São Paulo, 2014; Reis, Daniel Aarão. A vida política. In: Modernização, ditadura e democracia (19642010). Org. Daniel Aarão Reis. Editoras Funación Mapfre e Objetiva. São Paulo, 2014.

148 Ver Singer, Paul. O processo econômico. In: Modernização, ditadura e democracia (1964-2010). Org. Daniel Aarão Reis. Editoras Funación Mapfre e Objetiva. São Paulo, 2014. 
segundo semestre deste ano, Geisel é escolhido para a presidência. Dessa vez, o plano dos militares é distensionar para recuperar legitimidade. Não sem encontrar resistência da chamada linha dura do Exército, comandada pelo Ministro do Exército, Sylvio Frota. O projeto Brasil: Nunca Mais assim explica este momento: "os órgãos de segurança pareciam ter estabelecido como meta uma "última varrida" em todos os agrupamentos de esquerda, para aniquilar tudo que tenha resistido à repressão anterior"149. Essa última empreitada, resultante de toda engenharia da repressão acima descrita, atingiu em cheio o Movimento Pela Emancipação do Proletariado.

\subsection{A repressão atinge o MEP}

As prisões do MEP tiveram imensa repercussão no debate público nacional. Isso porque tais prisões se constituíram como um ponto fora da curva na conjuntura pautada pela promessa de "distensão". Dos principais defensores dos presos políticos, o advogado Heleno Cláudio Fragoso comenta que o caso do MEP foi o último, no Rio de Janeiro, em que teve o funcionamento do DOI-CODI com emprego da tortura como método de obtenção de depoimentos, fato que revelou que a máquina de massacrar opositores continuava em funcionamento ${ }^{150}$. No fim dos anos 1970, não havia mais grupos ligados à luta armada. O DOI-CODI buscou um adversário que, no momento, não representava riscos à ordem política e social, o que atesta certa autonomia e descontrole do órgão de repressão.

De acordo com Fragoso, o MEP era uma organização de estudantes que "em qualquer país democrático teria existência legal. Nada no seu programa indicava o propósito de recorrer à luta armada como forma de atuação política"151. Os presos caíram, para usar expressão comum entre aqueles que atuavam na clandestinidade,

149_lbidem. Pg. 70.

150 Fragoso, Cláudio Heleno. Advocacia da liberdade. Editora Forense. Rio de Janeiro, 1985. Pg. 164.

151 Idem. Pg. 164. 
no fim do mês de julho de 1977. A prática do sequestro, seguida de encapuzamento, foi utilizada para levar os jovens à temerária rua Barão de Mesquita, onde, nos fundos do I Batalhão da Polícia do Exército, se localizava o DOI-CODI. As torturas foram imediatas. Espancamentos, geladeira, terror psicológico, choques elétricos. Os dez dias de incomunicabilidade permitiam que o horror funcionasse sem obstáculos.

Vale registrar que esta não foi a primeira vez que militantes do MEP foram presos pelo regime militar. Em São Paulo, entre os dias 10 e 14 de julho ${ }^{152}$, alguns estudantes ligados à organização e outros-; identificados com a Liga Operária- foram detidos por panfletarem em fábricas do ABC Paulista. Todavia, as implicações tiveram proporção menos drásticas.

Os acusados que responderam processo foram Elza Maria Pereira, Lianza, Maria Cecília Barbosa Wetten, Maria de Fátima Martins Pereira, Ignácio Guaracy de Souza Lemos, Arthur Obino Neto, Franklin Dias Coelho, André Teixeira Moreira, Cláudio de Rocha Roquete, Ivan Valente, Luiz Arnaldo Dias Campos, José Augusto Dias Pires e Sidney Lianza. Por fim, Errol Dias Peçanha, Frederico José Falcão, Fernanda Duclos Carísio, José Mendes Ribeiro e Jorge José de Melo ${ }^{153}$.

A polícia atuava para criar uma narrativa desfavorável aos militantes junto à opinião pública. Ainda no fim de julho, apresentaram à imprensa material "subversivo" recolhido em sete "aparelhos" ${ }^{54}$.

No dia 22 de julho, o DPPS (Departamento de Polícia Política e Social, continuidade do DOPS) comunica a prisão de outros acusados de subversão. Nessa lista, encontravam-se nomes que posteriormente não receberam denúncia do Ministério Público Militar, como Henrique Santos Neder, Ricardo Soares Pamíaco, Marlita Camargo, Roberto Wanderlei Valente e Alice Isabel ${ }^{155}$. No dia 27, novas 152 O Globo, 14 de julho de 1977.

153 Folha de São Paulo, 11 de outubro de 1977. Estes últimos respondiam em liberdade quando o Ministério Público Federal apresentou as denúncias.

154 O Globo, 30 de julho de 1977.

155 Eles tiveram a prisão relaxada, entre 11 e 13 de agosto, a mando do juiz Mário Moreira de Souza, 
prisões $^{156}$. Aqueles que foram detidos por volta do dia 20 receberam, passado o período de incomunicabilidade, visitas de advogados e familiares no dia $29^{157}$.

A luta política de denúncia das arbitrariedades logo começou. No dia 26 , os estudantes organizados no COPPE (Instituto Luiz Alberto Coimbra de PósGraduação e Pesquisa em Engenharia da UFRJ) paralisaram suas atividades em protesto contra as prisões ${ }^{158}$.

No dia 03 de agosto, após sair do DPPS, quando se situou do que estava ocorrendo, Heleno Fragoso convocou uma coletiva de imprensa para narrar os horrores a que teve acesso. Os jornais do dia 04 publicaram as denúncias ${ }^{159}$. 0 advogado encaminhou petição ao auditor da $1^{\text {a }}$ Auditoria da Aeronáutica, exigindo que a Justiça cobrasse explicações ao comandante do I Exército. No final da petição, dizia Heleno:

"A tortura de presos políticos volta a surgir como rotina da investigação criminal, e as prisões continuam a ser feitas sob a forma de sequestro, sem ordem escrita da autoridade competente. Protegem-se os torturadores submetendo os presos ao martírio do uso permanente de um capuz, para que não possam ser investigados, porque têm consciência de que estão praticando crime. A gravidade do fato, que atinge de forma brutal a dignidade da pessoa humana, resulta da circunstância de ser a tortura institucionalizada e organizada por órgão oficial. Não se confunde com a violência da polícia, ocasional ou episódica. Trata-se aqui de uma organização do Estado, que se sobrepõe às leis, e que faz da tortura o seu método rotineiro de investigação. Isso se torna possível pela inexistência do habeas corpus, o que significa verdadeira licença para o abuso e a violência bem como pelo longo prazo de incomunicabilidade que, ilegalmente, atinge, inclusive, os advogados"160.

por considerar não relevantes para as investigações. Ver O Globo, 13 de agosto de 1977.

156 Como as prisões eram ilegais e os presos ficavam em regime de incomunicabilidade, é difícil encontrar com precisão a data de entrada de cada um dos presos especificamente nas dependências do DOI-CODI. Sabe-se, no entanto, através dos relatos dos jornais e da defesa dos presos que as prisões começaram a ser efetuadas entre 18 de julho até o dia 30 deste mês.

157 Folha de São Paulo, 30 de julho de 1977.

158 O Globo, 27 de julho de 1977.

159 Jornal do Brasil, 27 de outubro de 1977. Esta edição do jornal apresenta a queda do MEP com imenso destaque. São mais de duas folhas inteiras dedicadas às prisões. Relatos de advogados, militantes, representantes da ditadura, o próprio processo jurídico é descrito em detalhes e até mesmo uma carta escrita pelos presos no interior do cárcere foi publicada. Sem dúvidas, essa edição contribuí como fonte de grande riqueza.

160 Fragoso, Cláudio Heleno. Advocacia da liberdade. Editora Forense. Rio de Janeiro, 1985. Pg.168. 
O inquérito construído com base nesses métodos foi entregue à la Auditoria da Aeronáutica no dia 16 de agosto, pelo delegado do DPPS, Borges Fortes ${ }^{161}$.

Alguns militantes do MEP, por terem resistido a assinar confissões, foram mandados de volta ao DOI-CODI, como foi o caso de Luiz Arnaldo Campos Dias. O advogado Lino Machado Filho enviou representação à I Auditoria contra a transferência do DPPS ao DOI-CODI, mesmo depois de ter passado o período de incomunicabilidade. Em protesto contra a volta da tortura física, 19 militantes fizeram greve de fome por seis dias, tendo esta terminado no dia 05 de agosto ${ }^{162}$.

O clima de tensão era tamanho que os próprios advogados de defesa, conforme as prisões preventivas foram sendo relaxadas temporariamente, pediam aos presos que não denunciassem as torturas, pois isso afetaria a defesa jurídica ${ }^{163}$, já que se tratava de uma perseguição política. Até mesmo o famoso coronel Erasmo Dias, em palestra realizada na União Cívica Feminina em São Paulo, denunciava que o caso do MEP era uma prova de que o "terrorismo estava se rearticulando" ${ }^{164}$. A mensagem anunciava a disposição de manter implacável perseguição aos opositores da ditadura.

Enquanto o delegado Borges Fortes pedia à Auditoria mais tempo para investigar o $\mathrm{MEP}^{165}$, os advogados Raimundo Moreira, Lino Machado Filho e Humberto Jansen de Melo representaram, no dia 04, à Auditoria, confirmando as acusações de Heleno Fragoso ${ }^{166}$.

161 O Globo, 17 de agosto de 1977.

162 Folha de São Paulo, 09 de agosto de 1977.

163 Folha de São Paulo, 12 de agosto de 1977.

164 Folha de São Paulo, 18 de agosto de 1977.

165 Folha de São Paulo, 07 de outubro de 1977.

166 Jornal do Brasil, 27 de outubro de 1977. A edição desse dia trazia informação de ação passada dos advogados. 
Luiz Eduardo Greenhalgh e Márcia Ramos de Souza, defensores de Aldo Arantes e Haroldo Borges, enviaram ofício à Ordem dos Advogados do Brasil, reafirmando as denúncias dos quatro advogados. Em resposta, o então presidente da Ordem Raymundo Faoro dirigiu-se ao ministro da Justiça, Armando Falcão, solicitando providências ${ }^{167}$. A investida das denúncias se intensificava, uma vez que os interrogatórios dos presos tinham sido marcados ${ }^{168}$.

Os órgãos oficiais de governo, por suas vezes, responderam aos questionamentos. O diretor do Departamento Geral de Investigações Especiais (DGIE), órgão ao qual se submete o DPPS, delegado José de Almeida Nicanor afirmou que "a alegação de maus-tratos e coação é uma constante para preparar a defesa, objetivando o desprestígio da confissão e das outras provas". Já a seção de Relações Públicas do I Exército anunciou que as denúncias tinham o "nítido propósito de tumultuar e confundir a opinião pública”"169.

A luta pela liberdade dos presos encontrou vários ecos. Foi exatamente nesse período que os presos publicaram uma carta de denúncia dos maus tratos ${ }^{170}$. Na Câmara dos Deputados, o líder do MDB, Álvaro Dias, apelou em favor dos militantes do MEP. Falou à imprensa que "o relato dos presos políticos no Rio de Janeiro é o mais chocante que já tivemos oportunidade de ver estampado na imprensa deste país"171.

A seção carioca da OAB, presidida por Eugênio Haddock Lobo, se dedicou ao caso, dando ênfase à necessidade de resgatar a figura do habeas corpus. O Comitê Brasileiro pela Anistia fez vasta campanha, que culminou com uma vigília em favor dos detidos. Cartazes eram colocados no Rio de Janeiro estampando as fotos dos

167 Jornal do Brasil, 27 de outubro de 1977.

168 Folha de São Paulo, 15 de outubro de 1977.

169 Jornal do Brasil, 27 de outubro de 1977.

170 Folha de São Paulo, 25 de outubro de 1977. A carta, repercutida em larga escala, segue na íntegra mais à frente.

171 Jornal do Brasil, 27 de outubro de 1977. 
militantes caídos nas garras da ditadura. Na PUC dessa cidade, o movimento estudantil organizou uma manifestação contra a tortura, que teve seu ponto auge ao queimarem uma "cadeira do dragão", instrumento através do qual dava-se choques elétricos. O MEP ganhou dimensão nacional. Era discutido nos jornais, nas universidades, entre os democratas. O pequeno grupo nascido da POLOP conseguiu expor a ditadura, de maneira a contribuir para o seu desgaste.

No fim do mês de outubro, por volta do dia 26, as militantes presas do MEP, ao lado de outras, iniciaram outra greve de fome. Elza Maria Pereira Lianza, Maria Cecília Barbosa Wetten, Maria Fátima Martins Pereira, todas do MEP, ao lado de Rosalice Magaldi Fernandes, Jéssie Jane Vieira de Sousa e Norma Sá Pereira Torres organizaram o movimento dentro do presídio feminino Talavera Bruce. Lá, não havia separação entre presas comuns e políticas. O regime disciplinar para as detentas políticas, dada a Lei de Segurança Nacional, era considerado mais brando que o das prisioneiras comuns, fato gerador de tensão. Argumentavam as grevistas em favor da segurança individual e do direito de serem tratadas como presas políticas, assim como os homens ${ }^{172}$. Exigiam, portanto, melhores condições de encarceramento e transferência para Frei Caneca, onde havia ala de presos políticos. Este ato de rebeldia teve grande impacto. Em solidariedade, os homens encarcerados no Instituto Esmeraldino Bandeira aderiram à greve de fome.

Em 01 de novembro, as presas foram transferidas para o Hospital Central Penitenciário ${ }^{173}$. A greve de fome durou treze dias. No dia 05, Elza Maria Parreira Lianza, Maria de Fátima Martins Pereira, Maria Cecília Wetten, Arhur Obino Neto e Ignácio Guaracy de Sousa Lemos tiveram as prisões preventivas relaxadas.

Os depoimentos começaram a ser marcados para a primeira quinzena de novembro. Seguem aqui alguns registros apresentados. Ao depor, no início de novembro, Ivan Valente afirmou ter sido colocado em uma "geladeira". Jogavam-Ihe baldes de água fria intercalados com sessões de espancamentos. Foi avisado ser um "prisioneiro de guerra" e que não sairia vivo dali. Em um dos momentos de 172 O Globo, 01 de novembro 1977. 173 O Globo, 01 de novembro 1977. 
choques elétricos, foi asfixiado com um capuz. Afirmou ao juiz que, naquele instante, achou que fosse morrer. Luiz Arnaldo, na Auditoria, confirmou que, para além das torturas habituais, foi pendurado pelas mãos por longos períodos. Disse também que agentes policiais roubaram instrumentos do cinema em sua casa. Por não ter assinado a confissão, voltou ao DOI-CODI. José Augusto passou pelos mesmos rituais. A "novidade" é que batiam a sua cabeça contra a parede. Sidney Lianza contou que tentaram violá-lo com um cacetete elétrico. Ameaçaram torturar a sogra. E consumaram a tortura de Elza Maria, sua esposa, nua, sentada na "cadeira do dragão", enquanto desferiam choques. A cena narrada é assombrosa. Sidney também estava sentado em uma cadeira em sala ao lado da de Elza. Ele podia ver a esposa quando iluminavam um vidro que separava os dois ambientes. Rodavam a cadeira de Sidney. Quando paravam, acendiam a luz. Na primeira vez, Elza apareceu em pé, vestida. Na segunda vez, nua ao meio sala. Na terceira, já estava sentada na "cadeira do dragão" com fios elétricos no corpo ${ }^{174}$.

Errol disse que por ter se recusado a assinar um testemunho apresentado pelo delegado, o mandaram de volta à Polícia do Exército. Foi torturado por mais dois dias. Queixou-se também que, após a incursão policial em sua casa, desapareceram roupas, filmadora, projetor de filmes e livros didáticos. Frederico José Galvão afirmou, na Auditoria, que por ser sobrinho do ministro da Justiça poderia sofrer represálias até mais agudas que as dos outros. Foi levado ao DOICODI. Foi espancado, embora não tenha recebido choques elétricos. A sua confissão foi assinada sob coação. Por sua vez, Fernanda Duclos Carísio, ao ser removida da Polícia do Exército, da rua Barão de Mesquita, sofreu um ataque de pânico e foi submetida a vexames que ela preferiu não contar em detalhes aos oficiais do Conselho de Justiça ${ }^{175}$. De fato, o grau de sevícia sofrido pelos militantes, mesmo no fim dos anos 1970, continuava sendo bárbaro. Em nova audiência, Maria Cecília comentou que foi presa em Rio Claro, São Paulo. Foi torturada no DOI-CODI da rua Tutoia, no bairro de São Paulo ironicamente, diante do caso, chamado 174 Folha de São Paulo, 11 de novembro de 1977.

175 Tais depoimentos foram publicados na edição de O Globo do dia 19/11/1977. A notícia também foi dada na Folha de São Paulo, na mesma data. 
Paraíso. Sofreu espancamentos e choques. Diabética, foi obrigada a comer açúcar. Alguns de seus torturadores respondiam por Nélson, Gouveia e Togo. Seu translado de São Paulo para o Rio de Janeiro foi feito sem ordem judicial, portanto, ilegal. Mais para frente, esta falha Ihe garantiu o relaxamento da prisão preventiva. José Mendes e Maria de Fátima, estudantes de medicina, narraram torturas e, como todos os outros, assinaram coagidos a confissão. Jorge José sofreu espancamentos, mas, felizmente, não chegou a cair nos porões do DOI ${ }^{176}$.

Aos poucos, os presos do MEP conseguiram na justiça o direito de responder em liberdade. $\mathrm{O}$ quadro pioraria de figura no próprio julgamento em si, que foi protelado algumas vezes, tanto por pedidos da acusação, quanto da defesa. Em fevereiro de 1978, o processo volta ao DPPS, sob alegação de que novos nomes tinham aparecido ${ }^{177}$.

No início de março, a defesa de Maria de Fátima entrou com representação na Auditoria, uma vez que a militante continuou sendo perseguida pelos membros da repressão. Houve até mesmo uma tentativa artificial de atropelamento. Luiz Arnaldo e Franklin Dias tomaram medidas semelhantes. Também no início março, o advogado Adibal Piveta, defensor de Ivan Valente, pediu adiamento do julgamento, alegando cerceamento ao direito de defesa. Foi aceito ${ }^{178}$. No dia 18 , a defesa de Errol pediu ao STM adiamento, alegando também cerceamento, uma que vez que uma testemunha arrolada não pôde ser ouvida. Mais uma vez, aceito ${ }^{179}$. Já em maio, o STM nega novo pedido de correição feito pela defesa de Ivan Valente ${ }^{180}$. A disputa judicial foi lenta, repleta de idas e vindas e movida a conflitos políticos de várias ordens.

176 O Globo, 25 de novembro de 1977.

177 O Globo, 14 de fevereiro de 1978.

178 O Globo, 03 de março de 1978. A Folha de São Paulo também comunicou a suspensão do julgamento pelo STM.

179 O Globo, 18 de março 1978.

180 O Globo, 11 de maior de 1978. 


\subsection{De mãos dadas}

"Cada voz que se levanta para protestar contra as prisões e os assassinatos políticos exigindo a libertação de nossos presos é uma voz que faz crescer as lutas populares pelo fim da opressão"181.

Essas são as palavras grafadas em um cartaz que abre o documentário "De Mãos Dadas" sobre a campanha pela libertação dos presos do MEP. A iniciativa foi dirigida por Ivan Viana, quem contou com a ajuda de muitas outras pessoas. A produção independente ocorreu no contexto do jornal O Companheiro, em agosto de 1979.

Como não poderia ser diferente, as imagens são de 1977 e 1978. Revelam as faces daqueles que se indignavam com a prisão dos jovens. Mostra a angústia e a esperança que coabitavam o final dos anos 1970. O documentário tem como linha uma narração que descreve as prisões, a tortura e a luta pela liberdade. Entrecortadas, aparecem imagens de alguns momentos. Manifestações contrárias à ditadura. Pequenos protestos envolvendo categorias profissionais em que, aliás, o MEP tinha trabalho de base, como o SEPE (Sindicado Estadual dos Profissionais de Educação) e os metalúrgicos de Niterói. Pichações. Colagens de cartazes e lambelambes. Vários deles com a imagem dos rostos dos detidos.

Todavia, há dois momentos cruciais revelados pelas lentes da V8. Um atovigília do Comitê Brasileiro pela Anistia, que ocorreu na sede da Associação Brasileira de Imprensa $(\mathrm{ABI})$, às vésperas do julgamento, no dia 11 de dezembro de 1978. Lotado. Centenas de pessoas, a maioria, jovens. Falas inflamadas. Chamamentos para a luta. Atenção. Um jovem, com as veias saltadas, falava a plenos pulmões. O Terceiro Reich prometera ficar mil anos. Não durou dez. A ditadura por aqui não tardaria a cair. O ânimo explode entre os presentes. Anistia, ampla, geral e irrestrita era gritada, ao lado de outras palavras de ordem. O outro

181 DE MÃOS dadas. Direção de Ivan Viana e André Lázaro. Rio de Janeiro: Produção Independente, 1981, DVD. 
momento foi durante o julgamento dos presos na I Auditoria da Aeronáutica. Entre 500 e mil pessoas estavam presentes, cercadas por coturnos e baionetas. A esperança se frustra com a condenação que, passados poucos meses, caiu por terra.

O documentário encerra com uma música de Milton Nascimento de onde extrai seu título. "Vamos, caminhando de mãos dadas com a alma nova/_Viver semeando a liberdade em cada coração/ Tenha fé no nosso povo que ele acorda/ Tenha fé no nosso povo que ele assusta". Os versos são da música "Credo", de 1978. Clube da Esquina 2.

\subsection{Dos acusados}

O promotor Gastão dos Santos Ribeiro ofereceu denúncias contra os seguintes militantes ${ }^{182}$. Elza Maria Parreira Lianza teria começado sua atividade política em 1977, quando passou a frequentar o Sindicato dos Engenheiros. Em aparelhos do MEP, ela formulava políticas para a comissão de cultura desse sindicato. Inácio Guaracy de Souza de Lemos trabalhava com vendedor de café na praia. Foi, segundo a polícia, aliciado por Ivan Valente, cujo cognome era "Matheus". Valente pagou a Guaracy um curso de eletricista-instalador, o qual the valeu um emprego em um estaleiro. Com isso, sindicalizou-se no sindicato dos metalúrgicos. Frequentava as reuniões com assiduidade e repassava as informações a "Matheus". O terceiro denunciado foi Arthur Orbino Neto. Arthur interessava-se por política desde de 1969, embora não tenha participado do movimento estudantil. Sua atuação concreta se destacou na pós-graduação, mais especificamente na Coordenação dos Programas de Pós-Graduação de Engenharia (COPPE). Entrou no MEP no início de 1976. De acordo com a investigação, contribuía com a organização com valores altos. Franklin Dias Coelho, o quarto acusado, era o responsável pelo Setor Interno do MEP. Socialista desde o início dos anos 1970, entendia que o objetivo do MEP

182 As informações a seguir foram extraídas do Jornal do Brasil de 27 de outubro de 1977 e da denúncia que consta no BNM_700. 
era a construção do "governo dos trabalhadores do campo e da cidade". André Teixeira Moreira entrou na organização em 1975, com o objetivo de "atender seus pendores socialistas". O intermédio de sua entrada se deu por Frederico José Falcão, sobrinho do ministro da Justiça Armando Falcão.

Cláudio Rocha Roquete compunha o Comitê Estudantil, ao lado de André Teixeira Moreira e Frederico José Falcão. Sua responsabilidade, dentre outras, era fazer chegar à UFRJ documentos da organização e auxiliar a disputa da linha política no movimento estudantil. Simpatizante de ideias comunistas e opositor à direção do Sindicato dos Bancários, Errol Dias Peçanha compunha oposição sindical, chamada União Bancária. Qualificado como perigoso e notório agente da subversão, Ivan Valente, o oitavo denunciado, participou de reuniões em que foram aprovados teses e estatutos do MEP. Dos mais novos entre os envolvidos, Luiz Arnaldo Dias Campos participava do grupo desde 1975 e chegou a participar da conferência regional do movimento. Frederico José Falcão, leitor de Marx e Lênin, declarou-se elemento de peso da organização, embora tenha se afastado dela em janeiro de 1977.

Outra mulher denunciada, Fernanda Carísio compunha o setor estudantil do MEP, tendo entrado em 1975. Ao seu lado, Maria Cecília Barbosa Watten entrou no MEP em 1974, sendo ela professora. Na casa de Sidney Lianza foi encontrado farto material subversivo. José Mendes Ribeiro e Maria de Fátima Martins faziam parte do Setor Estudantil, como quase todos os outros, tendo ela participado da Semana pelos Direitos Humanos da UFF. O último denunciado foi José de Melo, chamado de Gabriel. A polícia o apresenta como militante fervoroso e diligente. Assistiu a assembleias na PUC e reuniões do Comitê $1^{\circ}$ de Maio.

\subsection{Carta dos presos}

Muitos são os registros das bárbaras violências de Estado cometidas contra grupos de oposição à ditadura militar. O MEP, nesse caso, faz parte da estatística. No entanto, há uma particularidade: o MEP foi o primeiro grupo a fazer com que uma 
carta de denúncias das torturas sofridas, escritas pelos torturados, fosse publicada em jornal aberto, ainda com seus militantes na cadeia. A carta foi impressa na edição de 27 de outubro de 1977, no Jornal do Brasil. As repercussões foram imensas. A tortura como prática sistemática da ação do Estado era revelada aos sete ventos. Os presos escreveram-na em condições terríveis. Evidentemente, não tinham acesso a papel e caneta. Com pequenos lápis, escreviam trechos em pequenos fragmentos, retirados da prisão nos corpos das mães, irmãs e amigas. Elas remontaram o texto e enviaram-no à imprensa. Pelo impressionante impacto da leitura, reproduzimos na íntegra o documento ${ }^{183}$.

"Temos assistido, nos últimos dias, às sucessivas denúncias de torturas a que são submetidos presos políticos detidos em órgãos de segurança. As primeiras denúncias, veiculadas através de noticiários da imprensa, davam conta das torturas sofridas por estudantes e operários presos em São Paulo, em abril, principalmente Márcia Basseto Paes e Celso Brambilla, este tendo praticamente perdido a audição.

Depois, vieram à tona as descrições das torturas infames a que fomos submetidos no DOICODI-RJ, descrições confirmadas por Aldo Arantes e Haroldo Borges em carta à imprensa, na qual dizem ter passado pelo mesmo órgão policial-militar e sofrido as mesmas torturas que nós. Os mesmos, em petição encaminhada à Justiça Militar (O Globo, 2/9), relataram o martírio sofrido durante quase dois meses nos subterrâneos de órgãos de segurança de São Paulo e do Rio, verdadeiros laboratórios científicos de tortura. Em 3/9, o JORNAL DO BRASIL publicou carta em que Manoel Henrique Ferreira relatava as bárbaras torturas que quase o levaram à tortura, digo, loucura e através das quais Ihe foi arrancado um "arrependimento público".

Todavia, as denúncias sobre a violência policial mostram que ela não se abate somente sobre os presos políticos e que, pelo contrário, é uma ameaça permanente à maioria da população. O caso do operário Jorge Defensor, barbaramente torturado numa dependência policial em Belo Horizonte, por 17 policiais, acabando inutilizado para o resto da vida, com a espinha partida em três pontos e com os órgãos genitais destruídos, é apenas um exemplo entre muitos.

E, hoje, quando surgem de todas as partes denúncias das infames torturas e da violência policial que se abate sobre os que lutam por melhores condições de vida e trabalho e pelo direito de se organizarem e manifestarem livremente, violência que se estende a todo o sofrido povo brasileiro, sujeito cotidianamente a todo tipo de arbitrariedades e humilhações, julgamos nosso dever hipotecar a mais irrestrita solidariedade a todos aqueles que, como nós, são vítimas da selvagem repressão policial e a todos os que se empenham numa luta pelo fim das torturas.

Na qualidade de presos políticos, julgamos da maior oportunidade engrossar as vozes que denunciam as torturas como uma prática sistemática e a opressão policial com instrumento que se presta a perpetuar a situação de miséria e exploração em que se encontram os trabalhadores brasileiros. Nesse sentido, passamos a relatar, aqui, fatos ocorridos durante nossa passagem pelos órgãos policiais.

Nossas prisões ocorreram entre os dias 19 de julho e 2 de agosto e, levadas a cabo sem qualquer mandado ou instrumento legal, foram, em verdade, autênticos sequestros, com o

183 A íntegra da carta encontra-se em Jornal do Brasil, 27 de outubro de 1977. 
emprego de violência nas detenções, invasões de domicílios e sangue em diversas residências. Do apartamento do companheiro Franklin Dias Coelho, por exemplo, foram levados móveis, eletrodomésticos e utensílios de cozinha. Do mesmo modo, da casa do companheiro Errol Dias Pessanha desapareceram uma filmadora e um projetor de cinema, não ficando até agora esclarecido que tipo de prova a polícia deseja obter com a apreensão desses objetos.

Uma vez presos, fomos atirados em carros, imediatamente algemados e encapuzados e conduzidos a um local que, mais tarde, viemos a saber tratar-se do DOI-CODI-RJ. Lá após termos sido despidos e fotografados, seguimos debaixo de espancamentos para as geladeiras ou para as salas de interrogatórios, iniciando-se, dessa maneira, os nossos 10 dias de isolamento e tormentos.

Durante esse período, tendo ficado até quatro dias sem comer ou dormir, com frequência éramos cercados por vários torturadores e, debaixo de insultos e ameaças, recebíamos de toda parte violentos golpes que, não raro, nos derrubavam. Totalmente amarrados a cadeiras, fomos submetidos a intermináveis sessões de choques elétricos em todas as partes do corpo, muitas vezes acompanhados de socos, pontapés e pauladas. Nas ante-salas das geladeiras (cubículos de 0,5m x 1,5), ficamos longas horas algemados pelas costas ou pendurados pelas algemas, convivendo, na escuridão, com as baratas e ouvindo os gritos dos companheiros que estavam sendo torturados.

Nessas e numa infinidade de outras situações em que nossos verdugos procuravam nos humilhar e aterrorizar, seu objetivo maior era nos abater, física, moral e psicologicamente. A cada ato de resistência, nossos algozes respondiam com o aumento infinito da tortura, com prolongamento das sessões de choques, com aumento da corrente elétrica, ameaças de paude-arara, tentativas de estupro, enfim, todo tipo de chantagem e bestialidade era empregado com o fim de nos aniquilar e dobrar qualquer resistência que opuséssemos àquelas iniquidades.

A geladeira é uma cabina de cimento refrigerada, com revestimento de Eucatex acústico, colocada no interior de um compartimento maior de concreto e hermeticamente fechada por portas de frigorífero. Lá dentro, os movimentos do preso são controlados por um circuito interno de TV. Um sistema de som que emite ruídos estridentes e de alta frequência e o frio intenso, acompanhado de baldes de água gelada, completam as características dessa máquina de fazer loucos em que éramos espancados e torturados.

Foi aí que o companheiro José Augusto Dias Pires padeceu do que os torturadores diziam ser a cruz. Com os braços abertos e encostado à parede, seguro por dois homens, esse companheiro recebeu várias joelhadas nos testículos, enquanto um torturador se divertia em arrancar cabelos do seu púbis. Durante todo o tempo em que durou o suplício, um dos torturadores gracejava, dizendo a José Augusto que se consolasse, porque ia morrer "igualzinho a Jesus Cristo".

Também na geladeira, a companheira Maria de Fátima Martins Pereira, após permanecer várias horas com as pernas abertas e braços erguidos, foi atacada por cinco homens, que, forçando-a a deitar-se no chão e segurando-a pelas pernas e braços, tentaram enfiar em sua vagina um objeto de madeira semelhante a um cabo de vassoura, que a companheira foi obrigada a apalpar. Tentativas semelhantes de violentação sofreram os companheiros José Mendes Ribeiro e Fernanda Ducios Carisio, sendo que esta foi forçada a passar as mãos pelo corpo de um torturador despido e ameaçada de violação com um cassetete elétrico, com o qual aplicavam-Ihe choques nos seios, pernas e costas.

Foi em uma dessas geladeiras, em cujo chão imundo são visíveis grandes manchas de sangue, que vários de nós vimos o nome de Aldo Arantes riscado a unha no eucatex, prova pequena, porém cabal, das denúncias formuladas pelo próprio Aldo e por Haroldo Borges à Justiça Militar de São Paulo e publicadas em O Globo de 2 de setembro. 
Nas salas de interrogatório, cujas paredes são forradas com material acústico e com portas idênticas às das geladeiras, estão instaladas cadeiras semelhantes às de barbeiros, apelidadas pelos torturadores com o sugestivo nome de dragão. Nessas cadeiras, amarrados pelos tornozelos, braços, tórax e, alguns, até pelo pescoço, com correias de couro revestidas com espuma, para não deixar marcas, sofremos choques elétricos aplicados por fios ligados a uma Maricota, pequeno instrumento que, por meio de uma manivela, aumenta a intensidade da corrente elétrica.

Frequentemente, os choques eram acompanhados de espancamentos e o companheiro Ivan Valente, por exemplo, recebeu choques no canal da uretra e no ânus, simultaneamente, enquanto era asfixiado com o capuz e recebia repetidos pontapés no tórax e no abdômen. Franklin Dias Coelho, em alguns momentos, teve fios enrolados nos pés e nas mãos, ligados a duas maricotas, além de presilhas nos órgãos genitais. Com outro fio, percorriam seu corpo, desde o lóbulo da orelha até o pé e foram feitas tentativas de colocar o fio nas gengivas. Do mesmo modo, os companheiros André Teixeira Moreira, Sidney Lianza, Artur Obino, Luiz Arnaldo Campos e Inácio Guaracy também foram espancados durante sessões de choques, alguns com cassetetes forrados de espuma, que, segundo os torturadores, "não deixava marcas e só quebrava por dentro".

Após uma sessão de choques, o companheiro Sidney Lianza foi ameaçado de que sua esposa e sua sogra também seriam torturadas. Como duvidasse, foi levado a uma sala, de onde sentado numa cadeira giratória, pôde ver, através de um retângulo de vidro, sua mulher, Elza Lianza, ser despida e sentada no dragão. Após ouvir uma série de ameaças, inclusive de que Elza seria currada, Sidney viu a esposa receber choques na vagina, ao mesmo tempo que em alto-falantes traziam para a sala onde estava os gritos de sua mulher e os insultos dos torturadores. Depois de alguns minutos, o bestial espetáculo encerrou-se e Sidney foi reconduzido a outra sala, para continuar a ser espancado.

Na ânsia de nos arrancar informações, os órgãos de segurança cometeram violências até contra nossos familiares. Dona Esterina Roberto Parreira, carioca de 65 anos, mãe de Elza e sogra de Sidney, só não foi presa por ter sofrido um mal-súbito no momento em que os policiais davam-Ihe voz de prisão no interior da casa de sua filha. Já Dona Rosalina Madeira Wetten (61 anos) e Maria Antônia de Madeira (56 anos), mãe e tia de Maria Cecília Wetten, foram presas no dia 31 de julho, no Rio, e conduzidas para o DOI-CODI, onde ouviram ameaças de choques elétricos e quase foram despidas à força. As duas só foram liberadas 12 horas depois, trocadas por Maria Cecília, presa em Rio Claro (SP).

Após sua prisão, Maria Cecília foi conduzida de carro para o DOI-CODI do II Exército, na cidade de São Paulo. Logo ao chegar, foi espancada com tapas nos ouvidos e golpes na nuca e submetida a violentos choques elétricos, aplicados com panos molhados, enquanto jogavamIhe água sobre o corpo. No segundo dia, tornou a sofrer choques elétricos de pé e sem qualquer apoio. Os choques eram tão fortes que contraiam seu corpo e faziam-na cair, além de enrolar sua língua, provocando sufocação. Em virtude desse tratamento, a companheira perdeu a coordenação das pernas por oito dias. Na tentativa de esconder os maus-tratos, ainda em São Paulo, antes de ser transferida para o DOI-CODI no Rio, Cecília foi filmada na cama e comendo, como se isso pudesse, de alguma forma, ocultar os tormentos pelos quais ela passou.

Como forma de tortura psicológica, a ameaça de assassinato sumário foi muito utilizada e, a todo momento, nos diziam que, em caso de morte, nossos corpos desapareceriam sem deixar vestígios. Nos últimos dias de isolamento, no DOI-CODI, o companheiro Luiz Arnaldo foi avisado de que, se, ao sair dali, procurasse "subornar" jornalistas para denunciar torturas, viraria um presunto. Antes de sair, o torturador acrescentou que "isso não é uma ameaça, é um fato". No último dia de incomunicabilidade, Maria Cecília também foi ameaçada de morte. Depois de morta, colocariam em sua bolsa um revólver 38 e maconha e abandonariam o corpo 
em Nova Iguaçu, atribuindo o crime ao Esquadrão da Morte ou Aliança Anticomunista Brasileira.

Durante as torturas, nossos inquisidores não escondiam seu orgulho com o aparato científico de que dispõem e, frequentemente, se vangloriavam de possuir "moderna tecnologia de torturas físicas e psicológicas" e de seus "trabalhos cientificamente dosados". Para vários de nós, afirmaram que o som produzido nas geladeiras é capaz de provocar reações orgânicas como enjoo e vômitos e até loucura. Gabando-se de estar "exportando tecnologia", a preocupação de nossos algozes com a "cientificidade" da tortura incluía comparações com os métodos de outros órgãos de segurança, do tipo "aqui não ocorrem mortes como em São Paulo".

E uns poucos fatos podem demonstrar até que ponto a ciência e a técnica podem ser postas a serviço dos mais torpes objetivos. O companheiro Claudio da Rocha Roquete, com problemas cardíacos, veio a desmaiar na geladeira, após sofrer violentos golpes no tórax e no abdômen e ficar dependurado pelas algemas, durante horas. O médico que o examinou limitou-se a recomendar um período de descanso fora da geladeira e o companheiro continuou sem ter acesso aos remédios que seu pai Ihe enviava, através do DPPS. Segundo os torturadores, não poderia tomá-los por estar de castigo. No mesmo sentido, vários de nós tivemos a pressão arterial medida durante as sessões mais prolongadas de choque, apenas para comprovar a possibilidade ou não da continuidade dos suplícios. E, ainda, como exemplo, o companheiro Ivan Valente, no último dia de sua permanência no DOI-CODI, foi massageado no tórax com uma pomada, que visava minorar as marcas que Ihe tinham ficado das torturas.

Se os fatos que narramos até aqui não fossem suficientes para esclarecer que tipo de moral guia o comportamento de nossos algozes, suas próprias palavras deixariam claro a ideologia que professam. Afirmavam seu desprezo e ódio à classe trabalhadora, caracterizando os operários como "gente negligente, que só pensa em cachaça e não progride socialmente porque não quer". Satirizavam os direitos humanos, deixando claro que os únicos direitos que se cumprem no DOI-CODI são os dos torturadores, e qualificavam os advogados dos presos políticos como "subversivos", defendendo a eliminação destes. Faziam questão de deixar claro que contavam com os 10 dias de incomunicabilidade para fazer com os presos o que bem entendessem, "sob as garantias da lei". Consideravam a tortura não só uma profissão, mas uma "dever cívico". Diziam torturar "por princípio" e por serem patriotas" e, ainda mais, que "se tudo fosse deixado em suas mãos, o serviço seria completo: não sobraria ninguém".

Passados os dias de incomunicabilidade no DOI-CODI, fomos transferidos para o DPPS, onde, no dia 30 de julho, tivemos acesso, pela primeira vez, aos nossos familiares e advogados, sendo informados de que, oficialmente, tínhamos ficado detidos todo o tempo nessa delegacia, sem sofrer qualquer espécie de coação. O que há de falso nessa versão ficou mais do que demonstrado com os fatos acima narrados e dispensa outros comentários. Mas, por outro lado, é importante frisar que a vinda para o DPPS de maneira nenhuma representou o fim das nossas privações. No dia 01/08, os companheiros Errol Dias Peçanha e Luiz Arnaldo Dias Campos e sua mulher, Margareth da Silva, foram retirados de suas celas e reconduzidos ao DOI, onde permaneceram cerca de 40 horas. Margareth foi ameaçada de estupro e torturada com choques elétricos nos dedos dos pés e das mãos, enquanto os outros dois companheiros permaneciam o tempo todo nas geladeiras, sendo interrogados. Em defesa de nossos companheiros, entramos em greve de fome, exigindo sua volta imediata e garantias de que não voltaríamos ao DOI-CODI para sermos torturados. A luta deu seus frutos: no dia 03. ao meio-dia, os companheiros haviam retornado. Mesmo assim, a greve de fome continuou por quatro dias, até que suas repercussões na imprensa, nas Universidades e na lgreja e a abertura de inquérito no I Exército nos deram garantias relativas de que a volta ao DOI-CODI não se repetiria.

Durante nossa permanência no DPPS, a autoridade policial tem-se empenhado em criar um clima de insegurança e apreensão, com inúmeras ameaças de retorno ao DOI-CODI, e 
lançado mão de medidas como isolamento de companheiros em celas individuais, só quebrado recentemente. Esses fatos contrastam com as tentativas de conferir aos depoimentos uma aparência de normalidade.

Refutamos, também, os exames de corpo de delito realizados para apurar nossas denúncias de tortura e que só foram feitos 20 dias após nossa prisão, quando a maioria das marcas já haviam desaparecido e quando o legista recusava-se a registrar as que ainda existiam no corpo de vários companheiros.

Nós, abaixo-assinados, tendo passado por todas essas infâmias, achamos que, mesmo com a possibilidade de represálias, é nosso dever não calar ou omitir nosso testemunho de tais barbaridades, conscientes de que só assim estaremos dando uma contribuição, por pequena que seja, pelo fim definitivo das torturas em nosso país. Estamos dispostos a reafirmar estas declarações em Juízo ou frente a qualquer pessoa ou organismo idôneo que se disponha a averiguar estas denúncias.

(a) Elza Maria Parreira Lianza, Maria de Fátima Martins Perereia, Maria Cecília M. Wetten, Franklin Dias Coelho Guaracy, Sidney Lianza, Arthur Obino Neto, Inácio Guaracy Souza dde Lemos, Luiz Arnaldo Dias Campos, Cláudio da Rocha Roquete, André Teixeira Moreira, Ivan Valente, José Augusto Dias Pires, Fernanda Duclos Carisio, Frederico José Falcão e José Mendes Ribeiro".

A repercussão das prisões fez com que as forças de segurança perdessem a confiança em Borges Pontes, delegado responsável pelo inquérito e chefe do DPPS. Borges foi demitido do cargo ${ }^{184}$.

\subsection{O desenvolvimento do processo}

A denúncia oferecida pelo procurador Gastão dos Santos Ribeiro, para além das arbitrariedades habituais do funcionamento da Justiça Militar, possuía várias fragilidades. A alguns denunciados, o crime imputado foi do artigo 14 da Lei de Segurança Nacional, relacionada à formação de organização subversiva sob orientação ou auxílio de governo estrangeiro ou organização internacional. Outros foram acusados pelo crime do artigo 43, o qual implica na tentativa de reorganização de partido suspenso. Este, por si só, se configura absurdo, uma vez que o MEP nunca tivera existência legal. Ora, se todos os acusados faziam parte do MEP, os crimes imputados deveriam ser o mesmo para todos, aponta Heleno Fragoso ${ }^{185}$.

184 Folha de São Paulo, 08 de outubro de 1977.

185 Fragoso, Cláudio Heleno. Advocacia da liberdade. Editora Forense. Rio de Janeiro, 1985. Pg.169. 
No que tange à instrução criminal, um dos policiais arrolados como testemunhas, Nahil Jorge Hauat, quem supostamente teria sido executor de buscas e apreensões, dizia não se lembrar de nenhum detalhe e que as diligências foram feitas sem mandado, portanto, ilegais. Na verdade, quem fez buscas e apreensões foram membros do DOI-CODI. A defesa, por sua vez, foi impedida de fazer perguntas a uma testemunha por ela própria arrolada, no caso, Ricardo Soares Paniago, quem tinha passado pelo mesmo tratamento no DOI-CODI dado aos militantes do MEP. Questões como "em qual circunstância foi preso", "para aonde foi levado", "se foi submetido a algum tipo de violência" foram barradas, o que implica no cerceamento do direito de defesa ${ }^{186}$.

Os dias que antecederam o julgamento foram de grande movimentação política em defesa dos acusados. O Comitê Brasileiro de Anistia, ao lado da militância do MEP e de outros defensores da democracia, colavam cartazes que denunciavam as arbitrariedades e convocavam para a manifestação à frente da Auditoria no dia do julgamento. No dia 05 de dezembro, seis estudantes foram detidos, ao serem pegos em flagrante colando os cartazes, nos bairros de Copacabana e Botafogo. Foram eles Fernando Antônio de Vinhaes, Nelson Porto Ribeiro, Verônica Dias Rocha, Vanda Martins, Mauro Cleman Sá de Araújo e Paulo Sérgio Couto ${ }^{187}$.

No dia dez, em ato organizado pelo Comitê Brasileiro pela Anistia de São Paulo, na Câmara Municipal de São Paulo, foi celebrada comemoração pelo $30^{\circ}$ aniversário da Declaração Universal dos Direitos do Homem. 250 pessoas estiveram reunidas. $A \mathrm{ABI}$, a Associação dos Docentes da USP (ADUSP), a Associação dos Médicos Sanitaristas, a Oposição Metalúrgica, o DCE da USP, a União Estadual dos Estudantes e militantes do MEP e da Convergência Socialista estiveram presentes. O deputado do MDB, Geraldo Siqueira Filho, defendeu o MEP. "Essas pessoas estão sendo acusadas por terem defendido bandeiras como o fim do arrocho salarial, pela liberdade de organização e expressão, bandeiras que são 
necessidades da população brasileira" ${ }^{188}$. Ainda em São Paulo, foi articulado um manifesto em defesa dos militantes acusados, assinado pelo CBA-SP, Sindicato dos Artistas e Técnicos em Espetáculos de Diversão no Estado de São Paulo, o Jornal Brasil Mulher, os centros acadêmicos Oswaldo Cruz e Pereira Barreto, a Associação de Médicos Residentes no Estado de São Paulo, os DCEs da USP e da PUC e a União Estadual dos Estudantes (UEE) ${ }^{189}$.

O Comitê Brasileiro pela Anistia do Rio de Janeiro havia preparado uma vigília cívica, que começou no dia 11 de dezembro, no auditório da Associação Brasileira de imprensa. 600 pessoas lotavam o espaço. Uma das militantes à frente da movimentação era Iramaya Benjamin, principal articuladora da Anistia no Brasil e mãe de César e Cid Benjamin, ambos militantes do MR-8 barbaramente torturados e exilados. Na vigília, vários parlamentares da ala "autêntica" do MDB falaram, além do presidente da ABI, Barbosa Lima Sobrinho, o presidente do DCE da UFRJ, Roberto Bittencourt e uma representante da Associação dos Médicos e Residentes do Estado do Rio de Janeiro, Marta Costa ${ }^{190}$. Além dos debates, foi passado o filme "Nada será como antes", de Maria Helena Saldanha. Várias apresentações artísticas ocorreram, com apresentações dos teatros da UERJ e da PUC, e atrações musicais, com os artistas Alceu Valença, Zezé Mota, João de Aquino, Carlos Vergueiro e Alcione ${ }^{191}$ Após passarem a noite inteira reunidos, no dia seguinte, marcharam em grupos pequenos, de modo a não configurar passeata, até a avenida Marechal Câmara, local da I Auditoria da Aeronáutica. Era chegada a hora da audiência.

A instrução penal havia se constituído da seguinte maneira. $O$ inquérito foi instaurado do DPPS, sob o comando do delegado Francisco Borges Fortes. Da parte da acusação, três policiais também do DPPS foram arrolados como testemunhas. Da defesa, houve o interrogatório dos 17 acusados. Vários recursos foram impetrados, de modo a garantir que as testemunhas de defesa falassem.

188 Folha de São Paulo, 11 de dezembro de 1978.

189 Folha de São Paulo, 10 de dezembro de 1978.

190 O Globo, 12 de dezembro de 1978.

191 Folha de São Paulo, 12 de dezembro de 1978. 
Incidentes ocorreram. Conflitos entre o Ministério Público Militar e os juízes do Conselho da I Auditoria e mesmo suspeita de ataque a bomba, no início do processo.

Em julgamento, os presos do MEP. Os advogados de defesa eram Augusto Sussekind de Moraes Rego (decano da Justiça Militar), Alcione Barreto, Manuel de Jesus Soares, Eny Raimundo Moreira, Humberto Jansen Machado Nélio Machado, Heleno Cláudio Fragoso e Idibal Piveta (este de São Paulo). A sessão foi iniciada às 10 e 20 da manhã. Estava marcada às nove horas. Atrasou, pois os advogados relutaram para não serem revistados. O promotor militar, Gastão dos Santos, apresentou suas provas, fazendo questão de reafirmar a ausência de torturas e que a única coação vista vinha da manifestação do lado de fora, que buscava pressionar o Comitê de Justiça. Todos os advogados argumentavam em torno da ilegalidade das provas produzidas. As atividades no prédio da Aeronáutica foram suspensas. Poderiam entrar somente seguranças e credenciados, em número de 40. Dois parentes de cada acusado e seis jornalistas. Tendo em vista a repercussão internacional, a advogada portuguesa Vera da Silva acompanhou o julgamento, em nome da Anistia Internacional, ao lado de outras associações de classe ${ }^{192}$ Os indiciados entraram no prédio pela porta da frente, com os punhos cerrados em direção aos manifestantes. Essa cena foi capitada pelas lentes fotográficas. Os 17 foram recepcionados primeiro com uma grande salva de palmas dos manifestantes. Depois, em silêncio, estes ergueram seus braços com o $\mathrm{V}$ de vitória, símbolo da luta pela anistia. Na rua, forte presença de soldados e policiais ${ }^{193}$.

Ao meio-dia, quando do intervalo do julgamento, Abigail Paranhos, representante do CBA, ao se informar da situação com os advogados, repassou os informes aos manifestantes. Às 13 horas, quem veio Ihes falar foi um dos acusados, Luiz Arnaldo Dias Campos. À noite, os manifestantes voltaram à sede da $A B I$. Embora com presença militar ostensiva, nenhum registro ocorreu do lado de fora. A sentença demorou a sair.

192 Folha de São Paulo, 12 de dezembro de 1978.

193 O Globo, 13 de dezembro de 1978. 
Quando saiu, revolta. A sentença condenava dez dos acusados a penas que variavam entre dois e três anos de reclusão. Sete foram absolvidos. Houve um voto vencido, o do auditor Mário Moreira de Souza. Ao ser anunciada, a decisão gerou imediato furor. Os condenados subiram na mesa do júri aos gritos de "abaixo a ditadura!"194. Somente no dia 08 de janeiro foi feita a leitura pública da sentença condenatória. Maria Cecília, Errol, José Mendes, Elza Maria, José Augusto, Fernanda Duclos e Maria de Fátima foram absolvidos por falta de provas. $\mathrm{Na}$ sentença pública, ficava clara a indignação dos ministros militares com as manifestações realizadas em defesa dos presos. Apresentaram repúdio "às atividades intempestivas, desrespeitosas à Justiça, demonstrativas de nenhum arrependimento dos acusados que, em flagrante desprestígio das autoridades judiciárias que os julgou, dão ilações de suas conveniências com os manifestantes que estavam frente ao local de julgamento"195.

De imediato, começou a reação na sociedade. A vigília saiu em direção à sede da $A B I$, reunindo-se, em seguida, na Casa do Estudante Universitário, para discutir as condenações dos dez membros do MEP ${ }^{196}$. 300 pessoas estiveram presentes. $\mathrm{O}$ deputado estadual Raymundo de Oliveira e advogados apareceram. Idibal Piveta informou que a defesa impetraria novo pedido de Habeas Corpus, baseado na Lei 6544 do Código de Processo Penal Militar, o qual garante que o condenado, com bom comportamento, responda em liberdade até a conclusão do processo em segunda instância ${ }^{197}$. Colegas de trabalho de Frederico José Galvão organizaram um abaixo-assinado contra as prisões, isso no centro de pesquisa e documentação da Fundação Getúlio Vargas ${ }^{198}$. No documento, diziam "solidarizamo-nos com os condenados e esperamos a condenação desse ato injusto, reivindicando o restabelecimento das liberdades democráticas, para que cada brasileiro, quaisquer

\footnotetext{
194 Fragoso, Cláudio Heleno. Advocacia da liberdade. Editora Forense. Rio de Janeiro, 1985. Pg.173. 195 Jornal do Brasil, 09 de janeiro de 1979.

196 Folha de São Paulo, 13 de dezembro de 1978.

197 O Globo, 14 de dezembro de 1978. Folha de São Paulo, 15 de dezembro de 1978. 198 O Globo, 16 de dezembro de 1978.
} 
que sejam suas convicções políticas, possa viver e pensar livremente em nosso país" ${ }^{199}$ No dia 14, a defesa entrou com habeas corpus no Superior Tribunal Militar.

Vale registrar que a decisão de participar do julgamento, por parte dos militantes, foi política. Sabiam que a chance de condenação era muito alta. Todavia, os presos políticos fizeram a leitura de que a ditadura estava desgastada e que em algum momento, não se sabia ao certo, chegaria a anistia. Resolveram apostar. Ao aceitarem o risco iminente da prisão, diante das arbitrariedades públicas, foi uma aposta na aceleração da queda da ditadura militar ${ }^{200}$.

No dia 14 de dezembro de 1978, o jornalista da Folha de São Paulo, Ricardo Arnt, escreve uma matéria em que relata a dimensão que assumiu essas prisões. Com o título "As denúncias do processo do MEP marcaram época" ${ }^{201}$, estabelece impressionante síntese. Dado o vigor das palavras e com o objetivo de entender o espírito do tempo, reproduzimos aqui, na íntegra, o texto.

“O processo do Movimento pela Emancipação do Proletariado, de certa forma, baliza uma época. Nenhum outro foi tão exposto à opinião pública, embora, a rigor, não exista nada que o diferencie profundamente dos outros processos de subversão dos últimos dez anos. Apenas, deu-se num momento em que a sociedade civil começa a rearticular-se. A história de sua repressão, em julho de 1977, noticiada amplamente como nenhum outro, por uma imprensa com uma nova responsabilidade, e os métodos dos órgãos de segurança nada têm de novo. Apenas, seu erro foi tê-los repetido num momento político onde já não poderiam mais ser tolerados.

Da mesma forma, a condenação de 10 dos 17 acusados, considerada surpreendente num processo tão cheio de irregularidades e escândalos, e, agora, nem tão surpreendente assim, responde à primeira tentativa de julgar o regime, denunciando-o pela criminalização do politico. A campanha de denúncia e 199 Folha de São Paulo, 16 de dezembro de 1978.

200 Entrevista concedida por Ivan Valente em 06 de abril de 2019.

201 Folha de São Paulo, 14 de dezembro de 1978. 
mobilização contra o julgamento, feita no Rio há alguns dias, com cartazes nas ruas e uma multidão de 500 pessoas em frente à auditoria no dia do julgamento, a Justiça Militar respondeu com uma manifestação de força, habilmente exigida pela promotoria. Entre os dois pólos antagônicos, o único elemento comum é, ainda, o choque.

A opinião pública acompanhou o processo do MEP nos principais jornais do país. Em julho de 1977, sem mandatos legais e armados de metralhadora, a polícia invadiu residências, levando presas 26 pessoas, a maioria estudante, com idade média em torno dos 25 anos. Apenas um operário._Muitos foram sequestrados em plena rua, sob olhares atônitos de populares. Em várias casas houve "saques": a polícia simplesmente "expropriou" móveis, eletrodomésticos, utensílios de cozinha, uma filmadora e um projetor de "slides", cujos paradeiros são, até hoje, desconhecidos.

Como em outras ocasiões, algemados e encapuzados, os presos foram imediatamente conduzidos à polícia do Exército, ao DOI-CODI, e às torturas. Durante 10 dias, incomunicáveis, padeceram do roteiro sádico, tornado clássico em dez anos de pressão sem inibições: choques elétricos, pau de arara, geladeira, fome, asfixia, humilhações sexuais etc. Mas, desde o primeiro momento, a imprensa "colou" no caso. Inicialmente, "O Estado de S.Paulo", e, depois, esta "Folha de S. Paulo", que passou a noticiar, diariamente, as prisões e as minúcias do tratamento policial. Toda a imprensa abriu espaço para as "torturas do MEP", com repercussão imediata na sociedade, estudantes, Congresso, etc, e no exterior.

Houve requintes. A mãe de Maria Cecília Bárbara Wetten, de 61 anos, e sua irmã Maria Antônia, de 56 anos, foram presas e conduzidas ao DOI-CODI, despidas à força e ameaçadas de choques elétricos para revelarem o paradeiro do Maria Cecília, presa, horas depois, em Rio Claro, São Paulo.

Paralelamente, os familiares dos presos desenvolviam intensa atividade de denúncia e mobilização. À medida que o escândalo crescia, procuraram o cardeal D. Eugênio Sales, que, dessa vez, convenceu-se da sinceridade do horror das 
senhoras. D. Eugênio entrou em contato com o comandante do $1^{\circ}$ Exército, general José Pinto de Araújo Rabelo, que garantiu a integridade dos presos. Dias depois, as denúncias continuando, o cardeal insistia e revelava a disposição de recusar-se a rezar a missa do Dia do Soldado (25 de agosto) se as torturas não parassem. No dia 5 de agosto, em manchete de primeira página. (10 Exército vai apurar torturas") a "Folha" noticiava esse contato e a promessa do general.

A nota oficial do comando, entretanto, como de hábito, negava veracidade às denúncias. As denúncias de tortura eram tentativas de envolver os órgãos de segurança do $1^{\circ}$ Exército com o "nítido propósito de tumultuar e confundir a opinião pública". O $1^{\circ}$ Exército assegurava que tomara conhecimento de todas as peças do inquérito, "inclusive" os autos do exame de corpo de delito, passados pelo Instituto Médico Legal, os quais registraram o bom estado físico e mental dos detidos". Apenas o exame fora feito com os presos já removidos para o DPPS, dez das depois da incomunicabilidade no DOI-CODI, prazo suficiente para que as mais selvagens torturas perdessem a nitidez das suas marcas.

Os depoimentos prestados na fase do IPM, nos 55 dias passados no DPPS, foram conseguidos sob constante ameaça de volta às torturas no DOI-CODI, concretizados: quatro pessoas foram removidas, o que levou o restante dos presos a realizar uma greve de fome pela volta dos companheiros e pela garantia de não haver mais remoções.

No dia 27 de outubro, na $1^{\text {a }}$ Auditoria da Aeronáutica, começou a tomada dos depoimentos. Os testemunhos foram noticiados por todos os jornais, na íntegra, com fotos e chamadas de primeira página, numa cobertura inédita nos últimos 10 anos. As torturas sofridas nos dez dias de incomunicabilidade passaram ao conhecimento de todos. Em meio a uma segunda greve de fome dos presos políticos do Estado, por melhores condições carcerárias, as preventivas foram relaxadas e todos os depoentes soltos. Pela medida, o irritável promotor Gastão dos Santos Ribeiro acusou o juiz Teócrito Rodrigues de Miranda de "excessivamente liberal". 
As denúncias dos presos foram amplamente comentadas no Congresso. $\mathrm{O}$ assessor de imprensa da presidência da República, coronel Toledo Camargo, as classificou de "impressionantes e sérias". Durante os depoimentos, o delegado Nahil Jorde Hauat, chefe da divisão de Operações Especiais da DPPS, admitiu, sob cerrado interrogatório dos advogados de defesa, que realizara buscas sem mandado, assinara auto de apreensão sem conferir e que apresentara, por ofícios, presos que não havia prendido. Não sabia quem prender. Mais maquiavélico ainda foi o escrivão Jorge Segretto Filho, que descreveu com detalhes cenas de acareação entre os acusados. Aparentemente, a testemunha da promotoria não sabia que houve sequer uma acareação em todo o processo do MEP".

\subsection{A anistia}

A partir do 08 de janeiro de 1979, o STM voltava a julgar os habeas corpus, sob a presidência interina do ministro Jacy Guimarães Pinheiro. Na fila, encontravam-se Hcs em favor de Brizola, do estudante Edval Nunes da Silva, o "Cajá", e dos membros do MEP ${ }^{202}$. No dia 10, o procurador Gastão dos Santos recorreu contra a absolvição dos sete inocentados ${ }^{203}$. Outro procurador militar, Paulo Duarte, apresenta parecer contrário aos Hcs da defesa, alegando para tanto a agitação promovida pelos presos no dia da audiência condenatória, o que os colava na condição de não exercerem bom comportamento ${ }^{204}$. O presidente do STM, Almirante Hélio Leite, nega os pedidos de soltura ${ }^{205}$, no fim de janeiro.

Finalmente, no dia 12 de fevereiro, por sete votos a seis, o Supremo Tribunal Militar concede o Habeas Corpus coletivo ${ }^{206}$. Sidney Lianza, Arthur Obino Neto, Ignácio Guaraci, Luiz Arnaldo Dias Campos, condenados a dois anos, e Franklin

202 O Globo, 07 de janeiro de 1979.

203 O Globo, 10 de janeiro de 1979.

204 O Globo, 24 de janeiro de 1979.

205 O Globo, 30 de janeiro de 1979.

206 Folha de São Paulo, 13 de fevereiro de 1979. 
Coelho, Ivan Valente, Frederico José Falcão, André Teixeira Moreira, Jorge José de Melo e Cláudio Rocha Roquete, condenados a três anos, deixam a Divisão de Segurança Nacional, na rua Frei Caneca, às 23 horas e 45 minutos, sob aplausos de um grupo.

A máquina repressiva da ditadura, no entanto, não se dava por vencida. Novo inquérito sobre o MEP volta para o DPPS, sob o comando do delegado José Carlos Nunes. O Ministério Público Militar pediu a abertura de outra investigação, após o aparecimento dos seguintes nomes: Paulo Maurício Campanha Lourenço, Luisa Maria Santana Spinetti, André Luis Pappi, Márcio Miranda Ferreira, Luis Carlos Azevedo Cruz, Vera Lúcia Colson, Luis Cesar da Costa, Luis Antônio Correia de Carvalho e Luis Felipe Falcão.

O novo inquérito não foi para frente. Os ventos da liberdade começaram a soprar após o fim da vigência do Al-5, em 31 de dezembro de 1978. Com a Lei de Anistia, de 28 de agosto, todos os apelantes foram considerados anistiados ${ }^{207}$.

O MEP entendia a prisão como um campo da luta de classes. Aos militantes presos, cabia a responsabilidade de não abrir informações que comprometessem a existência da organização. O grupo, mesmo com o ataque feroz da ditadura, não foi desbaratado. É possível dizer, por mais que pareça paradoxal, que saiu fortalecido. As ações de denúncia contra o regime militar continuaram mesmo durante o processo das prisões. O MEP, de um pequeno grupo nascido praticamente de estudantes vindos da POLOP, ganhou dimensão nacional. Ao manter seu funcionamento ativo, o ataque ao MEP, na verdade, virou contra o próprio regime. As denúncias das torturas, das arbitrariedades jurídicas, das fraudes processuais ficaram evidentes. A linha dura do Exército queria liquidar a nova organização. É fato que isso resultava da quebra de braço no interior do próprio regime. Por outro lado, a máquina repressiva tinha o intuito de assustar o conjunto das forças políticas que lutavam por democracia. E mais, agiam de maneira "profilática", de modo a atacar pilares da possível construção de outro projeto político. Essa batalha a ditadura 207 Fragoso, Cláudio Heleno. Advocacia da liberdade. Editora Forense. Rio de Janeiro, 1985. Pg. 174. 
militar perdeu. O MEP sobreviveu e ganhou a narrativa na sociedade. Como um campo da luta de classes, a resistência do Movimento pela Emancipação do Proletariado às prisões foi o maior golpe que o grupo desferiu contra o governo autoritário dos coturnos. 


\section{CRESCIMENTO, NACIONALIZAÇÃO E CHEGADA DO PT}

A repressão ao MEP exerceu efeito ambíguo. Ao mesmo tempo em que quase desbaratou a organização, fez com que a projeção do grupo alcançasse dimensões jamais vistas. Durante as prisões, o maior desafio passou a ser a própria existência, sobretudo no Rio de Janeiro, onde o mapeamento feito pelos órgãos de inteligência da ditadura foi muito aprofundado. Sem embargo, o MEP não paralisou as suas atividades, mesmo diante dos momentos mais tensos.

Em São Paulo, o militante operário Miguel Carvalho ${ }^{208}$, atuante na região do Jardim Miriam, zona sul da capital paulista, comenta que seu ingresso no MEP se deu através da campanha pela libertação dos presos políticos, que ocorria paralelamente ao movimento contra a carestia. A agitação em torno da soltura dos presos ocorria nas universidades, nas oposições sindicais, no Comitê Brasileiro pela Anistia/SP, enfim, o MEP paulista defendia essa bandeira em todos os locais em que estava presente.

Já no Rio de Janeiro, ainda que o cenário fosse, por óbvio, mais conturbado, a prática do grupo não cessou. Isso pode ser acompanhado através da continuidade da produção e circulação do jornal Nova Luta. No auge das quedas, foi editado o número 21 do jornal, em agosto de $1977^{209}$. O periódico já estava pronto para ser rodado na gráfica, quando as prisões foram anunciadas. Rapidamente, houve um trabalho de alteração do número, para dar sentido à inesperada situação.

O No 21 do NL começa uma nota explicativa, que será abaixo reproduzida:

"A publicação deste número de Nova Luta no interior (assim como a republicação no exterior), alguns dias após a ofensiva repressiva sobre nossa Organização, é uma vitória para nós e para o conjunto do movimento revolucionário. Uma vitória que só foi possível pela solidariedade política e financeira encontrada em parcelas importantes do movimento de massas (que se mobilizaram pelos companheiros presos e dificultaram a ofensiva da repressão), pela solidariedade eficiente de Organizações Revolucionárias Irmãs e pela própria capacidade de nossa Organização em defender-se da repressão.

Ao publicarmos este número, pretendemos mostrar a nossa disposição de continuar a luta e de resistir a próximas ofensivas que temos certeza deverão vir. Ao buscarmos a solidariedade

208 Entrevista concedida por Miguel Carvalho, em 02 de abril de 2019.

209 Nova Luta, № 21, agosto de 1977. 
do movimento de massas e no conjunto do movimento revolucionário, buscarmos o reforço necessário para enfrentar estas ondas repressivas, apenas materializamos mais uma vez dois elementos de nossas definições: 1 - O fato de não termos ilusões em aberturas vindas de setores burgueses e de que portanto devemos confiar a defesa de nossa luta ao movimento de massas dos trabalhadores e oprimidos; 2 - A compreensão de que somos apenas um dos destacamentos avançados do proletariado e parte do movimento revolucionário que, para se defender, necessita defender cada um de seus destacamentos.

As inúmeras tarefas que se colocaram para a Organização neste período fizeram porém que este número de nosso jornal não saísse como habitualmente. Este número já estava na gráfica quando se verificou a onda repressiva. Após, ele foi retirado e modificado em função da nova situação, tendo sido integrado ou modificado artigos e retirada toda a parte relativa a lutas e denúncias, com o objetivo de reduzir o volume do jornal.

No exterior, no entanto, a pedido dos camaradas do Brasil, agregamos todas as partes que haviam sido cortadas. Como as maquetes ainda não estavam completas, em algumas maquetes e mesmo na capa original não aparecem algumas fotos que estavam programadas, mas ainda não estavam coladas nas maquetes. Aqui no exterior, o leitor poderá ter acesso deste material em primeira mão, na segunda parte desta edição.

Por último, seja pelo volume que ele adquiriu, seja pelas condições em que é publicado será cobrado 10 francos por este número e solicitamos ainda 20 francos ou uma contribuição superior como pagamento solidário. Esta será uma importante solidariedade e apoio aos camaradas que no interior buscam cobrir as brechas criadas pela ofensiva repressiva. Seção exterior do MEP - Movimento pela Emancipação do Proletariado ${ }^{210 " . ~}$

Nessa mesma edição, discutem a questão do arrocho, da carestia e do desemprego. Fazem uma análise da prisão de seus militantes, localizando-as no contexto em que a ditadura se esforçava para combater toda a esquerda. Afirmam que "a resistência à política repressiva da ditadura não se reduz à defesa de uma determinada organização. A ação da polícia política visa liquidar toda a esquerda para conter o avanço das lutas das massas oprimidas e das manifestações de resistência à ditadura". ${ }^{211}$ Há, por fim, um documento de maior fôlego, que busca localizar a crise política, as tendências políticas no movimento de massas, o trabalho de massas e o debate sobre a Constituinte ${ }^{212}$. Em 1978, ainda sob o cerco da repressão, o MEP publica os números 23 e 24 do NL, respectivamente em abril e setembro.

A manutenção da ação prática do MEP, todavia, se deu a duras penas. As frentes

210 Nova Luta, № 21, setembro de 1977.

211 Nova Luta, № 21, de setembro de 1977.

212 Este documento pouco inova em relação às orientações gerais delineadas na Convenção Nacional de 1976. Aspectos novos são abordados quanto ao tema da Constituinte. Este tópico será aprofundado mais à frente. 
foram desmobilizadas por questão de segurança. Ainda no Rio de Janeiro, formouse uma comissão informal composta por três militantes, à qual coube a responsabilidade de rearticulação. Ao Jorge Paz, vindo de São Paulo e radicado no Rio, foi atribuído o movimento operário. À Vera Colson, coube o movimento estudantil. Ambos eram assistidos por Nilson Penoni, membro da direção nacional que não foi preso no momento das quedas ${ }^{213}$.

Com a anistia e a abertura política, O MEP pôde colher os frutos da luta de resistência às prisões. Das principais iniciativas, passado o momento de maior turbulência, encontra-se a criação do jornal Companheiro, que chegou a ter bastante relevância entre as esquerdas e os movimentos dos trabalhadores.

Importante destacar aqui é a evolução da questão democrática para o MEP. Vale a pena transcrever a opinião de Luiz Arnaldo.

A partir de 1976, com o crescimento do movimento antiditadura, a questão das liberdades democráticas assume um papel central na disputa entre as organizações políticas pela direção do movimento. De um lado estava aquilo que o MEP denominava de "o reformismo e o democratismo", encabeçado pelo PCB, PC do B, MR8, que colocava no centro da tática a conquista da democracia burguesa, cuja expressão de maior radicalidade seria a Assembleia Nacional Constituinte. No outro extremo o imobilismo da PO que considerava que qualquer bandeira democrática ajudava a reforçar a hegemonia liberal do movimento. Numa posição - novamente singular- o MEP defendia que as lutas democráticas deviam se dirigir contra os pilares da dominação capitalista - fiel à sua concepção de que a ditadura era a única forma política de manutenção do capitalismo brasileiro. Na prática, isto desembocou numa batalha de palavras de ordem: ampla liberdade partidária $\mathrm{X}$ liberdade para partidos operários e populares. Ou então liberdades democráticas $X$ liberdade de manifestação e organização para os trabalhadores e setores oprimidos. Para o MEP, suas palavras de ordem eram uma maneira de disputar para o campo operário e popular a hegemonia do movimento antiditatorial, fortalecendo uma alternativa à crise da ditadura que fosse além dos marcos da democracia burguesa. Estas posições foram consolidadas na edição número 4 da revista Teoria e Prática, intitulada "Sobre o Democratismo e as Liberdades Democráticas". Esta disputa teve uma importância muito grande neste período.

Outro aspecto foi a participação decidida do MEP no movimento pela Anistia Ampla, Geral e Irrestrita, principalmente no interior do Comité Brasileiro pela Anistia - organização dirigente da luta -, particularmente no Rio e São Paulo, com destaque para militantes como Iná Meireles, Sidney Lianza e Ivan Valente, entre muitos outros. Nesta luta, o MEP, juntamente com diversos outros setores, conseguiu afirmar o conceito de que a luta pela Anistia era indissociável da exigência do fim do aparelho repressivo e do julgamento dos torturadores.

Na trajetória do MEP é também digno de menção o giro ocorrido em 1978, quando a Organização, pela

213 Quem nos explicou esse momento de rearticulação foi Vera Colson, em entrevista realizada em 03 de abril de 2019. 
primeira vez, decide participar das eleições parlamentares apoiando candidatos do MDB que se comprometessem com sua plataforma de lutas para o período. No Rio, foram apoiados José Eudes (militante da APML) a deputado estadual e Paulo Faria (independente) a deputado federal. Em São Paulo, Geraldo ( militante da APML) a deputado estadual. Na Bahia, a organização também apoiou um candidato a deputado estadual. Eudes e Geraldinho foram eleitos e cumpriram mandatos combativos de luta contra a ditadura. $\mathrm{Na}$ época a direção da organização publicou um texto (apesar de todos os problemas com as quedas recentes) onde preconizava que o crescimento da luta antiditadura e a consequente abertura de espaços para a luta política permitia e justificava o apoio a candidatos comprometidos com um programa de luta radical contra a ditadura, em defesa da organização dos trabalhadores e do socialismo ${ }^{214}$.

\subsection{A volta do movimento operário}

Depois de dez anos das grandes greves de 1968, que tiveram maior impacto em Osasco e Contagem, o movimento operário volta a surgir, abrindo uma nova janela na história do movimento dos trabalhadores. Em meados dos anos 1970, as oposições sindicais tentavam mobilizar as bases, na contramão da ditadura e da estrutura sindical controlada por pelegos. Pequenas mobilizações nunca deixaram de ocorrer, como bem retrata o jornal Nova Luta, todavia essas eram dispersas e seus atores contavam com pouco elaboração em nível de consciência política. Anos de arrocho salarial, aumento do custo de vida e repressão criavam um caldeirão de pólvora. $\mathrm{O}$ abrandamento da censura à imprensa permitiu a veiculação de matérias que denunciavam a manipulação em índices de inflação e na correção salarial. Esta parece ter sido a senha que fez explodir uma greve espontânea na Scania, em 12 de maio de 1978, em São Bernardo do Campo. Os operários resolveram cruzar os braços em frente às máquinas. A mobilização seguiu como rastilho, envolvendo outras fábricas. A figura de Luiz Inácio Lula da Silva apareceu neste momento no cenário nacional. No ano seguinte, nova greve. Dessa vez, mais preparada pelo Sindicato dos Metalúrgicos do ABC. A mobilização grevista começou em 13 de maio de 1979. Os operários desafiaram as leis da ditadura para empenhar seu movimento. Houve repressão e intervenção no sindicato. Reuniões e assembleias ocorriam dentro da Igreja e na Praça Matriz de São Bernardo. A justeza das reivindicações, centradas no reajuste salarial, logo conquistou apoio de amplas parcelas da opinião pública, intelectuais, estudantes, mobilizando o conjunto das

214 Contribuição enviada por escrito por Luiz Arnaldo, em 05 de maio de 2019. 
forças democráticas ${ }^{215}$.

Não só no ABC havia agito operário. Em 1978, os metalúrgicos de São Paulo também pararam, à revelia do sindicato, então comandado pelo Joaquinzão. Em 1979, a oposição metalúrgica na cidade de São Paulo - composta por organizações clandestinas, lideranças independentes e fortemente alicerçada nas bases da igreja católica - conseguiu organizar uma grande paralisação. O comando de greve suplantou a direção do sindicato e chegou a criar cinco subsedes nos bairros para articular melhor as reivindicações ${ }^{216}$. Foi no contexto dessa luta que tombou com um tiro no peito o operário Santo Dias, fato que aumentou ainda a mobilização.

Já em 1980, nova greve geral dos metalúrgicos ocorreu, tendo São Bernardo como epicentro. Durou 41 dias, com direito a prisões das lideranças, Lula incluso, novas intervenções no sindicato, repressão nas ruas e assembleias históricas na Vila Euclides ${ }^{217}$. Embora as demandas não tenham sido atendidas, o saldo político desses anos de luta operária era inegável. Consolidava-se ali o chamado sindicalismo autêntico. Surgia dessas experiências a compreensão da necessidade de se formar um partido dos trabalhadores, capaz de levar para a esfera política as pautas econômicas. Ainda que toda essa explosão tenha tido o $A B C$ Paulista como centro, lutas operárias pipocavam em todo o país.

O MEP esteve presente nesse momento de efervescência, saudando os grevistas com entusiasmo. A perspectiva de retomada das lutas operárias era esperada desde o surgimento do grupo. Para uma organização que compreendia que o processo de transformação derivava justamente da participação política da classe trabalhadora, a entrada em cena desses atores acendia a expectativa da mudança. O MEP desenvolvia uma política de incentivo das oposições sindicais. Conseguiu algum retorno, sobretudo, em Osasco, São Paulo, Rio de Janeiro e Niterói. Apostava também na construção de comitês da fábrica e círculos operários,

215 Frederico, Celso. A esquerda e o movimento operário (196401984) - a reconstrução. Vol. 3. Editora Oficina de Livros. Belo Horizonte, 1991. Pg. 14.

216 Idem. Pg. 20.

217 Ibidem. Pg. 17. 
espaços dedicados à formação de militantes, que deveriam atuar no sindicato mesmo este estando atrelado ao Ministério do Trabalho e amarrado pelas direções pelegas. Sem embargo, sempre houve empenho no sentido de construir uma intervenção junto ao proletariado.

Em São Paulo, Miguel Carvalho comenta que o trabalho do MEP na oposição metalúrgica começou em meados de 1977. A organização participou da greve de 1978. Nessa época, existiam algumas células operárias. Na zona sul de São Paulo, era composta por Lurdinha, Almeidinha, pelo próprio Miguel e outros militantes. A assistente era Maria, militante vinda do Rio de Janeiro após as prisões. Havia também em Osasco, onde se destacavam Waldir e Manetão. Por Guarulhos, o dirigente era o Albertão. Posteriormente, o MEP veio a ter alguma entrada no ABC. A organização ajudou a chapa da oposição metalúrgica em São Paulo, em 1979, e participou efetivamente da disputa de 1981, quando a chapa da oposição era encabeçada por Waldemar Rossi. Miguel compôs a chapa pelo MEP.

No Rio de Janeiro, o grupo tinha atuação na oposição metalúrgica na própria capital e presença de destaque entre os metalúrgicos de Niterói. Nessa cidade, o MEP dirigiu a primeira grande greve operária no Estado do Rio de Janeiro desde 1964, ocorrida em 1979. Ainda neste ano, participou da eleição vitoriosa do sindicato dos metalúrgicos, constituindo uma das primeiras diretorias combativas do estado. Mais tarde, o MEP teve assento na diretoria do sindicato dos metalúrgicos de Volta Redonda, atuando em novas greves ${ }^{218}$.

Em Minas Gerais e Pernambuco houve alguma influência ${ }^{219}$. No estado nordestino em questão, o MEP atuou na oposição Metalúrgica de Recife, cuja liderança João Paulo foi posteriormente eleito prefeito da capital pelo PT. Nacionalmente, o MEP chegou a se envolver no Encontro Nacional de Trabalhadores em Oposição à Estrutura Sindical (ENTOES), ocorrido em setembro de 1980, sem grandes retornos.

Um interessante trabalho coletivo, resultado da disciplina "Economia Política e

218 Contribuição enviada por escrito por Luiz Arnaldo, em 05 de maio de 2019. 219 Entrevista concedida por Miguel Carvalho em 02/04/2019. 
Vida Política", do curso de Ciências Sociais da USP, no $2^{\circ}$ semestre de $1981^{220}$, analisa diversas posições a respeito das polêmicas do mundo sindical, a partir da leitura dos periódicos de algumas organizações políticas, dentre as quais o MEP com seu jornal Companheiro. Vale aqui pontuar algumas opiniões. Em relação à unicidade e ao pluralismo sindical, defende que o pluralismo, embora apareça como algo democrático, serve à divisão do movimento. Considera que a unicidade sindical, como pode ser sintetizada com a criação da CUT, é a que deve ser encarada pelo sindicalismo autêntico ${ }^{221}$. Quanto à contribuição sindical, se posiciona contrariamente pontuando a independência frente ao Estado, embora defenda a permanência pontual enquanto o movimento não se estrutura de maneira adequada ${ }^{222}$. A respeito da avaliação do movimento sindical, afirma que este possui duas tendências: pelegos e autênticos. Enquanto os primeiros defendem os interesses dos patrões e do Estado, os segundos avançam em defesa dos direitos dos trabalhadores ${ }^{223}$. A respeito da CUT, defende a sua criação em 1982 e a formação de uma comissão pró-CUT. Alinha-se à "CUT pela base" 224 . Sobre as formas de luta, afirma que a greve geral é a principal arma do movimento sindical ${ }^{225}$. Quando o assunto é a Assembleia Geral Constituinte, não há posição clara ${ }^{226}$. Defende a reforma agrária radical, a expropriação de terras e ocupação por posseiros e favelados ${ }^{227}$. Considera que a Conferência Nacional da Classe Trabalhadora (CONCLAT), ocorrida em agosto de 1981, foi um sucesso, pois serviu para organizar as lutas sindicais e por conferir aos trabalhadores a noção de que estavam sendo protagonistas de um fato histórico 228 .

220 Araújo, Braz José. A imprensa alternativa e a Conclat. In: Frederico, Celso. A esquerda e o movimento operário (196401984) - a reconstrução. Vol. 3. Editora Oficina de Livros. Belo Horizonte, 1991. Pg. 259

221 Idem. Pg. 267.

222 Ibidem. Pg. 274.

223 lbidem. Pg. 280.

224 Ibidem. Pg. 288.

225 Ibidem. Pg. 295.

226 Ibidem. Pg. 299.

227 Ibidem. Pg. 303.

228 Ibidem.. Pg. 311. 


\subsection{O PT entra em cena}

Desde que começou a ser ventilada a ideia de construção de um partido dos trabalhadores, a partir das greves operárias de 1978 no ABC paulista, o MEP a viu com bons olhos. Este grupo carregava consigo, desde a OCML-POLOP, a compreensão da necessidade de construir um partido socialista, de vanguarda, que representasse e fosse composto pelas consciências mais avançadas do proletariado. Tal modelo de raciocínio reproduzia a noção leninista de partido. Os primeiros movimentos de construção do PT indicavam que não era exatamente o que MEP esperava, no entanto, havia algo inquestionável: o Partido dos Trabalhadores nascia das greves operárias e das lutas dos trabalhadores, sendo que o aspecto econômico sublevou o político, fazendo com que a elevação da consciência traduzisse a necessidade de construir um partido da classe trabalhadora.

A efervescência política dava a tônica no fim dos anos 70. $O$ movimento estudantil reanimava-se. As greves aumentavam. A paralisação na Scania, em São Bernardo, em 1978 arrastou 150 mil trabalhadores insatisfeitos com o salário ${ }^{229}$. Em 1979, greve geral dos metalúrgicos de São Paulo ${ }^{230}$. A luta contra a carestia e a politização das Comunidades Eclesiais de Base (CEBs) se disseminavam nas cidades. Toda essa sinergia política deu empuxo à criação do PT. Desde o início, o MEP estava dentro desse processo.

No $1^{\circ}$ de maio de 1979, Paulo Skromov, Jacó Bittar, Henos Amorina, Wagner Benevides e Robson Camargo, que compunham a Comissão Nacional Provisória do movimento pró-PT, assinam a Carta de Princípios do Partido dos Trabalhadores ${ }^{231}$. O documento é revelador do espírito da época. Vale conferir a íntegra:.

229 Secco, Lincoln. História do PT. Editora Ateliê Editorial. São Paulo, 2011. Pg. 38.

230 Frederico, Celso. A esquerda e o movimento operário (1964-1984). Volume 3. Editora Oficina de Livros. Belo Horizonte, 1991. Pg. 111.

231 Secco, Lincoln. História do PT. Editora Ateliê Editorial. São Paulo, 2011. Pg. 41. 
"A idéia da formação de um partido só dos trabalhadores é tão antiga quanto a própria classe trabalhadora.

Numa sociedade como a nossa, baseada na exploração e na desigualdade entre as classes, os explorados e oprimidos têm permanente necessidade de se manter organizados à parte, para que Ihes seja possível oferecer resistência séria à desenfreada sede de opressão e de privilégios das classes dominantes.

Mas sempre que as lideranças dos trabalhadores e oprimidos se lançam à tarefa de construir essa organização independente de sua classe, toda sorte de obstáculos se contrapõe a seus esforços.

Essa situação vivida milhares de vezes em todos os países do mundo vem acontecendo agora no Brasil. Começando a sacudir o pesado jugo a que sempre estiveram submetidos, os trabalhadores de nosso país deram início, em 12 de maio do ano passado (greve da Scania), a sua luta emancipadora. Desde então, o operariado e os setores proletarizados de nossa população vêm desenvolvendo uma verdadeira avalanche pela melhoria de suas condições de vida e de trabalho. A experiência dessas lutas tem como resultado um visível amadurecimento político da população trabalhadora e o crescimento, em quantidade e qualidade, de suas lideranças.

Esse rápido amadurecimento político pode ser visto claramente no aprimoramento das formas de luta de que os trabalhadores têm lançado mão. O início das lutas é marcado por um período de greves brancas nas fábricas. Já os embates mais recentes, dos quais a greve geral metalúrgica do $A B C D$ é o melhor exemplo, mostram a retomada, em toda a linha, das formas clássicas de luta: grandiosidade das assembléias gerais, a ação decisiva dos piquetes e dos fundos de greve.

Os trabalhadores entenderam ao longo desse ano de lutas que suas reivindicações mais sentidas esbarravam em obstáculos cada vez maiores, e é por isso, dialeticamente, que vão sendo obrigados a construir organizações cada vez mais bem articuladas $e$ eficazes. Diante da força da greve do $A B C D$, os patrões e o governo precisaram dar-se as mãos para impedir o fim da política do arrocho salarial e o fim das estruturas semifascistas que tangem nossos sindicatos. Os patrões usam de todos os meios a seu alcance para quebrar a unidade dos trabalhadores, ao mesmo tempo em que se recusam a reconhecer os acordos obtidos no período das greves fabris. O governo desencadeia sua repressão: os sindicatos são invadidos e suas direções destituídas oficialmente, enquanto nas ruas a polícia persegue os piquetes e tenta impedir, pela violência, que os trabalhadores consigam local para se reunir.

Por seu lado, o apoio que os metalúrgicos conseguem dos demais trabalhadores, embora seja suficiente para impedir que a repressão se aprofunde e faça produzir um recuo parcial, carece de maior conseqüência, devido, é claro, não à inexistência de um espírito de solidariedade, mas sim devido às limitações do movimento sindical e à inexistência de sua organização política. Tanto isso é verdade que as lideranças da greve são obrigadas a se escorar no apoio, muitas vezes duvidoso, de aliados ocasionais, saídos do campo das classes médias e da própria burguesia.

Não puderam os trabalhadores expressar de modo mais conseqüente todo o seu apoio aos grevistas do $A B C D$, e essa impotência tenderá a continuar enquanto eles mesmos não se organizarem politicamente em seu próprio partido.

É por isso que a idéia de um partido dos trabalhadores, ressurgindo no bojo das greves do ano passado e anunciado na reunião intersindical de Porto Alegre, em 19 de janeiro de 1979, tende a ganhar, hoje, uma irresistível popularidade. Porque se trata, hoje, mais do que nunca, de uma necessidade objetiva para os trabalhadores. 
Cientes disso também é que setores das classes dominantes se apressam a sair a campo com suas propostas de PTB. Mas essas propostas demagógicas já não conseguem iludir os trabalhadores, que, nem de longe, se sensibilizaram com elas. Esse fato comprova que os trabalhadores brasileiros estão cansados das velhas fórmulas políticas elaboradas para eles. Agora, chegou a vez de o trabalhador formular e construir ele próprio seu país e seu futuro. Nós, dirigentes sindicais, não pretendemos ser donos do PT, mesmo porque acreditamos sinceramente existir, entre os trabalhadores, militantes de base mais capacitados e devotados, a quem caberá a tarefa de construir e liderar nosso partido. Estamos apenas procurando usar nossa autoridade moral e política para tentar abrir um caminho próprio para o conjunto dos trabalhadores. Temos a consciência de que, nesse papel, neste momento, somos insubstituíveis, e somente em vista disso é que nós reivindicamos o papel de lançadores do PT.

O povo brasileiro está pobre, doente e nunca chegou a ter acesso às decisões sobre os rumos do país. E não acreditamos que esse povo venha a conhecer justiça e democracia semo concurso decisivo e organizado dos trabalhadores, que são as verdadeiras classes produtoras do país.

É por isso que não acreditamos que partidos e governos criados e dirigidos pelos patrões e pelas elites políticas, ainda que ostentem fachadas democráticas, possam propiciar 0 acesso às conquistas da civilização e à plena participação política a nosso povo.

Os males profundos que se abatem sobre a sociedade brasileira não poderão ser superados senão por uma participação decisiva dos trabalhadores na vida da Nação. $O$ instrumento capaz de propiciar essa participação é o Partido dos Trabalhadores. Iniciemos, pois, desde já, a cumprir esta tarefa histórica, organizando por toda parte os núcleos elementares desse partido.

1. A sociedade brasileira vive, hoje, uma conjuntura política altamente contraditória e, sob muitos aspectos, decisiva quanto a seu futuro a médio e longo prazos. Vista do ângulo dos interesses das amplas massas exploradas, desde sempre marginalizadas material e politicamente em nosso país e principais vítimas do regime autoritário que vigora desde 1964, a conjuntura revela tendências extremamente promissoras de um futuro de liberdades e de conquistas de melhores condições de vida. Dentre as tendências auspiciosas, destaca-se a emergência de um movimento de trabalhadores que busca afirmar sua autonomia organizatória e política face ao Estado e às elites políticas dominantes. Esse é, sem dúvida alguma, o elemento inovador e mais importante da nova etapa histórica que se inaugura no Brasil, hoje.

Contudo, a par dos dados auspiciosos da conjuntura política, coexistem também perigosos riscos, que podem levar as lutas populares a novas e fragorosas derrotas. Aqui, cabe destacar que o processo chamado de abertura política está sendo promovido pelos mesmos grupos que sustentaram e defenderam o regime hoje em crise. Com a evidente exaustão de amplos setores sociais com o regime vigente no país e com a crise econômica que abalou a estabilidade dos grupos dominantes que controlam o aparelho de Estado, os detentores do poder procuram agora, e até este momento com relativo êxito, reformar o regime de cima para baixo. Vale dizer, pretendem reformar alguns aspectos do regime, mantendo o controle do Estado, a fim de evitar alterações no modelo de desenvolvimento econômico, que só a eles interessa e que se baseia, sobretudo, na superexploração das massas trabalhadoras, através do modelo econômico do qual sobressai o arrocho salarial.

Já está demais evidente que o novo governo militar pretende manter a continuidade dessa mesma política econômica ditada pelo capital financeiro internacional, agravada agora pelos planos de austeridade e recessão que já se esboçam. Isso significa que o sofrimento, a miséria material e a opressão política sobre a população trabalhadora tenderão a se manter e aprofundar. 
O que significa Estado de Direito com salvaguardas? O que pretendem com anistia restrita? O que visam com a propalada reforma da CLT [Consolidação das Leis do Trabalho] e a da Lei de Greve, urdidas secretamente? Qual o sentido da diminuição das penas previstas na Lei de Segurança Nacional e da preservação do espírito que informa essa mesma Lei? Esses e tantos outros fatos indicam que o regime busca reformar-se tentando atrair para seu campo de apoio setores sociais e segmentos políticos oposicionistas, com vista a impedir que as massas exploradas explicitem suas reivindicações econômicas e sociais e, o que é mais importante, sua concepção de democracia.

Em poucas palavras, pretendem promover uma conciliação entre os de cima, incluindo a cúpula do $M D B$, para impedir a expressão política dos de baixo, as massas trabalhadoras do campo e da cidade.

2. Essas afirmações não ignoram o fato de que o MDB foi utilizado pelas massas para manifestar eleitoralmente seu repúdio ao arbítrio. Tampouco pretendem ignorar a existência, entre seus quadros, de políticos honestamente comprometidos com as lutas populares.

Isso, no entanto, não pode impedir e não nos impede de apontar as limitações que o MDB - partido de exclusiva atuação parlamentar - impõe às lutas populares por melhores condições de vida e por um regime democrático de verdadeira participação popular. $O M D B$, por sua origem, por sua ineficácia histórica, pelo caráter de sua direção, por seu programa prócapitalista, mas sobretudo por sua composição social essencialmente contraditória, em que se congregam industriais e operários, fazendeiros e peões, comerciantes e comerciários, enfim, classes sociais cujos interesses são incompatíveis e nas quais, logicamente, prevalecem em toda a linha os interesses dos patrões, jamais poderá ser reformado. A proposta que levantam algumas lideranças populares de "tomar de assalto" o MDB é muito mais que insensata: é fruto de uma velha e trágica ilusão quanto ao caráter democrático de setores de nossas classes dominantes.

Aglomerado de composição altamente heterogênea e sob controle e direção de elites liberais conservadoras, $O M D B$ tem-se revelado, num passado recente, um conduto impróprio para expressão dos reais interesses das massas exploradas brasileiras. Está na memória dos trabalhadores a conduta vacilante de parcelas significativas de seus quadros quando da votação da emenda Accioly, da lei antigreve e de outras medidas de interesse dos trabalhadores.

Apegado a uma crítica formalista e juridicista do regime autoritário, o MDB tem-se revelado impermeável aos temas sociais e políticos que tocam, de fato, nos interesses das massas trabalhadoras.

Amplos setores das elites políticas e intelectuais das camadas médias da população têm afirmado que "não soou a hora" de se dividir a oposição articulada no interior do $M D B$, afirmando que a democracia não foi ainda conquistada.

Rechaçamos com veemência tal argumento. Primeiro, porque em momento algum podemos aceitar a subordinação dos interesses políticos e sociais das massas trabalhadoras a uma direção liberal conservadora, de extração privilegiada economicamente. Segundo, porque não podemos aceitar que a frente das oposições se mantenha à custa do silêncio político da massa trabalhadora, único e verdadeiro sujeito e agente de uma democracia efetiva.

Tampouco consideramos que a existência de partidos políticos populares venha a contribuir para romper uma efetiva frente da luta dos verdadeiros democratas. O PT considera imprescindível que todos os setores sociais e correntes politicas interessados na luta pela democratização do país e na luta contra o domínio do capital monopolista unifiquem sua ação, estabelecendo frentes interpartidárias que objetivem conquistas comuns imediatas 
e envolvam não somente uma ação meramente parlamentar, mas uma verdadeira atividade política que abranja todos os aspectos da vida nacional.

3. O Partido dos Trabalhadores denuncia o modelo econômico vigente, que, tendo transformado o caráter das empresas estatais, construídas pelas lutas populares, utiliza essas empresas e os recursos do Estado, em geral, como molas mestras da acumulação capitalista. O Partido dos Trabalhadores defende a volta das empresas estatais a sua função de atendimento das necessidades populares e o desligamento das empresas estatais do capital monopolista.

O Partido dos Trabalhadores entende que a emancipação dos trabalhadores é obra dos próprios trabalhadores, que sabem que a democracia é participação organizada e consciente e que, como classe explorada, jamais deverão esperar da atuação das elites privilegiadas a solução de seus problemas.

O PT entende também que, se o regime autoritário for substituído por uma democracia formal e parlamentar, fruto de um acordo entre elites dominantes que exclua a participação organizada do povo (como se deu entre 1945 e 1964), tal regime nascerá débil e descomprometido com a resolução dos problemas que afligem nosso povo e de pronto será derrubado e substituído por novas formas autoritárias de dominação - tão comuns na história brasileira. Por isso, o PT proclama que a única força capaz de ser fiadora de uma democracia efetivamente estável é a das massas exploradas do campo e das cidades.

O PT entende, por outro lado, que sua existência responde à necessidade que os trabalhadores sentem de um partido que se construa intimamente ligado com o processo de organização popular, nos locais de trabalho e de moradia. Nesse sentido, o PT proclama que sua participação em eleições e suas atividades parlamentares se subordinarão a seu objetivo maior, que é estimular e aprofundar a organização das massas exploradas. O PT não surge para dividir o movimento sindical, muito ao contrário, surge exatamente para oferecer aos trabalhadores uma expressão política unitária e independente na sociedade. E é nessa medida que o PT se tornará, inevitavelmente, um instrumento decisivo para os trabalhadores na luta efetiva pela liberdade sindical.

O PT proclama também que sua luta pela efetiva autonomia e independência sindical, reivindicação básica dos trabalhadores, é parte integrante da luta pela independência política desses mesmos trabalhadores. Afirma, outrossim, que buscará apoderar-se do poder político e implantar o governo dos trabalhadores, baseado nos órgãos de representação criados pelas próprias massas trabalhadoras com vista a uma primordial democracia direta. Ao anunciar que seu objetivo é organizar politicamente os trabalhadores urbanos e os trabalhadores rurais, o PT se declara aberto à participação de todas as camadas assalariadas do país.

Repudiando toda forma de manipulação política das massas exploradas, incluindo, sobretudo as manipulações próprias do regime pré-64, o PT recusa-se a aceitar em seu interior, representantes das classes exploradoras. Vale dizer, o Partido dos Trabalhadores é um partido sem patrões!

As tentativas de reviver o velho PTB de Vargas, ainda que, hoje, sejam anunciadas "sem erros do passado" ou "de baixo para cima", não passam de propostas de arregimentação dos trabalhadores para defesa de interesses de setores do empresariado nacional. Se o empresariado nacional quer construir seu próprio partido político, apelando para sua própria clientela, nada temos a opor, porém denunciamos suas tentativas de iludir os trabalhadores brasileiros com seus rótulos e apelos demagógicos e de querer transformá-los em massa de manobra para seus objetivos. 
O PT não pretende criar um organismo político qualquer. $O$ Partido dos Trabalhadores define-se, programaticamente, como um partido que tem como objetivo acabar com a relação de exploração do homem pelo homem.

O PT define-se também como partido das massas populares, unindo-se ao lado dos operários, vanguarda de toda a população explorada, todos os outros trabalhadores - bancários, professores, funcionários públicos, comerciários, bóia-frias, profissionais liberais, estudantes etc. - que lutam por melhores condições de vida, por efetivas liberdades democráticas e por participação política.

O PT afirma seu compromisso com a democracia plena, exercida diretamente pelas massas, pois não há socialismo sem democracia nem democracia sem socialismo. Um partido que almeja uma sociedade socialista e democrática tem de ser, ele próprio, democrático nas relações que se estabelecem em seu interior. Assim, o PT se constituirá respeitando o direito das minorias de expressar seus pontos de vista. Respeitará o direito à fração e às tendências, ressalvando apenas que as inscrições serão individuais.

Como organização política que visa elevar o grau de mobilização, organização e consciência de massas, que busca o fortalecimento e a independência política e ideológica dos setores populares, em especial dos trabalhadores, o PT irá promover amplo debate de suas teses e propostas de forma a que se integrem nas discussões:

- lideranças populares, mesmo que não pertençam ao partido;

- todos os militantes, trazendo, inclusive, para o interior do debate partidário proposições de quaisquer setores organizados da sociedade e que se considerem relevantes com base nos objetivos do PT.

O PT declara-se comprometido e empenhado na tarefa de colocar os interesses populares na cena política e de superar a atomização e dispersão das correntes classistas e dos movimentos sociais. Para esse fim, o Partido dos Trabalhadores pretende implantar seus núcleos de militantes em todos os locais de trabalho, em sindicatos, bairros, municípios e regiões.

O PT manifesta alto e bom som sua intensa solidariedade com todas as massas oprimidas do mundo".

No dia 13 de outubro de 1979, em São Bernardo, foi lançado oficialmente o movimento pró-PT, momento em que aprovaram normas de funcionamento do movimento, uma declaração política e a Carta de Princípios. Surge outra Comissão Nacional Provisória, mais ampla, composta por Arnóbio Silva, Carlos Borges, Édson Khair, Firmo de Andrade, Francisco Auto, Godofredo Pinto, Henos Amorina, Ignácio Hernandez, Jacó Bittar (coordenador), José Ibrahim, Luiz Inácio da Silva, Luiz Dulce, Manoel da Conceição, Olívio Dutra, Sidney Lianza e Wagner Benevides ${ }^{232}$. Representavam, nessa Comissão, o Movimento pela Emancipação do Proletariado os dirigentes Luiz Dulce e Sidney Lianza.

232 Secco, Lincoln. História do PT. Editora Ateliê Editorial. São Paulo, 2011. Pgs. 42-43. 
No contexto da fundação oficial do PT, dada no dia 10 de fevereiro de 1980, no Colégio Sion, o MEP sintetiza a sua visão desse processo em um documento público, editado no jornal Nova Luta ${ }^{233}$. Com o título "Avaliação e perspectiva em relação ao PT", começam por explicar o novo regime político e social que se desenha com o movimento de redemocratização do país. O fim da ditadura militar apontava a construção de uma sociedade mais aberta, embora a dinâmica de exploração das massas pobres fosse mantida. O PT, nesse contexto, sofria pressões que vinham de diferentes lados. O partido congregava amplos setores sociais em luta, o que o tornava um grande centro de efervescência. Por outro lado, existiam vetores que atuavam no sentido de enquadramento do PT nesse novo regime social que surgia. As alas revolucionárias do partido sofriam diversos ataques, pois a sua política distanciava o Partido dos Trabalhadores da consolidação da democracia burguesa que emergia. Esses ataques vinham, por exemplo, de organizações consideradas reformistas, como o PC e o MR-8. Partiam também de sociólogos de inspiração social-democrata ligados ao Cebrap.

O MEP dizia que a Executiva Nacional Provisória era suscetível a esses ataques, algo que ficou expresso com a edição do Manifesto, considerado um giro à direita por não citar a perspectiva socialista ${ }^{234}$. Lula, por seu turno, com frequência se referia à ala revolucionária do PT por "grupelhos". O Manifesto abria portas para que o PT fosse um instrumento do parlamento burguês.

Outra crítica apontada tinha a ver com o funcionamento partidário. A democracia vinda das bases começou a ser afetada por práticas entendidas como "cupulistas", em que caciques faziam acordões a partir das suas próprias orientações. Critérios pouco claros começaram a ser usados para alçar figuras a posições de mando, como a noção de "representatividade nacional", que poderia ser manipulada com facilidade.

233 Jornal Nova Luta, N²5, fevereiro de 1980.

234 Secco, Lincoln. História do PT. Editora Ateliê Editorial. São Paulo, 2011. Pg. 35. 
No entanto, cabia entender a dinâmica do PT e evitar posturas movidas pela "emoção". O Partido dos Trabalhadores era o desaguadouro de toda uma insatisfação popular com a ditadura e a exploração. Vastos contingentes sociais passavam a passos largos a se identificar com o partido. Tanto setores da classe trabalhadora, quanto outros social-democratas e mesmo políticos pequenoburgueses. Desse modo, era fundamental ter claro como se desenvolvia aquele processo profundamente rico e plural. Nesse sentido, o MEP apoiava o aprofundamento da nova experiência. Considerava fundamental a legalização do PT, e muito se dedicou para tanto nos diversos estados em que atuava. Via com bons olhos a direção política exercida pelo grupo sindicalista autônomo, com Lula à frente, por ter legitimidade na classe operária e por incentivar a organização dos trabalhadores.

O MEP, dessa forma, buscava desenvolver uma política de criação de um polo revolucionário, capaz de disputar a linha do $\mathrm{PT}$ em direção contrária à ditadura e anticapitalista.

Sem embargo, no documento em questão, há a preocupação de que o PT se desvie de seu rumo popular inicial e trilhe no sentido de se tornar um partido "parlamentarista", ou seja, que se articula em função do parlamento. Ao MEP e às outras forças revolucionárias estava posta a tarefa de impedir isso.

Apesar da ressalva, o Movimento pela Emancipação do Proletariado via o PT com grande entusiasmo, posto que o partido agia como uma grande frente política, dado o movimento intenso que existia em torno da sua criação e consolidação.

Vera Colson ${ }^{235}$ comenta dos périplos na zona sul de São Paulo, ao lado de Miguel Carvalho, em busca de assinaturas para legalizar o PT. A abordagem, "assine para legalizar o partido do Lula". As adesões eram imediatas. Ivan Valente ${ }^{236}$, explicando como funcionava o exercício de legalização, brincava ao dizer que em São Caetano do Sul avenidas inteiras eram filiadas, uma vez que o trabalho de 235 Entrevista concedida em 03 de abril de 2019. 236 Entrevista concedida em 06 de abril de 2019. 
conversa se dava de porta em porta. Jorge Paz, presente no Rio de Janeiro nesse momento, em nome do MEP, fazia um caminho que passava pelo Pará, Maranhão, Ceará, Rio Grande do Norte, Paraíba, Pernambuco e Bahia, justamente para ajudar os militantes do MEP na construção do $\mathrm{PT}^{237}$. Ao ser perguntado sobre essa construção no Pará, responde Luiz Araújo:

"Estivemos presentes desde o início, pessoas simpáticas ocuparam cargos chaves nas primeiras direções. Depois que superamos as dificuldades do racha voltamos a ter presença importante, especialmente após a fusão. Estivemos presentes em todas as instâncias tanto do PT quanto da CUT no estado.Nós tomamos uma decisão de investir no PT e disputar seus rumos muito cedo, desde cedo e isso ajudou muito. Na época a convivência com a articulação não estava deteriorada como ficou no período seguinte, pelo menos no Pará, e se fazia muita coisa unitária"238.

Nesse começo, o MEP possuía relações internas mais próximas com o PRC (Partido Revolucionário Comunista), a DS (Democracia Socialista) e mantinha boas relações com o que veio a ser a articulação dos $113^{239}$. Evidentemente, com o passar do tempo, esse quadro de alianças se modifica profundamente. O jornal Companheiro, vale destacar, foi usado como ferramenta de estímulo e construção do Partido dos Trabalhadores. Curiosamente, ao passo da dedicação do MEP à construção do PT, com o tempo, exatamente por este motivo, a organização passou por forte crise interna, como veremos mais à frente.

\subsection{Jornal Companheiro}

Fazia parte da tradição das organizações leninistas possuir um jornal que objetivasse divulgar o conjunto das lutas e, por outro lado, discutisse temas de interesse do movimento dos trabalhadores. O MEP, desde a Fração Bolchevique, possuía o periódico Nova Luta. Todavia, este circulava de maneira restrita, afinal, o começo da década de 1970 o colocava espontaneamente na clandestinidade. Cabia,

237 Entrevista concedida em 09 de abril de 2019.

238 Contribuição enviado por escrito pelo autor em 10 de abril de 2019.

239 Cadernos Perseu. Memória e História. №3. O Socialismo nas resoluções de encontros e congressos do Partido dos Trabalhadores. Entrevista com José Genoino. Pg. 44. 
então, possuir um material legal, que pudesse circular em larga escala. Teorizavam que, se a burguesia possuía as suas tecnologias de dominação ideológica das massas - como os jornais impressos, rádio e televisão, cabia aos socialistas apresentar um contraponto ao conjunto dos trabalhadores.

Essas ideias se condensaram com a criação do jornal Companheiro ${ }^{240}$. Nascido em abril de 1979, o periódico podia circular livremente. Através dele o MEP expressava a sua interpretação sobre os fatos da época. Estimulava as lutas. Investia na construção do PT. É verdade que o Companheiro, de algum modo, se afastou da condição de jornal da tendência, no sentido de ser uma espécie de canal oficial do que fazia e pensava o MEP. O Companheiro tinha um caráter jornalístico e não meramente propagandístico, voltado para pequenos círculos. Cada militante do MEP, no entanto, deveria fazer circular o periódico, que também exercia a função de construir identidade em torno do grupo. Tratava-se de uma tarefa militante.

O jornal Companheiro pode ser comparado com outros periódicos, como o Movimento, Opinião, Em Tempo e Versus ${ }^{241}$, com, evidentemente, especificidades. Sem embargo, a informação de que o Companheiro fazia parte de uma iniciativa do MEP era pública e notória.

O jornal expandiu-se rapidamente, justamente na esteira da dimensão nacional que o MEP havia adquirido. Chegou ao Rio Grande do Sul, Santa Catarina, Paraná, São Paulo, Espírito Santo, Minas Gerais, Pernambuco, Maranhão, Ceará e Pará. Vários nomes estavam de algum modo associados ao Companheiro, muitos dos quais ligados à área da educação. Do Pará, Edmilson Rodrigues, Aldenor, Júnior, Luiz Araújo e Venice. De Pernambuco, Paulo Ruben Santiago. Por Minas, Luiz Dulce. Em São Paulo, Paulo Frateschi, Gumercindo Milhomen, Bia Pardi, Celso Daniel, Mirian Belchior, dentre muitos outros. O Companheiro se tornou um centro

240 Todos os números do jornal Companheiro encontram-se no Centro Sérgio Buarque de Holanda da Fundação Perseu Abramo.

241 Quanto a esses três jornais, informações podem ser encontradas em Kucinski, Bernardo. Jornalistas e Revolucionários. Editora Scritta. São Paulo, 1991. Vale aqui registrar que ainda não houve pesquisa satisfatória a respeito do jornal Companheiro. Pela duração e vasta circulação, certamente este periódico merece ter melhor registro no campo da reflexão sobre a imprensa alternativa. 
aglutinador de dezenas de dirigentes políticos.

Um dos primeiros editores, Ivan Valente comenta que o jornal funcionava em uma casa geminada, com quatro cômodos e um pequeno quintal, na rua Itapeva ${ }^{242}$, na Bela Vista. O jornal era feito manualmente, inclusive a diagramação, responsabilidade esta nas mãos de Lúcio. A cada quinze dias, Ivan e Lúcio Leal levavam o material às seis horas da manhã para ser rodado em uma gráfica no bairro da Liberdade. Com variações de tiragem, chegaram a ser impressos 25 mil exemplares. O foco era a distribuição em assembleias de operários.

No começo, os diretores responsáveis eram Rosane Pinheiros e Tânia Coelho. Na Consultoria Jurídica, Idibal Piveta e Paulo Gerab. Contribuíam com a equipe de redatores e disseminadores Adélio, Aguinaldo Meyer, Beto Borges, Edérico Fanasca, Ethel Leon, Indiana Cardoso, José de Ângelo, José Roberto Siracusa, José Carlos Varlotta, Leila Stein, Luiz Antoio Bongiovanni, Luiz Antônio Carvalho, Luiz Diniz, Maria Bernardete Entratice, Maria Margaret Lopes, Olenka Aires Barreira, Sérgio Squilanti e Vitória Helena Facchina. Do Rio de Janeiro, local que também possuía uma sede do jornal - na rua Riachuelo, Lapa - compunham o time de redatores André Luiz de Campos, Ângela Matos, Custódio Coimbra, Erika Franziska, Francisco Lameirão Jr., Frida Albuquerque, José Ricardo Cardoso, Leni Rocha, Luiz Arnaldo Campos, Luiz Ricardo Figueiredo, Sérigo Cardoso, Sérgio Provisano e Simone Katz.

Por Belo Horizonte, Aurélio Silby, Célia Gontijo, George Abner e Maria Luiza. De Porto Alegre, Ademar Vargas, Antonio Soave, Ivanir Zandoná, Neusa Ribeiro, Rubens Turkiewicz. Do nordeste, Salvador, Ângela Serravale e Jorge Fernandez. Correspondentes em Vitória, Aracaju, Recife, Paris e Bruxelas. A diagramação cabia ao Lúcio Leal ${ }^{243}$.

Luiz Araújo busca sintetizar o papel do jornal:

"Era um elemento organizador. A comunicação de posicionamentos era precária, o norte era

242 Em entrevista realizada no dia 06 de abril de 2019, Ivan Valente nos revelou o funcionamento do jornal em seu início.

243 Informações retiradas da nota técnica do jornal Companheiro, №3, de 8 a 21 de maio de 1979. 
longe, caro para ter presença de assistentes com frequência e nossas regras de segurança eram mais ou menos rígidas. Assim, o jornal sempre foi, para a esquerda nesta transição para a legalidade, uma forma de aproximar pessoas. Vendíamos o jornal e usávamos suas matérias para divulgar nossas posições, para aproximar pessoas no movimento estudantil, principalmente. No Pará atuávamos em três áreas (movimento popular, estudantes e professores) e o jornal era importante"244.

A primeira capa do Companheiro estampava uma manifestação dos professores na Praça da Sé. A manchete, categórica: "A classe operária veio para ficar". As notícias apresentadas, no conjunto dos números, tinham a ver com as lutas políticas. Temas como o arrocho, a anistia e a construção do PT davam a tônica. Mas não só. A reconstrução e os desafios colocados para a União Nacional dos Estudantes, a construção da Central Única dos Trabalhadores, os desafios do movimento operário e suas oposições. Denúncias contra a máquina da repressão da ditadura que continuava em operação eram constantes. O caso do assassinado do operário Santo Dias, durante a greve geral metalúrgica em São Paulo, estampou uma das capas. Havia uma política de entrevistas com lideranças políticas e intelectuais, como José Ibraim, Manoel da Conceição, Apolônio de Carvalho, Lula, Francisco Weffort, Florestan Fernandes, dentre outros. Novidades passaram a ser discutidas, como a questão feminista e reflexão sobre a sexualidade ${ }^{245}$.

Além dos redatores, muitos ajudavam na logística. Dois professores, na época ligados à oposição na Apeoesp, ajudavam nesse sentido: Mário Barba e Aguinaldo. Valente conta da publicação de um encarte especial com o texto "Sobre as greves", de Lênin, que teve altíssima aceitação. Operários iam até a sede do jornal buscar exemplares dessa publicação ${ }^{246}$. O crescimento do Companheiro apareceu no radar da extrema-direita, que explodiu uma bomba na sede ainda em 1979. Ninguém saiu ferido.

Embora tenha tido razoável circulação, dada as dificuldades materiais, ficava

244 Contribuição enviada por escrito pelo autor em 10 de abril.

$245 \mathrm{Em}$ uma trajetória de vinte anos, temas até então considerados menores ou pequeno-burgueses passaram a entrar em cena, embora permanecessem, de algum modo, em um segundo escalão de prioridades.

246 Entrevista com Ivan Valente, em 06 de abril de 2019. 
difícil sustentar a produção e divulgação nacional do jornal. Desse modo, em seu terceiro ano, o №66, do dia 15 de dezembro de 1981, é o último a ser apresentado. Não sem atacar a ditadura através de sua manchete de capa: "Figueiredo quer arrebentar as eleições de 1982". Tratava-se de manobras eleitorais para favorecer o PDS, partido do governo. A foto ilustra uma manifestação, em Florianópolis, de petistas contrários às manobras. A faixa estampava uma antiga palavra de ordem: "por um governo dos trabalhadores"247.

\subsection{Movimento estudantil}

O MEP, desde a Fração, teve inserção no movimento estudantil. Foi justamente seu crescimento, sobretudo nessa área, que despertou os radares da repressão no Rio de Janeiro. Não que fosse fácil a atuação. Era clandestina, molecular, repleta de riscos. Depois da decretação do Al-5, o movimento estudantil, de maneira geral, passou por longo período de sufocamento. Ao lado deste Ato Institucional, outros dois decretos atuavam especificamente para impedir a ação política na área: o Decreto-lei 228, de 28 de fevereiro de 1967, que previa a punição inclusive de reitores "condescendentes" com a subversão, e o n²477, de 26 de fevereiro de 1969 , o qual estabelecia punições de caráter administrativo-penal para quem questionasse a ditadura nos marcos de instituição de ensino, compunham um duro arcabouço repressivo ${ }^{248}$.

Após a queda do Congresso da UNE de Ibiúna, os estudantes ainda tentaram manter suas atividades políticas, na clandestinidade, sem muito sucesso. A repressão foi cruel com as principais lideranças. Luiz Travassos foi preso, José Dirceu e Jean-Marc, banidos, José Genoíno, preso, Helenira Rezende, morta, Honestino Guimarães, assassinado, Humberto Albuquerque Câmara consta na lista de desaparecidos, José Carlos, morto. Esses são somente alguns exemplos. Sem

247 O jornal Companheiro demanda análise mais aprofundada, pois trata-se de importante fonte relacionada ao período 1979-1981.

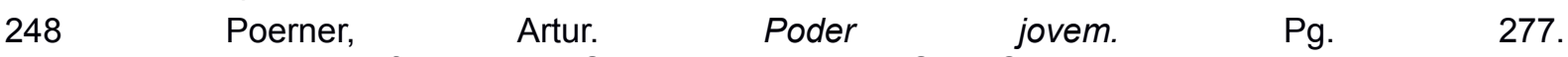
(https://docs.google.com/file/d/0BzFjYS2mqlc9RmE4MWk2S1RoOFk/edit) 
embargo, algumas mobilizações, esparsas, ocorreram. Podemos citar os atos contra a presença de Nelson Rockefeller, em 1969; as mobilizações que lembravam Edson Luís, em 1970; denúncias de prisões em São Paulo e no Rio de Janeiro; a missa que se tornou um ato, na Praça da Sé, em resposta ao assassinato do estudante Alexandre Vannucchi Leme, em 1973; a criação do Comitê de Defesa dos Presos políticos da USP, em 1974; a greve nessa mesma universidade, em razão do assassinato do jornalista Vladimir Herzog nas dependências do DOI-CODI, em 1975; a fundação do DCE-Livre da USP, batizado Alexandra Vannuchi Leme e dois encontros nacionais de estudantes, todos esses eventos em $1976^{249}$.

Março de 1977, no entanto, marca a retomada das ruas por parte do movimento estudantil. As reivindicações eram concretas, tais como mais verbas para a universidade, rebaixamento das anuidades no ensino superior privado e o fim da perseguição política. Em 30 de março, uma pequena multidão de estudantes saiu da Cidade Universitária até o Largo de Pinheiros, passeata essa proibida por Erasmo Dias. Uma assembleia na PUC de São Paulo, em meados de abril, juntou o estudantado que também se levantava contra o "pacote de abril" de Geisel. Em cinco de maio, no centro de São Paulo, 15 mil estudantes apresentaram uma nova carta aberta à população, na qual denunciavam a exploração econômica, o arrocho e as péssimas condições de vida. As manifestações, nessa altura, ocorriam em universidades de norte a sul do país ${ }^{250}$.

Em julho de 1977 ocorreram as quedas do MEP. Ainda que limitado pela ação repressiva, o trabalho do grupo nas universidades, em especial no Rio de Janeiro, girava em torno da campanha pela liberdade dos presos políticos ${ }^{251}$.

A tentativa de reconstrução da UNE ganha fôlego. Foi articulado um Encontro Nacional de Estudantes (ENE) para junho de 1977, em Belo Horizonte. A ditadura impediu que o encontro ocorresse. Centenas foram presos. No entanto, clandestinamente, o ENE foi realizado na PUC, no fim de setembro, de onde saiu a

249 Idem. Pg. 279.

250 Ibidem. Pg. 282.

251 Ver capítulo 4. 
Comissão Pró-UNE. Como represália, o coronel Erasmo Dias comandou pessoalmente a famosa invasão da PUC, ainda em setembro, marcando um ataque brutal com centenas de prisões ${ }^{252}$.

Em 1978, seguiam os protestos contra a ditadura e por melhorias na educação. No centro das atenções, porém, estava a reorganização da UNE. Outro Encontro Nacional de Estudantes, ocorrido em outubro na FAU-USP, marcou o Congresso de Reconstrução para o fim de maio de 1979, em Salvador. Nesse momento, as principais tendências eram a Liberdade e Luta (Libelu, ligada à Organização Socialista Internacionalista), Alicerce (Convergência Socialista), Unidade (PCB), MR8 (Mãos à Obra), Caminhando (PCdoB), Refazendo ( $\mathrm{PPML}$ ) e Correnteza (PCR). $\mathrm{O}$ braço estudantil do MEP era Organizando.

Enquanto a Comissão Nacional Pró-UNE seguia com os trabalhos de organização do $31^{\circ}$ Congresso, o da reconstrução, no dia 15 de março, foi um dia de mobilização contra a posse de João Batista Figueiredo. Enfim, entre 29 e 31 de maio, em Salvador, a União Nacional dos Estudantes voltou a dar as caras, ainda que permanecesse na clandestinidade, publicamente ${ }^{253}$.

As polêmicas giravam em torno da questão democrática e de como os estudantes deveriam se posicionar frente ao processo de redemocratização, a centralidade da disputa da educação, o papel da esquerda no movimento estudantil, a razão de ser das entidades estudantis, o Partido dos Trabalhadores, dentre outros pontos.

Fato é que o MEP se posicionava como sujeito ativo diante de todo esse quadro. O documento "Anteprojeto de linha de massa para o setor estudantil" 254 apresenta, em suas longas páginas, um balanço do movimento e as perspetivas do MEP para a área ${ }^{255}$.

252 Ibidem. Pg. 286.

253 Ibidem. Pg. 289.

254 Documento localizado no CSBH.

255 Não há data no documento, embora tudo indica que tenha sido escrito entre o fim de 1979 e início de 1980, posto que dentre as principais campanhas assinaladas estava a legalização do Partido 
O documento se divide nas seguintes partes: "Lutas populares e construção do partido", "Balanço e situação do movimento estudantil", "Pontos para uma política de construção partidária e para o fortalecimento de uma direção revolucionária no movimento estudantil" e "Nossa política para as entidades".

Antes da apresentação das formulações, algumas moções são apresentadas. Sobre o Ativo Nacional, já ocorrido, passam a denominá-lo $1^{\circ}$ de maio, uma vez que entendem que a política acertada para o movimento estudantil é aquela que o liga ao movimento operário. Sobre o Ativo Estudantil do Rio de Janeiro, em memória honrosa aos militantes do MEP que foram presos, muitos estudantes, passam a denominá-lo "12 de dezembro", data da libertação dos militantes. Anunciam ainda uma moção sobre a importância da construção partidária, no caso, o próprio MEP, e a necessidade da organização marchar para o seu II Congresso.

Como ponto de partida, inciam com um dado fundamental que pauta a política estudantil, ou seja, as lutas operárias e populares. Entendem que segue com a classe operária o imperativo de seguir como vanguarda da luta política, sendo prioridade a construção do partido do proletariado. Nessa direção, cabia agir também o setor estudantil do MEP. Para tanto, era necessário evitar a prática de "tendência", o que significa não agir de maneira isolada, autoproclamada, deslocada do conjunto das mobilizações. Os desafios, portanto, giravam em torno da integração do estudantado às lutas populares e a unificação nacional das lutas estudantis.

Em relação ao balanço, o MEP reconhecia o longo e difícil caminho até as jornadas de maio e junho de 1977, dado o contexto de repressão. Destacam, em junho de 1977, as manifestações contra a prisão de operários e estudantes no contexto do $1^{\circ}$ de maio. As palavras de ordem eram anistia ampla, liberdade para os presos políticos e o fim das torturas. A abertura das entidades de base, como os Diretórios Centrais dos Estudantes e as Uniões Estaduais dos Estudantes como pontos fortes da mobilização, assim como o $4^{\circ} \mathrm{ENE}$, preparatório para $\circ 31^{\circ}$ dos Trabalhadores. 
Congresso da UNE.

Do ponto de vista do ensino, compartilhavam da crítica à falta de verbas, baixa qualidade dos processos formativos, as privatizações através da expansão das universidades particulares e a chegada de autarquias e fundações, que criavam elo entre a universidade e o mundo empresarial. Sem embargo, consta uma autocrítica, no sentido do reconhecimento do baixo nível das formulações nesse campo.

Entendiam que as entidades precisavam se transformar em canais de participação e organização do conjunto dos estudantes e fortalecer uma direção política revolucionária. A principal crítica apontada ao conjunto do movimento estudantil se dava pela pouca integração ao movimento operário e também ao movimento pela anistia.

Em relação à política partidária e à disputa de rumos no movimento, apostavam na formação de círculos amplos, diferentes da prática de tendência, de modo a contribuir com a formação política dos estudantes e com a integração das diversas lutas. O jornal partidário legal era a principal ferramenta para a agitação em torno desses círculos. Já no campo de agitação e propaganda, a tarefa posta era elevar o nível de consciência. Como referencial, estava o programa político do proletariado. Impulsionavam a agitação oral - formavam militantes para cumprir essa tarefa -, a utilização de faixas e cartazes em manifestações. Davam ênfase também à imprensa das entidades estudantis, como instrumentos de trabalho junto ao estudantado.

O MEP caracterizava as principais correntes do movimento estudantil do seguinte modo: PCB e MR-8 eram reformistas; APML e PCR agiam com espírito de tendência; OCML-PO, Organização Socialista Internacionalista e a Convergência Socialista eram sectárias. Já o PCdoB possuía características ambíguas. No que se refere ao arco de alianças no contexto da UNE, priorizavam a relação com a APML e setores de esquerda do PCR e do PCdoB.

O PT também estava no rol das prioridades da política estudantil do MEP. A legalização do partido era considerada tarefa prioritária, uma vez que esta constituía 
em uma frente ampla, que amalgamava o conjunto dos movimento populares. $\mathrm{O}$ MEP deveria organizar células em prol da construção do PT, o que não deveria implicar em instrumentalização do movimento.

O MEP defendia a construção e a atuação através das entidades estudantis, entendia como necessário combater o "aparelhismo" e apostar no respeito à independência, o que não implicava em apartidarismo. Das tarefas urgentes, estavam postas a necessidade de superar o problema do afastamento das entidades em relação aos estudantes e o fortalecimento dos canais diretos. Incentivavam a massificação do movimento, através das assembleias e congressos, do fortalecimento dos DCEs, UEEs e da UNE. Estas eram as principais entidades deliberativas do movimento estudantil, às quais deveriam se centralizar as lutas. Valorizavam também o papel dos conselhos de representantes e davam ênfase ao trabalho das diretorias.

O MEP desenvolveu trabalho estudantil em diversos estados do Brasil. Em São Paulo, o mais sólido se deu na Escola de Engenharia Mauá, embora tivesse presença na USP. No Pará, Minas Gerais e Pernambuco houve entrada. O destaque seguia com o Rio de Janeiro, onde ocorreu entrada substancial na Federal Fluminense, na PUC, UFRJ e, sobretudo, na UERJ. Nacionalmente, o MEP não conseguiu se estruturar de maneira aprofundada nas disputas da UNE, mas a organização deixou sua marca no movimento estudantil.

\subsection{Movimento pela Emancipação dos "professores"}

Dada a entrada do MEP junto ao trabalho na educação em várias regiões do país, circulava uma brincadeira que dizia ser a sigla MEP "Movimento pela Emancipação dos Professores". Fazia sentido. No final dos 1970, militantes ligados à organização começaram a atuar nas chamadas oposições aos sindicatos oficiais. 
Logo, o grupo alcançou posição de destaque em várias experiências nacionais. A mobilização dos professores ressurgia ao lado do chamado "novo sindicalismo" 256 .

Em São Paulo, a APEOESP, então Associação dos Professores do Estado de São Paulo, era uma entidade meramente assistencialista, adequada aos moldes impostos pela ditadura militar ${ }^{257}$. Em meados dos anos 1970, voltaram a surgir articulações políticas que buscavam pautar reivindicações, como fim do arrocho salarial, estabilidade para professores com contratos precários e $20 \%$ de horaatividade $^{258}$. Nesse contexto, aparecem iniciativas como o MUP (Movimento de União dos Professores) e o MOAP (Movimento de Oposição Aberta dos Professores). Ambos questionam a letargia da Apeoesp e buscaram organizar as lutas da categoria. O MOAP foi um movimento criado pelo MEP para atuar ao lado dos professores. Lideranças como Paulo Frateschi e Gumercindo Milhomen, Bia Pardi e Antônio Bonfim Moreira se destacavam nessas articulações ${ }^{259}$. Em maio de 1977, uma assembleia histórica da categoria escreve uma carta de reivindicações e cria uma Comissão Aberta, com autonomia frente ao sindicato, para estimular a participação de professores e criar canais diretos de negociação com o governo de São Paulo, então chefiado por Paulo Egydio. As oposições atuavam com o objetivo de desbancar a direção oficial do sindicato. Em contrapartida, os radares da repressão também se voltaram para elas. O presidente da Apeoesp à época, Rubens Bernardo, foi ao DEOPS, aonde supõe-se que tenha delatado membros da oposição. Na mira, estavam Paulo Frateschi, Antônio Bonfim Moreira, Antônio Celso e Gumercindo Milhomen ${ }^{260}$.

256 Miranda, Kenia. As lutas dos trabalhadores da Educação: do "novo sindicalismo" à ruptura com a CUT. Tese apresentada ao Programa de Pós-Graduação em História como requisito para obtenção do Grau de Doutor em História. Área de concentração em História Social e Política. Pg. 51. (http://www.historia.uff.br/stricto/teses/Tese-2011_Kenia_Miranda.pdf)

257 Paula, Ricardo Pires. Uma História de Apeoesp (1945-1989): entre o sacerdócio e a contestação. Editora Paco Editorial. Jundiaí, 2011. Pg. 125.

258 Idem. Pg. 166.

259 Entrevista concedida por Inês Paes em 18 de junho de 2019.

260 Ibidem. Pg. 169. 
Em 1978, à revelia da direção do sindicato, a Comissão Aberta declara greve a partir do dia 19 de agosto. Durou 24 dias. Foi a primeira greve de professores em São Paulo desde 1963. Embora enfrentando dificuldades, a categoria logrou $20 \%$ de reajuste. A oposição, embalada, após dirigir o movimento através do Comando de Greve, transformou-se em CEPEU (Comissão Pró-Entidade Única), que tinha a intenção de unificar as categorias da educação e aproximar-se das outras do funcionalismo público estadual. Ocorreram eleições sindicais em 1979. Quatro chapas participaram ${ }^{261}$. A primeira, situacionista, "União e Luta", liderada pelo professor Antonio José do Nascimento. A segunda era a chapa da CEPEU, encabeçada pela professora Eiko Shiraiwa. Eiko era ligada à Libelu (Liberdade e Luta). Chamada "Pró-Entidade Única", a chapa sagrou-se vencedora, mas assumiu somente após disputa judicial. As outras duas eram "A Voz dos Professores", com Raul Schwinden na cabeça, e "Movimento Moderador", com Milton Moraes ${ }^{262}$.

Interessante notar que a liderança com mais destaque da oposição era Gumercindo Milhomem, que foi impedido de ter o nome inscrito na chapa justamente por ter entrado nos radares da repressão ${ }^{263}$. Nesse momento, o MEP defendia uma política de massas para o sindicato, estimulando a criação de locais de articulação regionalizados, o que mais tarde se tornaram as subsedes ${ }^{264}$.

O Congresso da Apeoesp de 1980, ocorrido em Sorocaba, deu um salto de qualidade na organização dos professores, pois foi aprovado o estatuto e a entidade fortaleceu seu status sindical. Nas eleições de 1981, a chapa consagrada nas lutas de 1977 se reelegeu. Dessa vez, com Gumercindo levando a presidência do sindicato ${ }^{265}$.

Em Minas Gerais, um roteiro de luta semelhante ocorreu a partir de 1979. Este ano marcou o Congresso dos Educadores de Minas Gerais, no qual 500 delegados se reuniram na Faculdade de Direito, em Belo Horizonte. Foi fundada a União dos

261 lbidem. Pg. 211.

262 Pg. 211.

263 Entrevista concedida por Inês Paes em 18 de abril de 2019.

264 Idem.

265 Ibidem. 
Trabalhadores do Ensino de Minas Gerais, mais tarde Sindicato - UTE/MG. Estourou uma greve em maio, a qual durou 41 dias. O marco foi uma assembleia que reuniu 10 mil pessoas na Assembleia Legislativa. No dia 29, uma grande repressão se abateu em nova assembleia, dessa vez ocorrida na Praça da Liberdade. A repressão se sobrepôs ao movimento. No entanto, nos dias 1 e 2 de novembro, ocorreu o II Congresso dos Trabalhadores em Educação, o qual escolheu a primeira diretoria e o estatuto ${ }^{266}$.

No embalo do II Congresso, outra greve foi articulada, tendo começado em 22 de abril de 1980. Luiz Dulce, Fernando Cabral, Luís Fernando Carceroni, Antônio Carlos Ramos Pereira e Luis Magalhães foram presos e, em 03 de maio, iniciaram greve de fome pela abertura de negociação, fim da repressão e atendimento às reivindicações. A resposta por parte do governo, todavia, foi mais repressão ${ }^{267}$. Dulce era a liderança do MEP.

Já em 1982, os trabalhadores do ensino organizam o $5^{\circ}$ Congresso da categoria, o qual cumpre papel organizativo, no sentido de estabelecer funções ao Conselho Geral da entidade, o funcionamento do processo eleitoral e a eleição de uma diretoria extraordinária que cumpre o papel de conduzir a UTC/MG junto ao processo de criação da Central Única dos Trabalhadores ${ }^{268}$.

Vale a pena destacar o cometário feito por um professor do MEP, que atuava no Pará, acerca do trabalho político que a organização desenvolvia nessa categoria. Luiz Araújo comento que:

"O MEP chegou a desenvolver trabalho muito forte entre professores, tanto em estados como SP, RJ, MG e PA, quanto em entidades nacionais da área. Como foi

266 Oliveira, Wellington. A trajetória histórica do movimento docente de Minas Gerais: da UTE ao Sind-UTE. Tese apresentada ao programa de Pós-Graduação em Educação na linha de pesquisa Movimentos Sociais da Faculdade de Educação da UFMG como requisito parcial à obtenção do título de doutor em Educação. Pgs. 66; 69; 92. Disponível em

(http://www.bibliotecadigital.ufmg.br/dspace/bitstream/handle/1843/HJPB-6QJQTY/2000000104.pdf? sequence $=1$ )

267 Entrevista concedida por Inês Paes em18 de abril de 2019.

268 Oliveira, Wellington. A trajetória histórica do movimento docente de Minas Gerais: da UTE ao Sind-UTE. Pg. 172. Ver também nota histórica: http://sindutemg.org.br/institucional/nossa-historial . 
esse processo de crescimento? Como se deu a entrada do MEP entre os professores? Então, o MEP realmente, quando entrei, possuía influência nos sindicatos de São Paulo, Minas, Pernambuco [com Paulo Rubem Santiago], Rio de Janeiro e começamos a ter presença no Pará. Três anos após a minha entrada na organização, me tornei professor e fui eleito secretário-geral da entidade criada (FEPPEP). Naquele momento, a presença organizada não era explícita"269.

Do ponto de vista nacional, havia a Confederação dos Professores do Brasil (CPB). As organizações de esquerda e os grupos identificados com o "sindicalismo autêntico" consideravam esta uma entidade sindical de "carimbo" e ligado ideologicamente ao regime militar. Para estabelecer um contraponto, criaram, com a participação destacada do MEP, a União Nacional dos Trabalhadores em Educação (UNATE), em $1981^{270}$. Professor e militante da zona leste de São Paulo, Mário Barba era um dos principais militantes do MEP nessas articulações nacionais ${ }^{271}$. Em 1990, a CPB tornou-se Confederação Nacional dos Trabalhadores em Educação (CNTE).

As mobilizações do professorado tiveram grande relevância no final dos $1970 \mathrm{e}$ início dos anos 1980. Ao lado do "novo sindicalismo", através das reivindicações econômicas, enfrentavam politicamente a ditadura militar, que então caminhava para o seu fim. Se, por um lado, o MEP possuía trabalhos incipientes no movimento operário, na educação, a organização desenvolveu protagonismo nacional. O racha vivido pelo MEP, em 1982, enfraqueceu o trabalho nessa área. As principais lideranças passaram a se organizar com o que se tornou a "Articulação dos 113". Todavia, a ação coletiva do Movimento pela Emancipação do Proletariado, entre 1977 e 1982, momento efervescente, merece destaque nas batalhas dos trabalhadores em educação.

269 Contribuição enviada por escrito pelo autor em 10 de abril de 2019.

270 Kenia, Miranda. As lutas dos trabalhadores da Educação: do "novo sindicalismo" à ruptura com a CUT. Pg. 40.

271 Entrevista concedida por Inês Paes em 18 de abril de 2019. 


\subsection{Movimento de bairro}

Desde seu congresso de fundação, o MEP discute a importância de disputar o território urbano, por entender que a luta de classes também o tem como palco. Ainda que não carregue lugar de destaque na memória comum sobre o MEP, a atuação em bairros periféricos de várias cidades do país foi marcante na vida da organização. Parte significativa dessa iniciativa se desenvolveu no esteio da luta contra a carestia, das comunidades eclesiais de base e com a construção do Partido dos Trabalhadores. Sem embargo, houve um trabalho de reflexão intelectual para colocar em prática a atuação territorial.

A revista Teoria e Prática, então editada pela organização com a finalidade de aprofundar sobre alguns temas, dedica um número à reflexão exclusiva sobre a atuação política em solo urbano. Com o título "Sobre movimentos sociais urbanos", apresenta três textos sobre o tema ${ }^{272}$. O primeiro é do pensador espanhol Jordi Borja, chamado "Elementos teóricos para a análise dos movimentos reivindicatórios

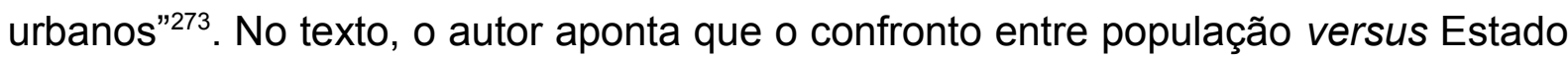
produz dois tipos de efeitos. Urbano, entendido como a modificação da relação equipamento/população. Político, sendo a transformação da relação da população com o poder no sistema urbano. Jordi afirma que o desenvolvimento da produção e divisão social do trabalho constrói novidades, como a expansão periférica e demandas por equipamentos urbanos. Este mesmo desenvolvimento, todavia, canaliza o capital para áreas lucrativas, deixando à revelia os problemas por ele próprio criados. Por outro lado, a administração pública se volta para as demandas do capital, ainda que o Estado fosse obrigado a manter o mínimo necessário para o funcionamento da atividade produtiva.

Frente a tal cenário, surge uma tipologia dos movimentos urbanos, estimulados pela deteriorização das condições de vida, alguma consciência política e pela espontaneidade. Assim sendo, surgem tipos de movimentos: (a) gerado pela

272 A revista em questão encontra-se no Centro Sérgio Buarque de Holanda da Fundação Perseu Abramo.

273 Este texto foi extraído de "Movimientos sociales urbanos", Ed, B. Aires-1975". 
deteriorização repentina das condições de vida; (b) gerado pela ameaça que representa a ação urbana, seja por parte do Estado ou do poder econômico; (c) como consequência de um deficit constante de habitação e outros serviços; e (d) como movimento de oposição à política urbana da administração. Os bairros são caracterizados como marginais, populares e interclassistas. Os movimentos reivindicatórios podem acontecer em todos eles, embora a frequência seja maior nos dois primeiros tipos.

Sobre as formas de organização, aponta organismos da administração pública, associações, centros, sindicatos, assembleias e reuniões entre vizinhos. Já sobre as formas de organização, petições públicas, manifestação de oposição, ações destinadas a criar situação de força. Conclui ao afirmar os efeitos desses movimentos. Por um lado, como consequência da mobilização, estariam os ganhos reais. Por outro, mais interessante, a força social gerada pelo processo de mobilização.

Chico de Oliveira figura como o autor do segundo texto, sendo este "Acumulação monopolista, estado e urbanização - a nova qualidade do conflito de classes" ${ }^{274}$. Nesse texto, Chico aponta que os problemas nacionais se refletem no urbano. A grande contradição trata-se de uma mudança construída pela entrada do "ciclo" do café. Antes a economia estava no campo, enquanto o poder, nas cidades, mas o eixo se transforma, de modo que o poder econômico passa a existir no solo urbano. O desenvolvimento econômico, pautado pela monopolização e pela ausência do Estado na solução das questões urbanas, suscita imenso caos social, produtor de lutas e resistências. O caos, como produto da evolução de uma economia de capitalismo atrasado, mostra as suas consequências numa dada psicologia da vida urbana. A questão do cotidiano foi apresentada no terceiro texto, de Henri Lefebvre, "Introdução à psicologia da vida cotidiana"275.

A partir desse arcabouço teórico, da experiência coletiva do MEP e da

274 Texto extraído de "Contradições Urbanas e Movimentos Sociais" - Co-edição CEDC.

275 Texto extraído de "Do rural ao urbano". Ed. Península - Espanha- 1974. 
efervescência social vista nas periferias das grandes cidades, a organização busca desenvolver o trabalho em bairros.

O Espírito Santo foi um dos lugares em que o MEP mais avançou. Das localidades, se encontram a Serra, onde havia participação no movimento de saúde, grupo de mulheres Eurico Salles e nos bairros São José e Taquara. Em Viana, com a pastoral e o movimento popular. Em Cariacica, havia atuação no movimento de bairro e operário em Campo Grande, além de mobilização relacionada ao transporte em Itaguaí. Já em Vitória, existia atuação em torno da questão da água nos bairros Itarari, Joana D'arc e Morro do Quadro. Por Vila Velha, atuavam junto ao movimento operário, amigos do bairro, nas CEBs e no movimento pró-morar. Em Linhares, havia atuação com os trabalhadores rurais. Por fim, em São Matheus, também desenvolviam trabalho no movimento de bairro e movimento no campo ${ }^{276}$.

No Rio de Janeiro, o MEP atuava através do Movimento Amigos de Bairro (MAB), que teve atuação na Favela Flor da Mina, Morro do Boréu, Vidigal, Guararapes, Chapéu Mangueira, Maré e Baixada Fluminense ${ }^{277}$. Em São Paulo, este tipo de atuação foi mais restrito que em outras regiões do país, embora destaque-se atuação no Jardim Miriam, na zona sul, e em São Miguel Paulista, na zona leste da capital $^{278}$. Em Minas Gerais, Pernambuco e Pará também havia participação. Como resultado do conjunto dessas iniciativas, o MEP organizou um ativo nacional para tratar do tema, ocorrido em março de 1980.

No ativo, sete regiões estiveram presentes ${ }^{279}$. Como de praxe, foram dados informes, feitas discussões em grupos, plenários e, por fim, um espaço de avaliação. Os grupos se dedicaram a alguns temas. O que primeiro veio à tona foi a utilização dos aparatos institucionais, como conselhos comunitários e centro sociais urbanos.

276 Estas informações foram retiradas da ata de uma assembleia do MEP dedicada a organizar a atuação no movimento popular no Espírito Santo. O documento se localiza no CSBH-Perseu Abramo.

277 Informações retiradas de uma ata da reunião do MAB. O documento se localiza no CSBH-Perseu Abramo.

278 Entrevista concedida por Miguel Carvalho, em 02 de abril de 2019.

279 As informações a seguir se referem à síntese do I Ativo Nacional de Bairros, documento localizado no CSBH-Perseu Abramo. 
Nesse campo, se dedicaram a pensar o aprofundamento da democracia através de mecanismos de participação direta e o potencial do PT nessa direção. A questão da Igreja foi abordada. Reconhecia-se que as suas comunidades de base tornaram-se espaços de resistência popular, embora a cúpula da igreja enquanto instituição permanesse com caráter reacionário, construindo assim uma ambiguidade.

O Partido dos Trabalhadores estava no centro da reflexão do trabalho de bairro. A sua existência como frente aglutinadora das diversas formas de insatisfação acabou se tornando polo propulsor das mobilizações territoriais. As lutas nos bairros e a construção do PT fundiam-se em um mesmo processo.

Interessante notar que, embora a repressão da ditadura tivesse diminuído, o tema foi abordado, no sentido de garantir regras de seguranças e alertar para a transformação da violência ditatorial em violência policial nas periferias. Todavia, a violência também era vista na carestia e nas privações que configuravam a pobreza.

A questão cultural era valorizada pelo seu aspecto bifurcado, uma vez que ela possuía características de aproximação das pessoas e politização do cotidiano. Através da cultura se poderia criar espaços acolhedores, forjar novos valores, apresentar o PT. Ao lado da cultura, tópico novo a ser pensado pelo MEP, o debate sobre a situação das mulheres ganha contornos mais claros. Vale a pena aqui uma pequena citação:

\footnotetext{
"considerando que a opressão da mulher, bem como o de minorias raciais, faixas etárias ou homossexuais são maneiras que o capitalismo se serve para manter e acentuar a exploração e que, no caso específico, a emancipação da mulher não se dá parte do processo revolucionário, é fundamentalmente ao nível do programa do nosso movimento" 280 .
}

Organização da massa, trabalho partidário/expansão dos círculos e agitação e propaganda fecharam os tópicos do Ativo Nacional. Vale dizer que os próprios presentes no encontro reconheciam alguma debilidade organizativa. No entanto, o interessante é a constatação de que os conflitos sociais não se produziam exclusivamente no chão da fábrica. Em solo urbano, novas contradições surgiam ou se tornavam mais aparentes, como as questões de saúde, transporte, moradia, cultura, meio ambiente, a opressão contra as mulheres, negros e a população LGBT.

280 O trecho citado encontra-se na mesma ata do Ativo Nacional de Bairros citada acima. 
O MEP construiu o entendimento de que a luta operária deveria acompanhar a vida do trabalhador para fora de seu local de trabalho. Tal reflexão expandiu as formas de organização do grupo. Sem dúvida, esse passo adiante no campo da formulação foi como um filho do tempo histórico, que tinha na construção do PT a principal marca.

\subsection{Rumo ao II Congresso}

Com este cenário no plano de fundo, o MEP caminhava para o seu II Congresso. O número 25 do jornal Nova Luta ${ }^{281}$, de fevereiro de 1982, faz uma convocação pública do encontro. O Congresso, que deveria ter ocorrido antes de acordo com o estatuto da organização, acabou sendo protelado em razão dos golpes desferidos pela repressão. Reerguido, o MEP passa a ser um elo sólido para a construção do partido revolucionário. A máxima instância da organização deveria congregar e sintetizar as várias experiências passadas. Assim como focar em dois desafios especiais, sendo eles 0 de desenvolver posições que contribuam com o fortalecimento do partido e comprometer toda a militância e a base social do MEP nessa tarefa.

Entendiam ser necessário atualizar as análises de conjuntura e a tática, avaliar criticamente a política de organização e a construção partidária. Sofisticar a elaboração do programa político, dando destaque para a questão internacional, a questão agrária e a questão das minorias, temas esses pouco desenvolvidos pelo grupo. Fazia-se necessário também colocar em patamar mais avançado a política de massas na área sindical, bairros, professores e estudantil. Diferentemente do I Congresso, o II se realiza de maneira mais aberta, permitindo críticas inclusive de fora da organização. O Nova Luta convida a participar militantes afins e organizações revolucionárias que compartilhavam da construção do partido revolucionário. 


\section{DO II CONGRESSO AO MCR}

Os anos que se seguiram às prisões assinalaram um crescimento vertiginoso do MEP. A organização, como vimos, nacionalizou a sua atuação. Passou a editar um jornal legal com escala considerável, desenvolveu trabalhos entre professores, estudantes, em bairros das periferias das grandes e entre operários. Desde o início da construção do Partido dos Trabalhadores, jogou peso nesse processo. Batalhou pela legalização do PT e cresceu junto com o novo partido de massas, algo há anos esperado pelo MEP. Contraditoriamente, o PT foi o grande motivo de desentendimento nas fileiras do Movimento pela Emancipação do Proletariado no episódio de seu II Congresso. O partido surgia como uma verdadeira expressão política dos vários movimentos questionadores da ordem ditatorial-burguesa. Ainda possuía a marca de nascer pela força do movimento operário, que então entrou em cena sem pedir licença.

O MEP ajustava a sua linha de atuação no sentido de fazer fundir o marxismoleninismo ao movimento operário vivo. A segunda parte passou tornou-se uma realidade. A primeira virou objeto de dúvidas entre os dirigentes do MEP. Cabia ou não imprimir a tradição leninista nessa nova experiência dos tralhadores? Alguns consideravam que era necessário manter uma organização política marxistaleninista para disputar os rumos do PT. Outros já enxergavam na força do partido a potência necessária para a mudança do Brasil.

Por mais que o MEP tenha entrada no PT logo em seu início, havia a desconfiança das tendências consideradas social-democratas ou reformistas. Viam o partido divido em dois campos, quais sejam, de um lado as organizações revolucionárias e os sindicalistas autênticos, por outro, pressão reformista vinda, sobretudo, de alguns parlamentares. Evidentemente, essa leitura se transformou com o passar dos anos. Uma ala do MEP passou a entender que a estrutura clandestina de caráter marxista-leninista dificultava a construção do PT, na medida em que essa dividia esforços de modo desnecessário. O PT se bastava. Essa era a aposta. Esse foi o signo da diferença que levou a organização que cresceu 
substancialmente a se dividir ${ }^{282}$. A história tem, de fato, as suas ironias guardadas.

A ala defensora da manutenção da tradição marxista-leninista argumentava, também, que o $\mathrm{PT}$, embora vivo, presente entre os trabalhadores, não era o partido comunista. No fundo, a divergência orbitava a noção de concepção de partido. Para a revolução, ainda era necessária a existência de um partido do tipo bolchevique ou a forma de partido de massas tornou-se mais adequada? Ivan Valente, Luiz Sérgio, Luiz Arnaldo, Edmilson Rodrigues, Wadih Damous, Luiz Araújo, Jorge Paes, Inês Paes e tantos outros militantes defendiam que o MEP deveria se manter como organização sólida para a disputa dos rumos do PT. Paulo Frateschi, Bia Pardi, Gumercindo, Miriam Belchior, Luiz Dulce, Luiz Antônio, dentre outros militantes, optaram por desembarcar no PT de corpo e alma. Eles vieram a compor o que veio a ser a "articulação dos 113 " 283 .

\subsection{Resoluções do II Congresso}

O II Congresso ocorreu em junho de 1982, em São Paulo. Embora rachado, resoluções e orientações políticas foram deliberadas. Em novo estatuto, o MEP se definia da seguinte maneira:

\footnotetext{
"Tendo como base teórica o marxismo-leninismo e assumindo o centralismo democrático como princípio de organização, nós nos constituímos enquanto uma Organização comunista, com o objetivo de participar ativa e organizadamente das lutas de nosso povo, promover o internacionalismo proletário, desenvolver a fusão do socialismo científico com o movimento operário vivo, construir o partido comunista de vanguarda da luta pelo socialismo, pela completa emancipação das classes trabalhadoras e pelo comunismo"284.
}

Reafirma como órgão máximo o seu Congresso Nacional, instância que escolhe o Comitê Nacional e estabelece as premissas a serem seguidas até o próximo Congresso. Volta assinalar o centralismo democrático como método de atuação

282 Ivan Valente nos ajudou a recompor o quadro dessa polêmica, em entrevista concedida em 06 de abril de 2019

283 A respeito do debate acerca da concepção de partido, mais para frente, os militantes que permaneceram no MEP passaram a defender a tese de um partido socialista, democrático e de massas, composto por quadros e filiados.

284 Estatutos do II Congresso, localizado no CSBH. 
interna. Proíbe a existência de frações, embora aceite tendências em época congressual. Define como critérios de militância a concordância com o programa da organização, a participação ativa nos fóruns do MEP e nos movimentos políticos, a aceitação das normas de comportamento de segurança e na prisão, além da contribuição sistemática em termos materiais. Aponta advertências em caso de faltas sem justificativas e ausência de contribuição, podendo ser suspensão ou mesmo expulsão.

Do ponto de vista do programa, reafirma o Brasil como monopolista dependente. O país possuí na indústria moderna seu elemento mais dinâmico, ainda que dependente de tecnologia e capital externos. Este, aliás, amarra o país através da dívida externa. Logo, os setores preponderantes da economia são o industrial e o financeiro. Aponta que o desenvolvimento do capitalismo fez surgir um grande setor agropecuário. Este mesmo desenvolvimento exige para o seu funcionamento um Estado altamente centralizado e repressivo. Ainda em relação à crítica ao desenvolvimento capitalista no Brasil, entende que este é incapaz de elevar o padrão de vida e dar soluções democráticas para as questões nacionais. Contraditoriamente, a evolução capitalista criou as bases materiais para a construção do socialismo.

Do ponto de vista política, a classe trabalhadora continua sendo responsável pelo trabalho de sua própria emancipação. Para tanto, o Estado e a divisão da sociedade em classes sociais precisam ser abolidos. O MEP se coloca como parte dessa tarefa histórica, ao lado dos trabalhadores. Tarefa essa a ser levada adiante, sobretudo, pela classe operária, com os camponeses pobres, trabalhadores em processo de proletarização, artesãos, intelectuais progressistas.

O caminho aponta se ancora na Revolução de Outubro, ou seja, a aposta na insurreição operária, com base nos órgãos de poder construídos pela classe no processo de desenvolvimento das lutas. Posta a realidade brasileira, as exigências mínimas para se fazer avançar a mudança socialista são ${ }^{285}$ :

285 Estas informações constam no Estatuto do Il Congresso do MEP, localizado no CSBH. 
- Extinção dos órgãos de repressão.

- Anistia ampla para todos que enfrentaram a ditadura militar.

- Extensão do direito dos votos a quem o tem negado, como militares de baixa patente e setores do funcionalismo público.

- Revogação do código civil, igualdade perante a lei entre homens e mulheres, respeito às tradições culturais, fim de qualquer punição pela prática do aborto, fim da discriminação de cor e sexo, liberdade de culto religioso.

- Eleições livres e diretas para todos os cargos governamentais. Criação do uma Assembleia Popular, composta pelo povo, para elaborar uma nova Constituição.

No que se refere à melhoria da qualidade de vida, aponta:

- Elevação geral dos salários.

- Eliminação das horas-extras. Estabelecimento da jornada de oito horas diárias e seis horas para trabalhos degradantes.

- Fim do desemprego.

- Universalização da previdência e assistência social.

- Congelamento dos preços considerados estratégicos, como os de produtos que compõe a cesta básica e os aluguéis.

- Nacionalização da medicina.

- Programa nacional de construção de moradias populares.

- Universalização do acesso à educação.

- Extensão dos direitos dos trabalhadores da cidade para os do campo.

Reafirmam a necessidade de nacionalizar os monopólios, controle operária da produção e distribuição de mercadorias. Aspectos relativos à independência nacional e a reforma agrária. 
Sobre a resolução partidária, elaboram novas definições ${ }^{286}$. Começam por comentar o desenvolvimento da luta de classes no século XX e a centralidade do partido político. A novidade em questão trata-se da perspectiva em relação ao Partido dos Trabalhadores. Afirma que existem no interior do PT correntes "autonomistas" que trabalham com uma noção vaga de partido da revolução. Por isso, abrem mãos da tradição leninista. Mais do que isso, entendem que a concepção de partido comunista encontra-se historicamente superada. Para o MEP, continua sendo central - leninismo. Outra crítica apontada direciona-se às correntes que pretendem "bolchevizar o PT". O MEP entende que essa perspectiva limita o potencial do PT como aglutinador dos diversos movimentos populares de dos trabalhadores. Logo, a linha deveria ser a de constituir um polo comunista do PT que seria o embrião da formação do partido revolucionário. O MEP se entende como uma das forças políticas mais aptas para essa tarefa, ao lado ala esquerda do PCdoB (Ala Vermelha).

Com o foco, então, de unificar os comunistas propõe um conjunto de tarefas: avançar em direção à unificação dos comunistas, fortalecer a unidade no campo de intervenção nos diversos movimentos, fortalecer a imprensa legal e clandestina, dotar o MEP de funcionamento partidário e desenvolver a organização de base. Para dar conta da aproximação com outras organizações, sugerem a superação do "patriotismo de partido", de modo a construir pontes mais camaradas de contato. Sintetizam a ideia propondo o aprofundamento da questão programática, a consolidação da concepção leninista de partido, a divulgação das resoluções congressuais na imprensa partidária, o avanço no trabalho de massas, a criação de cursos de formação militante e publicação regular da tribuna de debates.

\subsection{Do III Congresso ao MCR}

Enfraquecido com o racha do II Congresso, o MEP entra em um processo de buscar rearticular as suas forças. Presente no contexto, Luiz Arnaldo explica:

Após o II Congresso e a cisão interna, o MEP mergulha numa crise que tem origem na

286 O documento Resolução sobre a Questão Partidária do II Congresso do MEP encontra-se no $\mathrm{CSBH}$. 
contradição entre a decisão de "formar um partido com milhares de quadros" e a situação concreta da Organização, que, com o racha, perde praticamente todo o trabalho de São Paulo e do Nordeste, além de uma sangria de muitos quadros no Rio de Janeiro.

Em consequência, advém também uma crise de recursos que interfere na capacidade da Organização de intervir no movimento de massas e traz dificuldades para a manutenção do seu aparato clandestino.

Neste contexto e considerando a realidade que se delineia com a ampliação do espaço político e a afirmação de grandes partidos, como o PT e o PDT, importantes dirigentes começam a refletir se as pequenas organizações de combate "não teriam atingido o seu teto histórico" e sobre a conveniência de transformar o MEP numa tendência de um grande partido legal ${ }^{287}$.

Dessa maneira, aprofunda a política de aproximação com outras organizações consideradas comunistas. De algum modo, com esse espírito, a organização vai para o seu III Congresso, ocorrido em 1985.

Nas teses sobre construção partidária ${ }^{288}$, o MEP aponta que:

"O nosso objetivo é mobilizar o coletivo partidário para juntos discutirmos e encontrarmos uma solução para enfrentar a grave crise que vivemos. Assim, precisamos jogar nossos esforços na crítica e autocrítica e as consequentes definições e redefinições políticas de nossas posições que possam se concretizar no III Congresso, primeiro passo para rompermos o imobilismo e avançarmos nas tarefas centrais de construção partidária a serem desenvolvidas pelos comunistas revolucionários".

A resolução pouco avança em relação ao que foi determinado no II Congresso. Todavia, uma merece destaque. Quando apontam as tarefas no campo das questões políticas e de organização, propõem "fortalecer no PT a perspectiva revolucionária e socialista". A sugestão parece abrandada em relação à ideia de construção de um polo comunista que seria o epicentro da construção do partido comunista, embora essa ideia ainda conste na orientação geral.

O que estava, na prática, organizado e defino era o processo de fusão com outras duas organizações, que passavam por processo de dificuldade semelhante ao MEP: a Organização Comunista Democracia Proletária (OCDP), que vinha de uma dissidência da Ação Popular, sobretudo na Bahia, e o que restou da Ala Vermelha do

287 Contribuição enviada por escrito pelo autor, em 05 de maio de 2019.

288 Teses sobre Construção Partidária e Política de Organização do III Congresso, documento localizado no $\mathrm{CSBH}$. 
PCdoB. Mais uma vez, Luiz comenta que:

Assim, o MEP acaba por ver a saída na unificação com duas outras organizações comunistas: a Ala Vermelha e a Organização Comunista Democracia Proletária.

Surge o MCR, que terá uma trajetória virtuosa em diversos estados, particularmente no Rio de Janeiro, onde dirige simultaneamente 0 Sindicato dos Metalúrgicos, o Sindicato dos Ferroviários da Central do Brasil, participa da direção do Sindicato dos Metalúrgicos de Volta Redonda e preside por dois mandatos a CUT-RJ, sendo um dos protagonistas das Greves Gerais do período.

Como curiosidade lembramos que o MCR, por um breve tempo, editou um jornal legal que recebeu o nome de Nova Luta, numa homenagem ao órgão central do Movimento pela Emancipação do Proletariado 289 .

Combinando a compreensão comum da importância de criar uma organização política forte com a necessidade de sobrevivência, essas três organizações desembarcaram juntas no Movimento Comunista Revolucionário, em 1986. O MCR, ao lado de outras organizações da esquerda petista, exerce influência decisiva nas resoluções do $\mathrm{V}$ Encontro Nacional do PT. A proposta de Governo Democrático e Popular, como estratégia para o socialismo, passa a ser linha de todo o partido. Nessas resoluções, o MCR conseguiu imprimir a tradição "mepiana". Em 1989, quando não restava mais dúvidas de que a estrutura clandestina de organização não se fazia mais necessária e que cabia definitivamente construir o Partido dos Trabalhadores como ferramenta, ele próprio, da luta socialista, o MCR transforma-se em Força Socialista. Mas essas são páginas para um próximo trabalho.

289 Contribuição enviada pelo autor em 05 de maio de 2019. 


\section{CONCLUSÃO: À PROCURA DA REVOLUÇÃO BRASILEIRA}

O objetivo deste trabalho foi construir a trajetória do Movimento pela Emancipação do Proletariado como um intérprete coletivo da realidade brasileira. Um grupo intelectual orgânico, portanto militante, disposto não somente a entender o Brasil, mas transformá-lo em perspectiva socialista. É possível dizer que a vocação do MEP era a busca pela Revolução Brasileira.

Como lembram Lincoln Secco e Luiz Bernardo Pericás na introdução do livro Intérpretes do Brasil - clássicos, rebeldes e renegados, nos anos de 1920, com as experiências da Semana de Arte Moderna, a criação do PCB e o tenentismo, surgiu de maneira mais aprimorada um pensamento crítico e solidário à causa dos pobres e dos trabalhadores. Esse pensamento se desenvolveu e ramificou-se. É certo que os autores estão comentando sobre a obra de pensadores. No nosso caso, estamos falando de uma organização política. Uma organização que bebia dos clássicos, dos renegados e foi, ela mesma, rebelde.

A principal característica do pensamento do MEP foi a compreensão do caráter socialista da Revolução Brasileira. Sem dúvidas, o primeiro que deu base sólida a essa compreensão foi Caio Prado Júnior, através de seus clássicos Formação do Brasil Contemporâneo e A Revolução Brasileira. Ainda que com traços atrasados em sua formação econômica, o Brasil estava integrado às redes capitalistas.

Todavia, outros aspectos do pensamento de Caio foram incorporados pelo MEP, ainda que não de maneira mecânica. Luiz Bernardo Pericás, em seu livro Caio Prado Júnior. Uma biografia política, destaca que:

\footnotetext{
"No caso de Caio Prado Júnior, ele atua num ambiente partidário permeado pelo marxismoleninismo, muitas vezes deturpado e calcificado em dogmas. Aquele é o entorno político e cultural em que transita e no qual deve expor suas ideias, debater com dirigentes, discutir com teóricos. Em diversos aspectos, ele está mais próximo da essência leninista original do que vários de seus interlocutores ortodoxos.
} 
O historiador acreditava que não se devia copiar as experiências socialistas, mas aproveitálas convenientemente. Em outras palavras, tentar construir um socialismo "distinto"”290.

Essa formulação se encaixa perfeitamente na cultura política do MEP. Embora Caio Prado tenha influenciado a organização em questão, certamente ele não foi o único. O MEP utilizou de modo vasto a interpretação da economia brasileira apresentada por Chico de Oliveira na Crítica à razão dualista. Lá estava explicada a não-dualidade da realidade nacional.

Em seu texto, também clássico, Chico de Oliveira aponta que sua crítica tem o objetivo de:

"contribuir para a revisão do modo de pensar a economia brasileira, na etapa em que a industrialização passa a ser o setor-chave para a dinâmica do sistema, isto é, para efeitos práticos, após a Revolução de 1930. O exame que se tentará vai centrar sua atenção nas transformações estruturais, entendidas estas no sentido rigoroso da reposição e recriação das condições de expansão do sistema enquanto modo capitalista de produção"291.

Mais à frente, comenta que:

"o conceito do subdesenvolvimento como uma formação histórico-econômica singular, constituído polarmente em torno da oposição formal de um setor "atrasado" e um setor "moderno", não se sustenta como singularidade: esse tipo de dualidade é encontrável não apenas em quase todos os sistemas, como em quase todos os períodos. Por outro lado, a oposição na maioria dos casos é tão somente formal: de fato, o processo real mostra uma simbiose e uma organicidade, uma unidade dos contrários, em que o chamado "moderno" cresce e se alimenta da existência do "atrasado", se se quer manter a terminologia"292

Por este caminho, criticava-se a ideia de revolução por etapas e o reformismo. Ao lado de Caio Prado e Chico de Oliveira, autores como Moniz Bandeira, os formuladores da teoria da dependência, em especial, Ruy Mauro Marini, e, mais tarde, Florestan Fernandes, davam as diretrizes do pensamento "mepeano".

O MEP teve uma trajetória particular na esquerda brasileira. Vindo da POLOP, 290 Pericás, Luiz Bernardo. Caio Prado Júnior. Uma biografia política. São Paulo. Boitempo, 2016. Pg. 232.

291 Oliveira, Francisco. Crítica à razão dualista. Ornitorrinco. São Paulo. Boitempo, 2003. Pg. 30. 292 Idem. Pg. 32. 
buscou encontrar uma teoria da revolução brasileira, aliada à prática militante. Interessante notar que a organização não se filiava às tradições stalinista e trotskysta. Buscava inspiração no conjunto das lutas dos povos. Não por outra razão, ao longo da sua trajetória, destacava em suas publicações as datas das lutas históricas: grandes greves, insurreições, revoluções. No campo da formulação, as citações de autores marxistas eram diversas. Stalin, Trotsky, Bukárin, Talheimer, Rosa Luxemburgo, Mao Tse Tung, Fidel Castro, Che Guevera, dentre outros. Evidentemente, Marx e Lênin. O MEP parecia querer buscar o aspecto positivo de cada autor revolucionário. Sem dúvida, houve uma evolução nítida do pensamento da organização. A própria história parece ter obrigado algumas mudanças. Por exemplo, a própria crença aparentemente inabalável no papel central da classe operária na revolução atenuou-se com o tempo, abrindo espaço para mais setores do povo que também clamavam por saídas emergentes. A forma de organização política pautada na visão leninista de partido foi paulatinamente adequada aos novos tempos, sobretudo com a chegada do PT. Um tipo de ansiedade política que parecia antever a iminência da revolução cedeu lugar para uma visão que, resiliente, compreendeu que a revolução seria obra de milhões, em um processo de longa duração. Poderíamos dizer também que a noção de democracia, antes tão duramente atacada pela sua falta de conteúdo de classe, passou a ser defendida como um lugar melhor para as lutas populares.

O MEP viveu muitas experiências. Passou pela luta clandestina contra a ditadura militar. Sofreu a violência do regime nos porões do DOI-CODI. Por sobreviver e denunciar, contribui para o desgaste irreversível do governo dos militares. Cresceu ao lado de estudantes, professores, operários. Cresceu com o Partido dos Trabalhadores, visto com desconfiança em um primeiro momento, e ressignificado pelo seu próprio dinamismo. Essa experiência prática, baseada nas teorias acima, compõe o DNA do MEP. Tal arcabouço depositou-se do PT. Um dos principais registros disso encontra-se no documento em anexo, a Resolução Política do IV Encontro, em que foi desenhado programa democrático e popular para o socialismo.

O mais interessante é notar que a trajetória do MEP não se dissipou. 
Evidentemente, boa parte de seus quadros tomou rumos próprios. Muitos saíram da política. Outros não. Sem embargo, um núcleo orgânico do MEP seguiu lado a lado. Fundou o MCR, ao lado de outras organizações, como a Ala Vermelha e a Organização Comunista Democracia Proletária. No fim dos anos 1980, formou a Força Socialista. Em 2004, a Força torna-se Ação Popular Socialista, que então rompe com o Partido dos Trabalhadores, em 2005, e ingressa no Partido Socialismo e Liberdade. Desde que entrou no PSOL, a APS desenvolve papel dirigente e determinante dos rumos partidários. Durante toda essa jornada, um núcleo dirigente de militantes oriundos do MEP segue coeso. Em 2011, a APS sofre com uma divisão interna. Três grupos se formam: Rosa Zumbi e outros dois que se autodenominam APS. Curiosamente, é possível identificar que os militantes que vieram da OCDP permaneceram de um lado, tendo a Bahia como principal reduto, enquanto aqueles que vieram do MEP permaneceram de outro, tendo São Paulo como referência. Há nuances nessa toada. O que importa salientar é a linha sequencial daqueles que partilham da trajetória do MEP. O lado da APS desta tradição continuou exercendo hegemonia no PSOL. Em julho de 2019, diversos coletivos regionais, o Rosa Zumbi e a APS construíram uma nova organização: a Primavera Socialista. Nesse novo encontro entre mulheres e homens dispostos a procurar os caminhos da Revolução Brasileira, a marca do MEP se faz presente e atuante.

A Revolução Brasileira para o MEP, assim como assinalada por Caio Prado Júnior, é um processo permanente, ininterrupto e dinâmico. As palavras do historiador, abaixo, sobre o socialismo também definem o que MEP pensou e buscou aplicar. O mais notável é ver que essa tradição segue viva. A utopia socialista também.

"O socialismo, ao contrário do que frequentemente se vê afirmado, não constitui receita, um dogma, uma norma mais ou menos arbitrariamente escolhida segundo o gosto de reformadores, e a que se trataria de subordinar os fatos humanos e a organização da vida social [...]. O socialismo, como se pode concluir da observação e análise históricas deste último século decorrido, constitui um processo evolutivo que tem suas raízes no próprio capitalismo. É o capitalismo o principal responsável pelo socialismo cujas formas e forças propulsoras se geraram e desenvolveram precisamente no mesmo capitalismo. O socialismo é a resultante natural do capitalismo - que lhe prepara e abre o caminho, e que nele desemboca ao se desagregar"293.

293 Pericás, Luiz Bernardo. Caio Prado Júnior. Uma biografia política. São Paulo. Boitempo, 2016. Pg. 232. 


\title{
ANEXO: A ESTRATÉGIA ENCONTRA UMA SÍNTESE
}

O V Encontro Nacional do PT, ocorrido em 1987, é considerado por muitos o mais importante da história do partido ${ }^{294}$. Nele, pela primeira vez, a perspectiva estratégica socialista foi delineada. A participação da chama esquerda petista na elaboração da resolução sobre estratégia foi fundamental. O MCR, grupo fundado também pelo MEP, atuou nesse sentido. Mais do que isso, a organização assumiu para si a formulação. Pelo fato desta ter se materializado como síntese avançada da perspectiva socialista, consideramos importante reproduzir o seu conteúdo na íntegra, com o objetivo de dar fechamento a anos de reflexão acerca do que significa a construção do socialismo no Brasil. Segue o documento em anexo abaixo:

\section{OBJETIVO ESTRATÉGICO DO PT: SOCIALISMO 295}

\begin{abstract}
A conquista do socialismo e a construção de uma sociedade socialista no Brasil são os principais objetivos estratégicos do PT. Isso parece ser consenso, tanto em vista das resoluções aprovadas nas convenções nacionais, quanto da crescente pressão da militância para que definamos o tipo de socialismo que queremos e estabeleçamos as relações correspondentes entre nossa luta do dia-a-dia e a luta mais geral pelo socialismo. Na luta pelo socialismo, é preciso distinguir dois momentos estratégicos que, apesar de sua estreita relação de continuidade, são de natureza diferente. O primeiro diz respeito à tomada do poder político. O segundo refere-se à construção da sociedade socialista sobre as condições materiais, políticas etc. deixadas pelo capitalismo. Resoluções de Encontros e Congressos \& Programas de Governo
\end{abstract}

\section{A CONQUISTA DO SOCIALISMO}

Para extinguir o capitalismo e iniciar a construção da sociedade socialista, é necessário, em primeiro lugar, realizar uma mudança política radical; os trabalhadores precisam transformar-se em classe hegemônica e dominante no poder de Estado, acabando com o domínio político exercido pela burguesia. Não há qualquer exemplo histórico de uma classe que tenha transformado a sociedade sem colocar o poder político - Estado - a seu serviço.

Evidentemente, a construção da sociedade socialista não é algo totalmente novo e diferente em relação às formas de luta e de organização dos trabalhadores no seu dia-a-dia atual. Quando falamos que o socialismo e o poder se constroem na luta cotidiana, estamos nos referindo ao fato de que muitas das formas econômicas, sociais e políticas da construção

294 Secco, Lincoln. História do PT. Editora Ateliê Editorial. São Paulo, 2011. Pg. 50.

2950 trecho extraído encontra na Resolução Política do $V$ Encontro Nacional do PT: https://fpabramo.org.br/csbh/wp-content/uploads/sites/3/2017/04/07-resolucoespoliticas_0.pdf 
socialista surgirão, sem dúvida, da experiência da luta de classe contra o capitalismo. Muitas dessas formas que hoje não conseguem desenvolver-se em virtude da opressão capitalista, como as pequenas cooperativas, as compras comunitárias, as comunidades locais, os conselhos populares etc., provavelmente encontrarão um campo fértil para crescer nas novas condições socialistas. Mas as formas de organização fundamentais que surgem na luta cotidiana no interior da sociedade burguesa e que têm maior importância para a luta socialista são as que nascem da auto-organização dos trabalhadores, as formas de luta pelo controle operário nas fábricas (a partir da generalização das comissões de fábrica e empresa) e de controle popular nos bairros.

Essas formas embrionárias de poder proletário são escolas de autoorganização e participação política dos trabalhadores, que apontam no sentido da construção de um socialismo efetivamente democrático, em que o poder seja exercido pelos próprios trabalhadores e não em seu nome. Entretanto, essas experiências, em si, não resolvem a contradição do socialismo com o capitalismo. Mesmo porque, quanto mais amplas elas se tornam, maior é a resistência da burguesia dominante à sua existência. Repressão e concessões, em geral, se combinam para a burguesia continuar mantendo sob sua influência ideológica e política as grandes massas de trabalhadores e evitar o desenvolvimento das experiências populares e as mudanças. Para resolver as contradições sociais e políticas do sistema capitalista é fundamental que todas essas experiências de luta e de organização operárias, populares e democráticas sirvam como eixo de preparação e organização das classes trabalhadoras para a conquista do poder e a construção da nova sociedade.

Por isso, no enfrentamento cotidiano contra as táticas repressivas e/ou de concessões da burguesia, os trabalhadores terão que empregar táticas que retirem as massas da influência da burguesia e as levem a conquistar o poder. Nesse sentido, é preciso distinguir as atividades que partem da situação existente em cada momento e procuram fazer com que os trabalhadores tomem consciência da necessidade de conquista do poder das atividades que se destinam à conquista imediata do próprio poder.

Muitos companheiros não fazem essa distinção, não compreendem o processo de mediação que deve existir entre o momento atual, por exemplo, em que as grandes massas da população ainda não se convenceram de que é preciso acabar com o domínio político da burguesia, e o momento em que a situação se inverte e se torna possível colocar na ordem do dia a conquista imediata do poder. Dessa forma, seu discurso, pretensamente revolucionário, não é entendido pela população e pelos trabalhadores e, em vez de contribuir para a organização e a luta no sentido da conquista do poder e da construção socialista, a desorganizam e a transformam na luta de pequenos grupos conscientes e vanguardistas.

Por outro lado, companheiros que consideram inevitável a adoção de uma via revolucionária para a conquista do poder contrapõem essa escolha à tática dos movimentos sociais que lutam por reformas. Reforma e revolução são consideradas por eles como termos e práticas antagônicas. Entretanto, nenhum país que tenha feito revolução deixou de combinar essas lutas, dando maior ênfase a uma ou outra de acordo com a situação política concreta. A luta por reformas só se torna um erro quando ela acaba em si mesma. No entanto, quando ela serve para a educação das massas, através da própria experiência de luta, quando ela serve para demonstrar às grandes massas do povo que a consolidação, mesmo das reformas conquistadas, só é possível quando os trabalhadores estabelecem seu próprio poder, então ela serve à luta pelas transformações sociais e deve ser combinada com esta. 
Nesse sentido, para definir uma estratégia de luta pelo socialismo, não basta definir a via principal de luta, nem as táticas para a conquista do poder. É preciso, em especial, ter clareza sobre o inimigo ou inimigos principais contra quem nossa luta se dirige, as alianças de classes (estratégicas) para derrotar tais inimigos e o programa de transformações a ser implantado (que serve de base à mobilização popular e às alianças). 36 . Esclarecer tais problemas, na realidade, não é algo que possa ser decidido arbitrariamente. Depende do conhecimento da estrutura social brasileira, das contradições que existem nessa estrutura e do grau que tais contradições alcançaram como resultado de todo um processo histórico de lutas. Isso inclui o conhecimento do papel e da força do Estado burguês e do grau de desenvolvimento da cultura política dos trabalhadores e, em particular, o conhecimento das tendências do movimento de cada um desses aspectos e de sua resultante.

Existe um certo consenso, entre os militantes e filiados do PT, de que a burguesia é a inimiga principal das mudanças sociais e dos trabalhadores. É uma certeza intuitiva, que resulta da experiência concreta de enfrentamento com a burguesia. $O$ problema, porém, não é esse. $O$ problema reside no fato de que, por uma insuficiente análise das classes existentes na sociedade brasileira, muitos companheiros colocam no campo da burguesia parcelas significativas de pequenos e microempresários urbanos e rurais e mesmo as camadas assalariadas que não trabalham diretamente na produção fabril ou agrícola. Com isso, não levam em conta que tais camadas possuem profundas contradições com o capital e, por isso, podem se incorporar à luta por transformações sociais no sentido socialista.

Por outro lado, ao tomar a classe burguesa como inimiga principal, estratégica, muitos militantes são levados a se oporem a que se aproveitem as contradições momentâneas entre os diversos setores da burguesia. Colocam-se contra qualquer aliança política, tática ou pontual, com alguns desses setores. Mas o que importa aqui é que tais posturas são reflexos também de um conhecimento insuficiente ou mesmo de um desconhecimento das contradições internas que movem as classes em sua luta, e que muitas vezes podem colocar em oposição diferentes setores da própria burguesia. Esse conhecimento insuficiente é uma das razões principais que explicam por que o PT, como um todo, ainda não avançou suficientemente nas definições estratégicas.

Para que o processo de definições estratégicas do PT conte com a participação democrática dos militantes e filiados, é imprescindível que o Partido organize o estudo e o debate sobre as classes e as contradições de classes da sociedade brasileira; o papel da pequena burguesia urbana e rural; a definição dos pontos programáticos que garantam a atração dos setores sociais que têm contradições com a burguesia; a via principal de transformação social e as táticas a serem empregadas para realizá-la; e a relação entre a estratégia do Partido e as diversas táticas para implementá-la. Esses são problemas colocados pelo atual avanço da luta de classes no Brasil, que devem ser tratados adequadamente. Tratá-los não é uma tarefa de alguns intelectuais e dirigentes, ou mesmo de uma corrente política dentro do Partido. Essa é uma tarefa que deve envolver o conjunto da militância petista.

\section{A CONSTRUÇÃO DO SOCIALISMO}

O desenvolvimento desigual e desequilibrado do capitalismo no Brasil coloca diante dos trabalhadores uma série de questões relacionadas com a construção socialista após a conquista do poder. Questões que aparecem, desde já, em função das propostas programáticas do PT e das alianças estratégicas que devem ser realizadas para obter a hegemonia contra a burguesia. Evidentemente, o desenvolvimento intenso do capitalismo nos 
últimos 30 anos colocou bases firmes para o estabelecimento de um sólido setor socialista na economia. Nas grandes cooperativas agroindustriais capitalistas, grandes empresas comerciais e de serviços e bancos, a socialização com a apropriação privada dos resultados da produção permite sua transformação imediata em empresas socialistas, estatais ou coletivas.

Por outro lado, subsiste no Brasil um vasto setor que, embora seja em ampla medida subordinado ao grande capital, procura desenvolver-se com absorção de mão-de-obra e com atendimento a uma série enorme de bens de serviços considerados secundários e de baixa rentabilidade. Constituído por milhões de pequenas empresas, pequenos negócios, serviços e autônomos, desempenha um papel econômico de grande importância no atual sistema capitalista brasileiro, o que obriga a um processo permanente de destruição e recriação desse setor - papel que deve continuar desempenhando mesmo depois de iniciarmos a construção socialista no Brasil. Desse modo, um dos aspectos-chave do processo de construção socialista, mesmo tendo como a parte essencial da economia o seu setor socialista, estatal ou coletivo, consiste em conhecer a capacidade do Estado em atender às reais necessidades sociais e adaptar uma política econômica que complemente, de forma integral, aquela capacidade para isso.

O único caminho, até hoje, consiste em permitir que a pequena economia mercantil ainda se desenvolva em uma certa escala, e que seu próprio desenvolvimento natural e contraditório conduza à concentração e centralização econômica e sua transformação socialista por meios administrativos. A pequena produção serve para que a sociedade desenvolva suas forças produtivas, contribua para que não haja escassez de bens e serviços e permita incorporar ao trabalho o conjunto da população economicamente ativa, sem prejudicar a eficiência das empresas socialistas nem a constante redução da jornada de trabalho. Essa política de desenvolvimento da capacidade produtiva da sociedade, utilizando todas as forças econômicas, é a base da aliança dos trabalhadores assalariados com a pequena burguesia urbana e rural. Essa aliança é, pois, uma questão estratégica, referente tanto à destruição do capitalismo quanto à construção do socialismo.

Evidentemente, essa é uma contradição própria do desenvolvimento das classes no Brasil, do mesmo modo que é impossível, dadas as atuais condições, que o socialismo possa extinguir todas as classes de imediato. $O$ processo de construção socialista para alcançar a almejada sociedade igualitária, sem classes, sem opressão e dominação, vai enfrentar, durante certo tempo, a exigência de diferentes desigualdades, como herança do capitalismo. E vai obrigar a agir, não no sentido de extinguir administrativamente as desigualdades, mas de evitar que elas se polarizem e se tornem antagônicas em relação ao socialismo. Tais contradições no terreno econômico e social da construção socialista geram diferentes contradições no terreno da política. Isso nos remete, basicamente, para a relação do socialismo com a democracia. Socialismo e democracia 44. A permanência de diferentes classes e camadas sociais no processo de construção socialista, por um tempo difícil de prever de antemão, coloca para nós a necessidade de reconhecer a existência de diferentes expressões políticas na sociedade socialista. É fundamental compreender que, mesmo que não se concretizem ingerências externas à coexistência de diferentes partidos e associações políticas, assim como de diferentes propostas para a construção socialista, torna extremamente aguçada a disputa política, disputa que pode polarizar-se e ter consequências graves, se não forem tratadas como merecem, ou seja, disputas que, na sua maior parte, estão dentro de um mesmo campo socialista, e não disputas entre inimigos.

O fato de que na Nicarágua, a partir do programa da Frente Sandinista de Libertação Nacional (FSLN), apesar do cerco imperialista e da oposição militar dos contras, existia 
liberdade sindical, de organização partidária, de comissões de empresa, das milícias, dos comitês populares e que, inclusive, foram realizadas eleições democráticas, indica a atualidade da relação entre a luta pelo socialismo e a democracia. Longe de a democracia ser uma concessão, ela é parte componente de uma revolução viva e fator de combate contra a burocratização.

A ausência de democracia, do direito à livre organização dos trabalhadores, é contraditória com o socialismo pelo qual lutamos. Ainda mais quando sabemos, a partir de várias experiências históricas, que essa ausência foi alçada quase que a um princípio permanente, cujas consequências podem ser vistas, hoje, num certo impasse que vivem vários países que fizeram a revolução e que está na base, por exemplo, da luta dos trabalhadores poloneses em torno do Solidariedade, que o PT tem apoiado. Solidário com as lutas dos povos por sua libertação, o PT defende o rompimento de relação com o regime racista da África do Sul e com a ditadura do general Pinochet, do Chile.

Além disso, é preciso levar em conta que a sociedade brasileira já foi capaz de desenvolver razoavelmente algumas organizações da sociedade civil, que jogam determinado peso na determinação das políticas do Estado. E de que o Estado brasileiro, embora tenha se reforçado muito, contando com modernos aparelhos coercitivos (Forças Armadas, Serviços de Informação etc.) e de concessões e participação (Legislativos, assistência social, centros comunitários etc.) não tem condições de se fechar completamente à participação das classes subalternas em seu interior. Ao contrário, a própria magnitude do Estado moderno brasileiro só é viável se a burguesia for buscar, na massa das outras classes, os funcionários do Estado. E se, para conseguir consenso e legitimidade para esse mesmo Estado, for obrigada a abrir, pelo menos formalmente, o Estado à disputa das diversas classes.

Na sociedade civil ocorre algo idêntico. A burguesia construiu organizações sólidas (Fiesp, CNA, CNI etc.), que atuam tanto para manter a hegemonia de sua classe sobre as outras quanto para manter o domínio do aparelho do Estado. Em contraposição a isso, tanto os assalariados quanto as camadas médias da população também criaram organizações de sociedade civil que participam daquela disputa pela hegemonia e pelo poder. Em grande medida, o movimento contraditório dessas diversas organizações da sociedade civil (e também dentro delas) em relação ao Estado e a disputa no interior do próprio Estado causa os avanços e recuos da democracia, sua ampliação e retração.

O PT rejeita a concepção burocrática do socialismo, a visão do partido único, por considerar incorreta a ideia de que cada classe social é representada por um único partido, e que outros partidos existentes na sociedade que emergir de uma revolução serão necessariamente partidos que representarão interesses de classes diferentes dos da classe trabalhadora. Seria ingenuidade supor que, conquistado o poder pelos trabalhadores, essa situação estaria resolvida. Embora a liquidação da burguesia, como classe, compreenda também a liquidação de suas organizações civis e de seu Estado, grande parte das organizações da sociedade civil hoje existentes continuarão presentes na nova sociedade e não podem (nem devem) ser abolidas por decreto. Isso significa que no processo de construção do socialismo deverão existir não só diversos partidos e diversas organizações da sociedade civil, como também que as relações de organizações com o poder socialista serão não só de colaboração e participação, mas também de oposição.

Nessas condições, o Estado socialista terá de desenvolver esforços tanto para estabelecer uma legalidade nova, democraticamente construída e válida para todos, como manter e/ou criar 
mecanismos de participação e consulta popular nos mais diferentes níveis e nas relações entre tais níveis. A participação operária e popular na gestão das fábricas, das granjas e fazendas, dos bairros e conjuntos residenciais, das comunidades, vilas e distritos é de suma importância para o funcionamento de uma extensa democracia de base. Entretanto, talvez essa não seja a questão-chave da democracia no socialismo. Os problemas mais sérios vão aparecer nas relações entre os mecanismos democráticos de participação e consulta na base com os mecanismos de participação e consulta nos níveis intermediários e superiores do poder.

O projeto socialista pelo qual lutamos, de outro lado, deve incorporar as perspectivas colocadas pelos diferentes movimentos sociais que combatem opressões específicas, como os das mulheres, dos negros, dos jovens e dos homossexuais, e suas expressões ideológicas, em particular o feminismo, indispensáveis para golpear importantes pilares da dominação exercida pela burguesia e engajar, em profundidade, a maioria da população brasileira num processo de transformação revolucionária. Deve, também, integrar movimentos de âmbitos culturais nacionais ou ambientais, que procuram responder às agressões que o capitalismo realiza contra a população e o meio ambiente, movimentos anticapitalistas e progressistas, que sensibilizam parcelas crescentes do povo. Deve, ainda, incorporar o questionamento de outros mecanismos vitais para a reprodução da dominação de classe. A incorporação dessas lutas no projeto político proletário, desde hoje, permite barrar o avanço da burguesia, que procura esvaziá-las do seu conteúdo crítico e questionador de instituições e valores da ordem burguesa.

Sem um tratamento correto dessas questões, no sentido de manter abertos os canais de participação das massas trabalhadoras no poder de Estado e a observância dos direitos individuais dos membros da sociedade e, ao mesmo tempo, garantir a existência do Estado socialista como instrumento fundamental para a construção socialista, será impossível transformar as liberdades políticas e a democracia formais, próprias do capitalismo, nas liberdades e na democracia real que deve ser própria do socialismo. 
ANISTIA PARA PRESOS E pERSEGUIDOS POI.fticos :

Os punhos cerrados ficarão em nossa memōria, e amanhā, mais do que hoje. serão un pesadelo para os ditadores e seus siaquzes

Trecho da Carza dos 10 Conpanhelros condenados. acusados de pertencere ao Mbviento pola Enancipacío do Proletariado. 12 de Dezembro de 1970

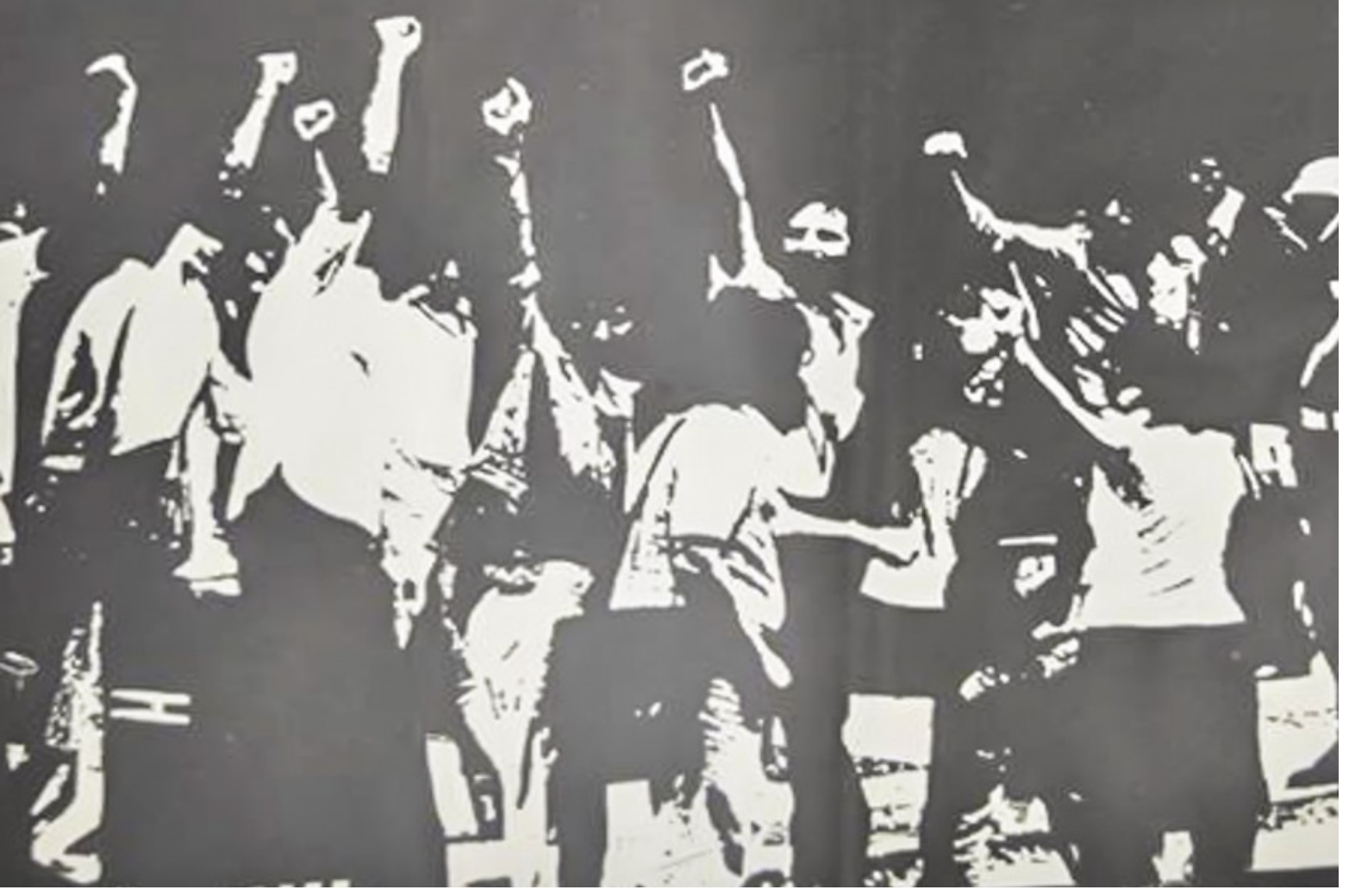

Ilustração 1: cartaz do Comitê Brasileiro pela Anistia 


\section{ORGANOGRAMA DAS ORGANIZAÇÕES DE ESQUERDA}

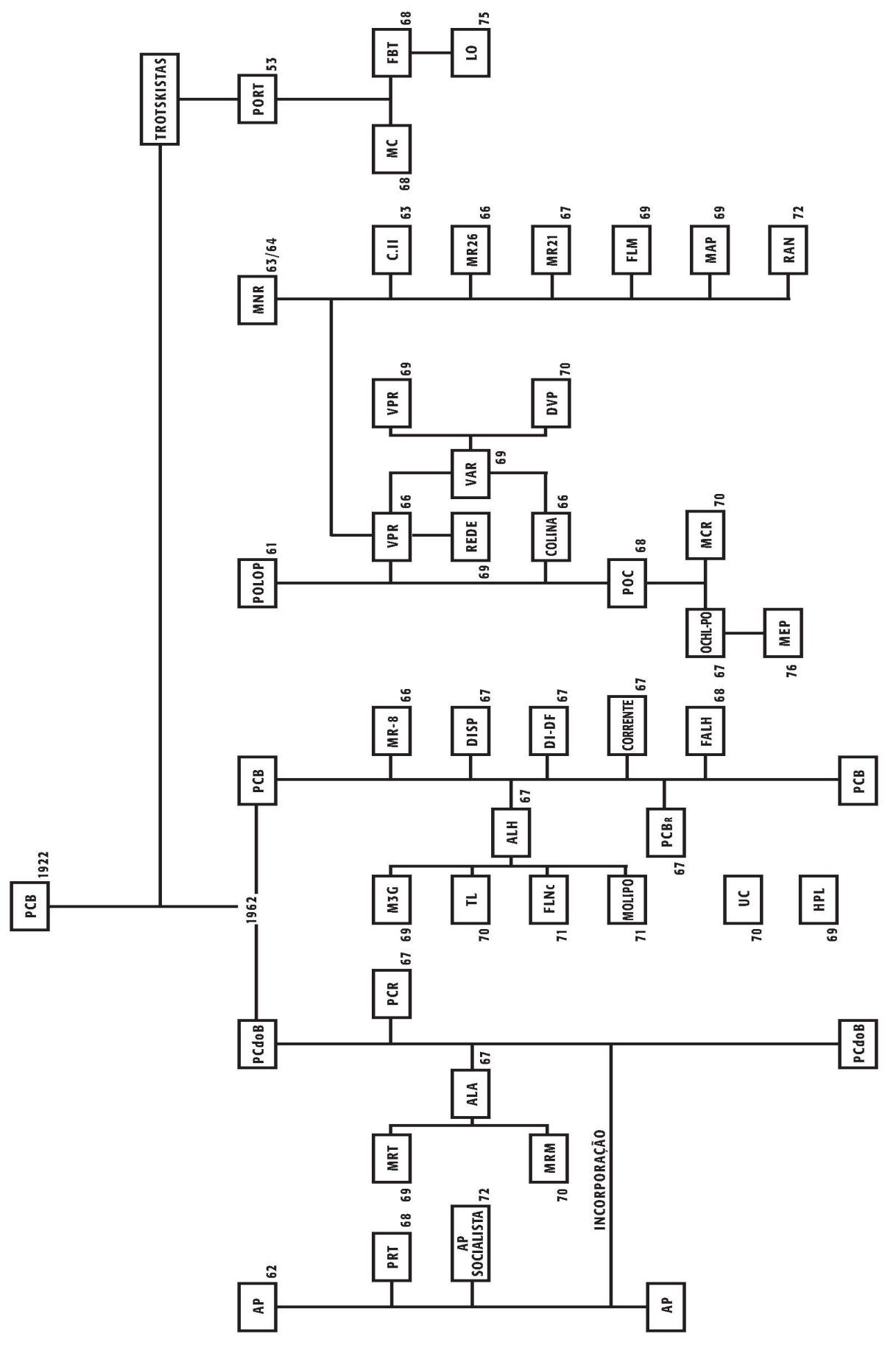

lustração 2: organograma das organizações de esquerda 


\section{JORNAL NOVA LUTA}

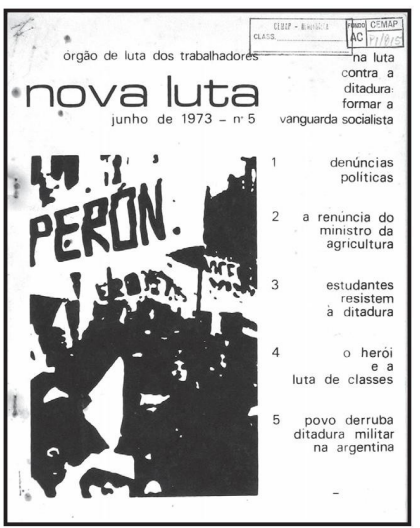

$1973 \cdot 06 \cdot n^{0} 05$

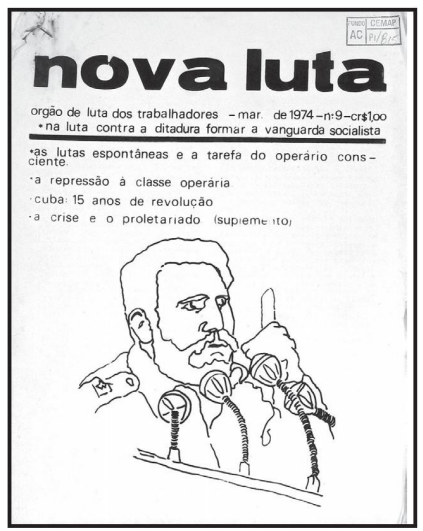

$1974 \cdot 03 \cdot n^{0} 09$

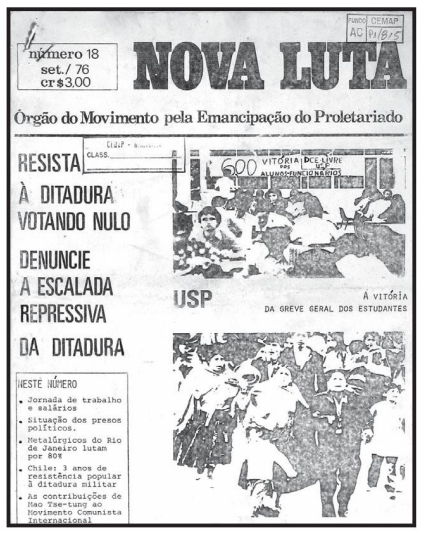

$1976 \cdot 09 \cdot n^{0} 18$

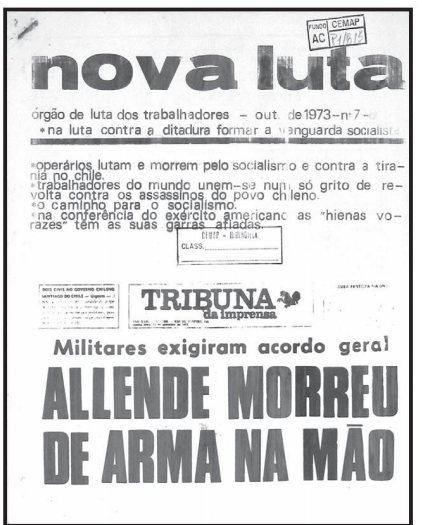

$1973 \cdot 10 \cdot n^{0} 07$

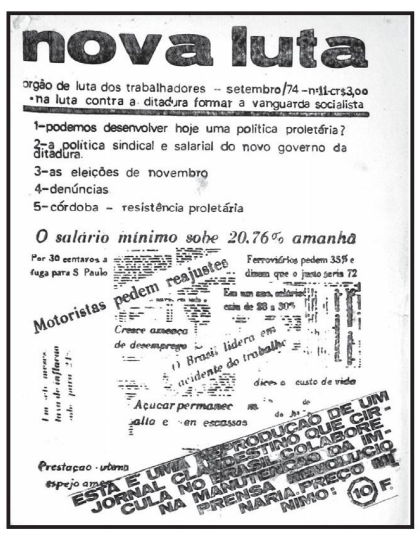

$1973 \cdot 09 \cdot n^{0} 11$

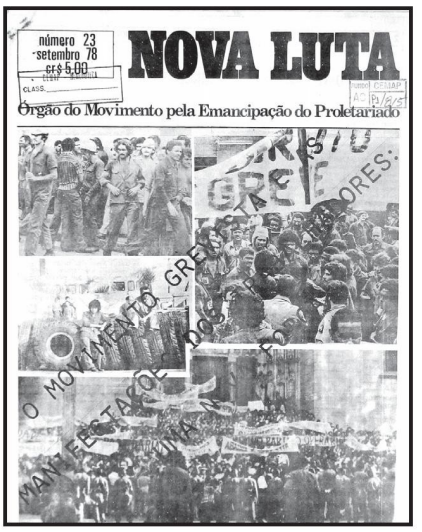

$1978 \cdot 09 \cdot n^{0} 23$

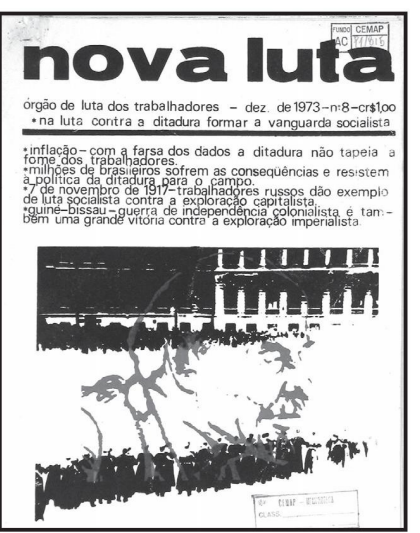

$1973 \cdot 12 \cdot n^{0} 08$

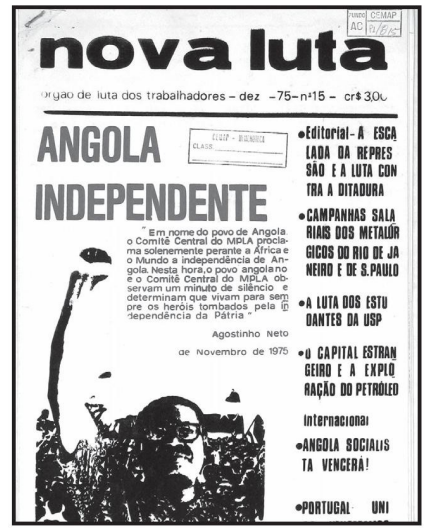

$1975 \cdot 12 \cdot n^{0} 15$

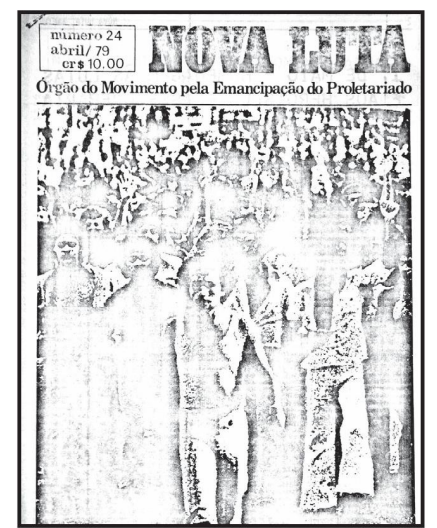

$1979 \cdot 04 \cdot n^{0} 24$

Ilustração 3: exemplares do jornal Nova Luta 


\section{JORNAL COMPANHEIRO}
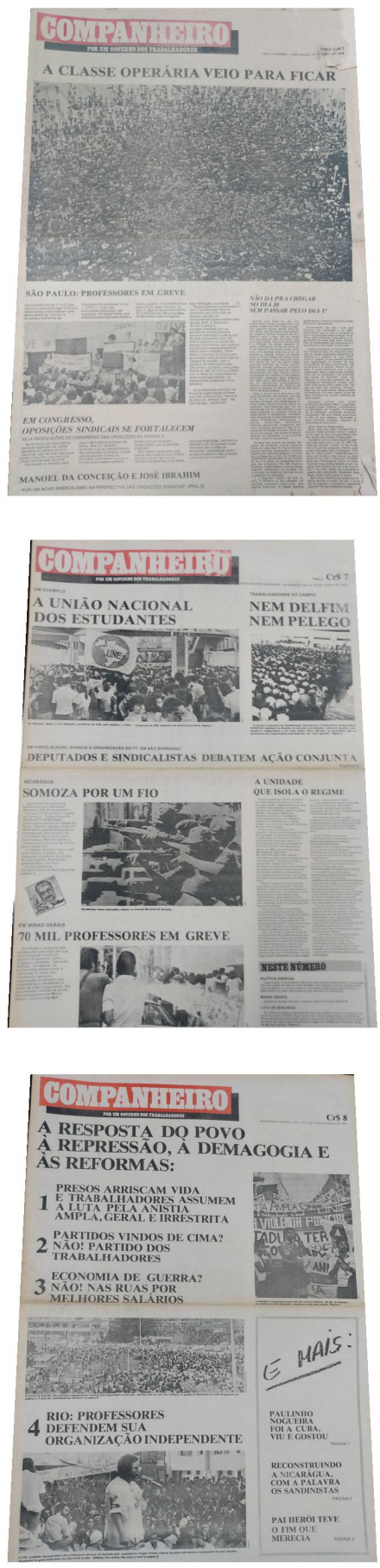
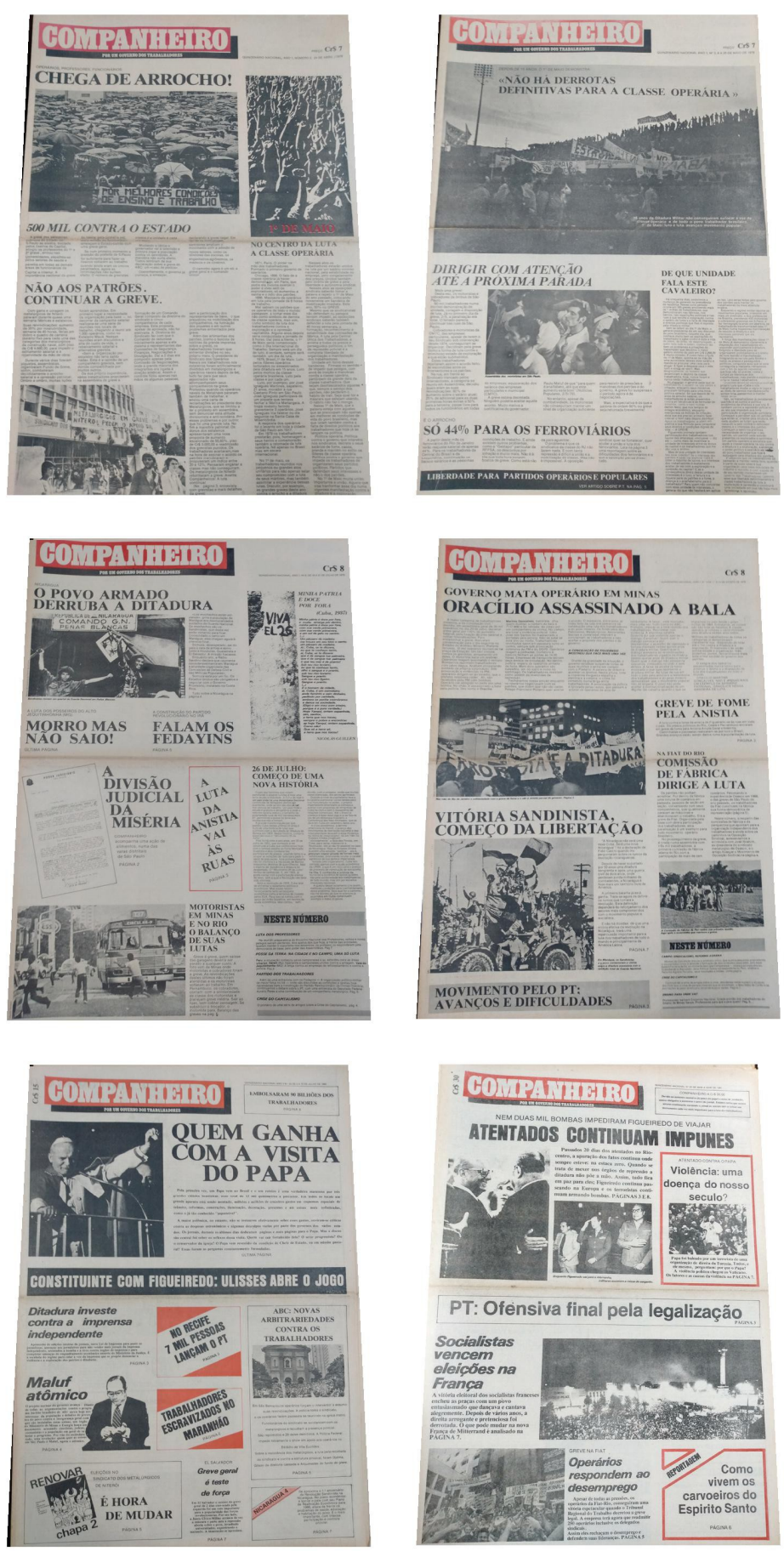


\section{REVISTA TEORIA e PÁtica}
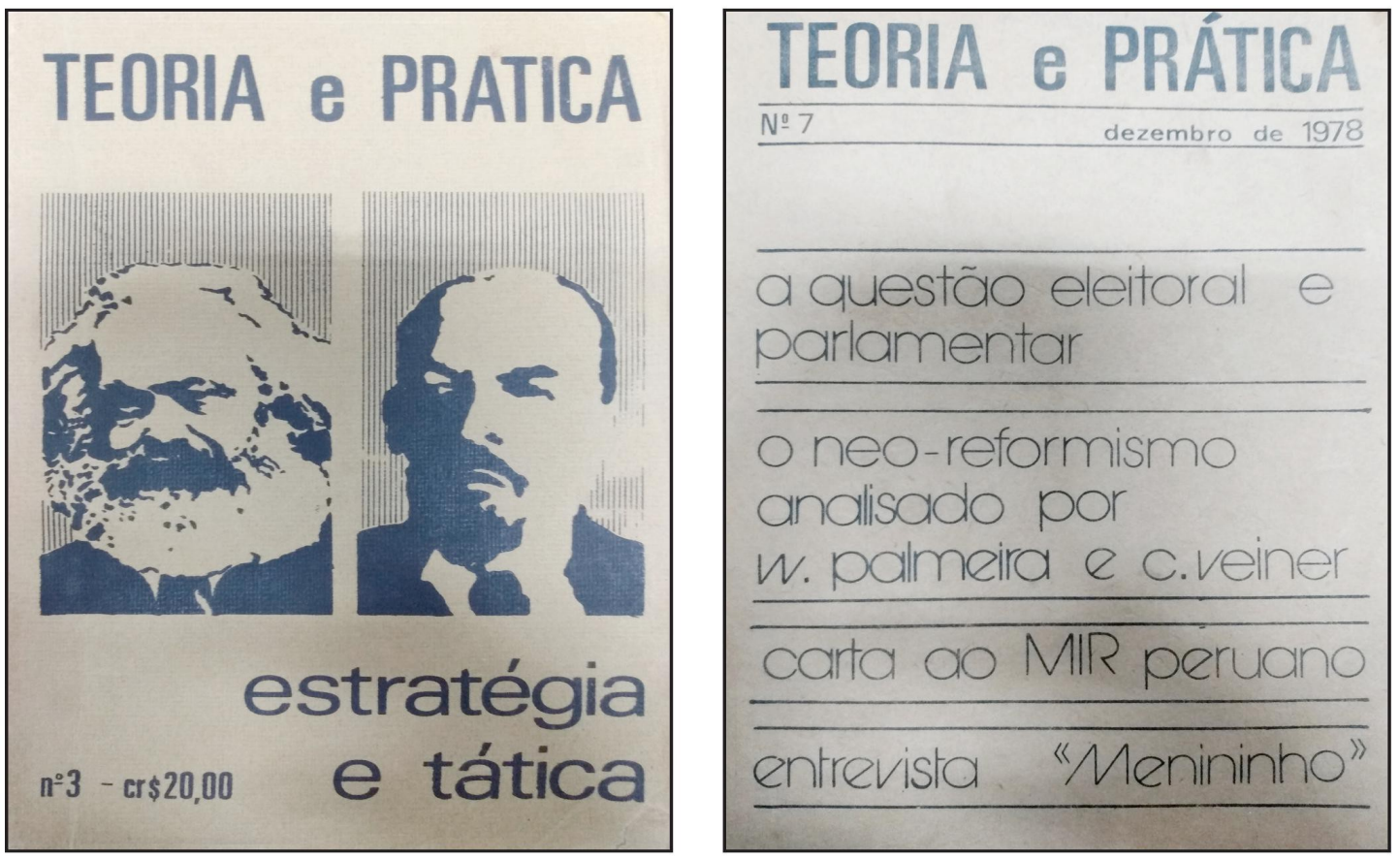

Ilustração 5: exemplares da revista Teoria e Prática 


\section{FONTES E ACERVOS CONSULTADOS}

\section{Arquivos consultados}

Arquivo Público do Estado do Rio de Janeiro

Centro de Documentação e Memória da UNESP

Centro Sérgio Buarque de Holanda: documentação e memória política da Fundação Perseu Abramo

\section{Acervos digitais}

Brasil Nunca Mais: http://bnmdigital.mpf.mp.br/pt-br/

Centro de Pesquisa e Documentação de História Contemporânea no Brasil: https://cpdoc.fgv.br/acervo/arquivospessoais/base

Memórias Reveladas: http://memoriasreveladas.gov.br/

https://bibliotecadigital.indh.cl/bitstream/handle/123456789/600/Informe-Valechll.pdf? sequence $=5$

\section{Lista de sites}

https://www.marxists.org/portugues/marighella/1969/08/sobre.htm. www.amauta.lahaine.org https://www.ifch.unicamp.br/ojs/index.php/ael/article/view/2427/1839 http://www.filosofia.org/rev/pch/1967/n07p159.htm http://g1.globo.com/politica/noticia/2014/09/cnv-critica-manifesto-em-que-generais-senegam-pedir-desculpas.html 
http://www.folhapolitica.org/2014/03/general-diz-que-militares-estao.html.

http://www.snh2011.anpuh.org/resources/rj/Anais/2006/conferencias/Natalia\%20de $\% 20$ Souza\%20Bastos.pdf

http://www.uel.br/eventos/gpp/pages/arquivos/8.AylaCamargo.pdf

http://www.stf.jus.br/portal/cms/verNoticiaDetalhe.asp?idConteudo=125515

https://docs.google.com/file/d/0BzFjYS2mqlc9RmE4MWk2S1RoOFk/edit

http://www.historia.uff.br/stricto/teses/Tese-2011_Kenia_Miranda.pdf

http://www.bibliotecadigital.ufmg.br/dspace/bitstream/handle/1843/HJPB-

6QJQTY/2000000104.pdf?sequence=1

http://sindutemg.org.br/institucional/nossa-historia/

https://fpabramo.org.br/csbh/wp-content/uploads/sites/3/2017/04/07-

resolucoespoliticas_0.pdf

\section{Lista de jornais}

Companheiro

Estado de São Paulo

Folha de São Paulo

O Globo

Movimento 


\section{Lista de entrevistados}

Esther Kuperman

Inês Paes

Ivan Valente

Jorge Paes

Luiz Arnaldo Dias Campos

Luiz Araújo

Maria Célia Fernandes

Miguel Carvalho

Nilton Santos

Vera Colson Valente 


\section{BIBLIOGRAFIA}

Abreu, Maria Gonçalves de. Feminismo no exílio: Circulo Brasileiro de Mulheres em Paris. In: BRASIL. Secretaria Especial de Políticas para as Mulheres. $1^{\circ}$ Prêmio "Construindo a Igualdade de Gênero": redações e trabalhos científicos monográficos premiados. Brasília, 2006, p. 103-105.

Aggio, Alberto. Democracia e Socialismo, A experiência chilena. Editora Annablume. São Paulo, 2002.

Antunes, Ricardo. Os comunistas no Brasil: as repercussões do VI Congresso da Internacional Comunista e a primeira inversão stalinista no Partido Comunista do Brasil (PCB). Pg. 16. O texto se encontra no portal do IFCH: https://www.ifch.unicamp.br/ojs/index.php/ael/article/view/2427/1839.

Araújo, Braz José. A imprensa alternativa e a Conclat. In: Frederico, Celso. A esquerda e o movimento operário (196401984) - a reconstrução. Vol. 3. Editora Oficina de Livros. Belo Horizonte, 1991.

Azevedo, Carlos. Jornal Movimento. Uma reportagem. Editora Manifesto. Belo Horizonte (MG). 2011.

Bastos, Natália de Souza. Círculo Brasileiro de Mulheres Brasileiras em Paris: uma experiência feminista no Exílio. In: Encontro Regional de História, 12., 2006, Rio de Janeiro. 2006.

http://www.snh2011.anpuh.org/resources/rj/Anais/2006/conferencias/Natalia\%20de \%20Souza\%20Bastos.pdf

Brito, Ângela Neves-Xavier de; STANLEY, Charlotte. Brazilian women in exile: the quest for an identity. Latin American Perspectives, v. 13, n. 2, p. 58-80, 1986.

Bielschowsky, Ricardo. Pensamento Econômico Brasileiro - o ciclo ideológico do desenvolvimento. Editora Contraponto, 1988, Rio de Janeiro.

Bresser-Pereira, As três interpretações da dependência. Perspectivas, v.38, p. 
17-48, jul/dez. 2000. São Paulo.

Burke, Peter (org). A história dos acontecimentos e o renascimento da narrativa. In: A escrita da história. Novas Perspectivas. Editora Unesp. São Paulo, 2011.

Carmargo, Ayla. Nas origens do movimento feminista revisitada no Brasil: o círculo de mulheres de Paris. Anais do I Simpósio sobre Estudos de Gênero e Políticas $\quad$ Públicas, $\quad$ ISSN 2177-8248. Ver em: http://www.uel.br/eventos/gpp/pages/arquivos/8.AylaCamargo.pdf.

Cardoso, Fernando Henrique. A dependência revisitada. Revista Latinoamericana de Ciência Sociales, FLACSO (4), dezembro de 1972.

Conceição, Gilmar Henrique da. Partidos Políticos e Educação: a extremaesquerda brasileira e concepção de partido como agente educativo. Cascavel. Ediunioeste, 2000.

Coutinho, Carlos Nelson. Gramsci. Um estudo acerca de seu pensamento político. Editora Civilização Brasileira. Rio de Janeiro, 2007.

Debray, Regis. Revolução na Revolução. São Paulo. Centro Editorial Latino Americano, 1985.

Ferreira, Maria Nazareth. Imprensa operária no Brasil. São Paulo. Ática, 1988.

Figueiredo, Carlos. Palavras aos petistas: crônica do 13 de outubro. Belo Horizonte, Editora Jequitinhonhense, 1985.

Fragoso, Heleno. Advocacia da liberdade. A defesa nos processos políticos. Rio de Janeiro, Forense, 1984.

Frank, André Gunder. El desarrollo Del subdesarrollo. Pensamiento Crítico, Habana, $N^{\circ} 7$, agosto de 1967.

Frederico, Celso (Org.). A esquerda e o movimento operário (1964-85). Belo 
Horizonte, Oficina de Livros, 1991.

Gorender, Jacob. Combate nas trevas. São Paulo. Expressão Popular e Fundação Perseu Abramo, 2013.

Harnecker, Marta. O sonho era possível: a história do Partido dos Trabalhadores narrada por seus protagonistas. São Paulo. Casa América Livre/ MEPLA, 1994.

Hobsbawm, Eric. Sobre História. São Paulo. Editora Companhia das Letra, 1997.

Kucinski, Bernardo. Jornalistas e revolucionários: no tempo da esquerda alternativa. São Paulo, Scritta, 1991.

Macedo, Luiz Alberto Castro de. Negociação, conflito e democracia. Porto Alegre. Feplam, 1989.

Magalhães, Mário. Marighella, o guerrilheiro que incendiou o mundo. São Paulo. Companhia das Letras, 2012.

Marini, Ruy Mauro. Dialética de La dependencia. In: htttp//: www.amauta.lahaine.org

Mattos, Marcelo Badaró. Em busca da revolução socialista. A trajetória da POLOP (1961-1967). In: Ridenti, Marcelo; Reis Filho, Daniel Aarão (org.). História do Marxismo no Brasil - partidos e organizações dos anos 1920 aos 1960, V 5. Campinas. Unicamp, 2002.

Miranda, Kenia. As lutas dos trabalhadores da Educação: do "novo sindicalismo" à ruptura com a CUT. Tese apresentada ao Programa de PósGraduação em História como requisito para obtenção do Grau de Doutor em História. Área de concentração em História Social e Política.

Moraes, Dênis. A esquerda e o golpe de 1964. Expressão Popular. São Paulo, 2014. 
Moraes, João Quartim. Concepções comunistas do Brasil democrático: esperanças e crispações (1944-1954). In: Moraes, João Quartim (Org.). História do Marxismo no Brasil. Teorias. Interpretações, V3. Campinas. Unicamp, 1998.

Menegozzo, Carlos Henrique Metidieri. Fração Bolchevique (1970-1976). São Paulo, fev. 2008 (mimeo).

Menegozzo, Carlos Henrique Metidieri. História da APS: quadro histórico (1960-2005). São Paulo, jun. 2007 (mimeo).

Napolitano, Marcos. História do Regime Militar Brasleiro. São Paulo. Contexto, 2014.

Napolitano, Marcos. Recordar é vencer: as dinâmicas e vicissitudes da construção da memória sobre o regime militar brasileiro. In: Revista Antíteses. V.8, N 15ESP (2015).

Olinda, Ercília Maria B .de. A dimensão política do partido político. Fortaleza. Expressão, 1991.

Oliveira, Francisco. Crítica à razão dualista. Ornitorrinco. São Paulo. Boitempo, 2003.

Oliveira, Wellington. A trajetória histórica do movimento docente de Minas Gerais: da UTE ao Sind-UTE. Tese apresentada ao programa de Pós-Graduação em Educação na linha de pesquisa Movimentos Sociais da Faculdade de Educação da UFMG como requisito parcial à obtenção do título de doutor em Educação. Pgs. 66; 69; 92. Disponível em (http://www.bibliotecadigital.ufmg.br/dspace/bitstream/handle/1843/HJPB6QJQTY/2000000104.pdf?sequence=1)

Paula, Ricardo Pires. Uma História de Apeoesp (1945-1989): entre o sacerdócio e a contestação. Editora Paco Editorial. Jundiaí, 2011. Pg. 125.

Pericás, Luiz Bernardo. Caio Prado Júnior. Uma biografia política. São Paulo. Boitempo, 2016. 
Pericás, Luiz Bernardo; Secco, Lincoln (org.). Intérpretes do Brasil. Clássicos, rebeldes e renegados. São Paulo. Boitempo, 2014.

Ridenti, Marcelo. Brasilidade Revolucionária. São Paulo. Unesp, 2010.

Ridenti, Marcelo. O fantasma da revolução brasileira. São Paulo. UNESP, 2010.

Reis Filho e Ferreira de Sá. Imagens da Revolução. Documentos Políticos das organizações Clandestinas de esquerda dos anos 1961-1971. São Paulo. Expressão Popular, 2006.

Reis, Daniel Aarão (org.). Modernização, ditadura e democracia 1964-2010. São Paulo. Objetiva, 2014.

Rollemberg, Denise. Exílio: entre raízes e radares. São Paulo. Record, 1999.

Santos, Nilton. El Salvador: tendo a frente um povo em armas. Rio de Janeiro. Edições Mário Pedrosa, 1982.

Santos, Raimundo. Crise e pensamento moderno no PCB dos anos 50. In: Moraes, João Quartim; Reis, Daniel Aarão (org.). História do Marxismo no Brasil. Impacto das Revoluções, V1. Campinas. Unicamp, 2003.

Silva, Antonio Ozai da. História das tendências no Brasil: origens, cisões e propostas. São Paulo. DAG, 1986.

Singer, Paul. O processo econômico. In: Modernização, ditadura e democracia (1964-2010). Org. Daniel Aarão Reis. Editoras Funación Mapfre e Objetiva. São Paulo, 2014.

Secco, Lincoln. História do PT. Cotia. Ateliê Editorial, 2011.

Vinhas, Moisés. O Partidão. A luta por um partido de massas (1922-1974). São Paulo. Hucitec, 1982. 
